\title{
Building States, Undermining Public Order? Security Sector Reform in Pluralist Public Order Regimes
}

\author{
by
}

Gaëlle Rivard Piché

A thesis submitted to the Faculty of Graduate and Postdoctoral Affairs in partial fulfillment of the requirements for the degree of

Doctor in Philosophy

in

International Affairs

Carleton University

Ottawa, Ontario

C) 2017, Gaëlle Rivard Piché 


\section{Abstract}

Since the Cold War and especially following the attacks of September 2001, security sector reform has become a key component of the state-building project targeting unstable, fragile states. Yet, despite its popularity with donors and other international stakeholders, SSR has often failed to fulfill its overarching objective: reduce violence and make people safer. SSR success is unclear at best, as suggested by Afghanistan and Iraq, but also Haiti and El Salvador. In this dissertation, I argue that SSR falls short of its promises because it often fails to acknowledge the complex environment in which it takes place. Indeed, SSR tends to remain state-centric, targeting only public security and justice institutions and their formal role in the production of public order. Yet, in fragile states, the State does not hold the monopoly on violence, and its capacity to produce public order and provide security remains limited. Where the State is unable to do so, other actors have often emerged to produce public order and claim control over the means of violence.

To better understand the impact of SSR on these complex environments, I introduce the public order regime framework to map out systematically how public order is produced by state and non-state actors through more or less formal means in those complex polities. Looking more closely at SSR programs in Haiti and El Salvador, I find that the effect of SSR on pluralist public order regimes varies based on the strategy chosen to deal with non-state coercive actors and informal public ordering. Where nonstate actors have a strong incentive to claim control on the means of violence, statecentric SSR tend to be disruptive and can backfire, increasing rather than reducing violence. When the structure of the regime is taken into consideration by SSR however, 
the disruptive consequences of these reforms can be mitigated. Based on those results, I call for a more pragmatic approach to SSR that departs from Western normative assumptions, and is anchored in a finer understanding of the complex composition of governance structures in fragile states. 


\section{Acknowledgements}

It takes a village to raise a child, and a tribe to write a dissertation. First and foremost, I want to thank Jean Daudelin, without whom this project would never have existed. He stood by me each step of the way, through the good and the bad. Someone once told me I should be very careful when choosing my doctoral supervisor, as this relationship would shape my entire experience through the Ph.D. I chose well. I also want to thank my two advisors, David Mendeloff and Desmond Arias, who provided me with extensive and much appreciated feedback and advices, from the proposal up to the defence.

Second, this dissertation was made possible because so many people in Haiti and El Salvador believed in the project, and gracefully shared their time and their story with me. I am obliged to Jeanne, Adrian, Nelson, Rafa, Mariam, Augusto, Jane, Mike, and Tristan, as well as many others I cannot name here for security and confidentiality purposes. Financial support from the Social Science and Humanities Research Council, the Department of National Defence, the International Development Research Centre, and Fulbright Canada gave depth and breath to this dissertation.

Finally, thank you to Stéfanie von Hlatky and Marie-Joëlle Zahar who convinced me to undertake doctoral studies, offered me continuous support through the years, and became close friends I value dearly and who inspire me daily. Simon Langlois-Bertrand, my friend and first reader, has been an incredible source of ideas and feedback at every stage of the project. Of course, nothing would have been possible without the support and the love of my parents who watched me embark on this crazy adventure seven years ago. And Lénie, this one is for you. 


\section{Table of Contents}

Abstract............................................................................................................... ii

Acknowledgements ....................................................................................... iv

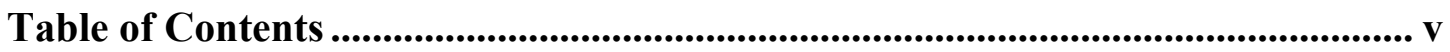

List of Tables ....................................................................................................... xiii

List of Figures.................................................................................................................. xiv

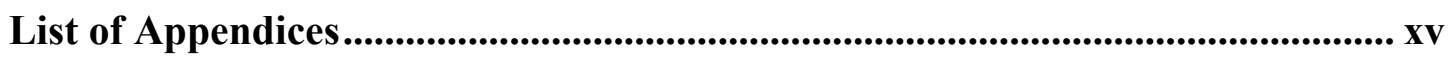

1 Chapter: Security Sector Reform and Public Order Regimes ........................... 1

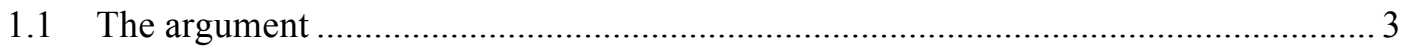

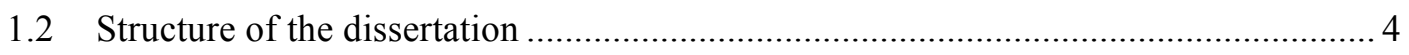

2 Chapter: A State of the Debate on Security Sector Reform ........................... 7

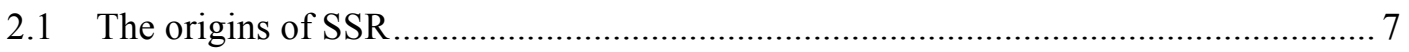

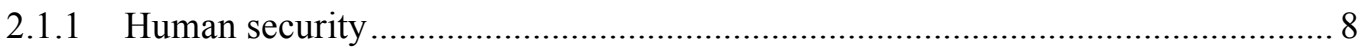

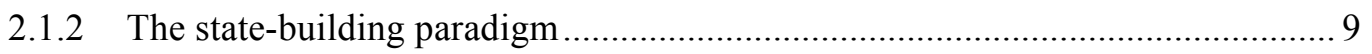

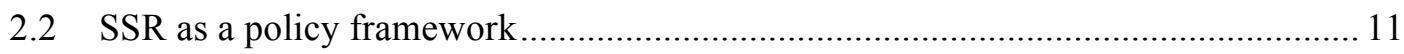

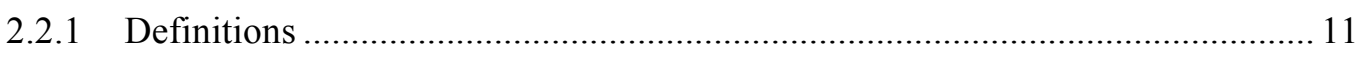

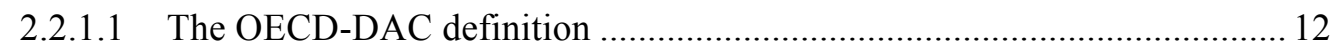

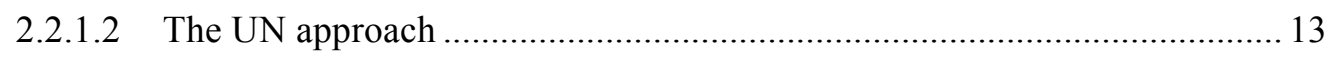

2.2.2 Non-state actors and informal arrangements ............................................... 14

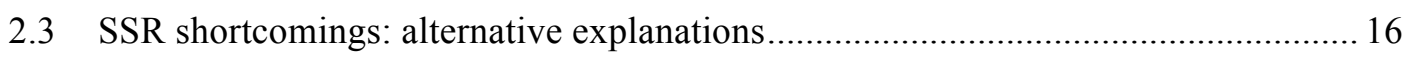

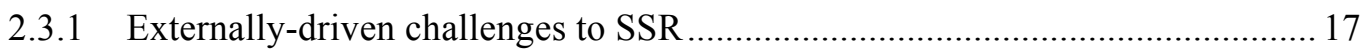

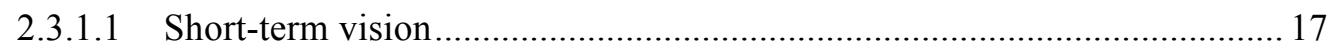

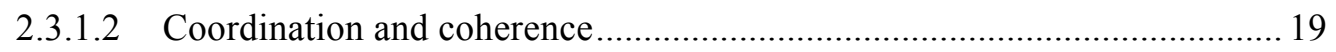

2.3.2 National ownership and domestic politics .................................................... 20

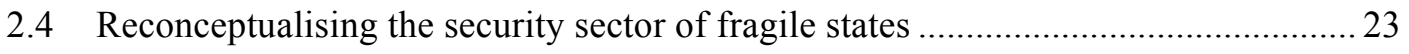




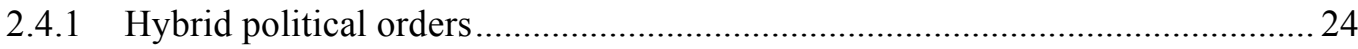

2.4.2 Security and justice provision in hybrid political orders ................................. 25

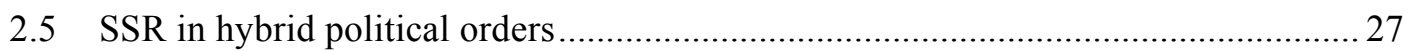

\section{Chapter: Introducing the Public Order Regime Framework and its Implications for SSR in Fragile States ............................................................................. 31}

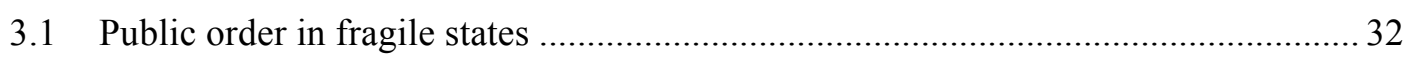

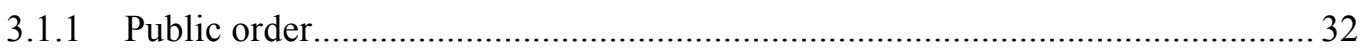

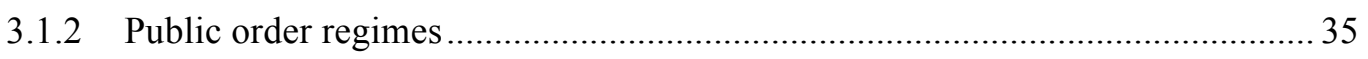

3.1.2.1 Monist and pluralist public order regimes............................................. 36

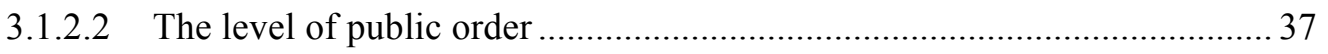

3.1.3 The institutional landscape of public order regimes....................................... 38

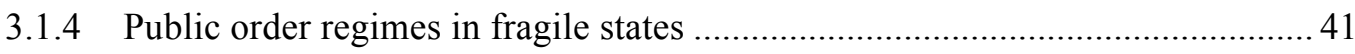

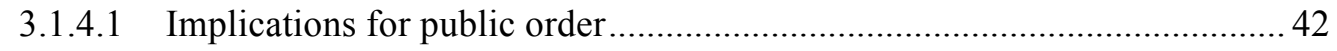

3.1.4.2 Examples of public order regimes in fragile states ................................. 42

3.1.4.2.1 Pluralist PORs dominated by non-state actors.................................. 43

3.1.4.2.2 Pluralist PORs with strong state and non-state actors ....................... 45

3.2 SSR in pluralist public order regimes and prospects for public order ...................... 47

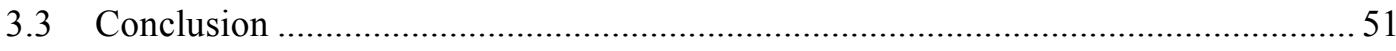

4 Chapter: Methodology .................................................................................................. 53

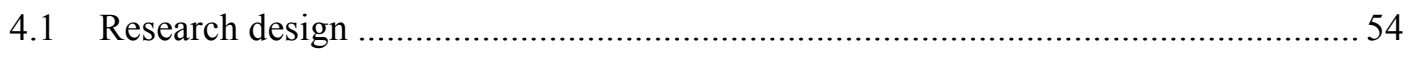

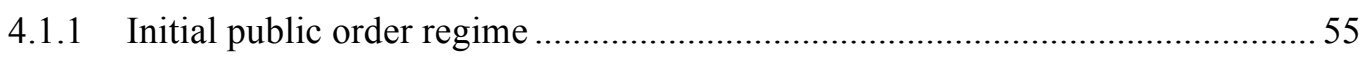

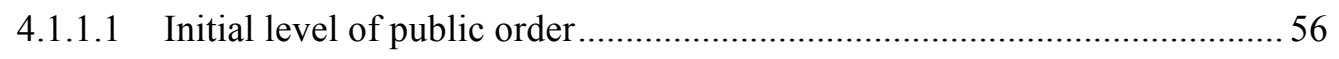

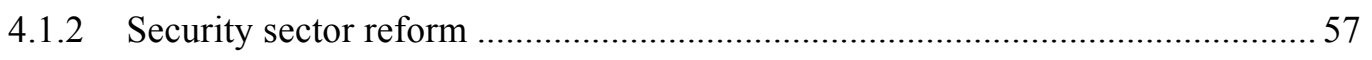

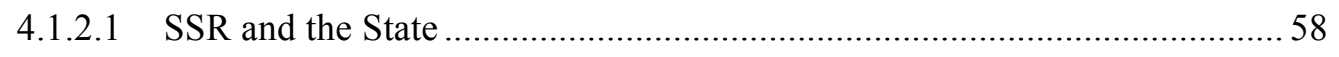

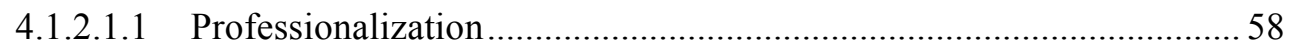

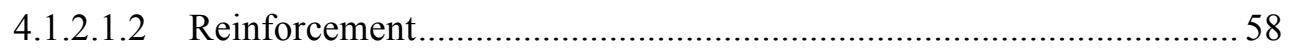




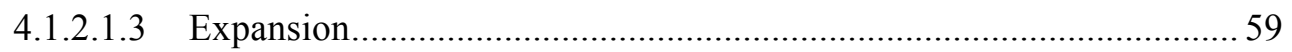

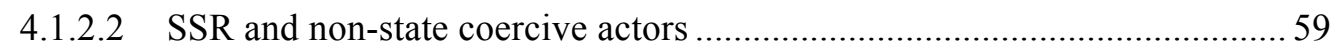

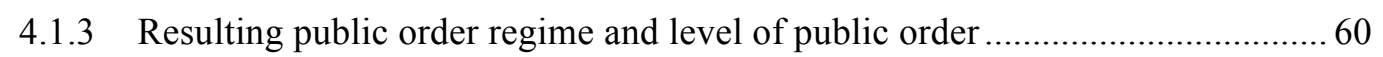

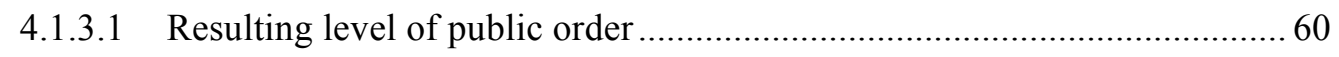

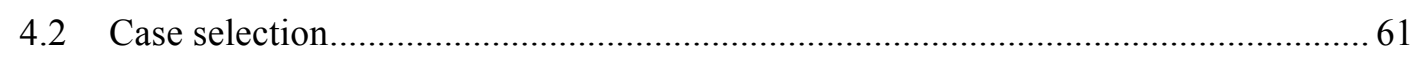

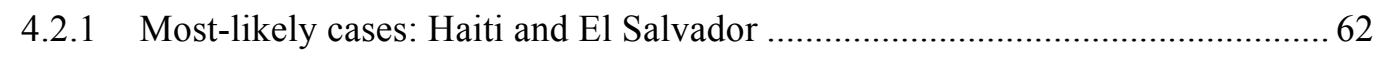

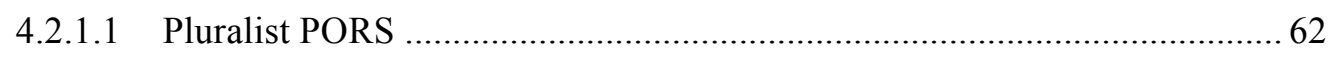

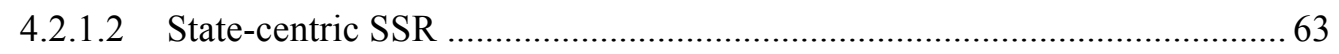

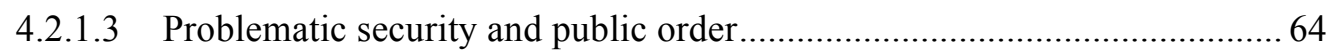

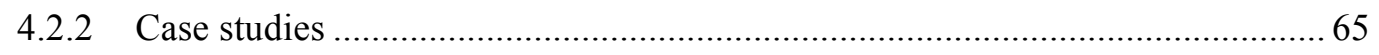

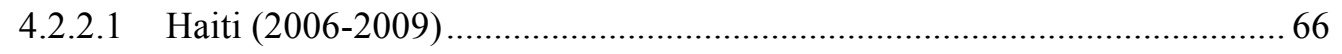

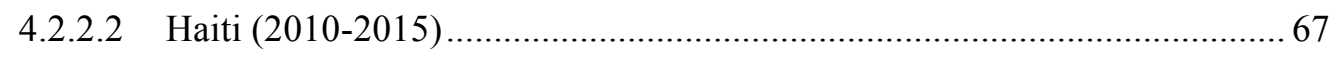

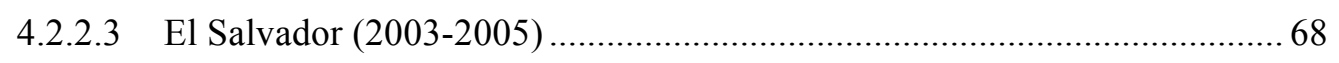

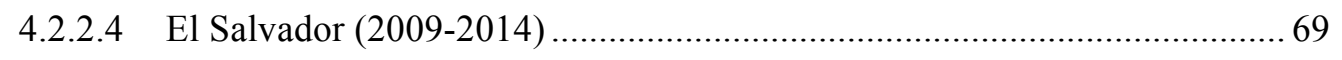

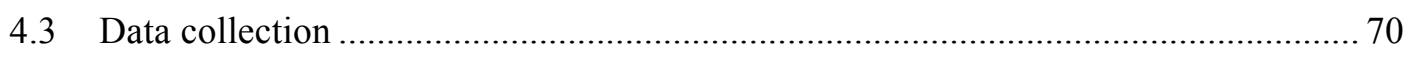

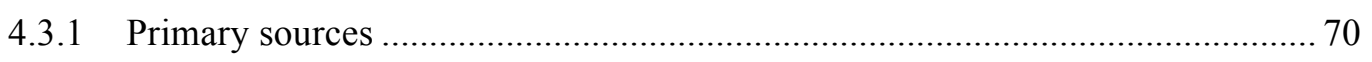

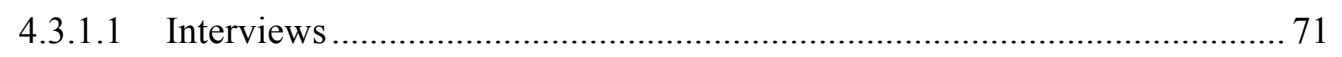

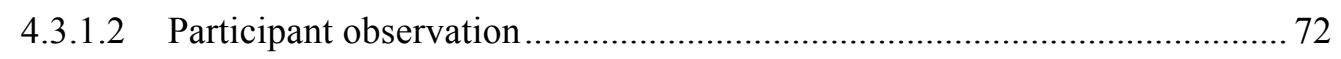

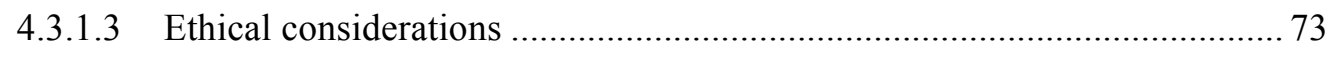

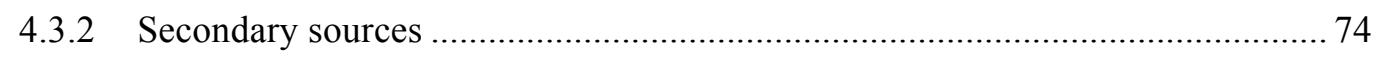

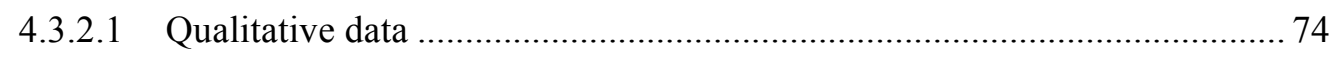

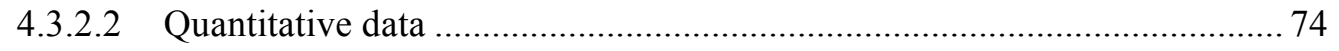

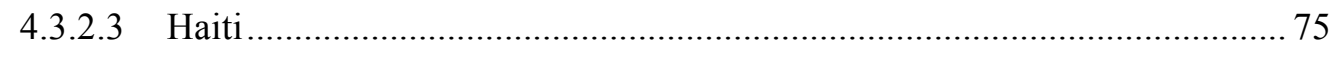

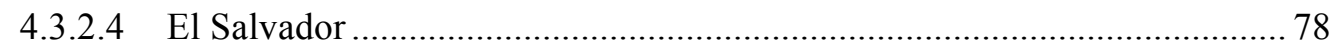

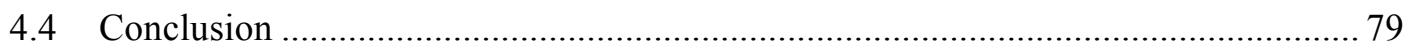


5 Chapter: Haiti (2006-2009) - Stabilisation through SSR, Disarmament, and Peace Building .................................................................................................................................. 81

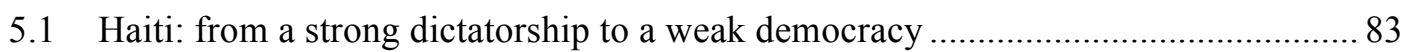

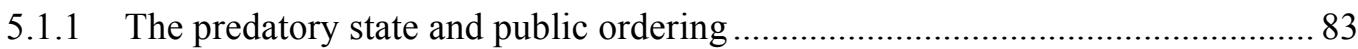

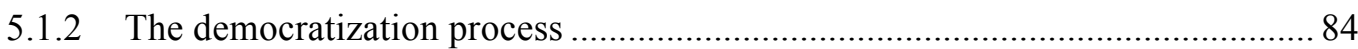

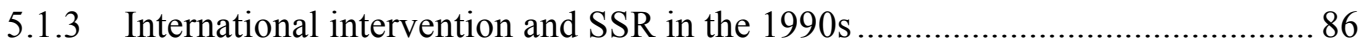

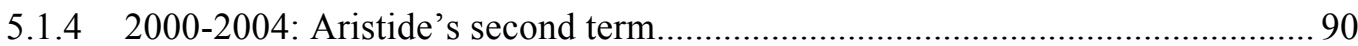

5.2 Port-au-Prince after Aristide: the supremacy of informal public ordering ................ 92

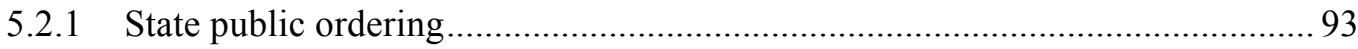

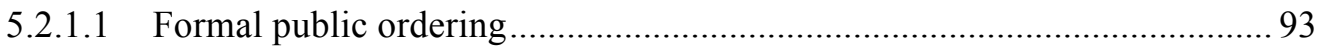

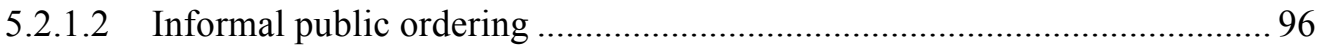

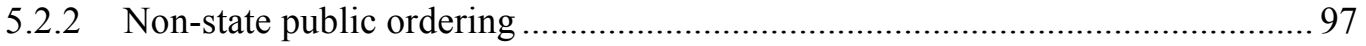

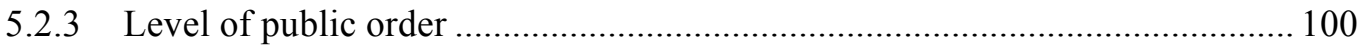

5.3 Security sector reform and stabilisation in Port-au-Prince .................................... 101

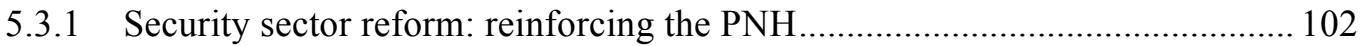

5.3.2 DDR and violence reduction: disarm or die ............................................... 103

5.4 Resulting public order regime

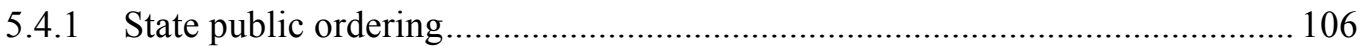

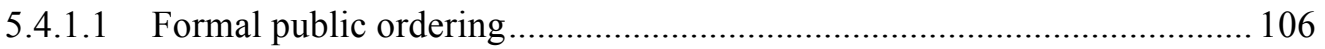

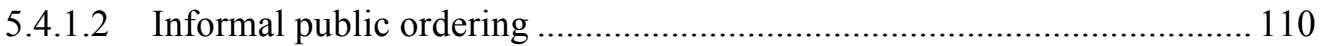

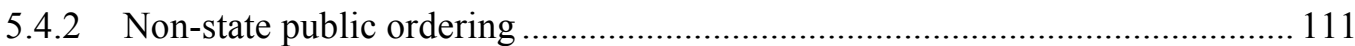

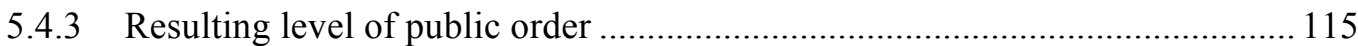

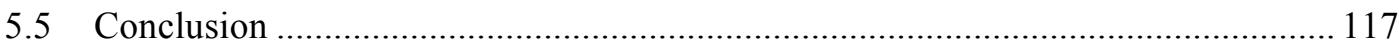

6 Chapter: Haiti (2010-2015) - State-centric SSR, Covert Clientelism, and Volatility................................................................................................................................. 119

6.1 The 2010 earthquake and its consequences on the POR ..................................... 120 
6.1.1 Direct consequences of the earthquake on the POR

6.1.1.1 State public ordering

6.1.1.2 Non-state public ordering

6.1.2 Resulting level of public order

6.2 SSR under President Martelly. 126

6.2.1 SSR: a professional police in a weak security sector 127

6.2.1.1 The PNH. 128

6.2.2 Dealing with non-state actors: marginalization of peace-building initiatives .. 131

6.3 The resulting public order regime: 2011-2015 133

6.3.1 State coercive actors 134

6.3.2 Formal public ordering 134

Informal public ordering 142

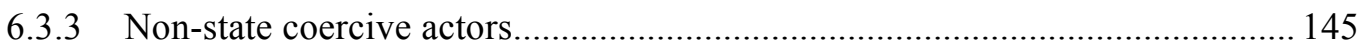

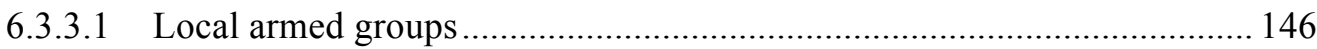

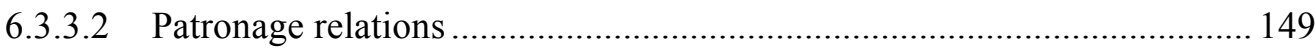

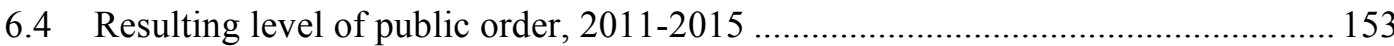

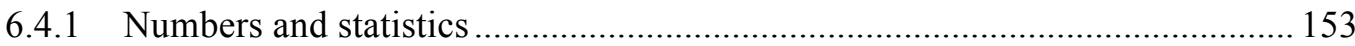

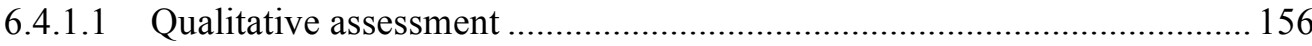

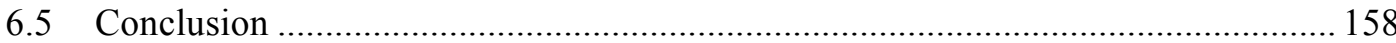

7 Chapter: El Salvador (2003-2005) - State Repression and Gang Violence under Mano Dura ................................................................................................................... 160

7.1 The Chapultepec Peace Accords and Post-war SSR ................................................... 164

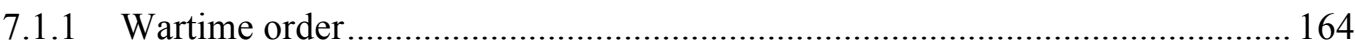

7.1.2 The Chapultepec Peace Accords .................................................................... 165

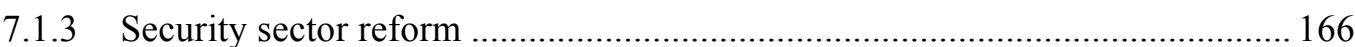

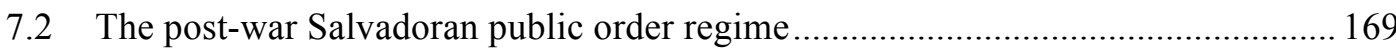




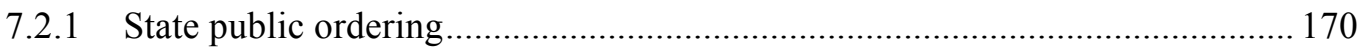

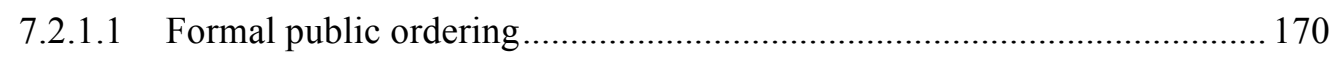

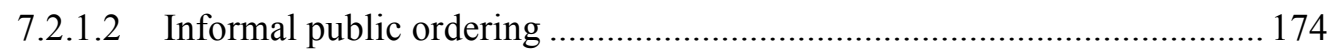

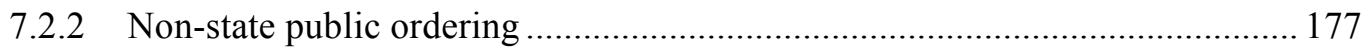

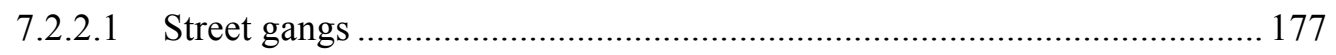

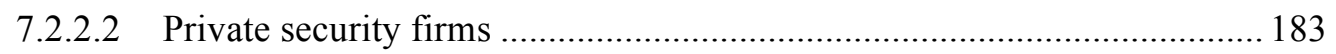

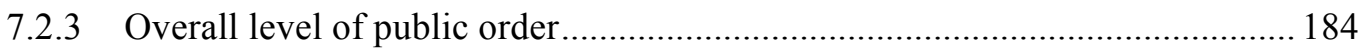

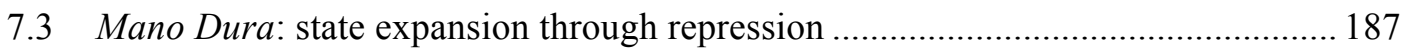

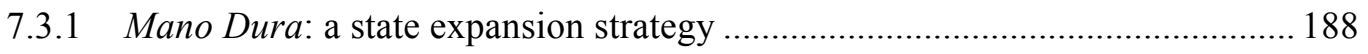

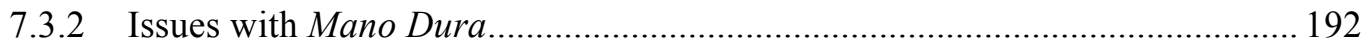

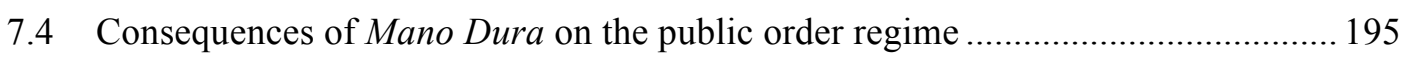

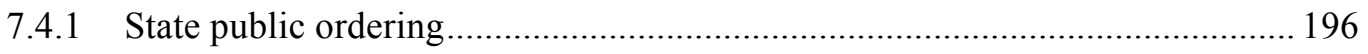

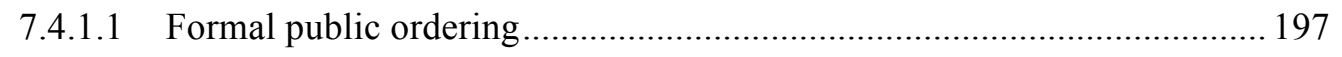

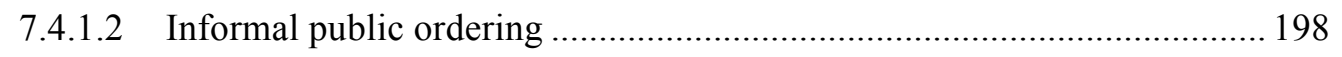

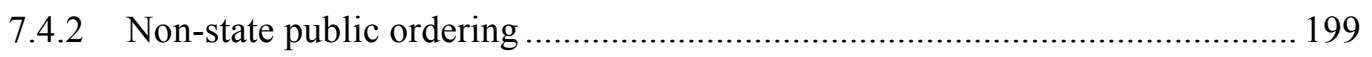

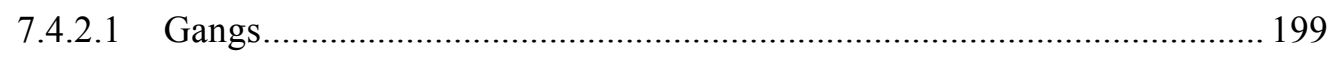

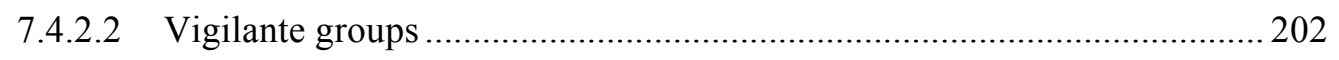

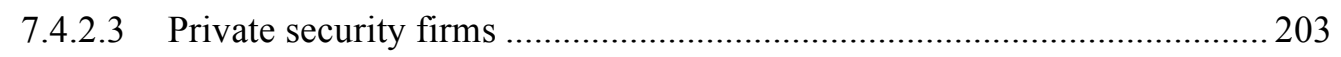

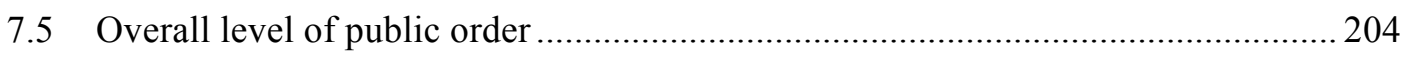

8 Chapter: EI Salvador (2009-2014) - Failed Reforms and Violence Management under Mauricio Funes.............................................................................. 208

8.1 Public security and SSR under the FMLN, 2009-2012 …................................ 210

8.1.1 Homicides in post-Mano Dura El Salvador .................................................211

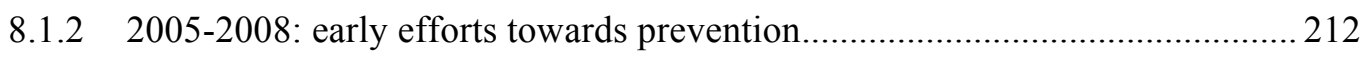

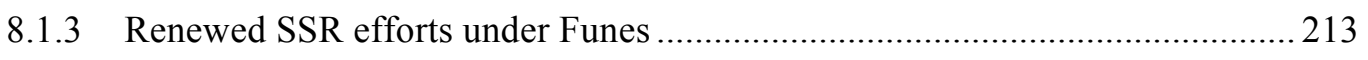

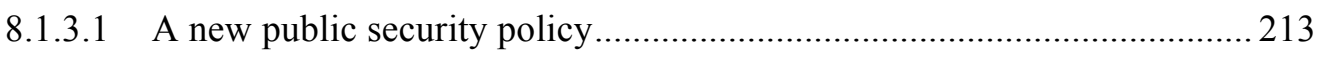


8.1.4 The persistence of reactive and repressive strategies, 2009-2011 _................. 217

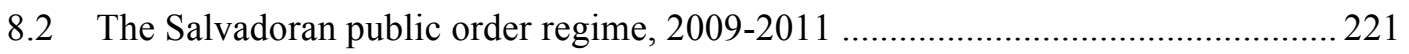

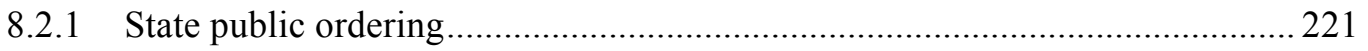

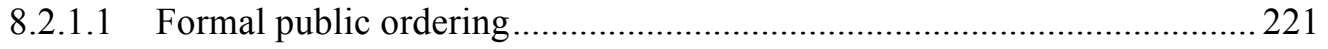

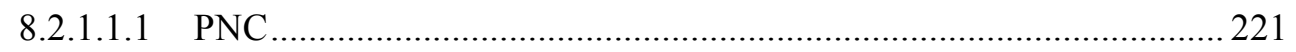

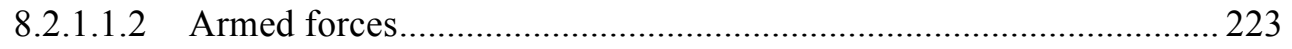

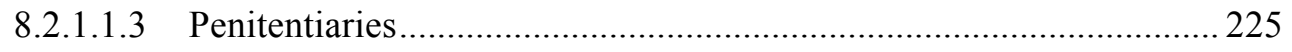

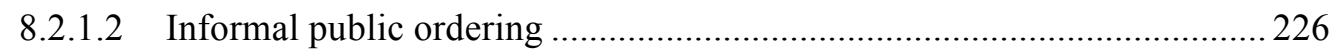

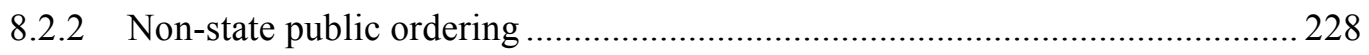

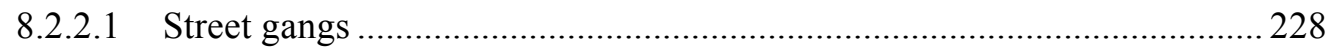

8.2.2.1.1 Local turf and influence over public order .................................... 228

8.2.2.1.2 Consequences of state repression on gangs' activities ..................... 232

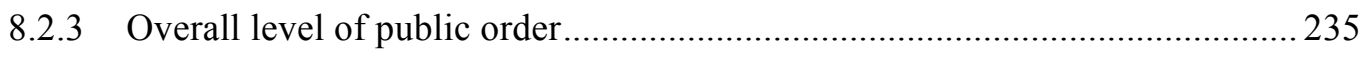

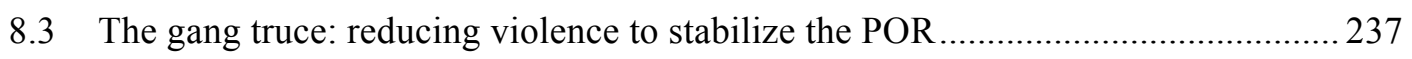

8.3.1 Negotiating and maintaining the ceasefire …............................................ 238

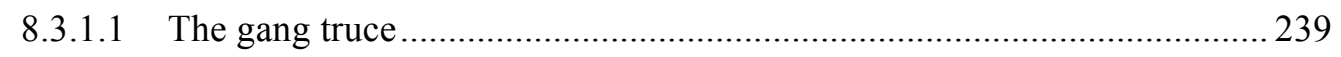

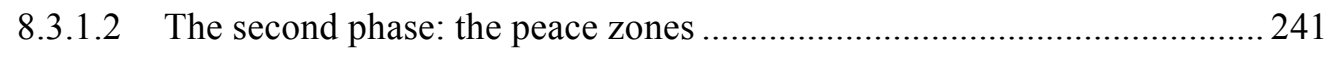

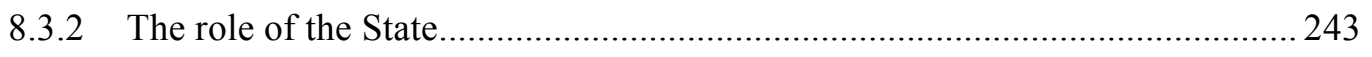

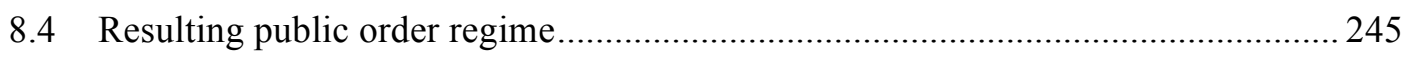

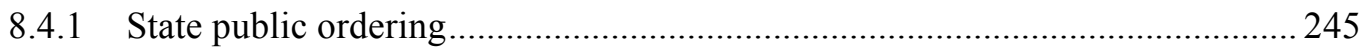

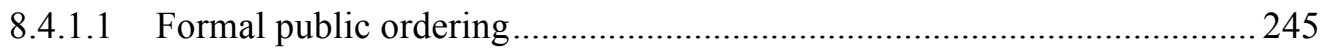

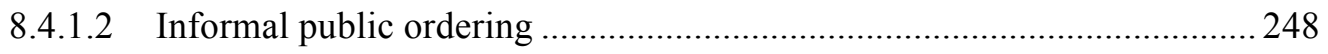

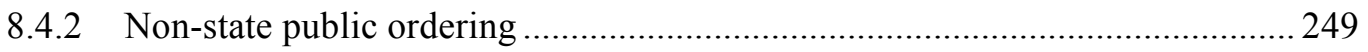

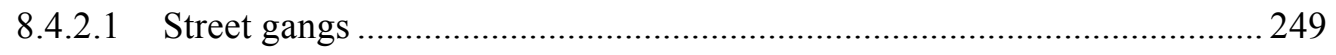

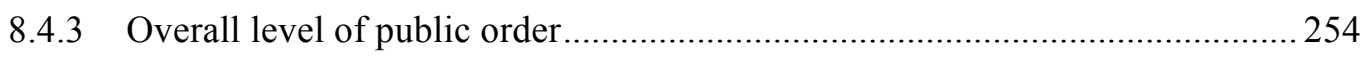


8.5 Conclusion

9 Chapter: Making Sense of SSR in Fragile States - The Contribution of the

Public Order Regime Framework .............................................................................. 259

9.1 Making sense of SSR in fragile states: Haiti and El Salvador ................................260

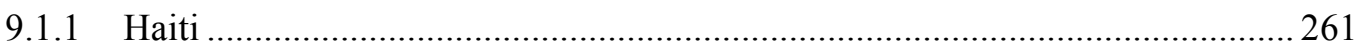

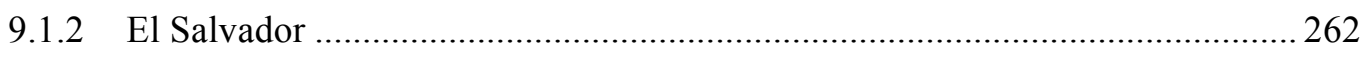

9.1.3 The main findings and their implications for the proposed theory ..................264

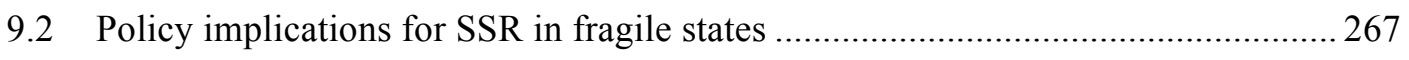

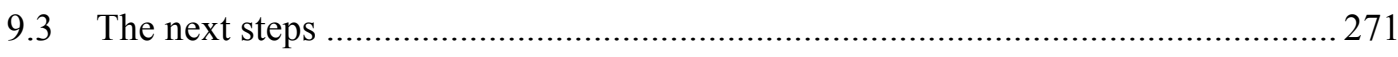

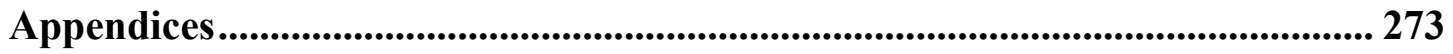

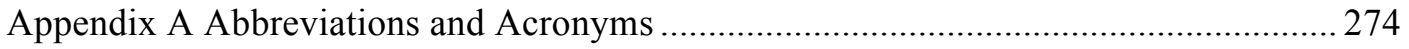

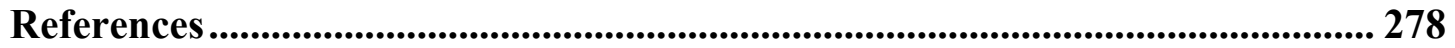




\section{List of Tables}

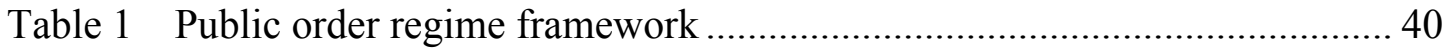

Table 2 Public order regime, Port-au-Prince, 2004-2006 ..................................... 93

Table 3 Public order regime, Port-au-Prince, 2010 ......................................... 121

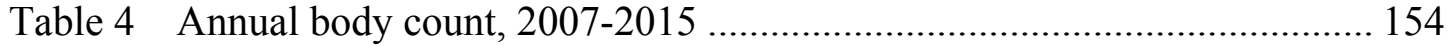

Table 5 The post-war Salvadoran public order regime, 1992-2002 _.................... 170

Table 6 Prison population, El Salvador .......................................................... 194

Table 7 Public order regime, El Salvador, 2009-2011_.................................... 221

Table 8 Military personnel involved in public security, 2008-2014..................... 224 


\section{List of Figures}

Figure 1 National homicide rate, El Salvador, 1992-2008 …............................. 185

Figure 2 National homicide rate, El Salvador, 2000-2007 ….............................. 188

Figure 3 National homicide rate, El Salvador, 2005-2014 ............................... 211

Figure 4 Monthly homicide numbers, El Salvador, 2011/11-2014/12 ….............. 238

Figure 5 Annual homicide numbers, El Salvador, 2009-2014............................ 238 


\section{List of Appendices}

Appendix A Abbreviations and Acronyms............................... 274 


\section{Chapter: Security Sector Reform and Public Order Regimes}

Since the end of the Cold War, the reform and transformation of state security institutions has been a core element of the international response to state fragility. Security sector reform (SSR) programs have been implemented with more or less success in a wide variety of contexts and environments. However, cases such as Haiti, Afghanistan, Iraq, Kosovo, Sierra Leone, El Salvador, and Timor-Leste suggest that SSR is a complex endeavour with unforeseen consequences. Despite years of investment, many countries where SSR was implemented still face a volatile domestic environment where social and political violence remains an important concern. State security institutions continue to be rather inefficient in maintaining public order, and non-state actors still play an important role in security provision.

Considerable investments by external actors, whether states or international organisations, do not appear enough to guarantee the success of SSR. In Afghanistan, the International Security Assistance Force has invested billions of dollars in the stabilization of the country and the reform of the national security institutions since 2001. In 2015 only, the United States (U.S.) provided US\$4 billions to support the development of the Afghan national security and defense forces through bilateral engagements, in addition to substantial contributions - more than USD 1.5 billion - from other donor countries to the Afghanistan Reconstruction Trust Fund. ${ }^{1}$ Yet despite the astonishing financial and human costs of state-building efforts in Afghanistan since $2001,^{2}$ the Afghan security forces are

\footnotetext{
1 “NATO and Afghanistan," North Atlantic Treaty Organization, May 7, 2015, http://www.nato.int/cps/en/natohq/topics_8189.htm.

2 John Bohannon, "Counting the Dead in Afghanistan," Science 331, no. 6022 (March 11, 2011): 1256-60, doi:10.1126/science.331.6022.1256.
} 
still unable to control large parts of the Afghan territory, ${ }^{3}$ and the war economy has turned - at best and only in part of the country - into a criminalized peace. ${ }^{4}$ As a result, the U.S. announced in October 2015 that it would maintain approximately 10,000 troops in Afghanistan until 2017..$^{5}$ In March 2017, in front of the Congress, the head of the U.S. Central Command pleaded for an increase in U.S. troops to continue to train and advise Afghan security forces. ${ }^{6}$ All in all, reinforcing the State's security capacities has been insufficient to improve security and stability in the country, and there is evidence that warlords turned governors have been more successful in maintaining order and providing security with their "unreformed" private armies than the Afghan government's security forces themselves. ${ }^{7}$

Elsewhere, SSR in itself appears to be a destabilizing factor. In the Democratic Republic of the Congo, the deployment of the state police to remote areas has actually contributed to insecurity. ${ }^{8}$ In 2010 , the United Nations (UN) supported the deployment of the Congolese police in volatile villages in the eastern part of the country through the

\footnotetext{
${ }^{3}$ According to Vanda Felbab-Brown, the conflict opposing the Taliban and the Afghan security forces has become bloodier than ever. Civilian casualties are also increasing and insecurity has spread throughout the country. For a detailed account, see Vanda Felbab-Brown, "Blood and Faith in Afghanistan: A June 2016 Update," Brookings, May 26, 2016, https://www.brookings .edu/research/blood-and-faith-in-afghanistan-ajune-2016-update/; Vanda Felbab-Brown, "Blood and Hope in Afghanistan: A June 2015 Update," The Brookings Institution, May 26, 2015, http://www.brookings.edu/research/papers/2015/05/26-isis-talibanafghanistan-felbabbrown.

${ }^{4}$ Jonathan Goodhand, "Corrupting or Consolidating the Peace? The Drugs Economy and Post-Conflict Peacebuilding in Afghanistan,” International Peacekeeping 15, no. 3 (June 2008): 410-11.

${ }^{5}$ Matthew Rosenberg and Michael D. Shear, "In Reversal, Obama Says U.S. Soldiers Will Stay in Afghanistan to 2017," The New York Times, October 15, 2015, http://www.nytimes.com/2015/10/16/world/asia/obama-troop-withdrawal-afghanistan.html.

${ }^{6}$ Paul Mcleary, "More U.S. Troops Bound for Afghanistan, As Marines, Commandos, Arrive In Syria," The Cable (Foreign Policy), March 9, 2017, https://foreignpolicy .com/2017/03/09/more-us-troopsafghanistan-marines-syria-commandos-iraq/.

${ }^{7}$ Dipali Mukhopadhyay, Warlords, Strongman Governors, and the State in Afghanistan (Cambridge: Cambridge University Press, 2014).

${ }^{8}$ Séverine Autesserre, “Trouble in Peaceland," Foreign Policy, October 6, 2015, https://foreignpolicy.com/2015/10/06/trouble-in-peaceland-united-nations-congo-development/.
} 
construction of police stations and the dispatching of police officers. However, once the police was established, it faced "remnants of rebel groups and militias" "with which it had to compete for control, which further destabilized the region. Moreover, the police lacked support from the central government and turned to predation to fulfill their needs. Overall, the deployment of the state police made things worse.

These examples illustrate how difficult it is for SSR to actually meet its overarching goal: improve public order and reduce violence in order to enable social, political, and economic development. ${ }^{10}$ This dissertation seeks to answer the following question: why have interventions in the security sector of fragile states often failed to reduce violence and increase the level of public order? The literature on state building and governance already offers some explanations for the lack of success of SSR, including issues related to capacity, national and local ownership, coordination, and political will. However, even though these factors are known and increasingly taken into consideration in the elaboration of SSR strategies, success in recent interventions remains elusive.

\subsection{The argument}

In this dissertation, I argue that the problem regarding SSR success or lack thereof lies in part in the way these reforms continue to be understood. Indeed, SSR tends to remain state-centric, without much consideration for the complex environment in which it usually takes place. First, I contend that the production of public order in fragile states involved a constellation of actors. In contexts where the State does not hold a monopoly on the legitimate use of coercive force, non-state actors often produce public order and

\footnotetext{
${ }^{9}$ Ibid.

${ }^{10}$ OECD-DAC, The OECD DAC Handbook on Security System Reform (SSR): Supporting Security and Justice (Paris: Organisation for Economic Co-operation and Development, 2007), 20.
} 
provide some form of security and protection. ${ }^{11}$ To make sense of those hybrid polities, I propose a new approach to conceptualize more systematically how public order is produced in fragile states and to better understand the sometimes ambiguous impact of SSR in those countries.

Second, I contend that the complexity of the environment in which SSR usually takes place influences the success of these reforms and their ability to improve security. By expanding the State's capacity to claim control over the means of violence, SSR sometimes disrupts existing security arrangements without fully replacing them. Tensions between state and non-state actors can then lead to conflict. As a result, overall security is not enhanced. SSR experts only recently started to recognize the role played by informal networks and non-state actors in the production of public order, and current programs continue to be mostly state-centric. This study brings that issue to the center of the discussion on the conditions of success for SSR in fragile states.

\subsection{Structure of the dissertation}

Making sense of the structure of specific hybrid polities and the effect of SSR on these countries is the core objective of this dissertation. In this first chapter, I discuss the emergence and evolution of SSR as a policy framework, highlighting the need to better adapt SSR to the complexity of fragile states. In the following chapter, I first develop an analytical framework to better understand how public order is produced in fragile states, introducing the concept of public order regime. I then discuss why SSR, as it is currently designed, is unlikely to improve public order and might actually be counter-productive.

\footnotetext{
${ }^{11}$ Volker Boege et al., "On Hybrid Political Orders and Emerging States: State Formation in the Context of "fragility"” (Berghof Research Center for Constructive Conflict Management, 2008).
} 
Chapter three details the research design, case selection rationale, and ethical considerations.

The next four chapters present the case studies that probe the proposed hypotheses. Chapters four and five look at the immediate consequences of SSR programming on public order and security in Haiti, following the deployment of the Mission des Nations Unies pour la Stabilisation en Haiti (MINUSTAH) in 2004. The first case explores the consequences of a mixed SSR strategy toward non-state armed actors on security in Portau-Prince between 2006 and 2009. The fifth chapter looks at the consequences of the refusal by president Michel Martelly to formally engage with non-state actors on SSR programming and public order in the country between 2011 and 2015.

Chapter six and seven turn to the case of post-war El Salvador. Following the end of the civil war, El Salvador undertook important reforms in its security and justice sector. By the end of the 1990s, international actors deemed the reforms successful. Yet, Salvadoran homicide rates increased significantly in the early 2000s, making El Salvador one of the world's most violent country. In chapter six, I look at the long-term consequences of incomplete SSR on crime and violence management policies in the early 2000s. I contend that incomplete post-war reforms undermined the ability of the Salvadoran State to control its territory and managed adequately gangs who were deemed disruptive for security and order. Chapter seven focuses on the consequences of the statesponsored gang truce (2012-2013) on public order. I argue that the Funes administration (2009-2014), unable to implement necessary reforms to increase the effectiveness of security institutions to deal with crime and violence, sponsored a gang truce to reduce homicides. The last chapter discusses the core findings of the dissertation as well as their 
policy implications, and reflects on the next steps of a broader research agenda on public ordering and violence in fragile states. 


\section{Chapter: A State of the Debate on Security Sector Reform}

In this chapter, I set the table for a reflection on the interaction between SSR, the production of public order in fragile states, and ultimately violence. I first discuss the origins and evolution of SSR as a concept. I then look at the elaboration of SSR as a policy framework in the 2000s. Third, I provide an overview of the different explanations already proposed in the literature to explain the lack of success of SSR in fragile states. Fourth, I introduce the scholarship on hybrid political order. This literature offers some useful insights on the production of authority and order in fragile states, and on the role played by informality and non-state actors in security provision. However, this new approach does not yet provide clear analytical tools to understand more systematically how public order is produced outside of strong Western states, and how SSR actually affects those polities. This chapter provides the foundation for the development of a new theoretical approach to better explain how the reinforcement of state capacities does not necessarily result in a clear improvement of public order and security conditions in fragile states. In some cases, it can even actually be disruptive for the production of public order, and ultimately undermine SSR's core objective: making people safer.

\subsection{The origins of SSR}

The collapse of the Soviet Union led to an important shift in the conduct of foreign interventions. Intra-state wars and their resolution received unprecedented attention, and new responses were designed and implemented, from strict peacekeeping to peacemaking 
and peace building. ${ }^{12}$ Interventions became increasingly complex, having for objective not only to end war, but also to build peace and reconstruct societies. SSR emerged as one of the main responses of the international community to these new challenges, addressing both instability and human suffering. A reflection of these developments, SSR sits at the crossroad between the concept of human security that emerged in the early 1990s and a more traditional conception of state security, embodied by the state-building paradigm.

\subsubsection{Human security}

Following the publication of the Agenda for Peace by the UN Secretary General Boutros Boutros-Ghali in 1992, the concept of security was broadened to include not only the right of the State to defend its sovereignty against external and internal threats, but also its responsibility to ensure the safety and wellbeing of its population. ${ }^{13}$ The report points to the potential need for peace-building efforts to include the training of security personnel and the reinforcement of governmental institutions to ensure the security of populations. ${ }^{14}$ Human security quickly gained popularity, ${ }^{15}$ but genocide and ethnic cleansing in Rwanda and Bosnia demonstrated the difficulty to actually ensure human security in a system where state sovereignty persists as the core organising principle.

During that period, a strong belief that stability and democracy would lead to peace and development through accountability, transparency, and respect for human rights

\footnotetext{
${ }^{12}$ Alvaro de Soto, "Foreword," in Political Economy of Statebuilding; Power after Peace, ed. Mats Berdal and Dominik Zaum, Routledge, Routledge Studies in Intervention and Statebuilding (London; New York, 2012), xvii-xx.

${ }^{13}$ Boutros Boutros-Ghali, “An Agenda for Peace,” Report of the Secretary-General (New York: United Nations, June 17, 1992).

${ }^{14}$ Boutros Boutros-Ghali, “An Agenda for Peace,” Report of the Secretary-General (New York: United Nations, June 17, 1992), 15.

${ }^{15}$ Lloyd Axworthy, "Human Security and Global Governance: Putting People First," Global Governance 7 , no. 1 (2001): 19-23; UNDP, "Human Development Report 1994” (Oxford University Press, 1994).
} 
reinforced concerns for people's security. Efforts to reform security institutions in the 1990s varied from downsizing and professionalizing security forces in former Soviet satellites, like Ukraine, ${ }^{16}$ to creating all new security institutions in line with good governance principles, such as in Haiti. ${ }^{17}$ Yet in practice and due to the lack of clear SSR guidelines, there was often a disconnect between the necessity for the State to ensure its sovereignty and the integrity of its territory on the one hand, and the responsibility of central governing authorities to provide security to their population in a transparent, accountable, and effective manner on the other hand. Too often, the focus was put on capacity building and the necessity for the State to protect its borders. More limited attention was given in practice to how the new security institutions deliver services to the population, and the sustainability of reform efforts towards increased accountability and transparency. In other words, early SSR programs as a key component of state-building initiatives often emphasized security of the State over people's safety and wellbeing.

\subsubsection{The state-building paradigm}

In parallel to these developments at the multilateral level, the United States articulated the state-building paradigm in the second half of the 1990s as a response to the perceived breakdown of state authority worldwide. Wars in Bosnia and Somalia led policy-makers and researchers alike to contend that the collapse of state authority leads to an authority vacuum, which feeds insecurity and instability. ${ }^{18}$ SSR quickly became a core

\footnotetext{
${ }^{16}$ Philipp H. Fluri and V.G. Radetskiy, Security Sector Reform in Ukraine: Quo Vadis?, DCAF (Geneva, 2010).

${ }^{17}$ Johanna Mendelson-Forman, "Security Sector Reform in Haiti," International Peacekeeping 13, no. 1 (2006): 14-27.

${ }^{18}$ Barry R. Posen, “The Security Dilemma and Ethnic Conflict," Survival 35, no. 1 (1993): 27-47.
} 
component of this paradigm, which seeks to (re)stablish the State's monopoly over the use of force.

State building gained additional momentum after September 2001. The United States' 2002 National Security Strategy notes that: "America is now threatened less by conquering states than we are by failing ones." ${ }^{, 19}$ What would become the Bush Doctrine put the emphasis on intervention and regime change, illustrated by the U.S.-led intervention in Afghanistan in 2001 and the invasion of Iraq in 2003. In both cases, the reengineering of the state apparatus, including the reform of its security institutions, was as a key element of the intervention strategy.

Under the state-building paradigm, the Weberian State is the only viable outcome in terms of security, stability, and public good provision. ${ }^{20}$ Fragile states are conceived as polities where the breakdown of state authority creates a governance gap and a security vacuum, ${ }^{21}$ which can be exploited by transnational crime or terrorist organisations. As a result, their very existence represents a threat to regional and international security. ${ }^{22}$ If advocates of the state-building paradigm recognize that non-state actors and informal arrangements can provide security and produce public order, they assume that, ultimately, such arrangements necessarily leads to brutal and ineffective rule. Non-state actors are

\footnotetext{
${ }^{19}$ United States of America, "The National Security Strategy of the United States of America" (Washington, D.C.: The White House, September 2002), 1.

${ }^{20}$ Charles T. Call and Vanessa Wyeth, Building States to Build Peace (Boulder: Lynne Rienner Publishers, 2008); Francis Fukuyama, State-Building: Governance and World Order in the 21St Century, 1st ed. (Ithaca: Cornell University Press, 2004); Robert I. Rotberg, "The Failure and Collapse of Nation-States; Breakdown, Prevention and Repair," in When States Fail: Causes and Consequences, ed. Robert I. Rotberg (Princeton, N.J: Princeton University Press, 2004), 1-49.

${ }^{21}$ David A. Lake and Donald S. Rothchild, The International Spread of Ethnic Conflict: Fear, Diffusion, and Escalation (Princeton, N.J: Princeton University Press, 1998); Posen, "The Security Dilemma and Ethnic Conflict."

${ }^{22}$ See, for example, Ken Menkhaus, "State Failure and Ungoverned Space," in Ending War, Consolidating Peace: Economic Perspectives, ed. Mats Berdal and Achim Wennmann, vol. 50, Adelphi Series (New York: Routledge, 2010), 171-88; Robert I. Rotberg, State Failure and State Weakness in a Time of Terror (Washington, DC: Brookings Institution Press, 2003).
} 
assumed to be less accountable, less effective, less responsible, and less respectful of human rights than the security institutions of the Weberian State.

To sum up, SSR finds its roots in the promotion of human-centred security and the supremacy of the Western model of statehood in the articulation of foreign intervention in fragile states after 1990. Complementarity but also tensions between these two influences can be perceived in the articulation of SSR as a detailed policy framework by international organisations in the 2000s, the subject of the next section.

\subsection{SSR as a policy framework}

The United Kingdom's Department for International Development (DFID) first formulated the concept of SSR in $1998 .{ }^{23}$ By that time, its principles (good governance, basic security provision, and national ownership) had already guided reform efforts in several countries, including Bosnia, Palestine, El Salvador, Sierra Leone, and Cambodia. While SSR became increasingly common and generated significant interest from countries' development agencies and international organisations active in the international security and the development realms, there was actually little consensus on what precisely constituted SSR and what were its main objectives. Efforts to conceptualize SSR increased in the 2000s, especially through the Development Assistance Committee of the Organisation for Economic Co-operation and Development (OECD-DAC) and the United Nations. This section discusses how the policy community defines SSR and its main objectives, and the degree to which non-state actors are considered as a component of the security system.

\subsubsection{Definitions}

${ }^{23}$ Jane Chanaa, Security Sector Reform: Issues, Challenges and Prospects (London ; New York: Routledge, 2002), 27. 


\subsubsection{The OECD-DAC definition}

The OECD-DAC has played a key role in the evolution of international security assistance. Through the 1990s, its focus shifted from concerns over civil-military relations and military expenditures, reflecting issues at play in Eastern Europe, to increased interest into the security-development nexus and questions of conflict prevention, resolution, and reconstruction, which dominated the agenda in the Global South, particularly in Sub-Saharan Africa. ${ }^{24}$ In 2005 and 2007, as a result of a reflection undertaken almost a decade earlier by the Task Force on Conflict, Peace and Development, the OECD-DAC published two key documents ${ }^{25}$ on SSR that would become the basis for many donors and contributors in the elaboration of their own SSR strategy. ${ }^{26}$

According to the OECD-DAC, SSR aims to transform "the 'security system' [...] to manage and operate the system in a manner that is more consistent with democratic norms and sound principles of good governance, and thus contributes to a wellfunctioning security framework." ${ }^{27}$ SSR seeks to improve basic security and justice provision, establish "an effective governance, oversight and accountability system,"28 promote and develop local ownership, and ensure the sustainability of security and justice delivery. Ultimately, "SSR helps create a secure environment conducive to other

\footnotetext{
${ }^{24}$ Ibid., 24.

${ }^{25}$ OECD-DAC, The OECD DAC Handbook on Security System Reform (SSR): Supporting Security and Justice; A. OECD-DAC, Security Sector Reform and Governance, DAC Guidelines and Reference Series (Paris: OECD Publishing, 2005).

${ }^{26}$ See, for example, Government of Canada, "Canadian Guidelines for Security System Reform" (Government of Canada, 2013), 4; U.S. Agency for International Development, U.S. Department of Defense, and U.S. Department of State, "Security Sector Reform" (United States, February 2009), 3.

${ }^{27}$ OECD, Helping Prevent Violent Conflict (Paris: Organisation for Economic Co-operation and Development, 2001), 38, http://www.oecd-ilibrary.org/content/book/9789264194786-en.

${ }^{28}$ OECD-DAC, The OECD DAC Handbook on Security System Reform (SSR): Supporting Security and Justice, 10 .
} 
political, economic and social developments, through the reduction of armed violence and crime. ${ }^{29}$

\subsubsection{The UN approach}

In 2007, the UN Security Council requested a report from the Secretary General on the UN approach to SSR. Published in 2008, the report highlights the extensive experience of the UN in the reinforcement of state security capacity in post-conflict settings, but deplores the fact that most UN initiatives have relied on ad hoc approaches. As a result, an SSR Unit was created in 2008 inside the Department of Peace Keeping Operations (DPKO). Its mandate was to develop a system-wide approach to SSR, embodied in the 2012 UN Perspective on Security Sector Reform. ${ }^{30}$

According to this document, SSR is conceived as "a process of assessment, review and implementation as well as monitoring and evaluation led by national authorities that has as its goal the enhancement of effective and accountable security for the State and its peoples without discrimination and with full respect for human rights and the rule of law." ${ }^{31}$ Promoting a system-wide approach, the UN considers that the "fundamental objective of SSR is to make people feel safer., ${ }^{32}$

Both definitions of SSR consider that the ultimate objective of these reforms is actually to ensure the security of the people through the reduction and control of violence. Perhaps unsurprisingly, the OECD-DAC's Handbook on Security System

\footnotetext{
${ }^{29}$ Ibid., 21.

${ }^{30}$ UN DPKO, The United Nations SSR Perspective (New York: United Nations, 2012).

${ }^{31}$ Ibid.

${ }^{32}$ Ibid., 5.
} 
Reform adopts an operational approach to SSR, while the United Nations' definition of SSR core components and objectives is broader and more normative.

\subsubsection{Non-state actors and informal arrangements}

The OECD-DAC and the UN both understand the importance of a wide approach to SSR that recognizes the role played by state and non-state actors in security provision. The 2007 OECD-DAC's Handbook states that SSR should include core security actors, management and oversight bodies, justice and rule of law institutions, and non-statutory security forces. Core security actors refer to the armed forces, the police and gendarmerie, intelligence services, customs authorities, as well as local security units, such as civil defence forces, national guards, and militias. ${ }^{33}$ Non-statutory actors include "liberation armies, guerrilla armies, private security companies [and] political parties militias." 34

The UN includes "non-state security providers" and the civil society in its systemwide approach to SSR. Throughout the UN Perspective on Security Sector Reform, the organization also recognizes the role often played by informal arrangements and nonstate actors in security and justice delivery: "non-State actors that could be considered as part of the security sector include customary or informal authorities and private security services." 35 There is however very little insight in the document on how SSR should actually engage with those actors.

Hence, the SSR policy community recognizes on paper the role and place of non-state actors and informal arrangements in security provision. The OECD-DAC even highlights

\footnotetext{
${ }^{33}$ OECD-DAC, The OECD DAC Handbook on Security System Reform (SSR): Supporting Security and Justice, 10.

${ }^{34}$ Ibid.

${ }^{35}$ UN DPKO, The United Nations SSR Perspective, 5.
} 
that non-state security and justice delivery could actually be the rule rather than the exception in sub-Saharan Africa. ${ }^{36}$ However, the concrete role of non-state actors and informal arrangements in the provision of security is not fully factored in. Indeed, while militias are included in "core security actors" by the OECD-DAC, the fact that they often act at the frontier or outside the state legal system is not recognized by the organisation. Additionally, the list of non-state actors provided by the OECD-DAC (liberation armies, guerrilla armies, private security companies, political parties militias) resonates well in a post-conflict context. However, it does not include a wide range of non-state actors who fulfill similar functions but who do not necessarily have political motives. For instance, vigilante group, gangs, and criminal organisations that are known to play a role in spaces where the State's presence is limited do not fit well in the categories proposed by the OECD-DAC. ${ }^{37}$

Logically, given this conceptual gap, few strategies have been designed and implemented to deal systematically with non-state and informal mechanisms of security provision. In fact, international agencies appear to be reluctant to effectively engage with non-state actors and informal arrangements. A case in point is the second UN report on SSR published in 2013. In this document, the UN Secretary General Ban Ki-Moon recognizes the role of non-state actors and informal governance practices in security and

\footnotetext{
${ }^{36}$ The document states: "evidence suggesting that in sub-Saharan African at least $80 \%$ of justice services are delivered by non-state providers should guide donors, encouraging them to take a balance approach to supporting state and non-state provision.” See OECD-DAC, The OECD DAC Handbook on Security System Reform (SSR): Supporting Security and Justice, 17.

${ }^{37}$ See, for example, Moritz Schuberth, "A Transformation from Political to Criminal Violence? Politics, Organised Crime and the Shifting Functions of Haiti's Urban Armed Groups," Conflict, Security \& Development 15, no. 2 (March 15, 2015): 169-96, doi:10.1080/14678802.2015.1030950; Louis-Alexandre Berg, "Young but Not Alone; Youth Organizations and the Local Politics of Security Provision," in Policing and the Politics of Order-Making, ed. Peter Albrecht and Helene Maria Kyed (London ; New York: Routledge, 2015), 159-77; Bruce Baker, Multi-Choice Policing in Africa (Uppsala: Nordiska Afrikainstitutet, 2008).
} 
justice, but he also highlights that they can undermine security and violate core principles guiding SSR, such as human rights. More importantly, he states: "the United Nations recognizes the relevance of those actors but does not, as yet, see how best to engage with them. There is a need to better understand and address their role in the provision of security and in security sector reform more broadly." 38

This statement summarizes the main problem of SSR and the focus of this dissertation: despite the increasing recognition of the role played by non-state actors and informal arrangements in security provision and public order, SSR lacks tools and strategies to engage with those actors and include them in the reform process. As implemented by the international community, SSR remains state-centric and focuses on technical aspects of the process, such as training and capacity building of state security institutions.

\subsection{SSR shortcomings: alternative explanations}

While SSR is widely recognized, accepted, and implemented as a core element of state building by the policy community, it remains largely unsuccessful in practice..$^{39}$

\footnotetext{
${ }^{38}$ United Nations, "Securing States and Societies: Strengthening the United Nations Comprehensive Support to Security Sector Reform," Report of the Secretary-General A/69/970-S/2013/480 (New York: United Nations, August 13, 2013), 5.

${ }^{39}$ Most scholars of SSR tend to agree on the limited success of these reforms. See, for example, Mustafa Tahani, "Insecurity through Security Sector Reform," Ethnographic Papers (School of Oriental and African Studies, June 2015), 2; Louis-Alexandre Berg, "Guns, Laws and Politics: The Political Foundations of Rule of Law and Security Sector Reform," Hague Journal on the Rule of Law 4, no. Special Issue 01 (2012): 430, doi:10.1017/S1876404512000024; Ursula C. Schroeder and Fairlie Chappuis, "New Perspectives on Security Sector Reform: The Role of Local Agency and Domestic Politics," International Peacekeeping 21, no. 2 (March 15, 2014): 135, doi:10.1080/13533312.2014.910401; Louise Riis Andersen, "Security Sector Reform and the Dilemmas of Liberal Peacebuilding," DIIS Working Paper (Copenhagen. Denmark: Danish Institute for International Studies, 2011); Bruce Baker, "The Future Is Non-State," in The Future of Security Sector Reform, ed. Mark Sedra, Centre for International Governance Innovation (Waterloo (On), 2010), 208-28; Charles T. Call and Elizabeth Cousens, Ending Wars and Building Peace: Coping with Crisis (New York: International Peace Academy, 2007); Mark Sedra, "Security Sector Reform in Afghanistan and Iraq: Exposing a Concept in Crisis," Journal of Peacebuilding \& Development 3, no. 2 (2007): 7-23; Louise Riis Andersen, "When Security Is Found Beyond the State: Suggestions for a Revised
} 
State-centric efforts in the security sector have showed very little tangible results beyond increased capacities. Violence and poor public order remain an issue in many countries targeted by those interventions, including Afghanistan, Haiti, Iraq, Palestine, Bosnia, Kosovo, Sierra Leone, and Timor-Leste.

The literature on SSR traces its shortcomings to two groups of factors: those related to the intervention itself and to external stakeholders, focussing on issues of capacity and resources, coordination and integration; and those related to national ownership of the reform process or lack thereof.

\subsubsection{Externally-driven challenges to SSR}

\subsubsection{Short-term vision}

A first argument contends that international interventions are driven by short-term imperatives, often based on limited capacity and resources allocated to these missions. For instance, Roland Paris argues that if democratization and marketization are sound objectives for war-torn countries, "pushing that process too quickly can have damaging and lasting effects." ${ }^{40}$ Short-term objectives and strategies reduce the ability of international efforts to implement fully SSR programs, to sustain the reform over time, and to ultimately meet their goals. ${ }^{41} \mathrm{He}$ traces this problem back to the limited political will of external stakeholders. Similarly, Mendelson-Forman considers that the premature departure of the UN in Haiti in 2000 undermined the limited but nonetheless significant

Approach to Security Reform in Fragile States," Forum for Development Studies 33, no. 2 (2006): 305-24; Kristi Samuels, "Rule of Law Reform in Post-Conflict Countries: Operational Initiatives and Lessons Learnt" (2006); Chanaa, Security Sector Reform, 33.

${ }^{40}$ Roland Paris, At War's End: Building Peace After Civil Conflict (Cambridge, UK ; New York: Cambridge University Press, 2004), ix.

${ }^{41}$ Michael Brzoska, "Introduction: Criteria for Evaluating Post-Conflict Reconstruction and Security Sector Reform in Peace Support Operations," International Peacekeeping 13, no. 1 (2006): 10; MendelsonForman, "Security Sector Reform in Haiti." 
progress achieved by the new Haitian National Police, created in $1995 .^{42}$ After 2000 , the new police force was unable to face on its own powerful armed groups, which included former members of the armed forces disbanded under international supervision in 19941995. Mendelson-Forman argues: "the Haitian case reinforces the lesson that undertaking security sector reform must be tempered by a vision of long-term investments by both international donors and also by the citizens of the state subject to the reform." ${ }^{43}$

On a related point, Brzoska points to the fact that is it in the interest of international stakeholders to transfer as quickly as possible the responsibility and leadership of the reform process to national players to reduce costs and mitigate risk. However, the emphasis on short-term objectives that facilitates exit and limits resources endowment also undermines external influence on domestic actors and local ownership. ${ }^{44}$ In Afghanistan and Iraq, for instance, international priorities led to a disproportionate emphasis on hard security elements through the training and equipping of state security forces, to the detriment of softer aspects of SSR that requires long-term investment, such as the promotion of good governance, the development of accountability mechanisms, and the defence of human rights. ${ }^{45}$ As a result, SSR is typically narrow, with a focus on components of the state security sector such as the military or the police, and incomplete, as it emphasizes effectiveness without much concern for oversight and accountability. ${ }^{46}$ This has been the case for instance in Colombia, where SSR efforts focused on

\footnotetext{
${ }^{42}$ Mendelson-Forman, "Security Sector Reform in Haiti."

${ }^{43}$ Ibid., 15.

${ }^{44}$ Brzoska, "Introduction," 7.

${ }^{45}$ Sedra, "Security Sector Reform in Afghanistan and Iraq," 8.

${ }^{46}$ Albrecht Schnabel and Albert Born, "Security Sector Reform: Narrowing the Gap between Theory and Practice," SSR Paper (Geneva: The Geneva Centre for the Democratic Control of Armed Forces (DCAF), 2011), 22-26.
} 
modernising the military forces as part of a counter narcotics trafficking strategy, ${ }^{47}$ and in Haiti where the reform of the police has been defined as the upmost priority of successive peace operations, as I will discuss in detail later.

\subsubsection{Coordination and coherence}

A second group of authors considers that the lack of coordination and coherence in the implementation of SSR prevents it from being a truly transformative process. ${ }^{48}$ The absence of consensus about what SSR actually is on the ground and how it should be implemented, divergent perspectives on what should be prioritized, and the general lack of coordination mechanisms between stakeholders affect the ability of these programs to meet their objectives. Michael Brozska highlights how there is actually little knowledge about what should be prioritized and which sequence SSR should follow. ${ }^{49}$ "Contradicting interest, divergent resources endowment and varying levels of expertise among international groups" $" 50$ certainly play a role in the poor implementation of SSR.

According to these authors, coordination between SSR and other programs in multidimensional operations also hampers those reforms. Turf wars within and between sectors in multi-dimensional interventions, conflicting priorities, and silo approaches undermine the implementation and the sustainability of SSR. In post-conflict environments, for instance, coherence between disarmament, demobilisation, and reintegration (DDR) programs and SSR is essential since the two outcomes are mutually

\footnotetext{
${ }^{47}$ Wolf Grabendorff, "Limited Security Sector Reform in Colombia," in Security Sector Reform in Challenging Environments, ed. Hans Born and Albrecht Schnabel (Münster: LIT, 2009), 69-86.

${ }^{48}$ Sedra, "Security Sector Reform in Afghanistan and Iraq"; Brzoska, "Introduction"; Chanaa, Security Sector Reform.

${ }^{49}$ Brzoska, "Introduction."

${ }^{50}$ Ibid., 8.
} 
dependent.$^{51}$ Nevertheless, these linkages are often overlooked in practice.${ }^{52}$ In the case of UN peace operations, there is often competition between the SSR and DDR components since, as part of the Office of Rule of Law and Security Institutions within the DPKO, both rely on the same limited pool of resources. ${ }^{53}$

\subsubsection{National ownership and domestic politics}

SSR failures have also been attributed to the absence of national and local ownership at every stages of the reform process ${ }^{54}$ From that perspective, buy-in by national authorities is not sufficient, and security institutions should respond to the needs and aspirations of the State and its population. To this end, national and local stakeholders should not only agree to SSR programs, but also participate actively to their elaboration and implementation. Considering the limits of international involvement discussed in the previous section, the sustainability of the reforms requires the commitment of national actors to pursue reforms and support their outcomes beyond the withdrawal of international stakeholders. ${ }^{55}$ Timothy Donais highlights for instance how "strong national

\footnotetext{
${ }^{51}$ Véronique Dudouet, Hans J. Giessmann, and Katrin Planta, "From Combatants to Peacebuilders: A Case for Inclusive, Participatory and Holistic Security Transitions," Policy Report (Berghof Foundation, 2012), 1 .

${ }^{52}$ Melanne A. Civic and Michael Miklaucic, eds., Monopoly of Force : The Nexus of DDR and SSR (Washington, DC: National Defense University Press, 2011).

${ }^{53}$ Observation compiled by the author in research notes, New York City, Fall 2013.

${ }^{54}$ Timothy Donais, "Haiti and the Dilemmas of Local Ownership," International Journal 64, no. 3 (2009): 753-73; Daniel Bendix and Ruth Stanley, "Deconstructing Local Ownership of Security Sector Reform: A Review of the Literature," African Security Review 17, no. 2 (2008): 93-104; Laurie Nathan, "No Ownership, No Commitment: Local Ownership of Security Sector Reform: A Guide for Donors" (United Kingdom: University of Birmingham, 2007); Eric Scheye and Gordon Peake, "Unknotting Local Ownership," in After Intervention: Public Security Management in Post-Conflit Societies. From Intervention to Sustainable Local Ownership, ed. Anja H. Ebnöther and Philipp H. Fluri (Vienna: National Defense Academy and Bureau for Security Policy, 2005).

${ }^{55}$ Mendelson-Forman, "Security Sector Reform in Haiti."
} 
leadership and deep societal engagement" are associated with successful peace-building initiatives, such as in post-Apartheid South Africa. ${ }^{56}$

Domestic dynamics and their impact on SSR programs have recently attracted the attention of researchers. Ursula Schroeder, Fairlie Chappuis, and Deniz Kocak discuss how externally driven SSR programs interact with domestic dynamics to create hybrid forms of security governance. ${ }^{57}$ Domestic actors usually pick and choose between the different standards advanced and promoted by SSR, leading to systems of security governance mixing international and local structures, norms, and practices. As Charles T. Call points out in the case of El Salvador, developing formal structures and institutions does not necessarily lead to a change in culture and practices..$^{58}$

Research also highlights how the attitude of national elites toward SSR influences the success of those reforms. SSR can alter power distribution between groups and undermine the power base of key political actors. Consequently, these actors are unlikely to support the reform process unless the right incentives are put in place ${ }^{59}$ In a similar vein, Louis-Alexandre Berg argues that the distribution of power between political elites influences the SSR process.$^{60}$ Reforms are more likely when leaders rely on a broad and/or fragmented coalition, and cannot easily access sources of revenue. SSR is harder in contexts where ruling elites rely on a narrow political base and have discretionary power over the use of financial resources. Strong neo-patrimonial regimes, which have a

\footnotetext{
${ }^{56}$ Timothy Donais, "National Ownership and Post-Conflict Peace Building: From Principle to Practice," Policy Brief (Waterloo (On): Centre for International Governance Innovation, June 2014), 2.

${ }^{57}$ Ursula C. Schroeder, Fairlie Chappuis, and Deniz Kocak, "Security Sector Reform and the Emergence of Hybrid Security Governance," International Peacekeeping 21, no. 2 (March 15, 2014): 214-30, doi:10.1080/13533312.2014.910405.

${ }^{58}$ Charles T. Call, "Democratisation, War and State-Building: Constructing the Rule of Law in El Salvador," Journal of Latin American Studies 35, no. 4 (2003): 827-62.

${ }^{59}$ Brzoska, "Introduction," 8.

${ }^{60}$ Berg, "Guns, Laws and Politics."
} 
narrow base and where leaders have strong discretionary power, are therefore less likely to reform their security institutions, despite international pressures.

These elements certainly identify important challenges to SSR. Advocates of the state-building paradigm have discussed these themes at length. However, the lack of systematic consideration for non-elite groups and the local community has been increasingly criticised. Those actors are important in fragile societies, where the role, power, and capacity of central security institutions are limited and likely to remain so. Given that most states outside of the Western hemisphere do not actually correspond at all to the Weberian ideal-type, a narrowly state-centric SSR looks unlikely to succeed in the short or medium term. Scholars and policy-makers preoccupied with ensuring an adequate modicum of public security in the meantime increasingly recognise the need to expand SSR beyond the State.

The authors cited in this section do not necessarily reject this critique. Mark Sedra, for one, works on the development of a second-generation SSR approach. ${ }^{61}$ Nonetheless, his vision ultimately remains state-centric. Referring to the work of Mark Knight, ${ }^{62}$ he considers that "to understand SSR, it is critical to recognize its Western liberal pedigree and its intrinsic links to wider processes of democratization and liberal peace-building." ${ }^{\prime 3}$ Elsewhere in the literature however, there has been a clear turn since the late 2000s toward a more critical approach to SSR in fragile states with a specific emphasis on questions of governance beyond statehood, informal security arrangements, and non-state

\footnotetext{
${ }^{61}$ Mark Sedra, "Towards Second Generation Security Sector Reform," in The Future of Security Sector Reform, ed. Mark Sedra, Centre for International Governance Innovation (Waterloo (On), 2010), 102-16.

${ }^{62}$ M. Knight, "Security Sector Reform, Democracy, and the Social Contract: From Implicit to Explicit," Journal of Security Sector Management 7, no. 1 (2009): 20.

${ }^{63}$ Sedra, "Towards Second Generation Security Sector Reform," 104.
} 
security providers. This new trend contributes to a reflection on SSR's goals and strategies, challenging to some extent the notion that state security provision is the only solution to insecurity and violence.

\subsection{Reconceptualising the security sector of fragile states}

After its formulation in the late 1990s, SSR became synonym for state building, and emphasized the need to (re)establish the State's monopoly over the means of violence as a technical problem. ${ }^{64}$ However, due to setbacks and lack of results on the ground, the academic and policy communities, including the UN, the OECD, DFID, and the U.S. Agency for International Development (USAID), increasingly recognized the political nature of SSR and the need to consider the role of non-state, informal, and local actors and institutions in security and justice delivery. ${ }^{65}$ Nonetheless, most efforts on the ground remained state-centric and focused on the technical and administrative aspects of the reform process. ${ }^{66}$ For instance, a study on aid effectiveness in Afghanistan reveals "a shared belief among all respondents that a lack of information on the political economy of fragile states is one of the greatest challenges international actors face in the field."67

The scholarship on SSR has grown increasingly critical of a vision that prioritizes the reinforcement of state institutions and tends to leave aside other sources of power and authority in societies targeted by state-building interventions. Research currently emphasizes the role of local agency and other domestic political factors in the design and

\footnotetext{
${ }^{64}$ Paul Jackson, "Security Sector Reform and State Building," Third World Quarterly 32, no. 10 (2011): 1803-1822.

${ }^{65}$ Helene Maria Kyed, “Legal Pluralism and International Development Interventions,” Journal of Legal Pluralism and Unofficial Law 63 (2011): 2.

${ }^{66}$ Peter Albrecht and Helene Maria Kyed, "Local Actors in Security and Justice Programming," in Handbook of International Security and Development, ed. Paul Jackson (Cheltenham, UK ; Northampton, MA, USA: Edward Elgar Pub, 2015), 252.

${ }^{67}$ Christoph Zürcher, "Conflict, State Fragility and Aid Effectiveness: Insights from Afghanistan," Conflict, Security \& Development 12, no. 5 (December 1, 2012): 473, doi:10.1080/14678802.2012.744180.
} 
the implementation of SSR. The literature questions key assumptions of the state-building paradigm, doubting the relevance and applicability of the Weberian model to fragile states. This section introduces some of the key critiques of state-centric SSR. I first discuss the concept of hybrid political order, which is central to the dominant critiques of SSR's state-centrism, before turning to security and justice delivery beyond the State.

\subsubsection{Hybrid political orders}

Research on the hybrid nature of governance in post-conflict countries and fragile societies has grown since the early 2000s. ${ }^{68}$ Critiques of the state-building paradigm propose to conceive fragile states as hybrid political orders. In these polities, various spheres of power and authority interact or evolve in parallel to produce order. ${ }^{69}$ According to Peter Albrecht, systems of governance in fragile states are composed of both central state institutions and local actors: "it is [...] a system of mutually reinforcing, beneficial and sometimes antagonistic relationships, partnerships and associations, which play a central role in constituting public service delivery."70 This group of authors challenges the notion that states considered fragile are failed versions of the Weberian ideal-type. They rather argue that hybrid political orders constitute another forms of

\footnotetext{
${ }^{68}$ See, for example, Mukhopadhyay, Warlords, Strongman Governors, and the State in Afghanistan; Kate Meagher, "The Strength of Weak States? Non-State Security Forces and Hybrid Governance in Africa," Development and Change 43, no. 5 (2012): 1073-1101, doi:10.1111/j.1467-7660.2012.01794.x; Kyed, "Legal Pluralism and International Development Interventions"; Baker, "The Future Is Non-State"; Louise Wiuff Moe, "Hybrid and 'Everyday' Political Ordering: Constructing and Contesting Legitimacy in Somaliland," Journal of Legal Pluralism and Unofficial Law, no. 63 (2011): 143-77; Boege et al., "On Hybrid Political Orders and Emerging States"; Kevin P. Clements et al., "State Building Reconsidered: The Role of Hybridity in the Formation of Political Order," Political Science 59, no. 1 (June 1, 2007): 45-56. ${ }^{69}$ Volker Boege, M. Anne Brown, and Kevin P. Clements, "Hybrid Political Orders, Not Fragile States," Peace Review 21, no. 1 (March 1, 2009): 17, doi:10.1080/10402650802689997.

${ }^{70}$ Peter Albrecht, "Building on What Works: Local Actors and Service Delivery in Fragile Situations," in Handbook of International Security and Development, ed. Paul Jackson (Cheltenham, UK ; Northampton, MA, USA: Edward Elgar Pub, 2015), 291.
} 
polity, resulting from specific structural, cultural, and economic factors. ${ }^{71}$ Under these conditions, the central State has rarely sought to expand its authority throughout its territory, as effective local control is not necessary to the political survival of elites.

In hybrid political orders, as a result, public goods such as security are often produced and administrated by non-state actors and informal arrangements outside of the State's reach. Sometimes, non-state actors fill the space left vacant by a receding or "restructured" State. Other times, the State has never been present in the first place and local order is produced through more or less formalized arrangements administrated by local actors. Elsewhere, the State and non-state actors interact together in the delivery of services and the production of order.

Conceiving fragile states as hybrid political orders enable us to better understand how multiple actors, state and non-state, can produce public order and provide security through more or less formal arrangements. It opens the black box of state fragility, and allows us to consider the different mechanisms through which order is produced and services are provided.

\subsubsection{Security and justice provision in hybrid political orders}

Both state and non-state actors can bear authority and contribute to the production of public order in fragile states. Non-state actors (including but not limited to militias,

\footnotetext{
${ }^{71}$ See, for example, Dipali's discussion on the role of the central state in Afghanistan in the $20^{\text {th }}$ century: Dipali Mukhopadhyay, "Disguised Warlordism and Combatanthood in Balkh: The Persistence of Informal Power in the Formal Afghan State," Conflict, Security \& Development 9, no. 4 (December 2009): 535-64, doi:10.1080/14678800903345812; Herbst present a strong argument regarding the absence of Tilly's state formation process in Africa: Jeffrey Herbst, States and Power in Africa, 1st ed. (Princeton, N.J: Princeton University Press, 2000); Douglass North points out to the role of institutions and path-dependency in economic development: Douglass C. North, "Institutions," Journal of Economic Perspectives 5, no. 1 (1991): 97-112; several other authors make related argument, such as Séverine Autesserre, Peaceland: Conflict Resolution and the Everyday Politics of International Intervention (Cambridge University Press, 2014); Andersen, "Security Sector Reform and the Dilemmas of Liberal Peacebuilding"; Baker, MultiChoice Policing in Africa; Scheye and Peake, "Unknotting Local Ownership."
} 
vigilante groups, and gangs) can impose themselves due to their ability to use coercive force. For example, drug traffickers in Rio de Janeiro have managed to gain and maintain control over favelas through flexible networks with community leaders and local state authorities. $^{72}$ In Afghanistan, warlords turned governors used formal and informal channels to govern and control economic activities, both legal and illegal, in their province. ${ }^{73}$ In Western Africa, in spaces where state institutions are weak, criminal organisations "create[d] their own more powerful and efficient system of constraint on violence." ${ }^{74}$ The same is also true in certain parts of Mexico, where cartels provide protection to ensure the sustainability of their economic activities. ${ }^{75}$ In Nigeria, youth groups provide security and justice where the state would not do so. ${ }^{76}$ In Jamaican cities, criminal actors fulfill state functions and compose a complex system of governance alongside politicians, police, and bureaucrats. ${ }^{77}$ Those examples suggest not only that non-state actors can produce public order and provide certain services to the population, but also that non-state and informal governance is widespread.

Additionally, where the State is unable or unwilling to provide such services, nonstate actors and informal arrangements may be the only form of security and justice available. Bruce Baker suggests that non-state and informal security and justice is often

\footnotetext{
${ }^{72}$ Enrique Desmond Arias, Drugs and Democracy in Rio de Janeiro: Trafficking, Social Networks, and Public Security (Chapel Hill: University of North Carolina Press, 2006).

${ }^{73}$ Mukhopadhyay, Warlords, Strongman Governors, and the State in Afghanistan.

${ }^{74}$ William Reno, "Understanding Criminality in West African Conflicts," International Peacekeeping 16, no. 1 (February 1, 2009): 55, doi:10.1080/13533310802485542.

${ }^{75}$ Stergios Skaperdas, "The Political Economy of Organized Crime: Providing Protection When the State Does Not," Economics of Governance 2, no. 3 (November 2001): 173-202, doi:10.1007/PL00011026.

${ }^{76}$ Meagher, "The Strength of Weak States?"

${ }^{77}$ Rivke Jaffe, "The Hybrid State: Crime and Citizenship in Urban Jamaica," American Ethnologist 40, no. 4 (November 1, 2013): 734-48, doi:10.1111/amet.12051.
} 
the only form of order known to marginalised populations. ${ }^{78}$ People can also choose to turn to non-state actors if they consider them more powerful and/or effective than state authorities. ${ }^{79}$ The degree to which non-state actors provide effective security or adopt predatory behaviours certainly varies, and it is essential not to romanticize the local and the informal. ${ }^{80}$ Yet in one case or the other, non-state actors influence the level of public order in a given space based on their ability to claim control over the means of violence.

In summary, critiques of the state-building paradigm consider that a generalized lack of consideration for the hybrid nature of governance in fragile states explains at least in part the lack of success of SSR. The literature on hybrid political order and governance beyond the State argues that non-state actors and informal arrangements play a key role in the production of public order in a majority of countries outside the western hemisphere. ${ }^{81}$ Where the State is absent or too weak to impose itself, a wide variety of actors can be present and provide some form of security, which organizes daily life and contributes to the production of public order. The resulting hybrid orders are not necessarily failed Weberian States, but rather alternative forms of polity. State-centric SSR is ill suited to address issues related to security delivery and public order in these hybrid polities.

\subsection{SSR in hybrid political orders}

\footnotetext{
${ }^{78}$ Baker, Multi-Choice Policing in Africa.

${ }^{79}$ Ibid.; Boege et al., "On Hybrid Political Orders and Emerging States"; Clements et al., "State Building Reconsidered"; Andersen, "When Security Is Found Beyond the State."

${ }^{80}$ See, for example, Schroeder and Chappuis, "New Perspectives on Security Sector Reform," 137; Meagher, "The Strength of Weak States?"; William Reno, "Protectors and Predators: Why Is There a Difference among West African Militias?," in Fragile States and Insecure People? Violence, Security and Statehood in the Twenty-First Century, ed. Louise R. Andersen, Bjørn Møller, and Finn Stepputat, Palgrave Studies in Governance, Security and Development (New York: Palgrave MacMillan, 2007).

${ }^{81}$ Albrecht and Kyed, "Local Actors in Security and Justice Programming," 248; OECD-DAC, The OECD DAC Handbook on Security System Reform (SSR): Supporting Security and Justice.
} 
Debates over the hybrid nature of governance and order in fragile states have informed the recent scholarship on SSR. In their edited volume on the political economy of state building, Mats Berdal and Dominic Zaum focus on the "impact of outside interventions on the complex relationship, in terms of power and influence, between formal and informal political and economic actors, groups and networks within war-torn and conflict affected societies." ${ }^{82}$ In 2014, the journal International Peacekeeping published a special issue on the role of local agency and domestic politics in SSR. The editors of this special issue argue: "closer attention to the role and influence of existing systems of governance in recipient states is thus necessary to explain the consequences of international intervention in the security field." ${ }^{83}$ More recently, Peter Jackson edited the Handbook of International Security and Development, which discusses at length the evolution of SSR, questions of local ownership, and hybrid governance. ${ }^{84}$ Among others, these recent publications highlight the importance of the local and the profoundly political nature of SSR. Examples on which these authors build their argument include Afghanistan, Timor-Leste, Sierra Leone, Iraq, Burundi, and Haiti.

A shared finding of these publications is that the international community lacks strategies and tools to engage with non-state actors and informal arrangements. When non-state actors and informal arrangements are taken into consideration, it is often from the standpoint of their integration into the State's structure. ${ }^{85}$ Actors and arrangements

\footnotetext{
${ }^{82}$ Mats Berdal and Dominik Zaum, eds., Political Economy of Statebuilding; Power after Peace, Routledge, Routledge Studies in Intervention and Statebuilding (London ; New York, 2013), 1.

${ }^{83}$ Schroeder and Chappuis, "New Perspectives on Security Sector Reform," 139.

${ }^{84}$ Paul Jackson, ed., Handbook of International Security and Development (Cheltenham, UK ; Northampton, MA, USA: Edward Elgar Pub, 2015).

${ }^{85}$ Bruce Baker, "Justice and Security Architecture in Africa: The Plans, the Bricks, the Purse and the Builder," Journal of Legal Pluralism and Unofficial Law 63 (2011): 25-48.
} 
that do not fit well in internationally driven reform strategies tend to be ignored or discarded. In fact, local agency is often presented either as a deficit or a problem to be solved ${ }^{86}$ Hence, the end game remains the Weberian ideal-type.

By contrast, advocates of hybrid approaches consider that "it is this empirical reality of an integrated system of actors, who draw their authority from a variety of sources, that should be taken as point of departure in program design and implementation. ${ }^{87}$ Indeed, the design of SSR and its implementation should be based on an empirical analysis of the actors and arrangements that constitute the main channels through which security is provided and order is produced in fragile states.

Effective and sustainable SSR strategies require a better understanding of how reforms affect authority and power relations in fragile states. Successful SSR requires more flexible relations with non-state actors and informal arrangements, including in some cases those that are considered illegitimate or criminal by external stakeholders. ${ }^{88}$ However, few analytical tools have been proposed so far to make sense of how SSR affects security delivery and the production of order in a specific context. Practitioners and researchers must be able to make sense of who and what constitute a hybrid political order to better understand the mechanisms through which these reforms can improve security delivery, and ultimately make people feel safer. Interactions between the state and the non-state, the formal and the informal, and domestic and international all have implications for SSR.

\footnotetext{
${ }^{86}$ Schroeder and Chappuis, "New Perspectives on Security Sector Reform," 137.

${ }^{87}$ Albrecht, "Building on What Works: Local Actors and Service Delivery in Fragile Situations," 291.

${ }^{88}$ Reno, "Understanding Criminality in West African Conflicts," 58.
} 
In a theory-building effort, the objective of this dissertation is to develop more systematic tools to understand how public order is produced and security is managed in fragile states, and how SSR affects both endeavours. In the next chapter, I develop the concept of public order regime to make sense more systematically of the complex constellation of actors that characterizes public ordering and security provision in fragile states. Through this framework, it is then easier to understand the consequences of SSR on public order in fragile settings, and why, so often, these reforms fail to control violence and make people safer. 


\section{Chapter: Introducing the Public Order Regime Framework and its}

\section{Implications for SSR in Fragile States}

In fragile states where the central governing authorities do not successfully claim a monopoly on the use of coercive force, security sector reform often fails to improve public order and control violence. As an institutional reform process, SSR seeks to expand state authority to improve basic security provision in accordance with democratic norms and principles of good governance ${ }^{89}$ However, these reforms usually remain statecentric and ignore a large part of the mechanisms through which public order is effectively produced in those countries. Where the State is unable or unwilling to formally impose its authority, state actors often act informally and non-state coercive actors have emerged to claim some control over the means of violence, contributing to the production of public order and influencing the daily life of communities. Together with the State, these various actors constitute a pluralist public order regime, wherein multiple coercive actors produce public order through formal and informal means. When applied to this kind of regimes, reforms that focus only on formal activities by state security agencies are unlikely to improve public order. I argue that state-centric SSR has disruptive consequences on the production of public order in fragile states and can potentially lead to conflict over the means of violence between coercive actors, ultimately undermining public order and increasing violence.

In this chapter, I propose a new theoretical approach to (1) better understand how public order is produced in fragile states, and (2) why state-centric SSR often fails to

\footnotetext{
${ }^{89}$ OECD-DAC, The OECD DAC Handbook on Security System Reform (SSR): Supporting Security and
} Justice. 
improve public order. The first section of the chapter describes how public order is actually produced. I introduce the concept of public order regime and outline its implications for fragile states. In the second section of the chapter, building on insights from the literature on legal pluralism, I propose some key mechanisms to explain how SSR affects the production of public order in fragile states. Those propositions, which are the core of this dissertation, will be probed in the following chapters. I argue that SSR through state expansion has disruptive consequences for PORs, which can create resistance and potentially create conflict, undermining both the level of public order and the sustainability of the SSR process itself. As currently conceived, state-centric SSR in fragile states is unlikely to improve public order and may actually increase violence.

\subsection{Public order in fragile states}

\subsubsection{Public order}

The concept of public order is usually linked to the notion of state sovereignty understood in Weberian terms. A State exists "insofar as its administrative staff successfully upholds the claim to the monopoly of the legitimate use of physical force in the enforcement of its order." ${ }^{, 90}$ For example, in its guiding principles for stabilization and reconstruction interventions, the United States Institute of Peace defines public order in the following terms:

A condition characterized by the absence of widespread criminal and political violence $[\ldots]$ without public order, people will never build confidence in the public security system and will seek security from other entities like militias and warlords. [...] Public order is the domain of police and other policing agencies,

\footnotetext{
${ }^{90}$ Max Weber, Economy and Society: An Outline of Interpretive Sociology (Berkeley: University of California Press, 1978), 54.
} 
courts, prosecution services, and prisons - all of which make up the criminal justice system. $^{91}$

According to this definition, the absence of functioning state-based public security and justice institutions leads to political violence, crime, and public disorder. It also implies that the provision of security and other services to the population by non-state actors is a consequence of public disorder, rather than an alternative source of public order. This conception of public order substantiates the democratic peace theory, which poses democratisation as an essential element to a lasting and stable peace in postconflict and fragile contexts. $^{92}$

The Oxford English Dictionary proposes a less state-centric definition of public order: "[a] state in which the laws and rules regulating the relationship of individuals to the community, and the public conduct of members within a community, are maintained and observed and authority is obeyed." 93 Here, the level of public order depends on the extent to which rules and norms are maintained and authority is not contested, rather than on who actually acts as an authority figure and determines the normative framework that controls relations and behaviours in the community.

This broader definition is more useful to understand how public order is effectively produced in fragile states for two main reasons. First, the definition entails that public order is a continuum rather than a dichotomy. Higher levels of public order simply

${ }^{91}$ United States Institute of Peace, "Public Order," United States Institute of Peace, N.D., http://www.usip.org/guiding-principles-stabilization-and-reconstruction-the-web-version/7-rule-law/publicorder.

${ }^{92}$ Bruce Russett, Grasping the Democratic Peace: Principles for a Post-Cold War World (Princeton University Press, 1994); Nils Petter Gleditsch, "Peace and Democracy," in Encyclopedia of Violence, Peace, and Conflict, ed. Lester Kurtz, vol. 1, 1999, 643-52; Paris, At War's End.

${ }^{93}$ Oxford English Dictionary, “Order, N.," OED Online (Oxford University Press, N.D.). 
correspond to a stable environment where there is a broad understanding of the rules and norms regulating daily life, and sources of authority are recognized and respected.

Second, this definition also leaves open the possibility that non-state actors could produce public order. In fragile states, non-state actors such as clan leaders, religious figures, customary authorities, or even gangs and warlords can control the behaviours of individuals and communities by imposing and enforcing rules, provide security, manage conflicts, and prevent or at least control violence. Furthermore, even if state services are made available, people can still choose to rely on non-state public ordering mechanisms if they consider them more effective and/or trustworthy. ${ }^{94}$ Public order can therefore be produced by a wide range of coercive actors who have incentives to do so. It is not the preserve of the State.

The focus of this dissertation is on coercive actors who can and are willing to directly use violence or its threat to control spaces and people living in them. I use "coercive actors" here instead of the more generic "armed actors" to emphasize that they seek to control behaviours and influence public order through the use of violence or its threat. From that standpoint, their use of arms is accessory, not inherent to their identity. Coercive actors can associate themselves with other actors such as customary figures or religious leaders to improve their position in the authority structure of the community, for example..$^{95}$ Conversely, other actors can delegate authority to coercive ones to ensure, for instance, their survival and maintain their advantageous position inside the community.

\footnotetext{
${ }^{94}$ Clements et al., "State Building Reconsidered."

${ }^{95}$ See Boege et al., "On Hybrid Political Orders and Emerging States."
} 
Interactions between Islamic figures and jihadists groups in Northern Mali illustrate well those dynamics. In the early 2000s, jihadist groups used economic resources acquired through criminal activities to gain influence in local communities. ${ }^{96}$ In an environment where the power of traditional authorities was quickly eroding but had yet to be replaced by the State, these newly, wealthy, and powerful actors were quickly able to fill the growing authority gap. At first, they engaged economically with villages, buying food and other supplies from them. They increasingly gained influence with local people through marriage and the provision of basic goods such as medicines and telephone cards. They also supported marabouts - local Islamic figures - in and around Timbuktu. Doing so, over time, they gained authority, which enabled them to increasingly influence the rules and norms regulating the communities' daily life. They managed to impose their particular vision of Islam and establish a territorial base to conduct operations in the region, pursuing their objective of forming a unified Islamist Maghreb. This example illustrates how non-state actors who successfully claim some control over the means of violence can shape public order and influence the daily life of communities by imposing and/or associating themselves with other authority figures. In such cases, the result is a certain form of public order, not a state of relative disorder.

\subsubsection{Public order regimes}

To better understand how different configurations of authority and power shape public order, I propose the concept of "public order regime" (POR). A POR is an institutional arrangement that governs the production of public order in a given space by

\footnotetext{
${ }^{96}$ Morten Bøås and Liv Elin Torheim, "The Trouble in Mali-corruption, Collusion, Resistance," Third World Quarterly 34, no. 7 (2013): 1287.
} 
actors who, formally or informally, define and enforce rules and norms regulating some aspects of a community's daily life. ${ }^{97}$ A POR includes all the coercive actors who engage in formal or informal public ordering activities. The level of public order produced in a POR is largely influenced by interactions between coercive actors claiming some control over the means of violence and their relative ability to impose themselves in the space controlled by the regime as a whole.

\subsubsection{Monist and pluralist public order regimes}

A monist POR is composed of a single coercive actor, usually the State. Such a monist regime is an ideal-type that corresponds to the Weberian State. In a monist regime, there is no competition between coercive actors, and the norms and rules regulating behaviours are defined and enforced by a single actor. Contemporary western democracies tend towards this ideal-type, and examples of monist regimes can be found at the subnational level. Monism also constitutes the ultimate objective of the statebuilding paradigm, and it has guided the design, implementation, and evaluation of SSR.

A pluralist POR is composed of several coercive actors. The degree of pluralism in a POR increases along with the number of such actors. In a typical pluralist POR, a variety of coercive actors claims some control over the means of violence and contribute to the production of public order, typically on the basis of different sets of rules and norms. Fragile states are usually characterized by these PORs since the State's security agencies are unable or unwilling to project their authority throughout the territory and provide

\footnotetext{
${ }^{97}$ The type of behaviours controlled by coercive actors varies based on the claim successfully made by those actors. It usually includes public behaviours, such as who can access a given community or who can engage in specific economic activities. Control can also expand beyond the strictly public sphere to include some elements of the private sphere of life. Domestic violence is an example of private behaviour that can potentially be regulated by coercive actors.
} 
public order to the entire population. When the State fails to provide security and justice to its population, people usually turn to other forms of authority for security.

In any regime, violence becomes a mean to "establish, maintain and contest" regimes and social order. ${ }^{98}$ According to Goldstein and Arias, violent pluralism is explained by the fact that "order (and/or disorder) is created through the interaction of multiple violence actors, both within and without the state, a situation that characterizes many political regime in the developing world today." ${ }^{.99}$ Nonetheless, pluralism is not always violent. Some pluralist regimes - with or without state actors - can ensure a high level of public order, control violence, and be relatively stable. As long as authority is obeyed and rules and norms are maintained, the degree of formality of the normative framework that pluralist PORs impose does not matter much to their efficacy or, when they produce substantive social benefits to the population, to their legitimacy.

\subsubsection{The level of public order}

The level of public order produced by the POR depends on the relative ability of coercive actors to claim control over the means of violence and how they interact with one another. In a monist regime, the level of public order tends to be relatively higher since there is no potential for competition and conflict between coercive actors. Furthermore, the normative framework tends to be known and recognized more easily than in a pluralist regime since there is less potential for normative gaps and overlaps.

\footnotetext{
${ }^{98}$ Daniel M. Goldstein and Enrique Desmond Arias, Violent Democracies in Latin America (Duke University Press, 2010), 5.

${ }^{99}$ Ibid., 10.
} 
In contrast, the level of public order in a pluralist POR tends to be lower due to competing claims between coercive actors. Those claims can increase tensions and competition between actors, potentially resulting in conflict and higher levels of violence. For instance, coercive actors in a pluralist POR are more likely to signal their intentions and reassert their authority through violence. Moreover, pluralism creates opportunities for forum shopping where individuals in the space controlled by the regime can opt for different rules and/or sources of authority. We should expect that the level of public order decreases as the number of coercive actors with competing claims increases. However, coercive actors can also have complementary claims and evolve in parallel. In that case, there is less potential for tensions, frictions, and resulting violence. Nonetheless, in general and over the long run, pluralist regimes probably still represent sub-optimal arrangements. In Western Europe, the emergence of Westphalian States and the progressive establishment of PORs tending towards monism were accompanied by a general decline in the level of social violence..$^{100}$

\subsubsection{The institutional landscape of public order regimes}

A typical pluralist POR is composed of state and non-state coercive actors engaging in more or less formal public ordering activities. It is important to note that where state authority is limited, the distinction between state and non-state actors is not always

\footnotetext{
${ }^{100}$ Charles Tilly, Coercion, Capital and European States: AD 990 - 1992, Revised (Hoboken, N.J.: WileyBlackwell, 1992).
} 
dichotomous. As nicely put by Lily L. Tsai, "there is a grey area rather than a distinct line between what is state and what is non state."101

The distinction between informal and formal public ordering is clearer: formal public ordering corresponds to the existence of an explicit legal framework, such as the State's legislative framework, religious codes, or explicit customary arrangements. Formal public ordering supposes the existence of clear and codified rules, promulgated by a recognized source of authority. ${ }^{102}$ For instance, police forces engage into formal public ordering when they base their coercive action on the legislative corpus of the State, a recognized source of authority. Death squads composed of off-duty police officers who target specific groups and engage in extrajudicial violence do so based on non codified rules that are usually self-promulgated. The formalization of public order means that rules are codified and associated to a specific coercive actor. An argument can be made for instance that long-existing extortion rackets are to a certain extent formalized since people obeying under them are aware of how they must behave to avoid retaliation.

Table 1 maps out the institutional landscape of PORs. A monist regime, which constitutes an ideal-type on which SSR and broader state-building interventions are based, would be exclusively confined to quadrant IV of the table, whereas the relevance of any component of the other quadrants defines a degree of pluralism.

\footnotetext{
${ }^{101}$ Lily L. Tsai, "Friends or Foes? Nonstate Public Goods Providers and Local State Authorities in Nondemocratic and Transitional Systems," Studies in Comparative International Development 46, no. 1 (January 20, 2011): 67, doi:10.1007/s12116-010-9078-4.

102 The literature on the rule of law makes a distinction between formal and substantive conceptions of the rule of law. Here, I am only concerned by the formal aspect of public ordering, not by its substantive character, which would refers to the content of the rules and norms regulating individual behaviours inside the public order regime. For a detailed discussion of the distinction between formal and substantive conception of the rule of law, see Paul Craig, "Formal and Substantive Conceptions of the Rule of Law: An Analytical Framework," Public Law, 1997, 467-487.
} 
Table 1 Public order regime framework

\begin{tabular}{|c|l|l|}
\hline \multirow{5}{*}{ Non-state Actors } & \multicolumn{1}{|c|}{ Informal Public Ordering } & \multicolumn{1}{c|}{ Formal Public Ordering } \\
\cline { 2 - 3 } & \multicolumn{1}{|c|}{ Quadrant I } & \multicolumn{1}{c|}{ Quadrant II } \\
\hline \multirow{5}{*}{ State Actors } & $\begin{array}{l}\text { Political armed groups } \\
\text { Popular justice (lynching) }\end{array}$ & $\begin{array}{l}\text { Customary arrangements } \\
\text { Religious figures } \\
\text { Community organisations and } \\
\text { leaders }\end{array}$ \\
\hline & $\begin{array}{l}|c| \\
\text { Militias } \\
\text { Paramilitary groups } \\
\text { Death squads } \\
\text { Shadow state }\end{array}$ & $\begin{array}{l}\text { Police forces } \\
\text { Armed forces } \\
\text { Intelligence services } \\
\text { Justice system }\end{array}$ \\
\hline
\end{tabular}

Table 1 also presents different types of coercive actors and institutions that might engage in public ordering. The presence and relative importance of components from the different quadrants will vary from one regime to the other. The combination of elements associated with various quadrants makes it possible to characterize any potential POR and to situate concrete cases in the conceptual map defined by the matrix.

For instance, contemporary western democracies show some degree of pluralism despite the assumed monopoly of state security agencies over the means of violence. While state formal public ordering is dominant, non-state actors engaging in formal public ordering remains an important phenomenon. In Canada, the number of private security agents largely exceeds the number of police officers. ${ }^{103}$ Informal public ordering by criminal groups also exists in western countries. While it remains marginal, the role of criminal actors regulating neighbourhoods, prisons, and informal markets has been

\footnotetext{
${ }^{103}$ In 2006 in Canada, there were approximately 102,000 private security personnel in comparison to 68,000 police agents. See Geoffrey Li, "Private Security and Public Policing" (Statistics Canada, March 12, 2009), http://www.statcan.gc.ca/pub/85-002-x/2008010/article/10730-eng.htm.
} 
extensively documented. ${ }^{104}$ Besides, in strong but corrupt states, such as Russia, ${ }^{105}$ informal public ordering by state actors plays a more significant role, and is possibly dominant.

Hence, pluralist regimes are common and might well be prevalent, even in western democracies. Monist PORs are an ideal-type toward which western developed countries aim, but a certain degree of pluralism usually subsists in these states as well, showing clearly that pluralist PORs are compatible with a high level of public order. The next section discusses PORs in fragile states and provides concrete examples of pluralist PORs.

\subsubsection{Public order regimes in fragile states}

The concept of fragile states has attracted a lot of attention in policy and academic circles. ${ }^{106}$ However, there is still no consensus on what constitutes a fragile state. For the sake of clarity and simplicity, fragile states are conceived here as countries where the central governing agencies have limited capacities and do not exercise an effective monopoly on the use of coercive force. As a consequence, there are spaces where the State is either absent or too weak to impose itself through formal means. In such spaces, state actors often act informally and non-state coercive actors engage in formal and

\footnotetext{
${ }^{104}$ On the role and place of informal and criminal networks in public ordering, see, for example: Jill Leovy, Ghettoside: A True Story of Murder in America (New York: Spiegel \& Grau, 2015); David Skarbek, The Social Order of the Underworld: How Prison Gangs Govern the American Penal System, 1 edition (Oxford: Oxford University Press, 2014); Sudhir Venkatesh, Off the Books: The Underground Economy of the Urban Poor, First Edition edition (Cambridge, MA: Harvard University Press, 2009).

${ }^{105}$ Mark Levin and Georgy Satarov, "Corruption and Institutions in Russia," European Journal of Political Economy 16, no. 1 (March 2000): 113-32, doi:10.1016/S0176-2680(99)00050-6.

${ }^{106}$ Rotberg, "The Failure and Collapse of Nation-States; Breakdown, Prevention and Repair"; Rotberg, State Failure and State Weakness in a Time of Terror; Jean-Germain Gros, "Towards a Taxonomy of Failed States in the New World Order: Decaying Somalia, Liberia, Rwanda and Haiti," Third World Quarterly 17, no. 3 (September 1, 1996): 455-71.
} 
informal public ordering. Based on this definition, PORs in fragile states are always pluralist. However, not all pluralist PORs are fragile.

\subsubsection{Implications for public order}

Fragile states vary a lot based on the relative weight of state and non-state actors as well as the degree of formalization of public ordering mechanisms. However, they do share some characteristics. First, non-state public ordering tends to gain in importance where the State is weak or absent, and where non-state actors have an incentive to produce public order. Their relative importance varies from one regime to another, based on their capacity to claim control over the means of violence, and their willingness to effectively produce public order.

Second, the formal role of state agencies tends to be limited. Non-state actors can produce public order through more or less formal means, and state agencies can engage in informal forms of public ordering. Coercive actors only produce public order where they have an incentive to do so. In this context, public ordering gaps are likely due to the incentives faced by coercive actors or the lack thereof. As a consequence, PORs in fragile states also tend to be incomplete: limited resources and lack of incentives to produce public order throughout the regime implies that some activities and behaviours may not be regulated. Pluralism and incompleteness make fragile states more vulnerable to disruption through external shocks for example. Nonetheless, they typically do manage to produce a certain level of public order and are not necessarily dysfunctional.

\subsubsection{Examples of public order regimes in fragile states}


The structure of a pluralist POR varies based on the relative weight of its components and how they interact with one another. To better illustrate my point, I present some illustrations of pluralist PORs in fragile states. These examples highlight how pluralist regimes, while being often fragile and incomplete, are not necessarily violent and dysfunctional.

\subsection{Pluralist PORs dominated by non-state actors}

During episodes of state collapse where the central governing authorities are extremely weak and unable to claim a monopoly on the use of coercive force, state public ordering is very limited and non-state actors typically dominate the POR. Through the use of violence, criminal organizations, warlords, or armed political groups can engage in public ordering and successfully claim some control over large areas. ${ }^{107}$ In Bosnia for instance, the UN had to negotiate with powerful criminal actors to access certain zones and deliver humanitarian assistance. ${ }^{108}$ Once an agreement was reached, humanitarian activities followed their course without disruption from the criminal organization in control.

At the end of the 1990s during the second Congolese civil war, the Rassemblement congolais pour la démocratie - Mouvement de libération (RDC-ML) deeply affected the structure of the existing POR in the North Kivu province where the State was virtually

\footnotetext{
${ }^{107}$ Robert I. Rotberg argues that failed states are characterized by anarchy and disorder. Equating state collapse to an authority and security vacuum, Rotberg overlooks the possibility of pluralist public order regimes largely dominated by non-state informal public ordering. See Rotberg, "The Failure and Collapse of Nation-States; Breakdown, Prevention and Repair," in When States Fail: Causes and Consequences, ed. Robert I. Rotberg (Princeton, N.J: Princeton University Press, 2004), 1-49.

${ }^{108}$ Peter Andreas, "Symbiosis Between Peace Operations and Illicit Business in Bosnia," International Peacekeeping 16, no. 1 (January 26, 2009): 33-46, doi:10.1080/13533310802485518.
} 
absent and customary authorities were the main providers of public order. ${ }^{109}$ The armed group quickly and forcefully managed to replace customary rule, another form of nonstate public ordering, in the provision of certain public services - security, taxation, funding of schools and hospitals - and the administration of informal economic networks. ${ }^{110}$ While the State's presence in the region remained weak after the end of the conflict, the RDC-ML managed to replace pre-existing coercive actors due to their greater capacity to claim control over the means of violence in the POR. As a consequence, service provision, including security, became increasingly selective since the RDC-ML used coercion to favour certain groups and control others based on ethnic ties.

In Sierra Leone, the civil war disrupted local authority structures. Following the end of the armed conflict in 2002, youth groups increasingly imposed themselves over communities, contributing sometimes to violence but also providing security in spaces where the state police was rarely seen. ${ }^{111}$ According to Bruce Baker, evidence from Sierra Leone suggests that the pluralism of state and non-state security agencies "is almost all that the weakest members [of weak states] know of policing." ${ }^{112}$ The concept of the State's monopoly over the legitimate use of coercive force remained foreign for marginalized groups. Where the State has no capacity or incentive to provide services and

\footnotetext{
${ }^{109}$ Meagher, "The Strength of Weak States?," 1088-89.

${ }^{110}$ Ibid., 1086-87; Stephen Jackson, "Fortunes of War: The Coltan Trade in the Kivus," in Power, Livehood and Conflict: Case Studies in Political Economy Analysis for Humanitarian Action, ed. S. Collinson, Humanitarian Policy Group, Overseas Development Institute (London, 2003), http://www.refworld .org/docid/4a5b32c20.html.

${ }^{111}$ Berg, "Young but Not Alone; Youth Organizations and the Local Politics of Security Provision."

${ }^{112}$ Baker, Multi-Choice Policing in Africa, 154.
} 
produce public order, non-state public ordering sometimes becomes the rule rather than the exception.

\subsection{Pluralist PORs with strong state and non-state actors}

In other pluralist PORs, state-based security agencies play a more important role in the production of public order, but state formal public ordering remains limited. In those situations, state coercive actors may cohabit more or less peacefully with non-state coercive actors. They also sometimes engage in informal public ordering. For example, in Iraq after the American invasion in 2003, state-sponsored militias used their privileged position under the Iraqi Interim Government and their counter-insurgency mandate to eliminate political opponents. Between 2004 and 2006, the Wolfe Brigade, a Shiite special force commando unit under the authority of the Minister of Interior, patrolled alongside the American coalition in Mosul and Baghdad. At night however, the Brigade also engaged in sectarian violence against Sunnis, raiding households, committing gross human rights violations, and perpetrating extrajudicial executions. ${ }^{113}$

In El Salvador, gangs such as the Mara Salvatrucha and the Barrio18 fight to control and expand their turf on which they depend to extract revenue. As a response, the national police rely on repressive crime-fighting strategies such as large-scale anti-gang operations. However, the State fails to ensure a permanent presence in many of the communities controlled by gangs. Due to territorial competition in spaces controlled by one gang or the other, people are forced out of their homes, and access to schools and services as well as freedom of movement are limited by the enforcement of territorial

\footnotetext{
${ }^{113}$ Ches Thurber, "Militias as Sociopolitical Movements: Lessons from Iraq's Armed Shia Groups,” Small Wars \& Insurgencies 25, no. 5-6 (September 3, 2014): 900-923.
} 
boundaries. This localized control enables local gangs to implement protection rackets and extortion networks. ${ }^{114}$ As a result and because they have a clear incentive to do so, gangs act as coercive actors and produce public order, regulating behaviours in spaces they control. On the other hand, circumventing the formal justice system, police agents have formed death squads targeting gang members in retribution for attacks against personnel and police stations, which were a response to large anti-gang operations and other repressive crime-fighting strategies. ${ }^{115}$

In summary, the configuration of pluralist PORs varies across time and space, but they characterize fragile states where central governing authorities have low capacities and lack an effective monopoly over the means of violence. For those reasons, the formal role of state-based security agencies in public ordering is usually limited. Non-state actors and informality typically dominate those PORs, or at least play a significant role in them.

These examples show that pluralist PORs can be dysfunctional and violent. Yet, pluralism and informality are not necessarily a cause of violence. ${ }^{116}$ Existing scholarship, as well as the cases examined here, suggests in fact that it is often competition and tensions between coercive actors over the control of resources that lead to dysfunctional regimes and higher levels of violence, as illustrated by El Salvador, the DRC, and Iraq.

\footnotetext{
${ }^{114}$ José Miguel Cruz, "Global Gangs in El Salvador: Maras and the Politics of Violence” (Global Gangs Workshop, Centre on Conflict, Development and Peacebuilding, Geneva, May 14, 2009).

${ }^{115}$ Arron Daugherty, "MS13 Launches Police Assassination Campaign in El Salvador," Insight Crime, April 9, 2015, http://www.insightcrime.org/news-briefs/ms13-launches-police-assassination-campaign-elsalvador; Arron Daugherty, “Uniformed Men Massacre Alleged Gang Members in El Salvador," Insight Crime, May 11, 2015, http://www.insightcrime.org/news-briefs/uniformed-men-massacre-alleged-gangmembers-el-salvador.

${ }^{116}$ Other authors have argued that pluralism is itself a cause of violence. See, for example, Diane E. Davis, "Non-State Armed Actors, New Imagined Communities, and Shifting Patterns of Sovereignty and Insecurity in the Modern World," Contemporary Security Policy 30, no. 2 (2009): 221-45.
} 
Other pluralist regimes, despite the limited role of the State, actually manage to provide some security and stability, such as in the cases of Sierra Leone and Bosnia. Those conclusions have important consequences for SSR in fragile states and the ability of those programs to reach their objectives, given the pluralist nature of PORs in such states.

\subsection{SSR in pluralist public order regimes and prospects for public order}

SSR is the main strategy currently proposed by the international community to manage security and public order in fragile states. As it is currently framed and implemented, SSR assumes that the lack of effective state authority explains conflict and violence. In the absence of a third party providing order, usually the State, competition and conflict between units are more likely. ${ }^{117}$ Accordingly, SSR is both about expanding and constricting state authority in the POR of fragile states. On the one hand, SSR attempts to establish the State's monopoly over the means of violence to ensure that public agencies provide security and justice to the citizenry. On the other hand, these reforms seek to formalize public ordering based on principles of good governance. To do so, SSR focuses first and foremost on state security institutions, including police services, the armed forces, intelligence bodies, the judiciary system, and prisons.

However, empirical evidence suggests that state-centric SSR is partial at best and tends to be disruptive. In the first section of this chapter, I challenged the assumption that the State is the only source of authority, security, and order in fragile states. While state formal public ordering can arguably be conceived as an ideal, other arrangements can

\footnotetext{
${ }^{117}$ Proponents of the state weakness argument pose that conflict happens when the institutions of the State are unable to contain and manage social forces by imposing order. See, for example, Robert H. Bates, When Things Fell Apart: State Failure in Late-Century Africa, Cambridge Studies in Comparative Politics (New York: Cambridge University Press, 2008); Rotberg, "The Failure and Collapse of Nation-States; Breakdown, Prevention and Repair"; Herbst, States and Power in Africa.
} 
provide a sufficient level of public order to enable the conduct of daily life. Non-state and informal public ordering may not be optimal, but they can sometimes be sufficient. The POR framework helps us better understand how public order is produced in fragile states, and subsequently how SSR affects the production of public order in countries where the State is only one player in a complex constellation of coercive actors.

Besides, in fragile states, imposing and maintaining the State's effective control on public order implies the deployment of sufficient capacity to police the space controlled by the POR, the formalization of the rules and norms guiding public ordering in accordance with good governing principles, and the maintenance over time of state authority through local capacity and infrastructure to manage conflicts and administrate the daily life of communities. Thus, SSR is a complex and costly endeavour. Yet, fragile states are characterized first and foremost by low capacity, which limits the ability of the State to invest in its institutions, at least in the short term. State-building interventions also face resource constraints related to donors' fluctuating political will and short-term imperatives. Hence, even with the material and financial support of international donors, SSR remains a long-term, incremental process that cannot establish a monist POR overnight.

Furthermore, under SSR initiatives, it is assumed that the State's capacity and authority will expand to ultimately provide public order to the whole country. Yet, this process appears to be more challenging than expected where formal public ordering by state actors has historically been limited. In pluralist PORs, SSR does not happen in a vacuum. As described earlier, multiple coercive actors can emerge to produce public order where the state is unwilling or unable to do so. Non-state actors and providers of 
informal governance engage in public ordering because they have an incentive to do so. Indeed, public ordering is a costly endeavour, from the definition of norms and rules to their imposition and enforcement. However, when an actor engage in an activity that generates rent and that such activity benefits from a certain level of public order, the actor is likely to produce public order. Over time, public ordering arrangements are developed to answer the demand for public order, manage potential conflicts, and maximise rent seeking. ${ }^{118}$

In these conditions, as state-centric SSR increases the State's formal capacity to claim additional control on the means of violence and the production of public order, it disrupts the structure of the initial POR without much consideration for that disruption. SSR implies a change in the relative capacity of the different coercive actors to claim some control over the means of violence and the transformation of security management, altering the initial balance of power in the regime. These changes can trigger competition and ultimately provoke conflict between coercive actors.

Conflict is not automatic, however. The reinforcement of state capacity can represent an advantage for other coercive actors who do not need to spend as much resources on public ordering activities. Yet, when reinforced formal state claims threaten the activities and interests of informal state actors and non-state actors, conflict is more likely. For

\footnotetext{
${ }^{118}$ The literature on legal pluralism, informality, and property rights provides interesting insights regarding normative arrangements over the ownership and the use of resources. Here, they inform the management of diverse claims over the control of the means of violence. See, for instance, Lee J. Alston, "The Development of Property Rights on Frontiers: Endowments, Norms, and Politics," The Journal of Economic History 72, no. 3 (September 1, 2012): 741-70; Jean Daudelin, "Frontier Violence: Property Rights, Commons Management Costs and Distributional Conflicts" (Working paper, November 11, 2010); Gary D. Libecap, "Contracting for Mineral Rights," in Contracting for Property Rights (Cambridge ; New York: Cambridge University Press, 1989), 29-50; D. Fitzpatrick, "Evolution and Chaos in Property Right Systems: The Third World Tragedy of Contested Access," Yale LJ 115 (2005): 996.
} 
example, the increased formal presence of the State in a POR can represent a risk and a potential loss for coercive actors who engage in rent-seeking activities in spaces where they also guarantee public order. In the case of larger protection rackets, if the State is able to tax people and replace other coercive actors in the production of public order, those actors may face important losses. How SSR manages the redistribution of resources and power within a POR has consequences for the level of public order and the sustainability of the reform process.

Where the State is determined to expand its authority and faces powerful non-state actors with major incentives to keep a degree of control over public order, state-centric SSR is likely to trigger conflict and increase violence. Violence can take three forms. First, violence is likely to increase between coercive actors as they compete for control over the means of violence inside the POR. Under SSR, the expansion of the State can lead non-state actors to violently hold their ground and push back against state attempts to displace them. The State can also choose to use force to consolidate its authority, using its own capacity or relying on external capacities, such as foreign military and police personnel. Furthermore, violence against the population is also likely to increase. In addition to the collateral violence generated by the conflict between coercive actors, the latter can rely on violent means to reassert their authority and control behaviours within the regime. Finally, with coercive actors competing or fighting one another, unregulated social interactions in the absence of a functional POR are likely to be more violent. Increased violence will reduce the level of public order produced by the regime, at least temporarily. 
Overall, the resulting outbreaks of violence may actually undermine the entire SSR process and its sustainability over time. For instance, conflict and violence due to change in the structure of the POR can divert resources and political will from SSR's original objectives toward stabilization, policing, and law enforcement. Based on those propositions, SSR is unlikely to increase the level of public order if it does not take into account its disruptive impact on the structure of the POR, and its potential consequences on public order and violence.

\subsection{Conclusion}

To summarize, pluralist PORs, whose composition varies greatly, characterize fragile states. State-centric SSR programs are unlikely to improve the level of public order in these settings since they only address part of the existing POR and do not consider their disruptive impact on the structure of the regime. SSR implies the reorganisation of institutional arrangements that govern the use of coercive force and the production of public order. This rearrangement is likely to have distributional implications for coercive actors, and thus create tensions and potentially conflict. These conflicts, in turn, can generate violence, both directly and indirectly.

Once SSR is implemented, the level of public order produced by the resulting POR reflects whether new rules governing the production of public order are effectively defined and enforced. Given the pluralist nature of PORs in fragile states, a higher level of public order can only result from an agreement between coercive actors or significant third-party intervention. Otherwise, the resulting POR will present a sub-optimal equilibrium, producing lower levels of public order than the initial POR. 
In the next section of the dissertation, I look at different pluralist PORs in Haiti and El Salvador, and determine how the implementation of SSR and its long-term consequences on the POR have affected the production of public order in each country. I will especially focus on how SSR has dealt with non-state coercive actors and informal public ordering, and how it has affected the level of public order. The next chapter presents the research design and a detailed discussion of the methodology used. 


\section{Chapter: Methodology}

The objective of this dissertation is to better understand how SSR affects the production of public order in fragile states. In the previous chapter, I introduce three key propositions. First, in fragile states, public order is produced by a wide array of state and non-state actors through more or less formal means. This constellation of coercive actors and public ordering mechanisms is better conceived analytically as a pluralist public order regime. Second, despite recent development in the policy and academic literature on SSR, these reforms tend to remain state-centric, focusing mainly if not only on state formal public ordering. Third, by seeking to increase state capacity in order to expand state authority through the regime and thus formalize public ordering, SSR has disruptive consequences on pluralist PORs. SSR alters how control over the means of violence is distributed between coercive actors, which can potentially create tensions and conflict, resulting in lower levels of public order. Hence, state-centric SSR is unlikely to improve the level of public order in a pluralist POR, and might actually have the opposite effect.

To probe these hypotheses, I conduct an empirical analysis of four cases, located in two countries: Haiti and El Salvador. I assess the impact of specific SSR strategies on public order in each country, based on the assumption that SSR seeks to control armed crime and violence in order to enable development and make people safer. In each case, I look at how the chosen SSR strategy affects the existing POR and the level of public order it produces. Ultimately, this dissertation proposes new tools to better understand how state-building initiatives in the security sector of fragile states affect the production of public order and the level of violence in these societies. 
In this chapter, I first lay out the research design and operationalize the key concepts of this dissertation. Second, I discuss case selection and introduce each case. Third, I address ethical and data challenges based on methodological choices: this dissertation is mainly based on participant observation and interviews conducted during field research.

\subsection{Research design}

The hypotheses proposed here are new and concern a reality that has increasingly attracted the attention of researchers and policy-makers alike. There is a growing interest in the role of non-state actors and informal arrangements in governance, illustrated by the scholarship on the political economy of state building, hybrid political orders, rebel governance, and governance beyond statehood. ${ }^{119}$ Yet, the existing literature proposes few analytical tools to make sense more systematically of how the production of public order and the provision of security are governed in fragile states. Consequently, our understanding of how SSR affects those complex polities where the State is only one coercive actor among others remains fuzzy.

In a theory-building effort, I opt for a plausibility probe to determine whether the hypotheses I propose warrant additional research and more systematic testing. ${ }^{120}$ As such, I do not conduct a structured comparison between cases that is better adapted to a hypothesis-testing research objective. However, I draw descriptive and causal inferences

\footnotetext{
${ }^{119}$ See, for example, Ana Arjona, "Wartime Institutions A Research Agenda," Journal of Conflict Resolution, September 23, 2014, 22002714547904, doi:10.1177/0022002714547904; Berdal and Zaum, Political Economy of Statebuilding; Power after Peace; Meagher, “The Strength of Weak States?”; Zachariah Cherian Mampilly, Rebel Rulers: Insurgent Governance and Civilian Life during War (Ithaca, NY: Cornell University Press, 2011); Boege et al., "On Hybrid Political Orders and Emerging States"; Thomas Risse, Governance Without a State?: Policies and Politics in Areas of Limited Statehood (Columbia University Press, 2011).

${ }^{120}$ Alexander L. George and Andrew Bennett, Case Studies and Theory Development in the Social Sciences (Cambridge: The MIT Press, 2005), 75.
} 
from my case studies, which set the basis for a more systematic research agenda on violence and the production of public order in fragile states.

Each case follows the same structure. First off, I provide an overview of the relevant historical and political background to contextualize each case. The empirical analysis is then divided in three sections. The first section introduces the initial POR and the level of public order it produces. The second section details SSR under the period studied and if so, how it targets the different components of the POR (table 1). Third, I evaluate the impact of the given SSR strategy on the POR and the resulting level of public order produced by the regime. For each variable, I only identify some general indicators as specific indicators, sources, and levels of analysis vary from one case to the other due to limited data availability. I discuss data challenges in fragile states later on in this chapter.

I rely on process tracing to verify whether SSR influences the production of public order in fragile states. I evaluate through which process(es) SSR affects the structure of the POR and the resulting level of public order. Process tracing enables me to open the black box of causation, consider alternative explanations that have been discussed in the literature review, reveal unforeseen causal pathways, and observe possible equifinality. ${ }^{121}$ This method increases the potential for internal validity, while enabling me to falsify my hypotheses in part or in their entirety. ${ }^{122}$

\subsubsection{Initial public order regime}

In each case study, I first map out the existing POR, using the matrix presented below (table 1) and based on data collected through field research as well as secondary sources.

\footnotetext{
${ }^{121}$ Ibid., 22.

${ }^{122}$ John Gerring, Case Study Research: Principles and Practices, 1st ed. (Cambridge ; New York: Cambridge University Press, 2007).
} 
I identify coercive actors who successfully claim some control over the means of violence and have a significant impact on the production of public order in a given space and over a specific period. Those accounts are not necessarily exhaustive, but they include all the actors who have a significant impact on the production of public order during the period studied. In each case, I highlight how these coercive actors exercise their control on public order and manage to influence the daily life of communities. If the rules they enforce are codified, I consider that these actors are involved in formal public ordering. If the rules are not clearly codified, I consider that these actors are engaged in informal public ordering. Some actors may be involved in both formal and informal public ordering, which I highlight in my discussion of the regime. Table 1 presents examples of actors who manage to claim some control over the means of violence in different PORs and might be present in the case studies. Once the POR is mapped out, it is easier to illustrate interactions and points of contention between relevant coercive actors and the level of public order produced by the regime.

\subsubsection{Initial level of public order}

The level of public order produced by the POR represents the extent to which "the laws and rules regulating the relationship of individuals to the community, and the public conduct of members within a community, are maintained and observed and authority is obeyed." ${ }^{123}$ I consider that higher levels of public order, where rules are followed and authority is respected, are associated with lower levels of crime and violence, as well as increased perception of security.

${ }^{123}$ Oxford English Dictionary, "Order, N." 
I evaluate the level of public order initially produced by the POR by looking at different indicators of crime and violence, as well as data reflecting popular perception of security. For that purpose, I use crime and violence statistics gathered by international agencies, national governments, and non-governmental organizations at the national and subnational levels. I also gather information about prosecution and imprisonment trends to evaluate the effectiveness of the criminal justice system, and I consult human rights indicators to check for informal public ordering mechanisms and practices contrary to those promoted by the SSR framework (torture, extrajudicial violence, due process, and so on). Furthermore, I rely on public opinion survey about security and victimization to get a better sense of popular perception of public order. I contrast and compare quantitative data with qualitative assessments of the security situation gathered through interviews, media coverage of crime and violence, and reports from non-governmental organisations (NGOs) and research groups on human rights, development, and public security. These indicators supplement one another and provide a more comprehensive picture of the level of public order produced by the regime than strictly relying on crime and violence statistics, such as homicide rates.

\subsubsection{Security sector reform}

The second component of the empirical analysis looks at what constitutes the SSR strategy during the period studied, and if/how it addresses non-state coercive actors and informal public ordering. Each case presents a specific strategy toward SSR, with more or less consideration for the entire POR. I first look at how SSR addresses state public ordering, formal and informal. I then highlight whether the given SSR strategy takes into consideration the rest of the POR and how it does so. 


\subsubsection{SSR and the State}

\subsection{Professionalization}

SSR aims simultaneously at constricting and expanding state public ordering. First, it constricts state public ordering by formalizing security and justice provision by state institutions. Empirically, this restriction is apparent through the reinforcement of the criminal justice chain, the codification or reform of law and criminal codes, the creation or reinforcement of systems of checks and balances, and the development of police and military doctrines based on the protection of and service provision to the population, all with increased considerations and respect for due process, human rights, and civil liberties. The formalization of state public ordering in accordance with principles of accountability, transparency, and respect for human rights constitutes the normative component of SSR, often referred to as the professionalization of state institutions.

\subsection{Reinforcement}

Second, SSR increases state capacity in order to expand state authority through the POR and ultimately establish a monist regime where the State successfully claims a monopoly on the legitimate use of coercive force. The increased weight of the State in the regime is illustrated through boosted material capabilities, budget increases, and investments in infrastructure and personnel. The range of services effectively offered by the State to its population is also an indicator of increased capacity. Finally, qualitative indicators can also attest of the reinforcement of state security and justice institutions: the amount and quality of training provided to civilian, police, and military personnel, and the development of sound policies and strategies, for instance. 


\subsection{Expansion}

The professionalization and the reinforcement of the State's security sector is likely to improve the capacity of the State to expand its claims over the means of violence and the production of public order inside the POR. State expansion illustrated by the State's effective presence through the national territory, the reach of its different security and justice services, the frequency and intensity of patrols and operations, the ability of the population to contact and interact with state security forces, and the number of arrests and prosecutions by the State's criminal justice system.

\subsubsection{SSR and non-state coercive actors}

As described in the previous chapter, the professionalization, the reinforcement, and the expansion of the state apparatus through a pluralist POR does not occur in a vacuum. By expanding the State's claims over the means of violence and transforming how security is managed in the regime, SSR changes the relative distribution of power between coercive actors inside the POR. How SSR manages this disruption is likely to influence the resulting level of public order produced by the regime.

In each case, I consider whether SSR takes into consideration non-state actors and informal public ordering mechanisms at play in the regime, and how the reforms address their impact on the overall production of public order. SSR programs can choose to ignore, eliminate, or co-opt non-state actors and informal public ordering. We can also imagine cases where a mixed strategy is in action, such as including some non-state coercive actors in the reform process while marginalizing or ignoring others. I identify the strategy at play through interviews with relevant stakeholders, a review of public 
statements and media interviews given by key individuals, and an assessment of relevant policies adopted at the time of the reforms.

\subsubsection{Resulting public order regime and level of public order}

In the third section of the empirical analysis, I evaluate the consequences of SSR on the structure of the POR and the respective claims of the relevant coercive actors. I describe the resulting POR after the implementation of SSR based on the same criteria as for the initial POR (section 4.1.1). I use the matrix presented in table 1 to illustrate SSRinduced changes in the POR.

\subsubsection{Resulting level of public order}

Disruption caused by SSR is likely to reduce the level of public order produced by the regime, at least momentarily. Some SSR strategies may be more disruptive than others on the structure of the POR in which they are implemented, affecting the relative ability of pre-existing coercive actors to successfully claim control over the means of violence. When the State faces strong non-state coercive actors who have a significant incentive to claim control over the means of violence to produce public order, conflict is especially likely. In other cases, non-state actors may welcome the increased weight of the State in the regime if it does not infringe on their other activities, as public ordering is a costly activity for them too.

I evaluate the level of public order produced after the implementation of SSR based on the same indicators as those used to describe the initial level of public order (section 4.1.1.1). I give particular attention to evidence of conflict between coercive actors. For instance, an increase in the number of state-led operations targeting non-state coercive actors or in the occurrence of attacks against state forces suggests tensions and conflict 
between coercive actors. Disruption caused by SSR is also likely to lead to a rise in violence towards the population living under the POR, due to the need for coercive actors to reassert their control. Indicators include indiscriminate and abusive police swaps and controls, increased use of violence by various coercive actors to enforce compliance, harsher punitive measures, and arbitrary use of force and authority.

To summarize, the objective is to provide a clearer picture of how (1) public order is produced in fragile states, and (2) how SSR affects these mechanisms. The research design described here provides analytical tools to approach more systematically the study of hybrid polities and the impact of SSR on them. Variables (public order regimes, SSR, level of public order) are operationalized by looking at a wide range of indicators, both qualitative and quantitative, that are not necessarily the same from one case to the other, but nonetheless offer a rich and detailed understanding of complex phenomena.

\subsection{Case selection}

A plausibility probe consists of a preliminary test to verify the potential of new hypotheses. It usually relies on a single case study that is considered not too difficult for

the theory. ${ }^{124}$ As pointed out by Alexander L. George and Andrew Bennett, however, "it is not intended to lower the standards of evidence and inference and allow for easy tests on most-likely cases." ${ }^{125}$ If the theory proposed in the previous chapter does not fit those cases, the results will strongly question the validity and relevance of the hypotheses proposed here.

\footnotetext{
${ }^{124}$ John S. Odell, "Case Study Methods in International Political Economy," International Studies Perspectives 2, no. 2 (May 1, 2001): 166, doi:10.1111/1528-3577.00047.

${ }^{125}$ George and Bennett, Case Studies and Theory Development in the Social Sciences, 75.
} 
For the purpose of this dissertation and to verify whether there is sufficient ground for a more systematic comparative research project at a later stage, I look at two countries that constitute most-likely cases of SSR failure in pluralist PORs: Haiti and El Salvador. The empirical analysis relies on four cases, two in each country. In this section, I discuss the rationale for selecting Haiti and El Salvador as countries of study and introduce the four cases, which were selected based on the presence of a clear security management strategy under SSR and significant variation in the level of public order over time and following the initial implementation of SSR.

\subsubsection{Most-likely cases: Haiti and El Salvador}

\subsubsection{Pluralist PORS}

Haiti and El Salvador are clear examples of pluralist PORs in which SSR has been implemented, and where, at first sight, those reforms failed to improve the level of public order produce by the regime. Preliminary research has also revealed that non-state actors and informal arrangements have played a key role historically in the production of public order in both countries. In Haiti, political elites have historically relied on militias and other paramilitary organizations to control political opposition and ensure their political survival. ${ }^{126}$ More recently, linkages between local armed groups and political entrepreneurs have had a significant impact on violence in Port-au-Prince. ${ }^{127}$ In parallel, anthropological research suggests that Haitians living in popular neighbourhoods of Portau-Prince perceive the State as being mostly absent from their life; as a result, local organisations and associations play a key role in the administration and the protection of

\footnotetext{
${ }^{126}$ Robert Fatton, Haiti's Predatory Republic: The Unending Transition to Democracy (Boulder, Co: Lynne Rienner Publishers, 2002).

${ }^{127}$ Schuberth, "A Transformation from Political to Criminal Violence?"
} 
these communities. ${ }^{128}$ In El Salvador, the civil war (1980-1992) has provided rich grounds for the study of rebel governance. ${ }^{129}$ The negotiated end of the conflict suggested a return towards a monist POR, dominated by state formal public ordering. However, since the mid-1990s, media coverage and reports on crime and violence have increasingly highlighted how gangs influence the daily life of local communities and are willing to directly confront police and military forces. ${ }^{130}$

\subsubsection{State-centric SSR}

SSR has been a key component of international intervention in each country. In Haiti, reforming security and justice institutions has been at the core of the mandate of all UN peace operations deployed in Haiti since 1994. Still today, professionalizing the Police Nationale Haitienne (Haitian National Police - PNH), facilitating reforms in the justice

\footnotetext{
${ }^{128}$ Chelsey L. Kivland, "Unmaking the State in 'Occupied' Haiti,” PoLAR: Political and Legal Anthropology Review 35, no. 2 (November 1, 2012): 248-70, doi:10.1111/j.1555-2934.2012.01202.x; Chelsey L. Kivland, "A Report on the Recent Changes in Perceptions of Security and Social Services in Bel Air, Haiti,” Viva Rio Evaluation Project (Small Arms Survey, September 2009).

${ }^{129}$ Elisabeth Jean Wood, "The Social Processes of Civil War: The Wartime Transformation of Social Networks," Annual Review of Political Science 11, no. 1 (June 2008): 539-61, doi:10.1146/annurev.polisci.8.082103.104832; Elisabeth Jean Wood, Insurgent Collective Action and Civil War in El Salvador (New York: Cambridge University Press, 2003).

${ }^{130}$ See, for example, David Gagne, "El Salvador Gangs Take Credit for Homicide Drop During Romero's Beatification,” May 28, 2015, http://www.insightcrime.org/news-briefs/el-salvador-gangs-take-credit-forhomicide-drop-during-romero-beatification; Steven Dudley and Elyssa Pachico, "El Salvador's Gang Truce: Positives and Negatives" (Insight Crime, June 2013); Roberto Valencia, "How El Salvador Handed Its Prisons to the Mara Street Gangs," Insight Crime, September 3, 2014, http:/www.insightcrime.org/news-analysis/how-el-salvador-handed-its-prisons-to-the-gangs; Carlos Martinez, "Ilopango Contra Su Sombra," El Faro, March 18, 2013, http://www.salanegra.elfaro.net/es/201303/cronicas/11434/?st-full_text=1; Douglas Farah, "The Transformation of El Salvador's Gangs into Political Actors" (Center for Strategic and International Studies, June 21, 2012); Sonja Wolf, "Street Gangs of El Salvador," in Maras: Gang Violence and Security in Central America, ed. Thomas Bruneau, Lucía Dammert, and Elizabeth Skinner (Austin: University of Texas Press, 2011), 43-69; Dennis Rodgers and Robert Muggah, "Gangs as Non-State Armed Groups: The Central American Case," Contemporary Security Policy 30, no. 2 (2009): 301-17; Geoff Thale and Elsa Falkenburger, "Youth Gangs in Central America. Issues on Human Rights, Effective Policing, and Prevention," WOLA Special Report (Washington, DC: Washington Office on Latin America, November 2006); Ana Arana, "How the Street Gangs Took Central America," Foreign Affairs 84, no. 3 (June 5 , 2005): 98-110.
} 
sector, and promoting the rule of law constitute central elements of the MINUSTAH. In El Salvador, the peace accords signed in 1992 emphasized the need to transform politics and security. The agreement provided a detailed plan to reform the armed forces and create a new civilian police force, setting the foundation for SSR in the country. In contrast to Haiti, international stakeholders only played a peripheral role in the reform of security and justice institutions in El Salvador. Nonetheless, the reforms implemented in the 1990s were based on stability imperatives and human security principles. In both cases, SSR focused mostly on the formal State's security and justice sector. Some initiatives targeted non-state actors, but they were short-lived and mostly embedded in demobilisation, disarmament, and reintegration efforts.

\subsubsection{Problematic security and public order}

Despite the reform of state security institutions, security remains a challenge in both countries. In Haiti, reports after reports, the UN Secretary-General has indicated to the UN Security Council that the security situation remains calm and stable, but fragile. ${ }^{131}$ Periodic episodes of violence have erupted in the country since the deployment of the MINUSTAH in 2004 and despite SSR progress. ${ }^{132}$ In El Salvador, political violence gave

\footnotetext{
${ }^{131}$ Jan Wörlein, “De La Militarisation de L’aide Humanitaire À La Humanitarization de La Sécurité. Le Nexus - Sécurité - Développement et Le Cas de La MINUSTAH En Haïti” (Sécurité, action humanitaire et aide au développement: quels liens?, Université de Montréal, 2015).

${ }^{132}$ See, for example, David Ariosto, "Violence Grips Haiti after Contested Elections," Al Jazeera America, November 12, 2015, http://america.aljazeera.com/articles/2015/11/12/violence-grips-haiti-after-contestedelections.html; Robert Muggah and Athena R Kolbe, "In Haiti, Violence amid the Rubble," The Globe and Mail, March 5, 2012, http://www .theglobeandmail.com/commentary/in-haiti-violence-amid-therubble/article550656/; Joseph Guyler Delva and Tom Brown, "Gangs Return to Haiti Slum after Quake Prison Break," Reuters, January 17, 2010, http:/www.reuters.com/article/2010/01/17/us-quake-haiti-gangssb-idUSTRE60G0CO20100117; Médecins sans frontières, "Violence, Mortality and Access to Health Care in Cité Soleil, Port-Au-Prince, Haiti. Results of an Epidemiological Survey” (Médecins sans frontières, March 2008); J. Christopher Kovats-Bernat, Sleeping Rough in Port-Au-Prince : An Ethnography of Street Children and Violence in Haiti (Gainesville, FL: University Press of Florida, 2006); Amnesty International,
} 
way to crime shortly after the end of the armed conflict. El Salvador has since become one of the most violent countries worldwide. The number of people killed since 1992 now exceeds the casualties of the war $(75,000) .{ }^{133}$ In 2015 , El Salvador reached a national homicide rate of over 100 murders per 100,000 population, translating into more than 6,000 homicides for a population just over six million. ${ }^{134}$

To sum up, Haiti and El Salvador are most-likely cases of failed SSR in pluralist PORs because they present security environments where non-state actors and informality appear to be common; they have both been the theater of extensive SSR programs; and they remain to a different extent volatile and prone to violence and insecurity, despite reforms. They represent rich field sites to verify the plausibility of the theory proposed here. The next section discusses case selection in each country.

\subsubsection{Case studies}

To probe the theoretical propositions presented in the previous chapter, I selected two cases in each country. In Haiti, while a first attempt at SSR was made in the 1990s, I focus on reforms implemented after 2004. In El Salvador, the analysis focuses on the post-war era (1992 to today), with a specific emphasis on later attempts to complete the unfinished reforms implemented in the 1990s. The Haitian cases highlight the almost immediate and short-term impact of SSR programming on public order and security. The

"Haiti: Breaking the Cycle of Violence: A Last Chance for Haiti?" (Amnesty International, June 21, 2004), http://www.refworld .org/docid/42ae98630.html.

${ }^{133}$ IUDOP, "La Situación de La Seguridad Y La Justicia 2009-2014: Entre Expectativas de Cambio, Mano Dura Militar Y Treguas Pandilleras" (Instituto Universitario de Opinión Publica, Universidad Centroamericana "José Simeón Cañas.," 2014), xix.

${ }^{134}$ Edwin Segura, "El Salvador Con Más Homicidios En C. A.,” La Prensa Gráfica, January 3, 2016, http://www.laprensagrafica.com/2016/01/03/el-salvador-con-mas-homicidios-en-c-a. 
Salvadoran cases look at some of the long-term consequences of incomplete SSR on public order and security in fragile states.

In each country, I select a first period where violence increases and another one where violence remains stable or declines, based on available data and narratives. I expect a difference in strategy towards non-state actors and informal mechanisms of public ordering to explain at least to some extent the variation in the level of public order and violence between cases. Through process tracing, I try to control as much as possible for other factors that may explain variation between cases. Furthermore, while I expect the structure of the POR to vary from one case to another based on the presence of specific coercive actors and the prevalence of informality, pluralism remains a constant between cases. Selection on the dependent variable enables me to evaluate whether processes explaining variation in the level of public order correspond to my initial hypotheses, and whether they are necessary or sufficient conditions. ${ }^{135} \mathrm{I}$ am aware however that choosing my cases on the dependent variable implies a selection bias, which can understate or overstate the relationship between the variables observed. ${ }^{136}$ I quickly introduce the four cases below, highlighting the main patterns at play in each period.

\subsubsection{Haiti (2006-2009)}

In early 2004, Haiti's president of four years, Jean-Bertrand Aristide, faced mounting contestation and was forced into exile, leaving the country in a de facto state of anarchy. His departure, combined with the deployment of international troops followed by MINUSTAH, led his supporters to take to the streets of Port-au-Prince to denounce the

${ }^{135}$ George and Bennett, Case Studies and Theory Development in the Social Sciences, 23.

${ }^{136}$ Ibid., 24-25. 
interim government and the international presence. The popular opposition quickly turned into violent unrest, as Aristide's supporters clashed with his opponents. The security situation only improved after the election of René Préval as president in early 2006.

Facing a volatile security environment, president Préval took two important decisions in an effort to stabilize the country, combining orthodox SSR with a mixed strategy to deal with non-state armed groups. First, he authorized the PNH reform plan proposed by MINUSTAH, the cornerstone of the SSR process. Second, in the summer of 2006, he announced that local armed groups should choose to disarm or die: groups could disarm and join local peace-building initiatives, or they would be neutralized by MINUSTAH troops. By 2009, Port-au-Prince's core was stabilized and insecurity had significantly declined.

\subsubsection{Haiti (2010-2015)}

On January 12, 2010, a destructive earthquake hit Haiti, killing over 200,000 Haitians and displacing many more. The catastrophe also severely affected development and stabilization initiatives put in place in previous years, in addition to weakening the country's fragile institutions and deferring the electoral process. Michel Martelly, a former music star with little political experience, was finally elected president in the spring of 2011 .

Early in his mandate, Martelly distanced himself from his predecessor Préval, stating publically that he would not negotiate with criminals. He also made the rule of law one of his top priorities. From 2012 however, SSR became increasingly centered on technical aspects of the reforms, without much consideration for the role of informal public 
ordering and non-state actors in security management and public order. Yet, evidence suggests that local armed groups continued to proliferate under Martelly, and some of them benefited significantly from patronage relations with political and economic elites. As a result, the security situation in Haiti and Port-au-Prince especially remained highly volatile, with significant violent upsurges during electoral periods.

\subsubsection{El Salvador (2003-2005)}

SSR was implemented in El Salvador following the end of the civil war (1980-1992) during which a majority of the victims had died at the hands of the state security forces. After the war, despite significant changes in the security sector and the development of a system of checks and balances, insecurity remained a central concern for most Salvadorans. In the direct aftermath of the war, popular opinion surveys identified economic development as the main concern of Salvadorans. By the end of the 1990s, surveys reveal that the population was mostly concerned with crime and insecurity, despite a constant reduction in crime during the same period.

In 2003, months before to the next presidential elections, president Francisco Flores (1999-2004) singled out street gangs as the most important threat to public security in the country during a public address to the nation. His government adopted a series of repressive measures, known as Mano Dura (literally, "firm hand," or "hard line"), aiming at eliminating gangs who, according to his government, controlled entire communities. Violence rose steadily through 2003 and 2004, reaching records levels and profoundly destabilizing popular neighbourhoods of the main cities. By the end of the 2000s, El Salvador was among the most violent countries in the region and across the world, and gangs continued to exert tight control over communities across the country. 


\subsubsection{El Salvador (2009-2014)}

In 2009, El Salvador elected its first government since the end of the war to be led by the former guerrillas' political party, the FMLN. President Mauricio Funes came to power promising to reduce violence and make Salvadorans safer. However, despite a new public security plan that included the reform of some key security institutions, violence levels continued to break records and the Funes administration adopted some repressive measures in response to popular pressure.

Yet, in March 2012, homicides dropped abruptly and remained at their lowest level nation-wide for almost two years. Shortly after the drop, the online newspaper El Faro revealed that a truce had been brokered between the main gangs of the country. ${ }^{137}$ It became progressively evident that the State had provided incentives to the gangs to halt violence. ${ }^{138}$ In late 2012 and early 2013, the government supported talks between local cliques to establish peace zones in municipalities otherwise known for gang presence and high levels of violence. Despite its significant impact on homicides, the truce was highly unpopular among Salvadorans. Homicides started to increase again in late 2013 when it became clear that none of the candidates to the next presidential election would support the truce process.

To sum up, the plausibility probe proposed in this dissertation relies on four cases studies, based in two countries. Haiti and El Salvador constitute most-likely cases of failed SSR in pluralist PORs, and the four cases listed above were selected on variation

\footnotetext{
${ }^{137}$ Oscar Martínez et al., "Gobierno Negoció Con Pandillas Reducción de Homicidios," El Faro, March 14, 2012, http://www .elfaro.net/es/201203/noticias/7985/.

${ }^{138}$ Juan Carlos Lopez, “Funes Responde Al Fiscal General Que Llamó ‘hipócrita' el Pacto Entre Maras En El Salvador," CNN Español, April 19, 2013, http://cnnespanol.cnn.com/2013/04/19/mauricio-funesresponde-al-fiscal-general-que-llamo-hipocrita-el-pacto-entre-pandillas-en-el-salvador/.
} 
on the dependent variable (level of public order), as well as on the strategy chosen to deal with non-state actors and/or informal public ordering in the POR.

\subsection{Data collection}

To probe my hypotheses, I mainly based the empirical analysis on primary data collected through field research. Secondary sources and quantitative data complement the analysis. This section discusses the data collection strategy and the main challenges I encountered during my research.

\subsubsection{Primary sources}

I collected primary data through 12 months of field research in San Salvador (El Salvador), Port-au-Prince (Haiti), and New York City (United States), between August 2012 and June 2015. I did four research trips to El Salvador (August 2012, ${ }^{139}$ May-July 2013, August-September 2013, and May-June 2015) and two to Haiti (June-August 2014 and November-December 2014). I also did an internship with the Security Sector Reform Unit within the Department for Peace Keeping Operations at the UN Headquarters in New York City (October-December 2013), which gave me the opportunity to observe and learn about policy-making processes and practices regarding SSR inside the organisation.

Fieldwork in El Salvador and Haiti presents a series of challenges and risks that shaped my research. I made some decisions that affected my ability to collect certain data in order to ensure the safety of my participants as well as my own. Furthermore, my identity (race, gender, age, and nationality) also certainly influenced my relation with my interviewees and the kind of information I was able to collect, creating both opportunities

\footnotetext{
${ }^{139}$ No official interview was conducted during this first trip to El Salvador. The Carleton University Research Ethics Board approved the project in March 2013.
} 
and challenges. For example, as a woman, I gained access to some powerful stakeholders more easily than some of my male colleagues. However, my gender limited my ability to work at night in some communities and visit spaces I perceive as unsafe, such as prisons. Hence, I am aware of possible biases on my part and from my interviewees, and it has certainly influenced the data I was able to collect and how I interpret them. I quickly discovered, in sum, that there is no such thing as perfect field research and perfect information.

\subsubsection{Interviews}

I conducted a total of 64 formal interviews, in addition to countless off the record conversations with key stakeholders that are not directly cited in this project, but which certainly informed my research, and enabled me to develop a finer understanding of the local situation and triangulate information. I conducted interviews in person or over the phone, based on the preference of my interviewees and logistical challenges.

I structured interviews around a small number of open-ended questions. Due to the sensitivity of some of the topics covered, I adapted the questions and the depth of the interview in response to the participant's reaction and attitude. I generally started with broad factual questions and made my way towards more sensitive issues. Interviews lasted between 30 minutes and three hours. I met with several participants more than once, and rarely conducted the official interview during our first meeting in order to build mutual trust.

I relied on snowball and purposeful sampling to identify potential participants. Gatekeepers played a key role in putting me in contact with individuals that were harder to reach, such as high-level politicians and gang members. I worked with various 
gatekeepers at the same time to prevent unwanted association to specific groups and to cover different networks. ${ }^{140}$ At the end of each interview, I would ask the participant if he/she knew someone else I should talk to.

\subsubsection{Participant observation}

During field research, participant observation also became a core component of this project. As pointed out by Zachariah Cherian Mampilly in his book on insurgent governance in civil wars, participant observation is both necessary and challenging to pursue research projects involving micro-level analysis. ${ }^{141}$ Working in challenging environments where direct access to potential interviewees was limited at first, participant observation allowed me to witness and understand more finely local dynamics, as well as interactions between people and/or organisations. It also became essential to identify potential participants and build trust with local communities, while it gave me the opportunity to assist and participate to key events that later became crucial to my research and were narrated over and over again by interviewees. In other words, it helped me shape the project in ways that I could not have foreseen prior to witnessing firsthand some dynamics surrounding authority, rules enforcement, and the use of violence.

I engaged into participant observation by spending time in communities sitting down in small canteens, talking with street vendors and small shop owners, visiting NGOs sites, churches, and schools, tagging along during patrols with UN military personnel,

\footnotetext{
${ }^{140}$ For example, it was important to engage with representatives from the MS-13 and the Barrio 18 in Ilopango, the municipality where I conducted an important part of my field research in El Salvador, in order to ensure my own safety. Working with only one gang could have led the other gang to associate me with their adversary and therefore perceive me as a threat.

${ }^{141}$ Mampilly, Rebel Rulers, 20.
} 
attending meetings with local leaders, and going to public demonstrations. I compiled my observations in a field journal, which I use to crosscheck information and remember specific events and how they unfolded.

\subsubsection{Ethical considerations}

Ensuring the safety and security of my participants as well as my own was essential to the project. Doing research in fragile and volatile environments comes with its own set of challenges. It is not possible to eliminate all risks. However, I took some measures to mitigate those risks and ensure as much as possible that I would not cause harm to research participants. First, while I did have some printed consent forms available, I often chose to explain orally the project and what participation entailed in order to prevent any paper trace of the interview, especially in the case of vulnerable individuals, such as community leaders or gang members. Furthermore, for some participants such as gang members, a piece of paper has little weight when it comes to reaching an agreement. Their word weighs more than their signature.

Participants were all offered full anonymity. However, some participants demanded that I use their full name and professional title to identify them. Those participants were usually powerful individuals in positions of authority, and were used to giving this type of interview. Participants were also given the opportunity to go off the record on any issue, and they could decide whether the interview would be recorded or not. When I recorded the interview, I asked the interviewee to consent to participate to the research project on tape. Most interviews were recorded. In other cases, I took hand-written notes

during the conversation and destroyed them after transcribing them in an encrypted electronic file. All data collected were kept on encrypted devices, which were stored in a 
safe place inside and outside field sites. I systematically destroyed any written evidence, and I use a coding system to identify participants. No incident jeopardizing data or the identity of the participants occurred.

Second, I also made sure as much as possible to conduct interviews in safe places, for both my interviewees and myself. Building trust through gatekeepers and/or successive meetings was important and often essential. I did very few "cold call" interviews where I had not previously been in touch with the participant. At the end of the interview, I would give my local phone number to the participant, as well as my email address in case he/she decided to withdraw from the project. Participants were given six months to withdraw from the research project. None of them withdrew. I conducted interviews in Spanish, French, and English, without the support of a translator. Each participant was offered to do the interview in the language of his or her choice.

\subsubsection{Secondary sources}

\subsubsection{Qualitative data}

Secondary sources are also an important part of this project. To complement my own data, I rely on local newspaper articles, evaluation reports from non-governmental organizations, international institutions, and donor countries, policy papers written by practitioners, and studies from other researchers. Those sources help to triangulate information and contrast narratives and points of view. They also offer some alternative explanations for variation in the level of public order and violence.

\subsubsection{Quantitative data}


To evaluate the level of public order, I look at a wide range of indicators that vary from one case to the other based on data availability. It includes but is not limited to the level of violence. Violence is usually measured by looking at homicide rates at the national or subnational level since it is the most accurately reported statistic on violent crime. ${ }^{142}$ Relying only on homicide data to evaluate the level of public order in fragile is problematic, however. Due to limited capacity, lack of transparency, and cronyism, data collection is often limited and of poor quality. Different organizations collect data at the national and the subnational levels, but methods, resources, and expertise vary. As I experienced myself, it is often difficult to counter-check data or even trace back their source. In other words, weak states have weak statistics. Besides, as illustrated by the case of El Salvador, trends in homicides do not necessarily reflect trends in popular perception of security.

Consequently, I look at other indicators to evaluate the level of public order. As described previously, these indicators include imprisonment and prosecution numbers, data on kidnappings, gender-based violence, popular opinion surveys, and migration statistics. In the remaining of this section, I expand on challenges surrounding quantitative data specific to Haiti and El Salvador.

\subsubsection{Haiti}

In Haiti, accessing reliable quantitative data and statistics is extremely challenging. First off, the last national census was conducted in 2003 . There are only two forensic pathologists in the entire country, and the only public morgue of the country relies

\footnotetext{
${ }^{142}$ Mayra Buvinic and Andrew Morrison, “How Is Violence Measured?” (Inter-American Development Bank, July 1, 1999), http://publications.iadb.org/handle/11319/5271.
} 
exclusively on a handwritten registry. ${ }^{143}$ The PNH Development Plan (2012-2016) included the creation of an analytic center for crime, but it has not been put in place yet. Furthermore, when a body is reported to the $\mathrm{PNH}$, the immediate determination of the cause of death is left to a juge de paix, not a forensic expert. The juge de paix, head of the peace tribunal, is mandated to administer local justice. He rules and arbitrates local conflict and minor complaints, and he is responsible to receive complains over petty offences and certain misdemeanours. However, due to the limited capacity of the Haitian justice system, the juge de paix is often also responsible to receive more serious complaints, including criminal ones, and transferring them to the competent judicial authority. In the case of a potential homicide, The PNH cannot determine whether there is ground for investigation, since it falls under the responsibility of the juge de paix. This is problematic considering that reforms in the justice sector remain minimal and the juges de paix are selected on the basis of their political affiliation, have little training, and are known to be corrupt. ${ }^{144}$

When it comes to MINUSTAH, the mission only started to collect, compile, and systematically analyze data on crime and violence after the creation of the Joint Mission Analysis Center (JMAC) in 2007, which makes it useless to evaluate the level of public order in the early years of MINUSTAH (2004-2006). JMAC compiles body count rather than homicides, due to the weakness of the Haitian judicial and health system, which prevents an official determination of the cause of death. ${ }^{145}$ MINUSTAH police and

\footnotetext{
${ }^{143}$ Danio Darius, “Anne Fuller Déplore Le Manque de Progrès En Haiti,” Le Nouvelliste (Port au Prince), December 9, 2014, http://lenouvelliste.com/lenouvelliste/article/139076/Anne-Fuller-deplore-le-manquede-progres-en-Haiti.

${ }^{144}$ Interview with a UN senior official, Rule of Law, MINUSTAH, August 2014.

${ }^{145}$ Interview with a UN senior official, JMAC, MINUSTAH, Port-au-Prince, Haiti, December 2014.
} 
military components also compile their own data, which are shared with the JMAC. However, interviews with UN officials reveal tensions between the different components of MINUSTAH (JMAC, police, and military) when it comes to analyzing crime numbers and trends. ${ }^{146}$ MINUSTAH gather most of its data through situation reports filed daily by personnel on the ground. A JMAC official claimed that they manage to report approximately 85 percent of crime and deaths. ${ }^{147}$ This looks unlikely, however, given that reporting depends on the presence of UN personnel on the ground. Hence, MINUSTAH limited reach (most personnel is located in Port-au-Prince) implies limited data. Indeed, diplomats and NGO workers I interviewed often questioned numbers gathered by MINUSTAH. Nonetheless, there is usually consensus over the accuracy of the trends reported by the mission according to discussions I had with diplomats.

Third, some NGOs collect s for specific neighbourhoods or area. For example, Viva Rio Haiti has an analysis center that has compiled homicides in Bel Air and its surroundings since 2007. Médecins sans Frontières has also collected data on violence in Cité Soleil since $2006 .{ }^{148}$ Finally, academic research by Athena Kolbe on public health and living conditions in Port-au-Prince is helpful to get a better sense of the evolution of violence in the capital and its surroundings. ${ }^{149}$ I use those sources to get a better sense of local dynamics and complement information gathered through interviews.

\footnotetext{
${ }^{146}$ Interview with Canadian UNPol H8, MINUSTAH, Port-au-Prince, Haiti, July 2014.

${ }^{147}$ Interview with a UN senior official, JMAC, MINUSTAH, Port-au-Prince, Haiti, December 2014.

${ }^{148}$ Médecins sans frontières, "Violence, Mortality and Access to Health Care in Cité Soleil, Port-Au-Prince, Haiti. Results of an Epidemiological Survey."

${ }^{149}$ Athena R. Kolbe, "Revisiting Haiti’s Gangs and Organized Violence,” Discussion Paper (Rio de Janeiro: Humanitarian Action in Situations other than War, May 2013); Athena R Kolbe et al., "Mortality, Crime and Access to Basic Needs before and after the Haiti Earthquake: A Random Survey of Port-Au-Prince Households," Medicine, Conflict, and Survival 26, no. 4 (December 2010): 281-97; Athena R Kolbe and Royce A Hutson, "Human Rights Abuse and Other Criminal Violations in Port-Au-Prince, Haiti: A Random Survey of Households," The Lancet 368, no. 9538 (2006): 864-73.
} 
Considering these challenges, I rely on a wide range of sources to get a picture as accurate as possible by comparing and contrasting data. During my time in the field, I was able to question data available and gather more information about how they were collected. As such, I consider that contrasting data from different sources and looking at different indicators of security (homicides when available, body counts, kidnappings) is the best way to get a sense of the level of public order and its variation over time in Haiti.

\subsubsection{El Salvador}

In El Salvador, the problem is not as acute, but the quality of statistics has also been questioned. The United Nations Office on Drugs and Crime (UNODC) still reports 139.9 homicides per 100,000 population for $1995 .{ }^{150}$ Yet, many researchers have challenged those numbers. Summarizing this debate, José Miguel Cruz contends that in the years following the end of the civil war in 1992, "the [homicide] rates reached a minimum of approximately 80 homicides per one hundred thousand population," ${ }^{151}$ but it is still difficult to determine the exact homicide rates for this period.

Since 2005, the quality of data has improved following the creation of a panel (Mesa Técnica Tripartida) composed of the PNC, the Fiscal General de la República (Attorney General's Office - FGR), and the Instituto de Medicina Legal (Institute of Forensic Medecine - IML). The panel was created to address the wide discrepancy in data collected by the three institutions. The variations were attributed to problems of coverage. For example, some homicides would not be reported to the PNC in remote areas, but the

\footnotetext{
${ }^{150}$ UNODC, "Intentional Homicide, Count and Rate per 100,000 Population (1995 - 2011)" (United Nations Office in Drugs and Crime, 2013).

${ }^{151}$ José Miguel Cruz, "Violence, Citizen Insecurity, and Elite Maneuvering in El Salvador," in Public Security and Police Reform in the Americas, ed. John Bailey and Lucía Dammert (Pittsburg: University of Pittsburgh Press, 2006), 152.
} 
IML would still compile these murders. ${ }^{152}$ The panel compares numbers gathered by the different institutions and comes up with the official statistics published every year. Despite these improvements in data collection, political pressure to reduce homicide numbers has been reported. ${ }^{153}$ It is unclear to which extent it has affected the validity of official statistics. Based on data I was able to gather, I rely on numbers reported by the PNC until 2004, and by the panel from 2005.

Surveys by the Instituto Universitario de Opinión Publica (University Institute of Public Opinion - IUDOP) are also useful to identify trends in popular perception of public security from the end of the war up to today. For the 2012-2013 case, I also use reports from the Observatorio metropolitano para la prevención de la violencia, which provide desegregated data on crime and violence from the PNC for all the municipalities of the metropolitan zone of San Salvador.

\subsection{Conclusion}

In conclusion, the methodology developed in this chapter seeks to provide the best tools to probe the hypotheses presented earlier. A qualitative approach focusing on a limited number of empirical cases enables me to dig deeper in the processes at play and identify the mechanisms linking security sector reform and public order. In the remaining of this dissertation, a thorough analysis of each case will lead to case-specific conclusions, hypotheses refinement, and the elaboration or a research agenda to test the

\footnotetext{
${ }^{152}$ Interview with a senior advisor, El Salvador's Ministy of National Defence, San Salvador, May 2015. See also Eduardo Ribeiro, Doriam Borges, and Ignacio Cano, "Calidad de Los Datos de Homicidio En América Latina" (Laboratorio de Analisis de la Violencia - Universidad do Estado do Rio de jANEIRO, 2015), 36.

${ }^{153}$ Ibid., 37.
} 
identified mechanisms more systematically. In other words, the objective of this project is to first go in depth to then enable breath.

This chapter concludes the theoretical and conceptual section of the dissertation. The next section presents the empirical analysis of the impact of SSR on public order in fragile states. It includes four chapters, each presenting a specific case study. A final chapter follows, which synthesizes the results of the plausibility probe, refines the hypotheses proposed, and lays out policy implications as well as the next potential steps of this project. 


\section{Chapter: Haiti (2006-2009) - Stabilisation through SSR,}

\section{Disarmament, and Peace Building}

Haiti is the epitome of a fragile state. In 2004, the International Crisis Group argued that "Haiti, 200 years after independence, meets nearly every definition of a failing state." 154 A 2015 report from the World Bank highlights that "in the absence of the state, non-state actors have stepped in: in health, about 50 percent of health expenditures are provided by NGOs and 80 percent of primary and secondary schools are run by private institutions or NGOs." 155 The situation is similar in the security sector. Through its history, Haiti has lacked the capacities and the incentives to exercise an effective monopoly on the use of coercive force. As a consequence, state and non-state actors have produced public order through intertwined formal and informal arrangements, shaping the structure of the prevailing public order regime.

Managing security and public order in Haiti is a complicated business. Democratization and state-building efforts over the last 30 years have taken place in a complex environment shaped by decades of interactions between state and non-state actors claiming some control over the means of violence. Security sector reform first materialised in Haiti in the mid-1990s, as a core element of the democratization process. Donors conceived the disbandment of the armed forces and the creation of a new independent police force as an essential condition to Haiti's stability and development. SSR, as a way to manage security and establish the State's monopoly on the use of

\footnotetext{
${ }^{154}$ International Crisis Group, “A New Chance for Haiti?,” Latin America/Caribbean Report N¹0, (November 18, 2004), 27.

${ }^{155}$ The World Bank, "Haiti: WBG Report Calls for New Social Contract to Promote Opportunities for All," Text/HTML, World Bank, (September 22, 2015), http://www.worldbank.org/en/news/pressrelease/2015/09/22/haiti-wbg-report-calls-for-new-social-contract-to-promote-opportunities-for-all.
} 
coercive force, has since remained central to both stabilisation and development endeavours in the country.

In the next two chapters, I look at renewed SSR efforts in Haiti under the Mission des Nations Unies pour la Stabilisation en Haïti (MINUSTAH) from 2004 to 2015. I argue that the complexity of the POR faced by MINUSTAH after the departure of JeanBertrand Aristide in 2004 called for a broad and comprehensive approach to SSR. While the priority of MINUSTAH was to strengthen the Police Nationale Haïtienne (PNH), police reform was combined to the disarmament, demobilisation, and reintegration of local armed groups and gangs, and to stabilisation efforts in Port-au-Prince. This comprehensive approach, targeting both state and non-state coercive actors, had a positive impact on the level of public order inside the Haitian POR. My analysis focuses on Port-au-Prince and its surroundings, but I also include observations about the general trends at the national level. While those descriptions are in no way exhaustive, they intend to highlight the core elements characterizing the production of public order and the composition of the Haitian POR from 2004 to 2009.

I first provide an historical overview of the evolution of Haitian politics, its impact on security provision in the country, and the first wave of international interventions in Haiti's security sector. Second, I describe the POR in place after the exile of Aristide in 2004. A period of severe insecurity followed the collapse of state central authorities, during which informal public ordering prevailed. Third, I look at SSR under MINUSTAH and President René Préval, and how it was inserted in a broader strategy to stabilise and pacify Port-au-Prince. Fourth, I describe the resulting POR and how the comprehensive 
strategy adopted by the Haitian government managed to improve significantly public order.

\subsection{Haiti: from a strong dictatorship to a weak democracy}

\subsubsection{The predatory state and public ordering}

After its independence in 1804, the Haitian State lacked incentives to provide security to its entire population. After the collapse of the plantation economy, Haitian elites in urban centers took control of the ports and maintained an economic system where the prosperity of a few relied on the exploitation of the majority. ${ }^{156}$ As a result, Haiti has been more often than not a predatory state where the ruling elites have extracted resources from the population to benefit their supporters and ensure their political survival, in cooperation with the Forces Armées d'Haïti (Armed Forces of Haiti - FAd'H). ${ }^{157}$ Furthermore, informality played a key role in the survival of political elites. For instance, under the rule of François "Papa Doc" and Jean-Claude "Bébé Doc" Duvalier (19571986), corruption was key to remuneration, promotion, and advancement within the armed forces due to the limited resources available to compensate military personnel. ${ }^{158}$ Those arrangements maintained the balance between political elites and the military institution. The Duvalier also relied on a paramilitary organisation, the Tontons macoutes, to tame opposition through terror and balance against the coercive power of the armed forces.

\footnotetext{
${ }^{156}$ Laurent Dubois, Haiti: The Aftershocks of History, 1st ed (New York: Henry Holt and Co, 2012), 6.

${ }^{157}$ Fatton, Haiti's Predatory Republic.

${ }^{158}$ Michel S. Laguerre, The Military and Society in Haiti (Knoxville: University of Tennessee Press, 1993), 155.
} 
Left largely to their own means, a large number of Haitians relied on informal mechanisms of local governance to regulate the daily life of their community. ${ }^{159}$ Beidas, Granderson and Neild quote a 1997 report from the Commission Préparatoire à la Réforme du Droit et de la Justice: "Social groups - knowing only the brutal and predatory manifestations of the State - have developed informal justice practices outside of the official administration to regulate the majority of lives." ${ }^{160}$ Local populations regulated and organized themselves around religious and cultural principles such as voodoo $^{161}$ and the Lakou system. ${ }^{162}$ Popular justice through lynching and déchoukaj, ${ }^{163}$ ultimate manifestations of informal public ordering by non-state actors, has also been prevalent throughout Haiti's history.

In sum, security and public order in Haiti has not historically been the preserve of the State. Governing elites have had little incentive to provide security to the population, and the state security forces were essentially used to perpetuate a system of exploitation and exclusion. Non-state actors filled gaps left vacant by the State and more (Lakou) or less formal (déchoukaj) mechanisms regulated the daily life of communities. Hence, public ordering in Haiti has traditionally been a complex and pluralist enterprise.

\subsubsection{The democratization process}

\footnotetext{
${ }^{159}$ Kivland, "Unmaking the State in 'Occupied' Haiti."

${ }^{160}$ See endnote 9 in Sandra Beidas, Colin Granderson, and Rachel Neild, "Justice and Security Reform after Intervention: Haiti," in Constructing Justice And Security After War, ed. Charles Call (Washington, DC: US Institute of Peace Press, 2007), 72.

${ }^{161}$ For a detailed discussion of the evolution of voodoo in Haiti's politics, see Michel Laguerre, "The Place of Voodoo in the Social Structure of Haiti," Caribbean Quarterly 19, no. 3 (September 1, 1973): 36-50.

${ }^{162}$ According to Merilus, "the Lakou system maintains peace, implements regulations, and promotes a unique mutual form of social responsibility among the rural peasants." Jean-Yves Merilus, "Rural Development: The Economic Potentials of Haiti's 'Lakou' System.," Focus on Geography 58, no. 1 (January 1, 2015): 36, doi:10.1111/foge.12047; see also Dubois, Haiti: The Aftershocks of History, 108. ${ }^{163}$ Déchoukaj is a Creole expression referring to violent and destructive popular unrests during which demonstrators will attack bystanders and destroy infrastructures.
} 
In 1986, the Duvalier dictatorship collapsed and a long torturous democratization process followed. A new constitution was adopted by plebiscite in 1987. The document provided for the end of constitutionally enshrined class division between urban citizens and rural peasants, the recognition of Creole (spoken by the vast majority of Haitians) as an official language alongside French, the creation of a new civilian police force independent from the FAd'H, and the reinforcement of judicial guarantees for the protection of human rights.

The end of the Duvalier regime also created space for the political mobilisation of civil society. Jean-Bertrand Aristide, a catholic priest from the popular neighbourhoods of Port-au-Prince, encouraged the mobilization of the marginalised majority, the moun endeyo ("people from outside" in creole), which had been historically ignored and oppressed by economic and political elites. ${ }^{164}$ Based on ti legliz, a derivative of liberation theology, he formed the Lavalas movement, which would become the Fanmi Lavalas political party, and encouraged the formation of organisations populaires, local political organisations.

The democratic transition however threatened the interests of those who had benefited from the Duvalier dictatorship, including the FAd'H and the economic elites who were strongly opposed to Jean-Bertrand Aristide and the Lavalas movement. After the departure of Jean-Claude Duvalier, the Conseil National de Gouvernement (Government National Council - CNG) was formed to govern Haiti during the transition period. Presided by Lieutenant General Charles Namphy, the CNG was dominated by the

\footnotetext{
${ }^{164}$ Robert Fatton Jr., "Citizenship and Democratization in Haiti," in The Future of Liberal Democracy, ed. Robert Fatton Jr. and R. K. Ramazani (New York: Palgrave Macmillan, 2004), 205; Fatton, Haiti's Predatory Republic.
} 
military. As a result, tensions between the government of transition and the Lavalas movement only increased. The armed forces supressed their adversaries through torture and extrajudicial killings. ${ }^{165}$

Aristide won the general elections of December 1990, receiving more than two thirds of the popular vote. He was overthrown less than a year later by the FAd'H, led by General Raoul Cédras, and was forced to leave the country. Over the next three years, the military dictatorship relied on raw violence to crush the opposition and pursue Lavalas members, through both its formal structure and paramilitary organisations, including Cédras' military attachés, former Macoutes, and the Front for the Advancement and Progress in Haiti, know by its French acronym FRAPH. ${ }^{166} 8,000$ people were submitted to abuses, tortured, or killed, and approximate 300,000 people were internally displaced. ${ }^{167}$

\subsubsection{International intervention and SSR in the 1990s}

Under international pressure, General Cédras and Aristide signed the Governors Island Agreement on July 3, 1993. The agreement established the terms for Aristide's return, granted immunity to the military leaders, and included military assistance from the United States to facilitate the transition. The USS Harlan County arrived in Port-auPrince on October 11, 1993, only a few days after 18 U.S. rangers were killed in Somalia. The ship, with 200 troops onboard, faced violent unrest instigated by paramilitary groups on the docks in Port-au-Prince. The USS Harlan County was ordered to turn back the

\footnotetext{
${ }^{165}$ See Beidas, Granderson, and Neild, "Justice and Security Reform after Intervention: Haiti”; Fatton, Haiti's Predatory Republic; Elizabeth Abbott, Haiti: A Shattered Nation (New York ; London: Overlook Duckworth, 2011); Human Rights Watch, "World Report 1994: Haiti,” 1994, https://www.hrw .org/reports/1994/WR94/Americas-06.htm\#P330_164164.

${ }^{166}$ Fatton, Haiti's Predatory Republic, 93-94; Human Rights Watch, "World Report 1994: Haiti."

${ }^{167}$ Beidas, Granderson, and Neild, "Justice and Security Reform after Intervention: Haiti," 72.
} 
next day. Personnel from the UN and the Organisation of American States (OAS) were expulsed from Haiti shortly after. Boosted by the U.S. withdrawal, the military junta claimed they had managed to scare off the Americans. ${ }^{168}$ The UN Security Council (UNSC) and the U.S. planned a more robust military intervention in the summer of 1994. On July 31, the UNSC adopted resolution 940, which authorized a multinational force to facilitate the departure of the military leadership and the return of Aristide. The U.S.-led Operation Restore Democracy, deployed in September 2004, counted on 21,000 troops and opened the way to the United Nations Mission in Haiti (UNMIH).

Security sector reform in Haiti first materialised through the terms of the Governors Island Agreement and the mandate of the UNMIH. While these documents were drafted prior to the emergence of SSR as a concept in the late 1990s, they both included elements related to the spirit of SSR. Resolution 1940 called for "the professionalization of the Haitian armed forces and the creation of a separate police force," alongside the stabilisation of the country and the organisation of legislative elections. ${ }^{169}$ While the original plan was to limit the role and the prerogatives of the army based on the 1987 constitution, Aristide immediately dissolved the armed forces upon his return into power. Despite the constitutional legitimacy of the armed forces, Aristide mistrusted the military due to years of repression against his supporters.

The Haitian security sector was restructured in three phases. First, the armed forces were disbanded. The International Organisation for Migration, the multinational force, and the U.S. government put in place different initiatives to disarm, demobilise, and reintegrate the armed forces. However, if demobilisation was complete, disarmament and

\footnotetext{
${ }^{168}$ See Fatton, Haiti's Predatory Republic, 88-89; Human Rights Watch, "World Report 1994: Haiti."

${ }^{169}$ UN Security Council, “Resolution 940” (New York: United Nations, July 31, 1994).
} 
reintegration were partial at best. On the one hand, the disarmament initiatives were mostly voluntary and coercive disarmament by international forces was limited. In a 2005 report, Robert Muggah claimed: "virtually every disarmament effort in Haiti has failed." ${ }^{170}$ Furthermore, if the formal institution was disbanded, its informal networks remained in place. ${ }^{171}$ The lack of reinsertion opportunities into the formal economy for former FAd'H members and paramilitaries contributed to the perpetuation of those networks. Since then, many former members of the military have been organizing armed groups that have resurfaced periodically and contributed to the volatility of the security environment. ${ }^{172}$

Second, an Interim Police Force was created to fill the security gap left by the disbandment of the armed forces. The multinational force was looking for a short deployment with a quick exit strategy as soon as a domestic force could ensure basic order and security. By March 1995, six months after their arrival, most foreign troops had left Haiti. There were some important flaws in the constitution of the interim police, which include military personnel who were perceived as recycled Tontons Macoutes. ${ }^{173}$ The force was dissolved in December 1995, only a year after its formation.

Third and most importantly, the core component of the intervention in the Haitian security sector was to create a new civilian, community-oriented police force. The first PNH contingent was trained during the winter of 1995 and deployed in July of the same

\footnotetext{
${ }^{170}$ Robert Muggah, "Securing Haiti’s Transition: Reviewing Human Insecurity and the Prospect for Disarmament, Demobilization, and Reintegraiton," Occasional Paper (Geneva: Small Arms Survey, October 2005), xxv.

${ }^{171}$ E. Mobekk, "International Involvement in Restructuring and Creating Security Forces: The Case of Haiti” 12, no. 3 (September 1, 2001): 100.

${ }^{172}$ See, for example, Mendelson-Forman, "Security Sector Reform in Haiti," 23; Muggah, "Securing Haiti's Transition: Reviewing Human Insecurity and the Prospect for Disarmament, Demobilization, and Reintegraiton," xxvi.

${ }^{173}$ Mobekk, “International Involvement in Restructuring and Creating Security Forces,” 102.
} 
year. The objective was to fully train 5,000 new police agents by the end of 1996, less than two years after the deployment of the multinational force. American, Canadian, and French police trainers were in charge of the formation, but the formation was neither comprehensive nor consistent, as the content of the training would vary based on the expertise of the trainers. For instance, Canadian trainers would emphasize a community policing approach while trainers from the French gendarmerie focused on operational and crowd control tactics. Furthermore, while most recruits were trained in Port-au-Prince, the U.S. trained approximately 2,000 recruits on its own soil, which contributed to training fragmentation and undermined the esprit de corps. There was also very little focus on institution building, oversight mechanisms, and police leadership. The former military officers who composed the commanding structure of the $\mathrm{PNH}$ received little new training, unlike new recruits, creating a cleavage inside the institution and perpetuating a military culture at the leadership level. ${ }^{174}$ As a result of the residual authoritarian culture and in the absence of a functioning judicial system and the proper oversight mechanisms, extrajudicial violence committed by members of the PNH was common. Human Rights Watch reported the killing of 46 Haitians by the PNH between July 1995 and December 1996 alone. ${ }^{175}$ Finally, there was ultimately a severe discrepancy between the number of police officers on the payroll of the PNH $(6,000)$ and those who actually showed up to work $(2,000)$ due to corruption, low moral, and a lack of a functional organisational structure. ${ }^{176}$

\footnotetext{
${ }^{174}$ Interview with the director of Haiti's National Police Academy, Port-au-Prince, August 2014.

${ }^{175}$ Human Rights Watch and Washington Office for Latin America, "Haiti: The Human Rights Record of the Haitian National Police" (Human Rights Watch, January 1997).

${ }^{176}$ Kirk Semple, "Haiti’s Struggle to Restore the Rule of Law" (Haiti Democratic Project, March 30, 2004).
} 
SSR efforts in Haiti in the 1990s were mostly technical and ignored in large part the political nature of the police reform process. ${ }^{177}$ International stakeholders were shortsighted, emphasizing the need to quickly fill the security gap without much reflection on the sustainability of the solution put forth. In the words of Johanna Mendelson-Forman, "the demobilization of the Haitian Army and the creation of a new civilian police force [...] were important steps that could have been successful had it no been for the short time frame allowed for success." ${ }^{\prime 178}$ As a consequence, the disbandment of the armed forces contributed to the perpetuation of informal public ordering and to the continuing involvement of non-state armed groups in security, while the creation of a new civilian police force without a clear doctrine and proper checks and balances set fertile grounds for cronyism, extrajudicial violence, and profound popular mistrust. In other words, SSR in the 1990s clearly failed to establish the State's monopoly on the use of coercive force and played into the proliferation of non-state actors and informal public ordering. Those volatile conditions contributed to the political and security crisis that unfolded after the second election of Aristide in 2000.

\subsubsection{0-2004: Aristide's second term}

The election of Aristide in much controversy in 2000 and the complete withdrawal of the UN shortly after set the beginning of a downward spiral towards insecurity. In 2001, Amnesty International reported that violence had plagued much of the 2000 electoral process. ${ }^{179}$ The police had often failed to intervene to stop violence, and they were

\footnotetext{
${ }^{177}$ Mendelson-Forman, "Security Sector Reform in Haiti"; Timothy Donais, "Back to Square One: The Politics of Police Reform in Haiti," Civil Wars 7, no. 3 (2005): 270-87.

${ }^{178}$ Mendelson-Forman, "Security Sector Reform in Haiti," 15.

${ }^{179}$ Amnesty International, "Report 2001: Haiti,” Report 2001, (June 1, 2001), http://www.refworld .org/docid/3b1de37710.html.
} 
suspected of extrajudicial violence, including beatings and assassination. ${ }^{180}$ Policing also became increasingly selective, cracking down on public demonstration organised by Aristide's opponents, but failing to intervene when supporters of Famni Lavalas organised violent protests, setting up barricades, burning tires and stoning vehicles. Selectivity in policing was due to a lack of independence from the country's political forces. Besides, local elected officials formed their own security forces to combat crime, substitute for the ineffective $\mathrm{PNH}$, or to advance their own political agenda.

As the crisis deepened, informal armed bands composed of ex-members of the FAd'H started harassing Aristide's supporters and members of his government. ${ }^{181}$ For his part, Aristide relied on the PNH and on militias called Chimères to conduct violent actions against his opponents, non-governmental organizations, and the press. In 2003, groups initially close to Famni Lavalas turned against Aristide after he allegedly ordered the assassination of one of their leaders in Gonaïves, Amiot Métayer, who was killed in hazy circumstances ${ }^{182}$ By the time Aristide was forced under international pressures to leave Haiti for a second time in January 2004, state central authorities had virtually collapsed, leaving Haiti's in a state of anarchy.

In February 2004, the UNSC authorized the deployment of a new Multinational Interim Force (MIF) led by the U.S. to stabilise the country. ${ }^{183}$ International stakeholders propped an interim government in mid-march 2004, led by President Boniface Alexandre and Minister Gérald Latortue. The interim government, sponsored by foreign powers and

\footnotetext{
${ }^{180}$ Amnesty International, "Haiti: Human Rights Challenges Facing the New Government" (Amnesty International, April 19, 2001), 21-22, http://www .refworld.org/docid/3c29def0e.html.

${ }^{181}$ Mendelson-Forman, "Security Sector Reform in Haiti."

${ }^{182}$ Beidas, Granderson, and Neild, "Justice and Security Reform after Intervention: Haiti," 75.

${ }^{183}$ UN Security Council, "Resolution 1529” (New York: United Nations, February 29, 2004).
} 
selected by members of the diaspora, had little authority and legitimacy beyond Port-auPrince. ${ }^{184}$ Authorized in April of the same year, MINUSTAH obtained a mandate more robust than any previous UN mission deployed to Haiti. Under chapter VII of the UN Charter, it included three main elements: the stabilization of the security situation throughout the country, the reform of the $\mathrm{PNH}$, and the organization of presidential elections as soon as possible. ${ }^{185}$ In order to do so, MINUSTAH originally counted on 1,622 civilian police and 6,700 military troops. Ten years after the deployment of the MNF, security sector reform in Haiti was back to square one. ${ }^{186}$

\subsection{Port-au-Prince after Aristide: the supremacy of informal public ordering}

Armed actors proliferated following Aristide's exile, in a context of neither war nor peace. Often described by international stakeholders as a period of anarchy with criminal groups roaming through the country, ${ }^{187}$ the dire security situation was in part due to tensions and confrontations between the Famni Lavalas party and anti-Aristide groups. The Lavalas movement claimed to be targeted by a human right abuses campaign involving the UN troops, the PNH, militias, and former FAd'H members. ${ }^{188}$ Regardless of whether these accusations stood on solid ground, they highlight the multiplicity of armed actors and the complexity of the security environment at the time. As a results of these

\footnotetext{
${ }^{184}$ See Robert Fatton, The Roots of Haitian Despotism (Boulder: Lynne Rienner Publishers, 2007), $212-17$. ${ }^{185}$ UN Security Council, "Resolution 1542” (New York: United Nations, April 30, 2004).

${ }^{186}$ Donais, "Back to Square One."

${ }^{187}$ For instance, referring to the Interim Cooperation Report from the World Bank, the UN, the IDB, and the European Commission, Winters affirms: "Haiti has been plagued by local armed groups, so called popular organizations that destabilize the country through their ties to either political authorities or the criminal gangs that smuggle drugs for economic rivals. [...] Even worse are groups of hired thugs, or chimeres, who have no ideological commitment, are willing to do anyone's bidding and switch their allegiance whenever circumstances warrant between the government and its opposition". Cecilia Ann Winters, "Institution Building in Haiti: An Assessment of the Interim Cooperation Framework 20042006," Journal of Human Development 9, no. 2 (July 1, 2008): 293, doi:10.1080/14649880802078827. ${ }^{188}$ Bryan Bender, "Haiti Violence Is Seen as Worsening," Boston Globe, October 23, 2004.
} 
tensions, researchers and NGOs still on the ground reported high levels of violence. ${ }^{189}$ The security situation worsened through 2004, and only significantly improved at the end of 2005, for reasons discussed below. This section describes in more detail the POR (table 2) that characterized Port-au-Prince from 2004 until the election of René Préval in January 2006.

Table 2 Public order regime, Port-au-Prince, 2004-2006

\begin{tabular}{|l|l|l|}
\hline & Informal Public Ordering & Formal Public Ordering \\
\hline \multirow{4}{*}{$\begin{array}{l}\text { Non-state } \\
\text { Actors }\end{array}$} & $\begin{array}{l}\text { Rat-pa-kaka } \\
\text { Organisations polulaires }\end{array}$ & \\
\hline \multirow{3}{*}{ Anti-Lavalas groups } & $\begin{array}{l}\text { Criminal gangs } \\
\text { Popular justice }\end{array}$ & \\
& $\begin{array}{l}\text { Paramilitary groups } \\
\text { Extrajudicial violence and human } \\
\text { rights abuses by the police agents }\end{array}$ & $\begin{array}{l}\text { PNH } \\
\text { MINUSTAH }\end{array}$ \\
\hline
\end{tabular}

\subsubsection{State public ordering}

\subsubsection{Formal public ordering}

The Haitian State virtually collapsed following the exile of Aristide. Less than 10 years after its creation, the PNH only relied on 2,500 policemen and lacked infrastructures, resources, and a command structure. ${ }^{190}$ In a 2006 report, the International Crisis Group noted: “The [PNH] are spread thin, poorly equipped, minimally trained and unable to confront any regional smuggling threat such as drugs, weapons, contraband and

\footnotetext{
${ }^{189}$ Kolbe and Hutson, "Human Rights Abuse and Other Criminal Violations in Port-Au-Prince, Haiti"; Médecins sans frontières, "Violence, Mortality and Access to Health Care in Cité Soleil, Port-Au-Prince, Haiti. Results of an Epidemiological Survey"; Amnesty International, "Haiti: Breaking the Cycle of Violence: A Last Chance for Haiti?"; UN Security Council, "Report of the Secretary-General on the United Nations Stabilization Mission in Haiti (November 2004)" (New York: United Nations, November 18, 2004), http://www.un.org/en/ga/search/view_doc.asp?symbol=S/2004/908.

${ }^{190}$ Isabelle Fortin and François-Pierre Pierre, "Haiti et La Réforme de La Police Nationale d'Haïti" (Ottawa: The North-South Institute, December 2008).
} 
human trafficking coming through the porous ports and borders." ${ }^{191}$ Pushed by the UN and a coalition of interested countries, a Transitional Government of Haiti (TGH) led by Gérard Latortue was put in place to ensure the transition and prepare the next general election. However, the government of transition lacked any form of national legitimacy and was highly contested by Aristide's supporters, feeding into popular unrest.

As a consequence, Haiti was mostly policed by foreign troops. MIF first deployed 3,800 troops from the US, Canada, France, and Chile between February and June 2004. ${ }^{192}$ Delays in the deployment of personnel then limited the ability of MINUSTAH to fulfill its mandate early on. After the departure of the MIF in the summer of 2004, MINUSTAH only counted on 2,127 troops, 240 international police officers (UNPol officers), and one formed police unit (FPU) of 125 personnel. ${ }^{193}$ Its capacity increased progressively through the fall. By December 2004, almost 4,500 UN military troops were deployed across the country, and MINUSTAH relied on 560 UNPol officers, and six FPUs with a combined strength of 418 policemen. ${ }^{194}$ In 2005 , its military component was reinforced and a rapid reaction force was created to improve security in Port-au-Prince. ${ }^{195}$

At first, instead of ensuring a constant presence in unsecure areas, MINUSTAH relied on punctual reactive operations alongside the PNH to target local armed groups. The scale and the intensity of some of MINUSTAH anti-gangs operations in 2005 had severe

\footnotetext{
${ }^{191}$ International Crisis Group, "Haiti: Security and Reintegration of the State," Latin America/Caribbean Briefing (Port-au-Prince/Brussels, October 30, 2006), 1.

${ }^{192}$ See Sharon Wiharta et al., "Case Study: Flood and Tropical Storm Jeanne, Haiti, 2004," in The Effectiveness of Foreign Military Assets in Natural Disaster Response (Stockholm, Sweden: Stockholm International Peace Research Institute, 2008), 73.

${ }^{193}$ UN Security Council, "Interim Report of the Secretary-General on the United Nations Stabilization Mission in Haiti (August 2004)” (New York: United Nations, August 30, 2004), http://www.un.org/en/ga/search/view_doc.asp?symbol=S/2004/698.

${ }^{194}$ UN Security Council, "Report of the Secretary-General on the United Nations Stabilization Mission in Haiti (November 2004)."

${ }^{195}$ UN Security Council, "Resolution 1608,” June 22, 2005.
} 
consequences on the local population, with death tolls of several dozens people. ${ }^{196}$ These operations only reinforced the perception in certain circles that MINUSTAH was an occupation force. ${ }^{197}$

Despite popular perceptions of occupation by MINUSTAH and harsh repression by PNH agents and foreign troops, MINUSTAH and the PNH proved unable to control some of the neighbourhoods of the greater Port-au-Prince. In 2005, the PNH and UNPol officers was forced to withdraw from police stations in some of the worst areas of Portau-Prince, including Cité Soleil, because it was facing intense opposition from local armed groups. ${ }^{198}$ A similar situation occurred in Petit-Goâve where former members of the FAd'H occupied a police station. A military operation was necessary in 2005 to retake the building. ${ }^{199}$

Besides, the judiciary was stretched thin, with only 600 magistrates across the country: "[they] are not only insufficiently trained and poorly educated, but lack the material resources, particularly a sufficiently developed infrastructure, for efficient operation." ${ }^{200}$ Lack of capacity in the judicial sector led to prolonged pre-trial detention in despicable conditions, impunity, and extrajudicial violence. Less than 10 percent of the

\footnotetext{
${ }^{196}$ Matt Halling and Blaine Bookey, "Peacekeeping in Name Alone: Accountability for the United Nations in Haiti Comment," Hastings International and Comparative Law Review 31, no. 1 (2008): 464-65; Guy Hammond, "Saving Port-Au-Prince: United Nations Efforts To Protect Civilians In Haiti In 2006-2007" (Washington, D.C.: The Henry L. Stimson Center, June 2012), 15, http://www.stimson.org/content/savingport-au-prince-united-nations-efforts-protect-civilians-haiti-2006\%E2\%80\%932007.

${ }^{197}$ Yves Engler and Anthony Fenton, Canada in Haiti: Waging War on the Poor Majority (Halifax: Fernwood Publishing, 2005).

${ }^{198}$ Interview with David Beer, 2004-2005 MINUSTAH police commissioner, Ottawa, July 2010.

${ }^{199}$ International Crisis Group, "Spoiling Security in Haiti," Latin America/Caribbean Briefing (Port-auPrince/Brussels: International Crisis Group, May 31, 2005), 8, https:/www .crisisgroup.org/latin-americacaribbean/haiti/spoiling-security-haiti.

${ }^{200}$ Winters, "Institution Building in Haiti," 292.
} 
people arrested by the PNH between 2004 and 2006 were convicted for a crime..$^{201}$ Average pre-trial detention length surpassed 13 months in 2004 and 2005 (402.1 and 423.8 days respectively), while being just shy of a year in 2006 (355 days). ${ }^{202}$

\subsubsection{Informal public ordering}

Due to cronyism and abuses under Aristide, the PNH was perceived as a corrupt institution and distrusted by most Haitians. ${ }^{203}$ During his second mandate, Aristide had encouraged police agents to adopt a zero tolerance strategy towards crime. In a radio interview on June 21, 2001, Aristide gave the example of a car thief and affirmed: "you [policeman] do not need to take him to court to answer to the judge, because the car does not belong to him. It is a criminal who is forcing people to get out of their car so he can steal it, and so then it is a culprit." ${ }^{204}$ Aristide's tolerance for summary execution opened the way to the formation of vigilante groups targeting alleged criminals and political opponents. Corruption ran deep in the weak police force. In 2006, the new director of the PNH, Mario Andrésol, declared publically that 25 percent of the police force was corrupt. ${ }^{205} \mathrm{He}$ ordered the arrest of dozens of PNH officers suspected of being involved in drug trafficking, organized kidnapping rings, and politically motivated killings.

Evidence shows that extrajudicial violence remained common during the transition period. A household survey reveals that more than 20 percent of homicides in Port-au-

\footnotetext{
${ }^{201}$ Athena R. Kolbe and Robert Muggah, "Securing the State: Haiti Before and After the Earthquake," in Small Arms Survey 2011: State of Security, ed. Small Arms Survey, Small Arms Survey (Geneva, 2011), 237.

202 Ibid.

${ }^{203}$ Interview with the director of Haiti's National Police Academy, Port-au-Prince, August 2014.

${ }^{204}$ A full transcript of the interview is available at: BBC Monitoring, "Haiti: Aristide Visits Police, Supports Summary Action And 'zero Tolerance,"' June 21, 2001, http://faculty.webster.edu/corbetre/haitiarchive/msg08197.html.

${ }^{205}$ Lorne Matalon, "Haitian Police Chief Battles Widespread Corruption," NPR.org (National Public Radio, January 10, 2006), http://www.npr.org/templates/story/story.php?storyId=5226454.
} 
Prince between February and December 2005 were attributed to members of the PNH and other government security forces. ${ }^{206}$ According to the same survey, the HNP was responsible for 13.8 percent of sexual assaults and 20.3 percent of physical assaults. Approximately one in five threats of death, physical violence, or sexual violence also originated from a member of the PNH. Based on reports of extrajudicial violence, the UNSC urged the Government of Haiti in its resolution 1608 to put an end to impunity and investigate cased of human rights violations involving PNH members. Yet, MINUSTAH was also involved in informal public ordering, as reports of human rights abuses by foreign troops emerged, including rape and indiscriminate shootings. ${ }^{207}$

\subsubsection{Non-state public ordering}

Beyond the PNH and MINUSTAH, a large number of armed groups, with or without political motives, were active in Haiti between 2004 and 2006: former FAd'H members, ousted PNH officers, pro-Lavalas groups and organisations populaires, bases, Chimères, anti-Lavalas factions, local militias, and criminal gangs. ${ }^{208}$ Political motives varied over time and between groups. However, all of them had the capacity to use violence and coercion, and most often than not, managed to claim localized territorial control: "[armed groups] [...] carved out their own 'fiefdoms', excluding the state from entire neighbourhoods while extracting resources from the population through extortion, use of

\footnotetext{
${ }^{206}$ Kolbe and Hutson, "Human Rights Abuse and Other Criminal Violations in Port-Au-Prince, Haiti," 868.

${ }^{207}$ Halling and Bookey, "Peacekeeping in Name Alone," 464-67.

${ }^{208}$ See, for example, Hammond, "Saving Port-Au-Prince: United Nations Efforts To Protect Civilians In Haiti In 2006-2007"; A. Walter Dorn, "Intelligence-Led Peacekeeping: The United Nations Stabilization Mission in Haiti (MINUSTAH), 2006-07," Intelligence and National Security 24, no. 6 (2009): 805-35; Médecins sans frontières, "Violence, Mortality and Access to Health Care in Cité Soleil, Port-Au-Prince, Haiti. Results of an Epidemiological Survey"; Winters, "Institution Building in Haiti"; Kolbe and Hutson, "Human Rights Abuse and Other Criminal Violations in Port-Au-Prince, Haiti”; Muggah, "Securing Haiti’s Transition: Reviewing Human Insecurity and the Prospect for Disarmament, Demobilization, and Reintegraiton"; UN Security Council, "Report of the Secretary-General on the United Nations Stabilization Mission in Haiti (November 2004).”
} 
choke points on main roads, taxes on businesses and remittances, control of access to water and medical clinics, and kidnappings.." ${ }^{209}$ Some of these groups, linked to local community organizations and more traditional forms of local governance, had more legitimacy with local populations. Nonetheless, the large number of non-state coercive actors and conflicts between them fed insecurity.

Armed bands composed of former members of the armed forces had led the insurrection against Aristide in early 2004, managing to take control of the Gonaïves and Port-Haïtien. In some cases, "in order to enhance their public image, the former military offered assistance in restoring public order and were seen, in some places, cooperating with the $[\mathrm{PNH}]$ and being accepted by the local population and administration."210 They took over abandoned police stations and asserted territorial control in many regions of the country. ${ }^{211}$ Chimères, once targeting Aristide's political opponents, turned into gangs for hire, selling their services to the highest bidder.

External stakeholders often describe organisation populaires as the most worrisome non-state armed actor at the time in Port-au-Prince. ${ }^{212}$ Deriving to some extent from Arisitide's social mobilisation and resistance in the 1990s, they were usually based in communities and sometimes provided services to the population, such as protection and money to cover medical expenses. In 2004, pro-Aristide groups unified under the Rat-paKaka banner and openly contested the government of transition. The protest turned into

\footnotetext{
${ }^{209}$ Hammond, "Saving Port-Au-Prince: United Nations Efforts To Protect Civilians In Haiti In 20062007," 14; Dorn, "Intelligence-Led Peacekeeping," 808 and 812.

${ }^{210}$ UN Security Council, "Report of the Secretary-General on the United Nations Stabilization Mission in Haiti (November 2004)."

${ }^{211}$ Ibid.; International Crisis Group, “A New Chance for Haiti?," 16.

${ }^{212}$ See, for instance, International Crisis Group, "Haiti: Security and Reintegration of the State," 4-5; Hammond, "Saving Port-Au-Prince: United Nations Efforts To Protect Civilians In Haiti In 2006-2007," $19-20$.
} 
an open conflict called Operation Baghdad in late 2004. Local armed groups supporting Aristide and close to the Fanmi Lavalas party fought their opponents in downtown Portau-Prince. According to many sources, Anti-Aristide groups relied heavily on violence to target people associated to Fanmi Lavalas. Based on the survey directed by Athena Kolbe, armed anti-lavalas groups were responsible for 13 percent of homicides and 22 percent of physical assaults in Port-au-Prince. ${ }^{213}$ The death of key leaders of the Rat-paKaka movement early in the conflict led to a rapid fragmentation of the groups. Progressively, many of the groups involved in political opposition turned to criminal and predatory activities. ${ }^{214}$

In response to insecurity, communities formed popular local brigades, acting as vigilantes, to protect their neighbourhood and keep armed violence away. ${ }^{215}$ Popular justice was also frequent, ${ }^{216}$ illustrating a clear lack of trust towards the State and its institutions. Hence, the 2004-2006 period was characterized by the presence of multiple groups who could claim some control over the means of violence at least locally, and therefore affect public order. According to interviews conducted by Guy Hammond with MINUSTAH leadership at the time, most armed actors relied on coercion and fear to collect taxes, recruit new members, and claim local power and prestige. ${ }^{217}$ At the same time, the absence of the State in most of these communities made non-state armed actors "a local recourse for swift justice, although they were also brutal in their dispensation of

\footnotetext{
${ }^{213}$ Kolbe and Hutson, "Human Rights Abuse and Other Criminal Violations in Port-Au-Prince, Haiti."

${ }^{214}$ Interview with a Brazilian researcher, Port-au-Prince, December 2014.

${ }^{215}$ UN DDR Resource Center program on Haiti, cited in Hammond, "Saving Port-Au-Prince: United Nations Efforts To Protect Civilians In Haiti In 2006-2007," 20.

${ }^{216}$ Mendelson-Forman, "Security Sector Reform in Haiti," 24.

${ }^{217}$ Hammond, "Saving Port-Au-Prince: United Nations Efforts To Protect Civilians In Haiti In 2006$2007, " 20$.
} 
justice." ${ }^{218}$ The large number of actors with competing claims in a climate of high uncertainty likely contributed to the general insecurity and the high levels of violence reported by NGOs and other stakeholders at the time. ${ }^{219}$

\subsubsection{Level of public order}

As a result of political conflict and competition for resources between coercive actors, the POR in Haiti from 2004 to 2006 produced a low level of public order. As described by the coordinator of a peace-building program funded by USAID in Cité Soleil: "Not only was state presence nonexistent in Cité Soleil, but also public authorities that had been present were considered illegitimate. The police who had worked there up until 2003 were widely despised for their repressive and abusive policing style and were considered by residents as an occupying force. ${ }^{220}$

Donors and other international stakeholders describe at length the state of insecurity and unlawfulness that prevailed after Aristide's departure. Looting, violent crime against the population, and gunfights between non-state armed groups were reported along with accusations of extrajudicial violence and sexual assaults by PNH and MINUSTAH troops. ${ }^{221}$ According to Kolbe and Hutson, 8,000 murders were perpetrated in the greater Port-au-Prince, and 35,000 women were victims of sexual assaults between February 2004 and December 2005..$^{222}$ Kidnappings also increased through 2005 and 2006, with

\footnotetext{
${ }^{218}$ David C. Becker, "Gangs, Netwar, and the 'Community Counterinsurgency' in Haiti," Prism 2, no. 3 (2011): 141.

${ }^{219}$ Kolbe and Hutson, "Human Rights Abuse and Other Criminal Violations in Port-Au-Prince, Haiti"; Donais, "Back to Square One"; Amnesty International, "Haiti: Breaking the Cycle of Violence: A Last Chance for Haiti?"

${ }^{220}$ Becker, "Gangs, Netwar, and the 'Community Counterinsurgency' in Haiti," 138.

${ }^{221}$ Wiharta et al., "Case Study: Flood and Tropical Storm Jeanne, Haiti, 2004," 73.

${ }^{222}$ Kolbe and Hutson, "Human Rights Abuse and Other Criminal Violations in Port-Au-Prince, Haiti."
} 
162 cases reported between April to December 2005. ${ }^{223}$ In 2006, this number increased to 500 as kidnappings became a relatively easy way for armed groups and criminal actors to collect money through ransom. ${ }^{224}$ The security situation in Port-au-Prince only significantly improved after the general election in February 2006 when René Préval, perceived as a candidate of compromise, was elected as president. Nonetheless, several popular neighbourhoods of the capital remained under the yoke of local gangs, often heavily armed.

\subsection{Security sector reform and stabilisation in Port-au-Prince}

René Préval was elected in early 2006, alongside new parliamentarians. The reestablishment of Parliament solved to some extent the crisis of governance and legitimacy that underlied the country's security predicament. However, the situation remained challenging: "Haiti's five-months-old government must confront the illegal armed gangs, break the international crime/political power at ports and borders and cope with rising drug trafficking and kidnapping." 225 The situation in Port-au-Prince was still chaotic, and few government services continued to be provided to the population. ${ }^{226}$ Improving basic security in Port-au-Prince and across the country was the main objective of MINUSTAH: "security, police and disarmament are considered primary objectives for rebuilding and strengthening the judiciary in Haiti., ${ }^{227}$ The strategy was twofold: on the

\footnotetext{
${ }^{223}$ Data gathered by MINUSTAH, cited in: International Crisis Group, "Haiti: Security and Reintegration of the State," 17.

${ }^{224}$ Data gathered by MINUSTAH, cited in: International Crisis Group, "Reforming Haiti's Security Sector," Latin America/Caribbean Report N²8 (New York: International Crisis Group, September 18, 2008), 30 .

${ }^{225}$ International Crisis Group, "Haiti: Security and Reintegration of the State," 1.

${ }^{226}$ Interview with the head of programs, Viva Rio Haiti, Port-au-Prince, July 2014.

${ }^{227}$ Winters, "Institution Building in Haiti," 293.
} 
one hand, reinforcing state security institutions, particularly the PNH, while on the other hand, neutralizing armed groups to stabilise the security environment.

\subsubsection{Security sector reform: reinforcing the PNH}

Early on, SSR was conceived by external stakeholders, including the UN and the main donors, as an essential condition to the stabilization of Haiti. ${ }^{228}$ In resolution 1702 , the UN Security Council (UNSC) referred to "a comprehensive reform of the police, judiciary and correctional systems, to protect and promote human rights and fundamental freedom, and to end impunity." 229 The objectives of the reform was to improve the ability of the PNH to patrol the national territory, fight gang-related violence, deter crime, and improve security. Reinforcing the PNH became the main component of the SSR process, since it was already targeted by bilateral donors and it was assumed to directly contribute to the stabilization and the security of the country. Still, as early as 2005 , the UN Security Council had also recommended an assessment of the judiciary and correctional systems in the face of widespread impunity and pre-trial detention. ${ }^{230}$ However, there was little appetite from the Haitian government to address these issues. ${ }^{231}$

A false start marked the early elaboration of the PNH Reform Plan. The UN designed a first plan without the participation of the Haitian government, and in isolation of

\footnotetext{
${ }^{228}$ Overt the years, I heard academics and practitioners argue that SSR was never on the agenda in Haiti, where efforts were mostly focused on the PNH. This perspective is likely due to a failure of the UN and MINUSTAH to adopt and maintain over time a comprehensive approach to reforms in the security and justice sectors, as well as to resistance from Haitian officials toward reform targeting the judiciary and the rule of law. Nonetheless, the UN has discussed SSR specifically early on in Haiti. For instance, in February 2007, the UNSC called "on the Haitian Government, in coordination with the international community, to maintain the momentum behind security sector reform, in particular the Haitian National Police." See UN Security Council, "Resolution 1743" (New York: United Nations, February 5, 2007).

${ }^{229}$ UN Security Council, "Resolution 1702” (New York: United Nations, July 15, 2006).

${ }^{230}$ UN Security Council, "Report of the Secretary-General on the United Nations Stabilization Mission in Haiti (May 2005)" (New York: United Nations, May 13, 2005), http://www.un.org/en/ga/search/view_doc.asp?symbol=S/2005/313.

${ }^{231}$ Interview with a UN senior official, Rule of Law, MINUSTAH, Port-au-Prince, August 2014
} 
previous programs that had been put in place by the U.S. and Canada since 2004. In January 2006, Prime Minister Latortue came back furious from a trip to the UN headquarters in New York City. He claimed the Special Representative of the Secretary General (SRSG) for MINUSTAH pressured him into signing the reform plan. ${ }^{232}$ Officers of the PNH and the broader public denounced this clear violation of one of the core principle of SSR: local ownership..$^{233}$

Thereafter, a new plan was designed by the MINUSTAH's police component who sought the active collaboration of the PNH leadership to elaborate a document that would be acceptable for the national authorities while responding to the country's security needs. ${ }^{234}$ The plan included the training and vetting of new police agents to reach a force of 14,000 personnel by 2011 , but that number was susceptible to revisions based on the availability of fiscal and financial resources. The Government of Haiti would cover salary and operation costs, while the international community would finance investment in capacity building and infrastructures. President René Préval officially approved the plan in the summer of 2006.

\subsubsection{DDR and violence reduction: disarm or die}

To address insecurity and instability in Port-au-Prince specifically, Préval adopted a strong public rhetoric towards non-state armed groups. In August 2006, he announced on the radio that gangs faced a choice: they ought to disarm or die. ${ }^{235}$ His government would negotiate with groups who accept to lay down their arms, opening the way to a series of

\footnotetext{
${ }^{232}$ Fortin and Pierre, "Haiti et La Réforme de La Police Nationale d'Haïti," 13.

${ }^{233}$ Ibid.

${ }^{234}$ Ibid.

${ }^{235}$ International Crisis Group, "Haiti: Security and Reintegration of the State," 11; PRESIDENT PREVAL “DESARMEMENT OU LA MORT,” 2006, https://www.youtube.com/watch?v=KM8ksNBHm1A\&feature=youtube_gdata_player.
} 
peace-building initiatives in poor neighbourhoods. In the process, he met with some of the most prominent gang leaders in the presidential palace to convince them to disarm, offering financial inducements. ${ }^{236}$ However, he also stated clearly that armed actors who would not disarm would be eliminated, with the support of MINUSTAH police and military components.

Disarming armed groups was a complex endeavour from the start, since Haiti did not correspond to the traditional post-conflict environment for which DDR was originally designed. ${ }^{237}$ Indeed, there had been no open armed conflict and there was therefore no peace agreement to implement or organised rebel groups to disarm, demobilise, and reintegrate. In this context, DDR slowly evolved toward community violence reduction initiatives. After a first attempt at creating a national body in charge of DDR in 2005, the Préval government put in place the Commission nationale pour le désarmement, le démantèlement et la réinsertion (National Commission for Disarmament, Dismantlement and Reinsertion - CNDDR) in December 2006 to establish a dialogue and implement a peace process with different armed groups in Port-au-Prince. CNDDR was composed of individuals chosen by the government and supported politically and financially by MINUSTAH and other bilateral donors. Individuals associated to Fanmi Lavalas dominated CNDDR. Its president, Alix Fils-Aimé, had been a member of parliament under the Fanmi Lavalas banner between 1996 and 1999. Furthermore, the appointment of Samba Boukman, a grassroots leader from Bel Air and one of the figureheads of the

\footnotetext{
${ }^{236}$ Michael Dziedzic and Robert M. Perito, "Haiti: Confronting the Gangs of Port-Au-Prince," Special Report (Washington, D.C.: United States Institute of Peace (USIP), September 2008), 3.

${ }^{237}$ See Robert Muggah and Keith Krause, "Closing the Gap Between Peace Operations and Post-Conflict Insecurity: Towards a Violence Reduction Agenda,” International Peacekeeping 16, no. 1 (2009): 136-50, doi:10.1080/13533310802485617.
} 
Rat-pa-Kaka movement, was controversial and created concerns over the commission neutrality ${ }^{238}$ Nonetheless, CNDDR worked in collaboration with NGOs to put in place a variety of quick-impact projects in participating communities. For instance, the Brazilian NGO Viva Rio Haiti worked in the greater Bel Air area and the U.S. Haiti Stabilization Initiative focused on Cité Soleil. Inside MINUSTAH, the Community Violence Reduction Unit (CVR) also funded dozens of quick-impact projects in support of CNDDR and with partners on the ground to create employment and control small arms proliferation. ${ }^{239}$ According to the staff of NGOs who worked closely with CNDDR, everybody could participate to these programs, except perhaps former FAd'H members. ${ }^{240}$

These initiatives proved unable to induce all groups to disarm. As a result, in December 2006, Préval authorized MINUSTAH to conduct large military operations targeting violent armed groups in Cité Soleil and other zones such as Bel Air, Delmas 2, and Martissant. Over the following months, the Brazilian brigade in charge of Port-auPrince conducted over 15 large military operations, involving several hundreds troops, airborne support, and sometimes dozens of armoured vehicles. ${ }^{241}$ Military troops would first stabilize the environment. The PNH would then enter the sector and conduct arrests, supported by UNPol officers.

\footnotetext{
${ }^{238}$ International Crisis Group, "Haiti: Security and Reintegration of the State," 12.

${ }^{239}$ UN Security Council, "Report of the Secretary-General on the United Nations Stabilization Mission in Haiti (September 2009)" (New York: United Nations, September 1, 2009), http://www.un.org/en/ga/search/view_doc.asp?symbol=S/2009/439; UN Security Council, "Report of the Secretary-General on the United Nations Stabilization Mission in Haiti (August 2008)" (New York: United Nations, August 27, 2008); UN Security Council, "Report of the Secretary-General Ton the United Nations Stabilization Mission in Haiti (August 2007)” (New York: United Nations, August 22, 2007).

${ }^{240}$ Interview with the head of programs, Viva Rio Haiti, Port-au-Prince, July 2014.

${ }^{241}$ Dorn, "Intelligence-Led Peacekeeping," 818.
} 
In sum, early SSR efforts in Haiti combined reinforcement measures targeting the State's security apparatus and initiatives to address non-state armed actors and their impact on public order in Port-au-Prince. This strategy was not limited to state institutions, in large part due to the key role non-state actors played in the prevailing security environment. This comprehensive approach had a significant impact on the production of public order in Port-au-Prince and resulted in a substantial improvement of public security.

\subsection{Resulting public order regime}

This comprehensive approach to SSR adopted by President Préval and MINUSTAH had important consequences on the Haitian POR. First, it expanded formal public ordering by reinforcing the police force and its capacity to patrol alongside UN police and military troops. The important number of UN troops also strengthened the State's position in the regime. Second, violence reduction efforts reduced the number of disruptive non-state armed groups and progressively formalised some of these actors through CNDDR and local peace-building initiatives. As a result, the level of the public order increased, even though the regime remained fragile and pluralist.

\subsubsection{State public ordering}

\subsubsection{Formal public ordering}

SSR slowly started to reinforce the capacity of state actors and formalize state public ordering through the development of more transparent and democratic procedures, as well as through the vetting of the PNH agents. By December 2009, the PNH had reached a force of 9,000 personnel, a number way under the objective of 14,000 for 2011, but yet larger than at any time since its creation in 1995 . Training at the police school was 
suspended in 2009 because the Haitian government did not have the necessary resources to pay the salary of additional policemen. ${ }^{242}$ Nonetheless, recruitment was apolitical and competitive, based on level of education. ${ }^{243}$ The reform plan also prioritized the reinforcement of the judicial police (Direction centrale de la police judiciaire - DCPJ), which was essential to both police and judicial reforms since it targeted the investigative capacity of the police and would enable an evidence-based judicial process. Progress was slow, however. By June 2008, only 67 judicial police officers were deployed across the entire country. ${ }^{244}$

The development of infrastructure and capabilities also progressed, mostly funded through bilateral assistance. Over a hundred of police stations were built or renovated over the course of three years, mostly in the south of the country and in the west department, where Port-au-Prince is located. ${ }^{245}$ By the end of 2009, the PNH had a national headquarters, as well as 253 police stations and substations (only 39 remained not functional). ${ }^{246} \mathrm{~A}$ new police commissariat was opened in Cité Soleil in the second half of 2008, re-establishing a formal permanent presence of the police in the commune after the ousting of the PNH and its UN support in 2005.

However, the small number of agents available had repercussions on the capacity of the PNH to patrol Haiti's territory. For instance, in Cité Soleil, significant progress in

\footnotetext{
${ }^{242}$ Laura Zanotti, "Cacophonies of Aid, Failed State Building and NGOs in Haiti: Setting the Stage for Disaster, Envisioning the Future," Third World Quarterly 31, no. 5 (2010): 758.

${ }^{243}$ Yves-François Pierre and Isabelle Fortin, "La Réforme de La Police Nationale et La Construction Démocratique En Haïti” Revue canadienne d'études du développement, no. 1 (2011): 25.

${ }^{244}$ Ibid., 71.

${ }^{245}$ UN Security Council, "Report of the Secretary-General on the United Nations Stabilization Mission in Haiti (September 2009)"; UN Security Council, "Report of the Secretary-General on the United Nations Stabilization Mission in Haiti (August 2008)."

${ }^{246}$ International Crisis Group, "Keeping Haiti Safe: Police Reform,” Latin America/Caribbean Briefing (Port-au-Prince/Brussels: International Crisis Group, September 8, 2011), 4.
} 
terms of infrastructure was not met with the necessary human resources. The commune's police station and substations had a capacity of 200 to 250 officers, but they only hosted 25 to $35 \mathrm{PNH}$ officers. At any given time, only 10 policemen were present to patrol and ensure security in a sector where more than 100,000 Haitians live. ${ }^{247}$ Despite investments in infrastructure, the PNH remained unable to actively police the sector or project power beyond the police stations themselves. Consequently, the MINUSTAH's Brazilian battalion in charge of this area continued to conduct most patrols.

Regarding the vetting process, the General Director of the PNH claimed in 2008 that 545 agents had been revoked from their functions following an internal review process, without much information about the nature of the procedure. The joint PNH-MINUSTAH vetting process put in place as part of the reform plan as the official vetting channel did not yield the same results, however. Joint vetting was initially supposed to be completed in 2007, but it was slowed down by difficulties in accessing the public records of PNH agents. ${ }^{248}$ By 2010, 7,500 files had been reviewed, but none of the problematic files had led to the dismissal of police agents by Haitian authorities. ${ }^{249}$ Lack of political will from Haitian authorities explains in part the lack of progress in that domain. ${ }^{250}$

The justice sector did not experience the same improvements as the PNH. Long delays and the absence of due process plagued the criminal justice process. The antique code of criminal procedure did not provide a clear division of responsibility between the

\footnotetext{
${ }^{247}$ Becker, "Gangs, Netwar, and the 'Community Counterinsurgency' in Haiti," 148.

${ }^{248}$ James Cockayne, "Winning Haiti’s Protection Competition: Organized Crime and Peace Operations Past, Present and Future," International Peacekeeping 16, no. 1 (2009): 77-99, doi:http://dx.doi.org.proxy.library .carleton.ca/10.1080/13533310802485476; UN Security Council, "Resolution 1780" (New York: United Nations, October 15, 2007).

${ }^{249}$ Pierre and Fortin, "La Réforme de La Police Nationale et La Construction Démocratique En Haïti," 70.

${ }^{250}$ Ibid.
} 
different components of the judicial system (police, juges de paix, investigative judges, and prosecutors). ${ }^{251}$ Fortin and Pierre point to a bad articulation between the PNH and the justice system, but also highlight how personal conflicts between the leadership of the DCPJ and an investigative judge managed to slow down the reform process. ${ }^{252}$ All in all, progress in the justice sector was minimal. Consequently, the PNH was increasingly working in isolation rather than as one component of the criminal justice chain.

Finally, prison conditions were horrid. Prison population grew significantly between 2006 and 2008, as a result of anti-gang operations and a more effective police. Prison population almost doubled from 4,663 in 2006 (49 prisoners per 100,000 population) to 8,204 inmates in 2008 ( 83 prisoners per 100,000 population). However, penitentiary capacities did not increase at the same rate. In 2008, the National Penitentiary in Port-auPrince housed 3,239 inmates, despite the fact that its capacity was evaluated to only 438 inmates. ${ }^{253}$ The situation was similar in other detention centres across the country. The overwhelming majority of incarcerated individuals were in pre-trial detention, attesting of the incapacity of the Haitian judicial system to process files in a timely manner. In addition, it is important to note that those statistics do not reflect the large number of persons held in police stations in prolonged pre-trial detention without a hearing or charge filed. ${ }^{254}$

\footnotetext{
${ }^{251}$ U.S. Department of Defense, "Country Reports on Human Rights Practices for 2009: Haiti," Report, 2009 Country Reports on Human Rights Practices (Washington, D.C.: Department Of State. The Office of Website Management, Bureau of Public Affairs., March 11, 2010), haitil, http://www.state.gov/j/drl/rls/hrrpt/2009/wha/136116.htm.

${ }^{252}$ Pierre and Fortin, "La Réforme de La Police Nationale et La Construction Démocratique En Haïti," 7172.

${ }^{253}$ UN Security Council, "Report of the Secretary-General on the United Nations Stabilization Mission in Haiti (March 2008)" (New York: United Nations, March 26, 2008), 9.

${ }^{254}$ U.S. Department of Defense, "Country Reports on Human Rights Practices for 2009: Haiti."
} 
In spite of slow progress, the UN Security Council continued to affirm that the PNH remained weak and was unable to ensure public order and stability without the support of MINUSTAH. ${ }^{255}$ Insufficient resources and funding undermined the capacity of the State to project authority and provide security to its population. PNH presence outside Port-auPrince was very limited and in some case non-existent. UN military troops and formed police units would compensate for the lack of state presence. Nonetheless, considering significant improvements in the security situation after 2007, MINUSTAH started to restructure its military and police components in late 2008 to adapt to the changing environment and support more adequately the Haitian State. Military personnel were reduced and the number of UNPol officers increased, illustrating a shift in priority from stabilisation to reform.

\subsubsection{Informal public ordering}

Despite reforms, the limited capacity of the State's security sector to produce public order in a formal manner explains to some extent the persistence of state informal public ordering. A core issue remained extrajudicial violence. According to the U.S. State Department, in its 2009 human rights report on Haiti, "the government or its agents did not commit any known politically motivated killings." However, the report mentions allegations of PNH officers' engaging in "unlawful killings," and using excessive force during apprehensions, resulting sometimes in the death of the suspect. In Haiti police and punishment often go hand-in-hand. In response to the lack of trust in the judiciary system, the PNH was sometimes pressured by the population to fulfill right away a punitive role.

\footnotetext{
${ }^{255}$ UN Security Council, "Report of the Secretary-General on the United Nations Stabilization Mission in Haiti (September 2009)"; UN Security Council, "Report of the Secretary-General on the United Nations Stabilization Mission in Haiti (August 2008)."
} 
Furthermore, while the constitution provides for an independent justice system, political interference from the government's legislative and executive branches was commonplace, reflected by pressure on judges assigned to sensitive cases. ${ }^{256}$

\subsubsection{Non-state public ordering}

In the summer of 2006, some gangs refused the deal proposed by Préval. ${ }^{257}$ As a response, Préval put into motion his "disarm or die" strategy. In Cité Soleil alone, aid agencies with staff on the ground estimated the number of gang members at 300 to $600 .{ }^{258}$ After Préval authorized MINUSTAH to intervene in late 2006, successive operations enabled the arrest of approximately 800 members of armed groups throughout Port-auPrince, often qualified by officials as gang members. ${ }^{259}$ The combination of repression and peace-building initiatives reduced the prevalence of non-state informal public ordering and increased the relative weight of formal public ordering in the regime.

Military operations conducted in December 2006 and the first few months of 2007 in Port-au-Prince's ghettos enabled MINUSTAH and the PNH to take over communities and spaces that were ruled by non-state armed groups who were linked to armed crime, sexual violence, kidnapping, and drug trafficking. ${ }^{260}$ In Resolution 1780 of October 2007,

\footnotetext{
${ }^{256}$ U.S. Department of Defense, "Country Reports on Human Rights Practices for 2009: Haiti."

${ }^{257}$ International Crisis Group, "Haiti: Security and Reintegration of the State," 6.

${ }^{258}$ Becker, "Gangs, Netwar, and the 'Community Counterinsurgency' in Haiti," 143.

${ }^{259}$ Reuben Brigety and Natalie Ondiak, "Haiti’s Changing Tide" (Washington, D.C.: Center for American Progrss, September 1, 2009), 27, https://www.americanprogress.org/issues/security/report/2009/09/01/6650/haitis-changing-tide/.

${ }^{260}$ Interview with the head of programs, Viva Rio Haiti, Port-au-Prince, July 2014. See also Hammond, "Saving Port-Au-Prince: United Nations Efforts To Protect Civilians In Haiti In 2006-2007”; Dziedzic and Perito, "Haiti: Confronting the Gangs of Port-Au-Prince"; Robert M. Perito, "Police in Peace and Stability Operations: Evolving US Policy and Practice," International Peacekeeping 15, no. 1 (2008): 51-66, doi:http://dx.doi.org.proxy.library.carleton.ca/10.1080/13533310701879910.
} 
the UNSC "acknowledge[ed] significant improvements in the security situation in recent months but not[ed] that the security situation remain[ed] fragile."261

Once neighbourhoods were stabilised, the Government of Haiti, MINUSTAH, and a range of international donors implemented various programs in different communities to address the root causes of gangs and armed violence. According to CNDDR president, Alix Fils-Aimé, "people will not return guns voluntarily if we do not offer them lives that have more dignity." ${ }^{262}$ Peace-building programs varied a lot in terms of resources, scope, and duration. The Haiti Stabilization Initiative (HSI) and Tambou Lapè (Drums of Peace) constitute two peace-building initiatives that have attracted a lot of attention because of their unorthodox approach to violence reduction and their significant financial resources.

From 2007, Cité Soleil became the fief of U.S. agencies that funded and implemented HSI. A US\$20 million project, HSI sought to improve security, local government capacity, and economic opportunity. ${ }^{263}$ In contrast to other programs discussed below, the objective of HSI was to marginalise gangs Cité Soleil rather than to treat them as legitimate sources of authority. ${ }^{264}$ To do so, HSI offered funding for small local employment projects. Initial access to funding was dependent on the organisation of a public community meeting where fund and labour allocation would be decided collectively. ${ }^{265}$ A second round of funding rewarded successful projects, while those showing evidence of corruption and extortion would be dropped.

\footnotetext{
${ }^{261}$ UN Security Council, "Resolution 1780."

${ }^{262}$ Daniella Bercovith, "Less Guns, More Peace in Haiti," Comunidade Segura, August 31, 2007, http://www.comunidadesegura.org.br/fr/node/36554?q=en/node/36020.

${ }^{263}$ For a detailed discussion of the HIS and its strategy to alter authority structures in Cité Soleil, see David C. Becker and Robert Grossman-Vermaas, "Metrics for the Haiti Stabilization Initiative," PRISM 2, no. 2 (2011): 145-58.

${ }^{264}$ Becker, "Gangs, Netwar, and the 'Community Counterinsurgency' in Haiti," 145.

${ }^{265}$ Becker and Grossman-Vermaas, "Metrics for the Haiti Stabilization Initiative," 145-48.
} 
If the project created new informal community leaders, it also put the population at risk of being targeted by existing armed actors. Furthermore, evidence suggests that despite the fact that HSI rejected officially any form of engagement with strongmen in Cité Soleil, they negotiated directly with gang leaders who influenced who would benefit from HSI funds. ${ }^{266}$ HSI was a short-term initiative; its funding was not renewed for the 2010 fiscal year, which put an end to most projects by the summer of 2009. Reports from the HSI suggest that if Cité Soleil was stabilized, tensions remained important in the communities. ${ }^{267}$ HSI itself cautioned: "if the [U.S.] Defense Department does not reauthorize HSI for fiscal year 2010, it could make matters worse than they were before."

For its part, Tambou Lapè was implemented in Bel Air, a neighbourhood of Port-auPrince known for its deep historical political roots. Tambou Lapè was led by Viva Rio Haiti, the local branch of a Brazilian non-governmental organization known for its violence reduction work in the favelas of Rio de Janeiro. MINUSTAH originally invited Viva Rio to Haiti in 2006 to develop violence reduction programs. In contrast with HSI, Viva Rio worked in collaboration with CNDDR to co-opt and formalize disruptive armed groups in Bel Air. The objective was to open the dialogue to all interested stakeholders and develop a better understanding of the local dynamics to find common ground in which consensus could be built. ${ }^{268}$ In heavy coordination with CNDDR, the NGO brought

\footnotetext{
${ }^{266}$ Moritz Schuberth revealed that, in 2013, he "interviewed one former HSI staff member who had directly negotiated with gang leaders, a claim backed by another former HSI employee in a subsequent interview. To make matters worse, different sources confirmed that gang members were involved in the selection of beneficiaries for cash-for-work projects, which enabled them to favour their own family members, while other community members had to pay in cash or sex for a place on the list." See Moritz Schuberth, "Growing the Grassroots or Backing Bandits? Dilemmas of Donor Support for Haiti's (UN)Civil Society," Journal of Peacebuilding \& Development 11, no. 1 (January 2, 2016): 3-4, doi:10.1080/15423166.2016.1146565.

${ }^{267}$ Becker, "Gangs, Netwar, and the 'Community Counterinsurgency' in Haiti."

${ }^{268}$ Interview with the head of programs, Viva Rio Haiti, Port-au-Prince, July 2014.
} 
to the table rival gang members who agreed to lay down their arms and conclude peace agreements in exchange for the provision of services to the community. Viva Rio would not negotiate directly with gang leaders, but would rather work through community leaders and local associations. Every month when there was no homicide according to Viva Rio's documentation center, the NGO would organize a raffle for the community. Prizes initially comprised scholarships for the children of the community, but also motorcycles for community leaders later on. As part of its broad approach to peace building, Viva Rio also developed various programs, including waste management, water distribution, and capoeira. ${ }^{269}$ Furthermore, the Canadian government mandated Viva Rio to develop a community policing methodology and to organize activities in order to improve police-community relations in Bel Air. ${ }^{270}$

HSI and Tambou Lapè are two examples among a wide range of initiatives targeting violence reduction and stabilisation in Haiti in the late 2000s. The International Organization for Migration, the United Nations Development Programme (UNDP), CVR, and the World Bank also implemented community-based security initiatives. ${ }^{271}$ As pointed out by Robert Muggah, 2007-2009 was a period of experimentation for many donors and organizations to address problem of instability, crime, and violence. ${ }^{272}$ In some cases, donors and the Government of Haiti alike chose to engage with informal armed groups in ways that formalized their authority inside the public order regime, especially at the local level. In other cases, such as HSI, donors refused to engage

\footnotetext{
${ }^{269}$ Brazilian martial art

${ }^{270}$ Foreign Affairs and International Trade Canada, "Summative Evaluation of START's Global Peace and Security Fund - Haiti" (Ottawa: Foreign Affairs and International Trade Canada, April 2009).

${ }^{271}$ International Crisis Group, "Keeping Haiti Safe: Police Reform," 4.

${ }^{272}$ Robert Muggah, "The Effects of Stabilisation on Humanitarian Action in Haiti," Disasters 34 (2010): S444-63, doi:10.1111/j.1467-7717.2010.01205.x.
} 
formally those actors and chose instead to marginalize and counter-balance them. That choice was not made out of a strategic lecture of the regime and its structure, but was rather based on donors' preferences and sensitivities.

There was a clear lack of coherence and coordination between the different funders and organizations involved, as well as between their strategies on the ground. Furthermore, funding constraints and tensions between CNDDR and some external partners, including the UNDP and CVR, limited the impact of peace-building efforts on the ground. ${ }^{273}$ According to many stakeholders, these initiatives lacked a common vision and were unable to sustain transformative change in the daily life of people living in marginalized communities and neighbourhoods. ${ }^{274}$ Nonetheless, these interventions manage to reduce the prevalence of disruptive non-state informal public ordering in the POR until the 2010 earthquake.

\subsubsection{Resulting level of public order}

Three years after the election of René Préval, the UN Secretary General noted in the September 2009 Report to the UNSC: "the security environment in the country remained generally calm, albeit extremely fragile."275 The level of public order certainly improved between 2004 and 2009, but remained susceptible to disruption. Kidnappings dropped from more than 500 in 2006 to 162 in 2008, according to the International Crisis Group. ${ }^{276}$ The U.S. Department of State presents different numbers, but they follow the

\footnotetext{
${ }^{273}$ International Crisis Group, "Keeping Haiti Safe: Police Reform,” 4; Foreign Affairs and International Trade Canada, "Summative Evaluation of START's Global Peace and Security Fund - Haiti," 64.

${ }^{274}$ Interview with the Deputy Police Commissioner, MINUSTAH, Port-au-Prince, July 2014. See also International Crisis Group, "Keeping Haiti Safe: Police Reform," 4.

${ }^{275}$ UN Security Council, "Report of the Secretary-General on the United Nations Stabilization Mission in Haiti (September 2009)," 5.

${ }^{276}$ International Crisis Group, "Reforming Haiti’s Security Sector."
} 
same trend. ${ }^{277}$ From 30 per month in early 2008, kidnappings dropped to less than 8 per month in the first half of 2009. ${ }^{278}$ Yet, a drastic but brief resurgence in kidnappings in August 2008 illustrates the volatility of the security situation. ${ }^{279}$

Homicides also remained relatively low by regional standards (between 5 and 6 homicides per 100,000 population), with a national homicide rate comparable to the United States for the same period. ${ }^{280}$ According to a series of household surveys conducted in Port-au-Prince and its surroundings, violent crime decreased steadily between 2007 and $2010{ }^{281}$ Qualitative assessments of the security situation over time support these findings. UNPol officers who have been deployed several times to Haiti between 2004 and 2009 described how their role evolved from one deployment to another. For instance, in 2009, it was possible to patrol by foot in Cité Soleil, which would have been unthinkable a couple of years before. ${ }^{282}$

Nonetheless, it is important to note that crime and insecurity remained a serious concern for almost two-thirds of Haitians. ${ }^{283}$ According to the same survey, only approximately 40 percent of the population would turn to the police if they were victim of a crime. In the case of theft, almost 30 percent of respondents considered that there is no point in reporting it. Very few respondents would turn to a non-state armed group if they were victim of a crime (1.2 percent for assault or murder threats and 0.4 percent for

\footnotetext{
${ }^{277}$ U.S. Department of Defense, "Country Reports on Human Rights Practices for 2009: Haiti."

${ }^{278}$ UN Security Council, "Report of the Secretary-General on the United Nations Stabilization Mission in Haiti (September 2009)," 5.

${ }^{279}$ UN Security Council, "Report of the Secretary-General on the United Nations Stabilization Mission in Haiti (August 2008)."

${ }^{280}$ UNODC, "Intentional Homicide Count and Rate per 100,000 Population, by Country/Territory (20002012)" (United Nations Office on Drugs and Crime, 2013).

${ }^{281}$ See Kolbe et al., "Mortality, Crime and Access to Basic Needs before and after the Haiti Earthquake."

${ }^{282}$ Interview with Claude Germain Jr., former MINUSTAH UNPol, Montréal, June 2010.

${ }^{283}$ Kolbe and Muggah, "Securing the State: Haiti Before and After the Earthquake," 240.
} 
theft). 50 percent of participants considered that the police should ideally be in charge of security, followed by MINUSTAH (21 percent), and their local government ( 8 percent). Hence, if the security situation improved overall, public ordering did not become the preserve of the State. Security management remained a plural affair, involving a wide range of actors from the immediate network of an individual (relatives, friends, and neighbours) to local authorities, local gangs and armed bands, MINUSTAH, and the PNH. Nonetheless, remaining local armed groups, facing a growing PNH supported by strong and determinate international troops, joined local peace initiatives or blended with local populations, reducing disruption.

\subsection{Conclusion}

Evidence suggests that the broad approach toward security management adopted between 2004 and 2009 had a positive impact on the level of public order in Haiti. All the conditions were present after 2006 to improve the security situation in the country. ${ }^{284}$ First, the Préval government chose to directly deal with non-state coercive actors who had contributed to insecurity after Aristide's exile in early 2004. Through an open invitation to participate to a dialogue process under CNDDR, Préval provided a way for armed groups to integrate the peace-building process and formalize to some extent their authority. Donors provided resources to back the peace-building process with quickimpact projects that facilitated both the disarmament of armed groups and their formalisation through the creation of new community leaders and local governance mechanisms. Second, MINUSTAH's firepower and resolve to use force if necessary gave Préval the means required to eliminate spoilers and reduced disruption over time. Finally,

\footnotetext{
${ }^{284}$ Interview with the head of programs, Viva Rio Haiti, Port-au-Prince, July 2014.
} 
efforts toward the reinforcement of the State's security sector contributed to increasing the relative weight of the State within the POR.

By no mean did the Haitian State ever recognize openly the pluralist nature of the Haitian POR or the weakness of its own institutions. However, Préval did acknowledge that improving security and public order would require a solution that directly addressed the complex security environment that characterized Haiti from 2004. This case strongly suggests that in a highly dysfunctional and fragile pluralist POR, a broad strategy that takes into consideration the regime as a whole and recognizes the influence of non-sate actors on public ordering can have a positive impact on security and stability. In other words, SSR in Haiti between 2004 and 2009 was not based on the sole assumption that expanding the State's capacity to claim control over the means of violence would solve insecurity and enable development. Instead, a mixed strategy based on the right incentives combined to more technical reforms had a positive impact on the level of public order produced by the POR and the resulting security environment in Haiti. SSR did make Haitians safer, even though the road to long-term stability and development remained hazardous. 


\section{Chapter: Haiti (2010-2015) - State-centric SSR, Covert Clientelism, and Volatility}

2010 constitutes a year of rupture in Haiti's recent history. First and foremost, the earthquake that struck the country on January 12, 2010 disrupted recent progress made in terms of security and development. It shattered already limited state capacities, severely affected MINUSTAH leadership, and destabilised local community structures. Moreover, SSR changed course from 2010 onward. The comprehensive approach to stabilisation and peace building that had dominated Préval's presidency gave way to a narrower and more technical conception of state building in Haiti. Efforts in the security sector became increasingly focused on the reinforcement and the professionalization of the $\mathrm{PNH}$, while the momentum surrounding peace building and broad violence reduction initiatives was progressively lost. As a result, SSR became increasingly state-centric, abandoning formalization efforts targeting non-state coercive actors.

Two main factors explain the redefinition of SSR parameters from 2010. First, the earthquake created new priorities in regards to pressing humanitarian assistance needs. It also accelerated a shift in the priorities of external actors from security to development initiatives. Second, the election of Michel Martelly meant a change in the preferences and priorities of the Haitian government away from the emphasis put on stabilisation and peace building by the previous administration. Consequently, SSR in post-earthquake Haiti presents important limits that prevented a sustainable improvement in the level of public order. The POR remained pluralist, highly volatile, and vulnerable to disruption, as illustrated by sporadic public unrest and sharp fluctuation in levels of violence. 
In this chapter, I focus on the direct aftermath of the earthquake and SSR under Martelly's presidency. I first discuss the devastating consequences of the January 12, 2010 disaster on the structure of Haiti's POR (table 3). I then turn to changes in the SSR strategy following the catastrophe and the election of President Michel Martelly. Third, I present the evolution of the POR from 2011 to 2015, and its consequences for the level of public order in Haiti. I conclude by highlighting how state-centric SSR in Haiti has failed to sustainably improve public order in Haiti, ignoring for the most part the limits of formal public ordering, and the complex network between political elites, state coercive actors, and local armed groups.

\subsection{The 2010 earthquake and its consequences on the POR}

The devastating earthquake killed approximately 220,000 people, injured 300,000 more, and left 2.3 million homeless, more than 20 percent of the country's population. ${ }^{285}$ According to the Government of Haiti, the earthquake caused US\$7.8 billion in damage, a number higher than the country's gross domestic product (GDP) in 2009. ${ }^{286}$ Port-auPrince was severely affected by the disaster, especially in the lower parts of the city were most of the government buildings and poor neighbourhoods are located. Considering the high degree of centralisation of the Haitian State and the fact that more than a third of the country's population lives in the metropolitan zone of Port-au-Prince, the earthquake had devastating consequences on state capacity and the Haitian population.

\footnotetext{
${ }^{285}$ Amnesty International, "Facts and Figures - Haiti: Displaced People Still Leave in Despair Four Years after Devastating Earthquake,” January 9, 2014, http://reliefweb.int/sites/reliefweb.int/files/resources/Displaced\%20people\%20still\%20leave\%20in\%20des pair\%20four\%20years\%20after\%20devastating\%20earthquake.pdf; Government of Haiti, "Haiti Earthquake PDNA: Assessment of Damage, Losses, General and Sectoral Needs" (Governement of Haiti, March 24, 2010), 5, http://www.gafspfund.org/sites/gafspfund.org/files/Documents/Haiti_PDNA.pdf.

${ }^{286}$ Government of Haiti, "Haiti Earthquake PDNA: Assessment of Damage, Losses, General and Sectoral Needs," 6.
} 
Table 3 Public order regime, Port-au-Prince, 2010

\begin{tabular}{|l|l|l|}
\hline & Informal Public Ordering & Formal Public Ordering \\
\hline $\begin{array}{l}\text { Non-state } \\
\text { Actors }\end{array}$ & $\begin{array}{l}\text { Community organizations and } \\
\text { leaders } \\
\text { Gangs } \\
\text { Popular justice and lynching }\end{array}$ & \\
\hline State Actors & & $\begin{array}{l}\text { Police forces } \\
\text { Justice system } \\
\text { MINUSTAH }\end{array}$ \\
\hline
\end{tabular}

\subsubsection{Direct consequences of the earthquake on the POR}

The earthquake altered the POR by weakening state capacity, affecting local structures of governance and authority, and allowing for the return of non-state actors who had been neutralised during stabilisation operations between 2006 and 2009. These changes reduced the level of public order produced by the regime and undermined the overall security situation.

\subsubsection{State public ordering}

First and foremost, considering the high degree of centralisation of the Government of Haiti in Port-au-Prince, the disaster severely weakened the State and reduced its capacity to provide public order. 17 percent of public servants were killed, and 28 out of 29 ministry buildings were destroyed, in addition to the presidential palace, the parliament, and the courts of law in Port-au-Prince. ${ }^{287}$

In the security sector specifically, the earthquake ultimately killed 75 police agents, but early estimates evaluated that 500 police officers were missing or unaccounted for

\footnotetext{
${ }^{287}$ Maureen Taft-Morales, "Haiti Under President Martelly: Current Conditions and Congressional Concerns” (Washington, D.C.: Congress Research Service, December 23, 2015), 3.
} 
immediately after the disaster. ${ }^{288}$ The $\mathrm{PNH}$ headquarters and some key police stations were partially destroyed, and digital documentation regarding detainees and the PNH vetting process was lost. ${ }^{289}$ In the West Department where Port-au-Prince is located, 90 percent of police stations were destroyed and the police operated from tents and with severe material constraints in the following months. ${ }^{290}$ The Government of Haiti evaluated that 80 percent of the security and justice infrastructures were affected by the catastrophe, putting important stress on already limited police, judicial, and prison capacities. ${ }^{291}$ MINUSTAH was also badly affected by the earthquake with the death of 102 of its staff members, including key members of its leadership in the collapse of the hotel where its headquarters were located. As a result, the State's policing capacity retracted. For instance, 90 new police agents who had been deployed to Cité Soleil in late 2009 were removed shortly after the earthquake to respond to immediate needs elsewhere. ${ }^{292}$

\subsubsection{Non-state public ordering}

The earthquake also had severe consequences at the local level throughout the greater Port-au-Prince. First, the disaster created important displacements. In the metropolitan zone of Port-au-Prince alone, 1.3 million Haitians lived in temporary shelters and over

\footnotetext{
${ }^{288}$ Isabelle Fortin, "Security Sector Reform in Haiti One Year after the Earthquake," SSR Issue Papers (Waterloo (On): Centre for International Governance Innovation, March 2011), 5.

${ }^{289}$ Hard copies of the PNH vetting files were found in rubbles in April 2010. Ibid.

${ }^{290} \mathrm{CBC}$ interview with Mario Andersol, general director of the PNH, Port-au-Prince February 2010, cited by Ibid., 6 .

${ }^{291}$ Government of Haiti, "Haiti Earthquake PDNA: Assessment of Damage, Losses, General and Sectoral Needs," 39-40.

${ }^{292}$ Becker, "Gangs, Netwar, and the 'Community Counterinsurgency' in Haiti," 148.
} 
500,000 people left the disaster areas and sought refuge elsewhere in the country. ${ }^{293}$ Consequently, in addition to the important death toll, these population movements transformed the composition of many communities in Port-au-Prince, undermining their social fabric and authority structures. In Cité Soleil for instance, early assessments of the security situation show that the earthquake dismantled neighbourhoods, community governance mechanisms, and safeguards that ensured local security. ${ }^{294}$

Second, the earthquake severely damaged eight prisons, including the National Penitentiary in Port-au-Prince. 5,130 detainees escaped countrywide, 4,215 of which where from the National Penitentiary alone. ${ }^{295}$ These escapees included gang members and other criminals who had been arrested during stabilisation operations between 2006 and $2009 .{ }^{296}$ Some of these inmates returned to their community. ${ }^{297}$ In some places, the population strongly rejected them, even lynching some of those former strongmen. ${ }^{298}$ Elsewhere, escapees regrouped and tried to reclaim control over their former turf, creating local conflicts and rivalries with existing authority figures and/or local gangs who had been empowered by the 2007-2009 peace-building process.

The disruption created by the catastrophe and the security gap that followed enabled some non-state actors to increase their control over communities. It affected security and access to aid, including food and shelter. A survey conducted by INURED suggests that gangs quickly took control over many communities in and around Cité Soleil, and acted

\footnotetext{
${ }^{293}$ Government of Haiti, "Haiti Earthquake PDNA: Assessment of Damage, Losses, General and Sectoral Needs," 5.

${ }^{294}$ INURED, "Voices from the Shanties: A Post-Earthquake Rapid Assessment of Cité Soleil, Port-AuPrince,” March 2010, 11, http://www.inured.org/uploads/2/5/2/6/25266591/voices_from_the_shanties.pdf.

${ }^{295}$ Fortin, "Security Sector Reform in Haiti One Year after the Earthquake," 4.

${ }^{296}$ Delva and Brown, "Gangs Return to Haiti Slum after Quake Prison Break."

${ }^{297}$ International Crisis Group, "Keeping Haiti Safe: Police Reform,” 2.

${ }^{298}$ Fortin, "Security Sector Reform in Haiti One Year after the Earthquake."
} 
as gatekeepers over post-disaster assistance. "Sex for food" became common for young girls in and outside camps as local armed groups controlled access to basic supplies and implemented rackets for the resale of World Food Program tickets prices well over affordability. ${ }^{299}$

\subsubsection{Resulting level of public order}

Assessments of the security situation in the direct aftermath of the earthquake vary. According to UN reports, the anticipated surge in violence and large-scale looting right after the earthquake did not occur. ${ }^{300}$ An early evaluation of Haitians' security needs in February 2010 revealed that violence and security were less an issue after the earthquake than prior to the disaster. Indeed, according to a study by the University of Michigan and Small Arms Survey, 69.2 percent of Haitians surveyed prior to the earthquake considered that security was a serious problem. ${ }^{301}$ In comparison, only 20 percent of respondents identified security as a major concern in early 2010. Nonetheless, this unexpected result could be attributed to the fact that access to food and shelter became such acute problems in the weeks following the earthquake that security considerations became secondary.

However, the consequences of the earthquake on the living conditions of Haitians in Port-au-Prince created tensions between access to food, shelter, and basic security. According to INURED, security (7 percent) was the third most pressing concern in Cité Soleil, well behind food (47 percent) and shelter (29 percent). Nonetheless, the report

${ }^{299}$ INURED, "Voices from the Shanties: A Post-Earthquake Rapid Assessment of Cité Soleil, Port-AuPrince," 9 and 12 .

${ }^{300}$ International Crisis Group, "Keeping Haiti Safe: Police Reform,” 2; UN Security Council, "Report of the Secretary-General on the United Nations Stabilization Mission in Haiti (February 2010)" (New York: United Nations, February 22, 2010), 6.

${ }^{301}$ Athena R Kolbe et al., "Assessing Needs After the Quake: Preliminary Findings from a Randomized Survey of Port-Au-Prince Households” (University of Michigan/Small Arms Survey, April 2010), 3. 
reveals that 54 percent of participants did not feel safe at night, mainly because of the absence of the PNH or MINUSTAH. Furthermore, "where the police presence [was] reported, 40 [percent] of respondents complain[ed] that police forces [were] not very effective in protecting people from violence or criminal elements." ${ }^{302}$

The security situation was especially worrisome in camps and isolated communities where relief activities were limited. In March 2010, the Government of Haiti itself assessed that the earthquake had led to a deterioration of security, particularly for people living in the camps. ${ }^{303}$ When asked who had control over security in camps, 40 percent of respondents chose the answer "there is no security." The second most frequent answer was MINUSTAH with 16 percent. ${ }^{304}$ In isolated communities, violence and rackets surrounding food and shelter increased. ${ }^{305}$ Temporary shelters, food scarcity, and lack of state presence especially affected women. Sexual violence (assault and exploitation) increased sharply in the direct aftermath of the catastrophe, as reported by most stakeholders. ${ }^{306}$ Interviews with UNPol officers who were deployed to Haiti in 2010 and

\footnotetext{
${ }^{302}$ INURED, "Voices from the Shanties: A Post-Earthquake Rapid Assessment of Cité Soleil, Port-AuPrince," 11.

${ }^{303}$ Government of Haiti, "Haiti Earthquake PDNA: Assessment of Damage, Losses, General and Sectoral Needs," 9.

${ }^{304}$ INURED, "Voices from the Shanties: A Post-Earthquake Rapid Assessment of Cité Soleil, Port-AuPrince," 13.

${ }^{305}$ INURED, "Voices from the Shanties: A Post-Earthquake Rapid Assessment of Cité Soleil, Port-AuPrince."

${ }^{306}$ The consequences of the earthquake on women and gender relations have been discussed at length in the media, as well as in the policy and the academic literature. See Lynn Horton, "After the Earthquake: Gender Inequality and Transformation in Post-Disaster Haiti," Gender \& Development 20, no. 2 (July 1, 2012): 295-308, doi:10.1080/13552074.2012.693284; Brooke Stedman, "Security After the Quake? Addressing Violence and Rape in Haiti," Peacebrief (Washington, D.C.: United States Institute of Peace (USIP), January 7, 2011), https://www.usip.org/sites/default/files/PB73-Security_After_the_Quake.pdf; Government of Haiti, "Haiti Earthquake PDNA: Assessment of Damage, Losses, General and Sectoral Needs"; INURED, "Voices from the Shanties: A Post-Earthquake Rapid Assessment of Cité Soleil, PortAu-Prince"; Kolbe et al., "Assessing Needs After the Quake: Preliminary Findings from a Randomized Survey of Port-Au-Prince Households"; Susan Presto, "Sexual Assaults in Haitian Camps Prompt Security Enhancements," Voice of America, March 22, 2010, http://www.voanews.com/a/sexual-assaults-in-haitian-
} 
2011 support these findings. When asked about the security situation after the earthquake, they all described an unstable security environment with rising murders, kidnappings, and sexual violence, especially in the camps. ${ }^{307}$

Hence, while the security situation did not spiralled into generalised unrest and violence, the earthquake destabilised the POR and undermined human security by limiting access to basic goods, altering dynamics between coercive actors and the population inside the POR, and reducing the level of public order. In popular neighbourhoods of Port-au-Prince, the State's presence was limited, if not inexistent. The security vacuum created opportunities for competition between non-state armed actors over scarce resources and predatory behaviours towards the population. All in all, the regime produced a low level of public order, as survival of the fittest became the main organising principle in poor neighbourhoods deeply affected by the disaster, and despite significant efforts by grass-root organisations to respond to the population's needs and provide immediate relief. ${ }^{308}$

\subsection{SSR under President Martelly}

General elections were originally planned for February 2010, but the earthquake forced their deferral. The first round of legislative and presidential elections occurred on November 28,2010 . They were undermined by political tensions, violence, irregularities,

camps-prompt-security-enhancements-88857522/163847.html; UN Security Council, "Report of the Secretary-General on the United Nations Stabilization Mission in Haiti (February 2010)."

${ }^{307}$ Interview with a Canadian police officer H8, UNPol, MINUSTAH, Port-au-Prince, July 2014 ; interview with the chief of the Canadian contingent, UNPol, MINUSTAH, Port-au-Prince, July 2014. Those findings are also backed up by many informal discussions I had over the years with Canadian police officers who were deployed to Haiti after the earthquake.

${ }^{308}$ Fortin, "Security Sector Reform in Haiti One Year after the Earthquake," 5; INURED, "Voices from the Shanties: A Post-Earthquake Rapid Assessment of Cité Soleil, Port-Au-Prince," 8. 
and low voter turnout. ${ }^{309}$ After much controversy surrounding the results of the first presidential round, Michel Martelly won the run-off in March 2011. Only 23 percent of registered voters casted their vote during the second round. ${ }^{310}$

Upon his election, Martelly identified four priorities for his government: rule of law, employment, education, and the environment. ${ }^{311}$ During his inaugural speech, he declared Haiti open for business and adopted a strong stance against corruption. Perhaps more significant for SSR, he distanced himself from the previous administration, stating that he would not negotiate with criminals. ${ }^{312}$ Nonetheless, Martelly himself faced allegations of corruption, bribery, and mismanagement early in his mandate..$^{313}$

\subsubsection{SSR: a professional police in a weak security sector}

The earthquake and political uncertainty during the electoral period halted momentarily most efforts toward SSR. In October 2010, the UNSC called upon the Government of Haiti and its foreign partners to "continue to advance security sector reform, in particular as called for in the Haitian National Police (HNP) Reform Plan adopted by the Government of Haiti." ${ }^{, 314}$ The election of Martelly in 2011 resolved in part the political deadlock, and the gradual improvement of the humanitarian situation allowed for a return to pre-earthquake development objectives. SSR, and especially

\footnotetext{
${ }^{309}$ For a detailed account of the 2010-2011 elections, see Maureen Taft-Morales, "Haiti's National Elections: Issues, Concerns, and Outcome," CRS Report for Congress (Washington, D.C.: Congress Research Service, July 18, 2011).

${ }^{310}$ Institute for Democracy and Electoral Assistance, "Vote Turnout Data for Haiti," October 5, 2011, http://www.idea.int/vt/countryview .cfm?CountryCode=HT.

${ }^{311}$ The four Es in french : État de droit, emploi, éducation et environnement.

${ }^{312}$ Interview with a Canadian diplomat, Port-au-Prince, December 2014; Paul Collier, "Haiti: From Natural Catastrophe to Economic Security. A Report for the Secretary-General of the United Nations," January 2009; Michel Martelly, "Haiti: Now Open to Foreign Investors," The Huffington Post, February 8, 2012, http://www.huffingtonpost.ca/michel-martelly/haiti-invest_b_1260540.html.

${ }^{313}$ Freedom House, "Haiti. Freedom in the Wolrd 2013," 2013, https://freedomhouse.org/report/freedomworld/2013/haiti\#.VOC5bFPF9yR.

${ }^{314}$ UN Security Council, "Resolution 1944” (New York: United Nations, October 14, 2010), 2.
} 
police reform, continued to be perceived as an essential condition for Haiti's social, economic, and political development: "for Haiti to attain its goals of economic recovery, social development and effective democratic governance, public security must be guaranteed." ${ }^{315}$ Hence, police reform remained the cornerstone of SSR in Haiti after 2010. However, the justice sector made little progress.

\subsubsection{The PNH}

2011 marked the end of the 2007-2011 PNH Reform Plan that had initiated police reform. As imperatives for humanitarian assistance progressively faded and the UNPol component reorganized itself, MINUSTAH started to develop the 2012-2016 PNH Development Plan, mostly under the leadership of Jaime Vigil, former commissioner of the Salvadoran National Civilian Police and UN Senior Police Advisor in charge of the PNH development. ${ }^{316}$ Delays in the appointment of a prime minister and members of the Conseil Supérieur de la Police Nationale (High Council of the National Police - CSPN) deferred the adoption of the Development Plan, despite Martelly's announced commitment to the reinforcement of the rule of law and the $\mathrm{PNH}^{317}$ According to the PNH organic law, the CSPN, presided by the prime minister, is charged with "the definition of the national policy and strategies concerning the mission of the national police. ${ }^{318}$ Without a prime minister, the CSPN could not approve and adopt the

\footnotetext{
${ }^{315}$ International Crisis Group, “Keeping Haiti Safe: Police Reform,” 15.

${ }^{316}$ Interview with the deputy police commissioner, MINUSTAH, Port-au-Prince, July 2014.

${ }^{317}$ International Crisis Group, "Keeping Haiti Safe: Police Reform," 8.

${ }^{318}$ Government of Haiti, "Loi Relative À La Police Nationale,” Pub. L. No. Monitor n¹03 (1994), https://www.oas.org/juridico/MLA/fr/hti/fr_hti_mla_gen_police.html.
} 
development plan. The nomination of Laurent Lamothe in May 2012 resolved the impasse, and the plan was finally approved in late August 2012. ${ }^{319}$

The Development Plan emphasized the professionalization of the PNH into a capable and institutionalized police force able to project state authority, provide security, and prevent crime and violence. Most importantly, the plan intended to enable the PNH to ensure alone the country's security and stability after the anticipated withdrawal of MINUSTAH in $2016 .^{320}$ The plan was ambitious. It included seven different components: institutional development, human resources and training, crime and violence prevention, reinforcement of the judicial police, crime and violence prevention, reinforcement of the General Inspectorate Office, strategic planning, reinforcement of operational capacities, and reinforcement of the Direction de l'Administration Pénitencière (Direction of Prison Administration). Each component included several actions, ranging from equipping the General Inspectorate Office, renovating existing installations, and increasing the PNH manpower, to the creation of a PNH air unit, an office for the analysis of statistics and crime, and the elaboration of a national community policing strategy. The plan comprised 70 actions, most of which had seen some progress by the end of $2013 .^{321}$ In the fall of 2015, 26 actions were still in the preliminary phase, 38 were considered at an advanced

\footnotetext{
${ }^{319}$ Conseil Supérieur de la Police Nationale, "Bilan de La Mise En Oeuvre Du Plan De Développement de La Police Nationale d'Haïti 2012-2016 (Sur La Période de Septembre 2012 À Juin 2013)" (Port-au-Prince, August 19, 2013), http://www.slideshare.net/laurentlamothe/plan-de-dveloppement-de-la-police-nationaledhati-20122016.

${ }^{320}$ Interview with the deputy police commissioner, MINUSTAH, Port-au-Prince, July 2014.

${ }^{321}$ A copy of the document is available with the author and was acquired during field research in July 2014. MINUSTAH, "État d'Avance de La Mise En Oeuvre Du Plan de Développement de La PNH 2012-2016 (Septembre 2012-Décembre 2013)," N.D.
} 
stage, and six were completed. ${ }^{322}$ Interestingly enough, some actions that were considered well advanced in December 2013 were marked as having accomplished only preliminary progress in 2015, suggesting that the reform of the PNH is far from a linear process. Training at the national school resumed in 2011. The Development Plan fixed the objective at 15,000 police agents trained by 2016 , meaning that at least 6,000 new agents would be recruited between 2013 and 2016 .

Progress accomplished by the PNH was not mirrored in the justice sector. Despite available funding and externally led efforts, there has been very little appetite by political elites to support a true transformation of the State's justice system. The criminal code was out-dated, severe allegations of corruption targeted all levels of the judiciary, and political interference and cronyism were common. Consequently, justice remained the privilege of a few, and the criminal justice process was incredibly slow and mostly ineffective.

Finally, during the electoral campaign, Martelly promised that he would reconstitute a national military force as a way to reassert Haiti's sovereignty and enhance national pride. ${ }^{323}$ A capable civil engineering battalion could also improve the Government of Haiti's ability to respond to natural disasters. However, in a fiscal context where resources were already very limited, an additional security institution appeared misguided

\footnotetext{
${ }^{322}$ République d'Haïti, "5ème Rapport de Mise En Oeuvre Du Plan de Développement de La PNH 20122016" (Port-au-Prince, September 2015), 9, http://www.slideshare.net/jaimevigil108/5eme-rapport-plan-dedeveloppement-pnh-2012-2016-final.

${ }^{323}$ For a discussion about the reestablishment of the Haitian army, see Taft-Morales, "Haiti Under President Martelly: Current Conditions and Congressional Concerns," 39-41; International Crisis Group, "Keeping Haiti Safe: Police Reform," 11-12; Robert Maguire and Courtney McCreesh, "The Challenge of Keeping Haitians Safe," Peacebrief (Washington, D.C.: United States Institute of Peace (USIP), June 13, 2011); Taft-Morales, "Haiti’s National Elections: Issues, Concerns, and Outcome," 15.
} 
to many external experts and Haitian actors ${ }^{324}$ Creating a new military force would divert the resources and the attention of Haiti's government from its established priority in the security sector: the PNH. Moreover, considering the tormented history of the FAd'H and the role its former members played in the destabilization of the country in the early 2000s, there was no national consensus on the need and the potential role of a reinstituted military force. Nonetheless, the Martelly administration created in 2014 a civil defence force, engaged primarily in engineering projects supporting the development of infrastructures, such as roads and bridges. ${ }^{325}$ In 2013 and 2014, Brazil provided civil engineering training to 69 Haitians officers and technicians. ${ }^{326}$

\subsubsection{Dealing with non-state actors: marginalization of peace-building initiatives}

The comprehensive SSR strategy put in place under the Préval administration was mostly abandoned after the earthquake. Emergency relief and humanitarian assistance, in addition to support for the organisation of presidential elections, took precedent over the necessity to ensure the continuity of previous stabilisation initiatives, especially regarding local peace building and community violence reduction. As a result, many programs targeting non-state armed actors and informal public ordering came to an end in 2010 and 2011.

\footnotetext{
${ }^{324}$ International Crisis Group, "Keeping Haiti Safe: Police Reform,” 11-12.

${ }^{325}$ Joseph Guyler Delva and Daniel Dieujuste, "La Nouvelle Force Militaire Haïtienne Maintenant Effective, Lance Ses Opérations," Haitian Caribbean News Network, February 13, 2014, http://hcnn.ht/fr/2014_01/aide_et_developpement/238/La-nouvelle-force-militaire-haïtienne-maintenanteffective-lance-ses-opérations.htm.

${ }^{326}$ Stephen Baranyi and Yves Sainsiné, “Le Développement de La PNH, La Sécurité Publique et l'État de Droit En Haïti” (Université d'État d'Haïti, Université d'Ottawa, Agence universitaire de la Francophonie, May 15, 2015), 5, https://sciencessociales.uottawa.ca/developpement-internationalmondialisation/nouvelles/professeur-agrege-stephen-baranyi-professeur-yves-sinsine-luniversite-detatdhaiti-ont.
} 
At first, urgent need for emergency relief and humanitarian assistance diverted, with reason, efforts from peace-building activities. MINUSTAH and foreign donors shifted their focus towards disaster response, which pushed aside local peace-building initiatives. ${ }^{327}$ For instance, Viva Rio Haiti abandoned momentarily some of its regular peace-building activities in Bel Air and its surroundings to respond to more pressing humanitarian needs and in accordance with funding availability and requirements. ${ }^{328}$ The NGO received funding from donors to address immediate needs in Bel Air, and parts of those funds were used to employ individuals from the community to work in Viva Rio's installations. In parallel, the Canadian government notified Via Rio in late 2010 that funding for community violence reduction initiatives would not be renewed. A 2009 audit report indicates that the program had produced clear benefits for the community, but faced management and transparency challenges. ${ }^{329}$ As funding for emergency relief dried out and financial support for peace-building programs was not renewed, ${ }^{330}$ Viva Rio lost some of its ability to engage with and influence communities. As a result, tension rose between the NGO, its former employees, and the community more broadly. ${ }^{331}$

Nonetheless, after 2010, many local NGOs continued to contribute to local peace building with the support of foreign donors. Yet, as pointed out by the director of one of

\footnotetext{
${ }^{327}$ Timothy Donais and Amy C. Knorr, "Peacebuilding from below vs. the Liberal Peace: The Case of Haiti," Canadian Journal of Development Studies/Revue Canadienne d\&\#039;études Du Développement 34, no. 1 (2013): 54-69, doi:10.1080/02255189.2013.761130.

${ }^{328}$ CIDA, DFAIT/START, and NCA, “Évaluation Conjointe De 'l'intervention de Viva Rio Dans La Zone de Bel Air’ en Haïti - Appuyée Par l’ACDI, Le MAECI/GTSR et NCA,” May 3, 2011, ii, http://www.vivario.org.br/wpcontent/themes/vivario/bibliotecaepesquisa/relatoriosdeavaliacao/evaluation_de_laction_de_vivario/evaluat ion_intervention_de_vivario_a_bel_air_2011_fr.pdf.

${ }^{329}$ CIDA, DFAIT/START, and NCA, "Évaluation Conjointe De 'l'intervention de Viva Rio Dans La Zone de Bel Air' en Haïti - Appuyée Par l'ACDI, Le MAECI/GTSR et NCA.”

${ }^{330}$ See Ibid.

${ }^{331}$ Interview with the head of programs, Viva Rio Haiti, Port-au-Prince, July 2014.
} 
those initiatives, it is a mere drop in the ocean without significant funding and a real political solution at the national level. ${ }^{332}$ Political instability and uncertainty undermined the ability of these organisations to move forward and implement new initiatives.

Besides and as pointed out earlier, once elected, Martelly refused to engage officially with non-state coercive actors. CNDDR had become inactive after the earthquake and was dismantled following the official resignation of its president Alix Fils Aimé in May 2011. No mechanisms were put in place afterwards to pursue CNDDR's mission and engage with non-state actors and/or formalise public ordering in Port-au-Prince. The lack of appetite from political elites to put in place a comprehensive approach to SSR prevented the re-emergence of broad initiatives comparable to CNDDR. Some local peace-building initiatives remained in place, but available funding was significantly reduced, and most importantly, the pre-earthquake momentum was lost. However, as the next section discusses, events suggest that if the Haitian government no longer engaged officially with non-state actors considered criminal, some of its members maintained covert relations through clientelism and patronage linkages.

Overall, from 2010, SSR became increasingly state-centric, focusing mostly on the reform of the police force. The more inclusive strategy adopted by Préval between 2006 and 2009 was left aside almost completely. These changes took place in a POR that had been profoundly disrupted by the earthquake. The next sections describe the impact of a return to state-centric SSR on the structure of the POR, and its consequences on public order in Haiti.

\subsection{The resulting public order regime: $2011-2015$}

${ }^{332}$ Interview with the executive director, Lakou Lapè, Port-au-Prince, August 2014. 
The post-earthquake POR remained pluralist and vulnerable to disruption. SSR did reinforce the State by strengthening the $\mathrm{PNH}$, but the extreme weakness of the justice system undermined the capacity of the State to effectively provide security and justice to its population, as well as to claim effective control through the POR. MINUSTAH continued to play a crucial role in the provision of basic security, while the re-emergence of local armed groups in popular neighbourhoods of Port-au-Prince periodically undermined security and influenced public order. Hence, SSR under Martelly failed to improve significantly the level of public order produced by the regime.

\subsubsection{State coercive actors}

State capacity in the security sector certainly increased between 2011 and 2015, thanks to continued effort toward the reform of the police and a strong international police and military presence, stabilizing the regime. However, the lack of progress in the justice sector, its incapacity to provide justice due to feeble resources and the absence of political appetite, and continued political resistance to a more transparent and accountable government undermined state-building efforts in and outside the security and justice system. It showed the limits of state formal public ordering in fragile settings, while also fostering informal public ordering.

\subsubsection{Formal public ordering}

Between 2011 and 2015, the PNH is the Haitian institution that showed by far the biggest improvement. ${ }^{333}$ Indeed, the police force made some clear progress in terms of manpower, capacity, and professionalism. By September 2016, it reached a force of

\footnotetext{
${ }^{333}$ Interview with the deputy police commissioner, MINUSTAH, Port-au-Prince, July 2014.
} 
13,200 , including 1,182 women representing 9 percent of the personnel..$^{334}$ This number is under the objective of 15,000 police agents by the end of 2016, which has now been postponed to the end of 2017. According to the September 2015 progress report, recruitment was hampered by administrative slowness, issues with the medical vetting, and financial constraints, as the Haitian government is responsible for covering salaries. ${ }^{335}$ Some members of the police service also expressed concern about selection criteria, deemed too low to ensure that over time new agents will be able to move up the ladder with the right competences. ${ }^{336}$

Second, donor support improved material capacity and specialized expertise. While resources continued to be concentrated in Port-au-Prince, police stations and substations have been built in different departments to extend the State's coverage. Donors have provided vehicles and funded the development of infrastructures, such as the Inspectorate General offices in Port-au-Prince and a maritime base in Les Cayes in the South Department. ${ }^{337}$ In line with the PNH Development Plan, the mechanic maintenance workshop in Port-au-Prince was strengthened and a garage was built in Port-de-Paix in the northeast region of the country. Donors have also provided training in Haiti and abroad for the creation of specialized units and the development of specific expertise, such as gender, community policing, close protection, crowd control, and tactical

\footnotetext{
${ }^{334}$ UN Security Council, "Report of the Secretary-General on the United Nations Stabilization Mission in Haiti (August 2016)" (New York: United Nations, August 31, 2016), 6.

${ }^{335}$ République d'Haïti, "5ème Rapport de Mise En Oeuvre Du Plan de Développement de La PNH 20122016," 17.

${ }^{336}$ Interview with the director of the National Police Academy, Port-au-Prince, August 2016.

${ }^{337}$ Interview with the deputy police commissioner, MINUSTAH, Port-au-Prince, July 2014; interview with the head of the UNPol community policing unit, MINUSTAH, Port-au-Prince, July 2014. See also Baranyi and Sainsiné, "Le Développement de La PNH, La Sécurité Publique et l'État de Droit En Haiti.."
} 
intervention. ${ }^{338}$ Meanwhile, Haitian trainers provided the entire basic training at the national school, ${ }^{339}$ monitored by a small group of UNPol officers.

Third, the PNH also significantly improved in terms of professionalism. Vetting finally started in 2012. As of August 2016, 9,290 files of police officers and civilian staff had been certified, 3,227 cases were still under investigation, and 683 had yet to be opened. ${ }^{340}$ Only a limited number of police agents were not recommended after verification. Yet, the PNH remains an inexperienced institution, with 30 percent of its strength with less than five years of experience in 2016 and significant gaps in its command structure. ${ }^{341}$ The construction of a police academy for the formation of inspectors and commissioners has been repeatedly delayed since $2008 .{ }^{342}$ The academy currently occupies offices adjacent to the police school in Port-au-Prince. Nonetheless, efforts were made to develop the leadership of the institution, through the training and the mentoring of new commissioners. The police academy, funded by the Canadian government, has developed a program for the initial training and professional development of the PNH's managerial staff, through a work-study structure. The objective of the program is to help new police commissioners to put in practice the skills and competences they acquired in class in order to become better managers ${ }^{343}$ It remains to be seen whether police inspectors and commissioners managed to transfer these new competence in their daily activities.

\footnotetext{
338 Ibid.

${ }^{339}$ United Nations, "Report to the Secretary-General on the United Nations Stabilization Mission in Haiti (March 2014)" (United Nations, March 7, 2014).

${ }^{340}$ UN Security Council, "Report of the Secretary-General on the United Nations Stabilization Mission in Haiti (August 2016)," 6.

${ }^{341}$ Interview with the deputy police commissioner, MINUSTAH, Port-au-Prince, July 2014.

${ }^{342}$ Lee Berthiaume, "Canadian Promise to Build Haitian Police Academy in Limbo," Ottawa Citizen, 2014 2014, http://ottawacitizen.com/news/politics/canadian-promise-to-build-haitian-police-academy-in-limbo.

${ }^{343}$ Interview with a Canadian police officer H8, UNPol, MINUSTAH, Port-au-Prince, July 2014.
} 
Some key challenges remained by 2016, however. First, human and material resources were too limited and highly centralized in Port-au-Prince. Infrastructure and personnel in the different departments were extremely limited and impeded on the State's capacity to provide security to its population. Two thirds of the PNH personnel were in the West Department, and police officers could only be found in 261 of the country's 570 communal sections. ${ }^{344}$ UNPol officers often provided basic necessities, including bullets, to the PNH officers with whom they worked. Second, the PNH budget remained highly dependent on donors' contributions, as lack of state revenue and political instability undermined the continuous funding of the $\mathrm{PNH}^{345}$ The institution's budget barely covered the PNH salaries. ${ }^{346}$ Third, a lot of the PNH resources were misused and influenced by political elites. A disproportionate number of PNH agents were assigned to the close protection of politicians and members of government. Vehicles donated to the PNH by the Canadian government to patrol the Haitian-Dominican border were used for personality protection in Port-au-Prince. ${ }^{347}$ Participants have also suggested that Martelly named a new director for the West Department in 2014 because his predecessor was not willing to control and repress public demonstrations against the government. ${ }^{348}$ Fourth and perhaps more significantly, the progress achieved in the development of the PNH has

\footnotetext{
${ }^{344}$ UN Security Council, "Report of the Secretary-General on the United Nations Stabilization Mission in Haiti (August 2016)," 9; Baranyi and Sainsiné, "Le Développement de La PNH, La Sécurité Publique et l'État de Droit En Haïti," 5.

${ }^{345}$ UN Security Council, "Report of the Secretary-General on the United Nations Stabilization Mission in Haiti (August 2016)"; Baranyi and Sainsiné, "Le Développement de La PNH, La Sécurité Publique et l'État de Droit En Haït," 5; International Crisis Group, "Towards a Post-MINUSTAH Haiti: Making an Effective Transition," Latin America/Caribbean Report N 44 (New York: International Crisis Group, August 2, 2012), 5 .

${ }^{346}$ UN Security Council, "Report of the Secretary-General on the United Nations Stabilization Mission in Haiti (August 2016)," 16.

${ }^{347}$ Interview with a Canadian diplomat, Port-au-Prince, August 2014.

${ }^{348}$ Interwiew with a Canadian UNPol, Community Policing Unit, MINUSTAH, Port-au-Prince, July 2014.
} 
not been met in other sectors of the security system. The lack of meaningful reforms in the justice and correctional sectors undermined the sustainability of the police reform. There are important limits to what a professional police force can accomplish without a functioning and transparent justice apparatus to prosecute cases.

Despite calls by MINUSTAH and other donors to implement significant reforms in the justice sector, the situation remained dire. According to the latest Secretary-General Report to the UNSC: "The deficiencies in the justice and corrections systems, prolonged pre-trial detention and the consequent prison overcrowding, widespread corruption, and violations of human rights and due process remain intractable problems." ${ }^{\text {} 349}$ Reforming the penal code has been a slow enterprise. After nation-wide consultations, the Presidential Commission on Justice Reform finally submitted the drafts of the criminal code and the code of criminal procedure to the executive branch in $2016 .{ }^{350}$ Judges at all levels remained poorly trained and subject to political influence, despite some efforts to vet members of the judiciary. Political elites lacked incentives to support justice reform since addressing the many weaknesses of the justice system would require a revision of their privileges and prerogatives. ${ }^{351}$ A 2015 assessment report prepared for USAID illustrates those dynamics:

\footnotetext{
${ }^{349}$ Modest improvements can be witnessed in the training of judges and the development of infrastructure. However, the absence of political will to decentralize justice, lack of transparency and impartiality, and impunity continue to undermine the rule of law. These assessments of justice reform show that the situation in the justice sector remains virtually unchanged between 2010 and 2015: UN Security Council, "Report of the Secretary-General on the United Nations Stabilization Mission in Haiti (August 2016)," 15; TaftMorales, "Haiti Under President Martelly: Current Conditions and Congressional Concerns," 34-35; Robert Maguire, "Providing Justice in Haiti," Peacebrief 122 (Washington, D.C.: United States Institute of Peace (USIP), April 4, 2012), 2; International Crisis Group, "Keeping Haiti Safe: Justice Reform,” Latin America/Caribbean Briefing (Port-au-Prince/Brussels: International Crisis Group, October 27, 2011). ${ }^{350}$ UN Security Council, "Report of the Secretary-General on the United Nations Stabilization Mission in Haiti (August 2016), 7.

${ }^{351}$ Maguire and McCreesh, "The Challenge of Keeping Haitians Safe."
} 
"Haiti lacks a genuine commitment from the executive to serious, sustainable and comprehensive justice reform. In addition, spoilers, such as some law practitioners, land surveyors and notaries (those who benefit the most from legal obscurity and the status quo) have fought justice reform efforts. These groups have kept the sector weak and under-resourced, to insulate themselves from the consequences of questionable legal practices and behaviour and sustain impunity. A strong justice sector threatens the political interests of the elite and its control of Haiti's wealth. It also challenges the benefits gained by the spoilers. ${ }^{, 352}$

Despite the fact that Martelly made the rule of law one of his top priorities, his administration was criticized on many occasions for interfering in the justice sector to advance private interests. ${ }^{353}$ Michel Frost, the former UN Independent Expert on the situation of human rights in Haiti from 2008 to 2013, denounced the situation on several occasions. In an open letter published in Haiti's media upon his demission, he highlights how rule of law seems to be a fuzzy concept for Haiti's politicians and decisionmakers. ${ }^{354}$ Through Martelly's presidency, several of his acquaintances suspected of criminal activities (drug trafficking, arm smugglings, kidnapping, and gangsterism) were arrested only to be released shortly after and to see their charges dropped. ${ }^{355}$ Gross

\footnotetext{
${ }^{352}$ Paul Fitzgerald et al., "Haiti Rule of Law Assessment. Final Report” (USAID, April 2015), i.

${ }^{353}$ Taft-Morales, "Haiti Under President Martelly: Current Conditions and Congressional Concerns," 13. ${ }^{354}$ Michel Frost, "Haiti/Droits Humains: Lettre Ouverte de Michel Forst Aux Haïtiens !," Canal Plus Haiti, March 27, 2013, http://www.canalplushaiti.net/haitidroits-humains-lettre-ouverte-de-michel-forst-auxhaitiens/.

${ }^{355}$ See, for instance, the cases of Woodley Ethéart, Calixte Valentin, and Évinx Daniel covered in John Lee Anderson, "Aftershocks: Haiti Since the Earthquake," The New Yorker, February 1, 2016, http://www.newyorker.com/magazine/2016/02/01/aftershocks-letter-from-haiti-jon-lee-anderson; Frances Robles, "Haitian Leader's Power Grows as Scandals Swirl,” The New York Times, March 16, 2015, http:/www.nytimes.com/2015/03/17/world/americas/haitian-president-tightens-grip-as-scandal-engulfscircle-of-friends.html; Taft-Morales, "Haiti Under President Martelly: Current Conditions and Congressional Concerns," 33; RNDDH, “Illicit Drug Trafficking: The Government of Martelly/Lamothe
} 
irregularities during the investigation and political pressure on judges seem to have been at play in most cases. Political interference in arrests and detentions is also reported by UNPol officers who were in co-location with the PNH in police stations in Port-auPrince. ${ }^{356}$ As a result, the lack of progress along the criminal justice chain has undermined the development of the PNH. Informal discussions with PNH agents revealed that they often feel powerless when it comes to the application of the law. This hampered the formalisation of state public ordering, which will be discussed thereafter.

When it comes to the prison system, conditions of detention continued to be horrid, despite efforts from the MINUSTAH's rule of law and human rights offices. In 2015, 70.9 percent of the prison population was composed of pre-trial detainees, attesting of the ineffectiveness of the criminal justice chain. Furthermore, despite external efforts to address prison overcrowding, penitentiary population has steadily increased from 5,331 inmates in 2010 to 10,830 inmates in $2015 .{ }^{357}$ The construction of a new prison in Croixdes-Bouquets near Port-au-Prince has failed to reduce the occupancy rate in the prison system, which was still over 400 percent in $2016 .{ }^{358}$

Finally, despite significant progress, the UNSC continues to consider that the PNH "are not yet operationally independent and continue to rely on international support, including from MINUSTAH, in fulfilling their constitutional mandate." ${ }^{359}$ Throughout the period, MINUSTAH military personnel patrolled hot zones, and punctual operations

Makes Every Effort to Protect Drug Traffickers close to Power," September 19, 2013, http://rnddh.org/content/uploads/2013/09/Rapport-Drogue-Sud-18-sep-2013-AN.pdf.

${ }^{356}$ Interview with a Canadian UNPol officer H9, Port-au-Prince, Haiti, July 2014.

${ }^{357}$ UN Security Council, "Report of the Secretary-General on the United Nations Stabilization Mission in Haiti (August 2016)," 6; Institute for Criminal Policy Research, "Haiti I World Prison Brief," World Prison Brief, 2015, http://www.prisonstudies.org/country/haiti.

${ }^{358}$ UN Security Council, "Report of the Secretary-General on the United Nations Stabilization Mission in Haiti (August 2016)," 6.

${ }^{359}$ Ibid., 14. 
against local gangs and armed groups usually involved MINUSTAH police and military personnel in support to the PNH. For instance, Operation Phoenix involved over 2,100 MINUSTAH personnel in a series of operations in Cité Soleil, Bel Air, and Martissant in July $2011 .{ }^{360}$ In June and July 2014, anti-gang operations were conducted in Cité Soleil, with the support of MINUSTAH. It could be argued that the strong MINUSTAH presence and its readiness to contribute to security in Haiti actually also hampered the development of Haiti's security sector. For example, the former deputy police commissioner pointed out that MINUSTAH and its Haitian counterparts relied on JMAC for intelligence and analysis rather than pushing for the development of a similar body within the PNH. ${ }^{361}$

All in all, formal public ordering remained limited, despite the professionalization of the PNH. Even when the number of police agents will reach 15,000 police officers, the state security capacities will remain limited in many departments. Furthermore, without progress in the justice sector, it is unlikely that police reform alone will suffice to the transformation of security and justice in Haiti. While some experts argue that it is mostly a question of numbers and capacities, ${ }^{362}$ others suggest that much more is required to ensure the sustainability of the reform process and a true transformation of security and justice in Haiti. ${ }^{363}$ Indeed, enduring corruption among state security institutions and informal public ordering suggest that progress in the development of professional, effective, independent, and transparent institutions accomplished so far remain fragile.

\footnotetext{
${ }^{360}$ International Crisis Group, "Keeping Haiti Safe: Police Reform,” 6.

${ }^{361}$ Interview with deputy police commissioner, MINUSTAH, Port-au-Prince, July 2014.

${ }^{362}$ Interview with deputy police commissioner, MINUSTAH, Port-au-Prince, July 2014; Interview with the head of programs, Viva Rio Haiti, Port-au-Prince, July 2014.

${ }^{363}$ Interview with the director of the National Police Academy, Port-au-Prince, August 2016 ; interview with the executive director, Lakou Lapè, Port-au-Prince, August 2014.
} 


\subsubsection{Informal public ordering}

Despite the reinforcement of the PNH, Haiti's state security and justice institutions faced important limits in their capacity to provide security to Haitians through formal means. In that context, informal public ordering by state actors continued to occur, resulting in extrajudicial violence and undermining the formal security and justice system. State political actors also engaged in patronage with local armed groups, which will be discussed under non-state public ordering.

Pre-trial detention became a vehicle for a parallel system of bribes. People who should not be detained were put in preventive detention to sustain a bribe market involving local judiciary authorities. According to Brian Concannon, director of the Institute for Justice and Democracy in Haiti, "the biggest obstacle [to cases being processed] is that the high rate of pre-trial detention is a way of creating a market for bribes. ${ }^{364}$ Corruption and political interference "[keep] people in prison who should [not] be, but also lets (sic) people who should be in prison out. It means police would legitimately think twice before arresting a 'real' criminal." ${ }^{365}$ In 2014, more than two thirds of Haitians had been solicited to pay a bribe. ${ }^{366}$ Yet, interestingly enough, "[in] Haiti, the perception of corruption is rather low, relative to that of the United States and other countries in Latin America. This relatively low perception of corruption can be attributed to the fact that most bribes (given and taken) are not perceived as corruption by

\footnotetext{
${ }^{364}$ Jason O’Brien, "Haiti Special Report: Corruption Means Many Prisoners Wait Years for Trials," Independent.ie, February 15, 2014, http://www.independent.ie/world-news/americas/haiti-special-reportcorruption-means-many-prisoners-wait-years-for-trials-30011805.html. ${ }^{365}$ Ibid.

${ }^{366}$ François Gélineau and Elizabeth J. Zechmeister, "La Culture Politique de La Démocratie En Haïti et Dans Les Amériques 2014: La Gouvernance Démocratique Au Fil Des 10 Ans Du Baromètre Des Amériques" (LAPOP, Americas Barometer, Vanderbilt university, April 2016), 123.
} 
the public but as 'job-related business'. ${ }^{\prime 367}$ This statement illustrates how deep corruption runs in the Haitian justice sector and political system, and the extent to which the formal and the informal are intertwined.

These impediments on the judicial process have consequences on the development of the PNH. Baranyi and Sainsiné described how police officers they interviewed often felt frustrated, as they had to execute mandates for detention that had been issued without consideration for the Haitian law ${ }^{368}$ which contradicted with the training their received and the rules they ought to follow. The limits of the State's security and justice institutions also explained in part the persistence of extrajudicial violence. In communities where informal rules deriving from private interests and corruption of state officials eclipsed the rule of law, PNH agents sometimes acted unlawfully, supporting the system in place, dispensing summary justice, or using disproportionate violence. In the 2011 Report on Human Rights Practices for Haiti, the U.S. Department of State notes instances of extrajudicial violence, arbitrary killings, and torture by government officials. ${ }^{369}$ The 2015 edition of the same report suggests improvements, but notes "isolated allegations of police and other government officials' involvement in arbitrary or unlawful killings.. ${ }^{370}$

A national NGO for the protection of human rights, the National Human Rights Defense Network (known by its French acronym RNDDH), also reported in several

\footnotetext{
${ }^{367}$ Fitzgerald et al., "Haiti Rule of Law Assessment. Final Report," 3.

${ }^{368}$ Baranyi and Sainsiné, "Le Développement de La PNH, La Sécurité Publique et l'État de Droit En Haïti," 10 .

${ }^{369}$ U.S. Department of State, "Haiti 2011 Human Rights Report," Country Reports on Human Rights Practices for 2011 (Washington, D.C., May 24, 2012), http://www.state.gov/j/drl/rls/hrrpt/2011/wha/186522.htm.

${ }^{370}$ U.S. Department Of State, "Haiti 2015 Human Rights Report," Country Reports on Human Rights Practices for 2015 (Washington, D.C.: U.S. Department of State, Bureau of Diplomatic Security, 2016), 2, http://www.state.gov/j/drl/rls/hrrpt/humanrightsreport/index.htm?year=2015\&dlid=253021.
} 
instances the unjustified use of force and inhuman treatments by the $\mathrm{PNH}$ and its specialised units against the population. ${ }^{371}$ For example, police agents from the Departmental Operation and Intervention Brigade committed exactions - detention without motive, vandalism, theft, and looting - against the population of Arcahaie who had demonstrated against the redefinition of the commune's borders. ${ }^{372}$

Nonetheless, disciplinary mechanisms inside the PNH have been reinforced as part of the 2012-2016 Development Plan. Police agents were taken off duty and assigned to deskwork following complaints of misconduct, suggesting that internal control mechanisms are being applied. ${ }^{373}$ However, “the low percentage of officers recommended for dismissal for human rights violations and crimes is consistent with the public's perception of corruption in the institution." 374

Widespread corruption within the justice system and extrajudicial violence perpetrated by state agents illustrate the limits of state formal public ordering and the persistence of informal public ordering. An evaluation report for USAID programs targeting the rule of law puts it well: "the Haitian State is captured in a web of patronage relations that does not fall within its formal/legal jurisdiction., ${ }^{375}$ Informal public ordering is not limited to state actors, however. Despite the strong adversarial stand adopted publically by Martelly, evidence suggests that members of his government maintained covert relations with non-state armed groups, which influenced public order

\footnotetext{
${ }^{371}$ See, for instance, RNDDH, "Rapport Sur Les Événements Survenus À Cité Soleil Le 16 Octobre 2015" (Port-au-Prince: RNDDH, November 20, 2015), http://rnddh.org/content/uploads/2015/11/9-Cit\%C3\%A9Soleil-Nov-2015.pdf; RNDDH, "Rapport D'enquête Sur La Situation de Tension À 1'Arcahaie" (Port-auPrince: RNDDH, October 14, 2015), http://rnddh.org/content/uploads/2015/10/8-Arcahaie-14-octobre20151.pdf.

${ }^{372}$ RNDDH, "Rapport D’enquête Sur La Situation de Tension À l’Arcahaie.”

${ }^{373}$ International Crisis Group, "Keeping Haiti Safe: Police Reform,” 7.

${ }^{374}$ Ibid., 8.

${ }^{375}$ Fitzgerald et al., "Haiti Rule of Law Assessment. Final Report," 1.
} 
at the local level, especially in popular neighbourhoods of Port-au-Prince. Hence, the line between the state and the non-state in informal public ordering is often blurred.

\subsubsection{Non-state coercive actors}

Despite SSR efforts targeting state institutions, the Haitian POR after 2011 remained pluralist. In 2014, approximately 25 percent of Haitians considered that gangs affected their community ${ }^{376}$ Interviews conducted in Haiti the same year with representatives of NGOs and international agencies show how complex the public ordering landscape in Haiti was. Most participants talked about bases, organisations populaires (popular organisations), gangs, cellules communautaires (community cells), armed bands, and community leaders when asked about local security and governance. Yet, there was a lack of consensus surrounding who compose these different groups and the role they played at the local level. Furthermore, labels varied and were not mutually exclusive.

Despite this lack of clarity, what was particularly striking from my conversations with these organisations was the limited formal reach of the State in popular neighbourhoods. In a 2012 article, Kivland describes how Haitians in popular neighbourhoods of Port-auPrince experienced statelessness, in the form of a weak government unable to fulfill its Weberian role and the disorganized presence of multiple national and foreign agencies providing a mishmash of services and making for "disordered governance." ${ }^{377}$ To that, I add that covert relations between politicians and local armed groups have played a key role in the management of communities' security and public order. While these relations have prevailed through most of Haiti's recent history, the impact of those relationships on

\footnotetext{
${ }^{376}$ Gélineau and Zechmeister, "La Culture Politique de La Démocratie En Haïti et Dans Les Amériques 2014: La Gouvernance Démocratique Au Fil Des 10 Ans Du Baromètre Des Amériques,” 159.

${ }^{377}$ Kivland, "Unmaking the State in 'Occupied' Haiti."
} 
public order was particularly striking under the Martelly administration. Despite international actors pushing for state formalisation and expansion, formal state presence continued to be limited and local armed groups often filled the resulting gap in the POR, sometimes sponsored by politicians and other elites.

\subsubsection{Local armed groups}

As described earlier, the earthquake destabilized many communities and had lasting consequences on the distribution of authority at the local level, explaining conflict outbursts between local armed groups from 2010 to $2013 .{ }^{378}$ A new generation of local leaders emerged, as a result of the lack of employment and other opportunities. ${ }^{379}$ These young leaders, for the most part teenagers, were perceived as not respecting existing forms of authority. As a result, old and new leaders competed over territorial control. ${ }^{380}$ Interviews and a review of national newspapers revealed that clashes between local armed groups occurred periodically during that period, influencing public order and the daily life of communities. ${ }^{381}$

In an interview conducted in the summer of 2014, a UNPol officer who had been assigned to co-location activities with the PNH in Cite Soleil kept repeating the same

\footnotetext{
${ }^{378}$ Interview with the head of programs, Viva Rio Haiti, Port-au-Prince, July 2014. See also Athena R. Kolbe and Robert Muggah, "The Economic Costs of Violent Crime in Urban Haiti: Results from Monthly Household Surveys, August 2011-July 2012," Strategic Note (Rio de Janeiro: Igarapé Institute, September 2012); Muggah and Kolbe, "In Haiti, Violence amid the Rubble."

${ }^{379}$ Interview with the executive director, Lakou Lapè, Port-au-Prince, August 2014.

${ }^{380}$ Interview with the head of programs, Viva Rio Haiti, Port-au-Prince, July 2014.

${ }^{381}$ See, for instance, Roberson Alphonse, "Croix-Des-Bossales et Martissant, Comme Des Volcans En Activité," Le Nouvelliste, February 18, 2016, http://lenouvelliste.com/lenouvelliste/article/155702/Croixdes-Bossales-et-Martissant-comme-des-volcans-en-activite; RNDDH, "Rapport Sur Les Événements Survenus À Cité Soleil Le 16 Octobre 2015"; Juno Jean Baptiste, "Marché de La Croix-Des-Bossales, Spirale de Terreur," Le Nouvelliste, August 22, 2014, http://lenouvelliste.com/lenouvelliste/article/134641/Marche-de-la-Croix-des-Bossales-spirale-deterreur.html; Jean Daniel Sénat, "Le Présumé Chef de Gang Gabriel Jean Pierre Appréhendé À Cité Soleil," Le Nouvelliste, September 4, 2014, http://lenouvelliste.com/lenouvelliste/article/135390/Le-presume-chefde-gang-Gabriel-Jean-Pierre-apprehende-a-Cite-Soleil.html.
} 
statement: "there is no police in Cité Soleil. ${ }^{382}$ He explained in detail how the PNH did not really patrol outside the police station, for a lack of adequate equipment and a highly volatile security situation. MINUSTAH had an advanced military post adjacent to the police station and its troops patrolled the zone regularly, but they always followed the same route and rarely entered communities that could not be accessed in vehicles. Hence, the effective presence of the State in Cité Soleil was limited. In its place, local gangs established the rules of the game, dictating to some extent individuals' behaviours. Wellarmed gangs controlled different zones. According to the same UNPol officer, people believed that gangs took care of them, or at least provided some form of protection to their community.

This perspective is consistent with research on community-based armed groups in Port-au-Prince. In contrast to other non-state armed actors active in Haiti (ex FAd'H, private militias, and other criminal networks), Athena Kolbe considers that "urban gangs usually provide services to residents including assisting with medical care or burial costs, paying tuition fees for disadvantaged children, garbage collection, home repair, and the organisation of social and musical events. ${ }^{.383}$ Moritz Schubert's research also illustrates the dual function of community-based armed groups: the same organisation can be perceived as a legitimate civil organisation by some stakeholders and as a predatory gang by others. ${ }^{384}$ Yet, their control over poor neighbourhoods of Port-au-Prince is undeniable. It is extremely difficult for aid workers to access communities controlled by these groups

\footnotetext{
${ }^{382}$ Interview with a Canadian police officer H9, MINUSTAH, Port-au-Prince, July 2014.

${ }^{383}$ Kolbe, "Revisiting Haiti’s Gangs and Organized Violence," 4.

${ }^{384}$ Schuberth, "Growing the Grassroots or Backing Bandits?"; Schuberth, "A Transformation from Political to Criminal Violence?"
} 
"without direct contact with gang leaders. ${ }^{" 385}$ Some organisations such as Viva Rio Haiti have been open about how they engage gang or community leaders. Yet, this issue is clearly seen as delicate by other NGOs involved, as some were somewhat reluctant to discuss their activities and others refused altogether to do it.

Based on their capacity and willingness to use force, local armed groups also managed to influence the informal economy at the community level. This is critical, considering that more than two-thirds of Haitians do not have formal employment, and that there are only 200,000 formal jobs for a workforce of almost five millions. ${ }^{386}$ Consequently, in popular neighbourhoods, the informal economy is key to survival and represents the main source of income for most individuals and families. Protection rackets were common and widespread. For instance, "to be a vendor in Cité Soleil, you have to pay the gangs. ${ }^{387}$ The situation was similar in the market of Croix-des-Bossales, the centre of Port-au-Prince's economic life. Over the years, different armed groups have shared or competed for the control of the market and its revenue. A former administrator of the market indicated that violence tends to be cyclical. It would increase in the summer, when the harvest would bring more merchants and resources to the market. ${ }^{388}$ These dynamics are not isolated from the State, however. Patronage linkages between politicians and local armed groups have significantly influenced security and public order since 2011.

\footnotetext{
${ }^{385}$ Schuberth, "Growing the Grassroots or Backing Bandits?," 3.

${ }^{386}$ Central Intelligence Agency, "Central America and Caribbean: Haiti," The World Factbook, November 3, 2016, https://www.cia.gov/library/publications/the-world-factbook/geos/ha.html; Taft-Morales, "Haiti Under President Martelly: Current Conditions and Congressional Concerns," 12.

${ }^{387}$ Interview with a Canadian police officer H9, UNPol, MINUSTAH, Port-au-Prince, July 2014.

${ }^{388}$ Interview with a project director, Viva Rio Haiti, Port-au-Prince, August 2014.
} 


\subsubsection{Patronage relations}

Patronage relations between political figures and local armed groups subsisted despite formalisation efforts under SSR. While political actors are not coercive actors per se, during the period studied, they reinforced community-based armed groups through sponsorship and protection from formal public ordering. Hence, although they did not directly claim control over the means of violence in the POR, they managed to influence indirectly how force was used and which rules and norms were enforced. Local and national politicians hired local gangs to rule specific zones, funded their campaign through racketing, and control both electoral polls and local vote through the use of brute force or its threat. ${ }^{389}$ These relationships perverted public order, showing both the limits of SSR and the complexity of public order in Haiti.

The case of Almetis Junior Saint-Fleur, former legislative representative for Cité Soleil, illustrates well the collusion between politicians and local armed groups. In June 2014, UNPol officers in colocation at the police station in Cité Soleil organized a series of joint operations against gang leaders following information received from informants paid by the MINUSTAH. The operations led to the arrest of Iska, the strongman in Belekou, a community of Cité Soleil. Saint-Fleur was on location when Iska was apprehended. The next day, people from Belekou demonstrated outside the police station of Cité Soleil. Saint-Fleur entered the station and threatened at gunpoint one of the UN police officers, telling him to not get involved in Haitian affairs ${ }^{390}$ Both UNPols had to be transferred to other positions as their personal security was now at risk.

\footnotetext{
${ }^{389}$ Interview with the executive director, Lakou Lapè, Port-au-Prince, August 2014.

${ }^{390}$ Interview with a Canadian police officer H9, UNPol, MINUSTAH, Port-au-Prince, July 2014.
} 
The reliance of political elites on local gangs seems particularly acute during electoral periods. ${ }^{391}$ This pattern has been observed and documented by other researchers. In his research on the logic of armed group violence in Haiti, Moritz Schuberth argues that nonstate armed actors in Haiti go back and forth between political and criminal violence based on demand by political patrons. ${ }^{392}$ According to a UN official interviewed by Schuberth, "when elections are approaching, [conflicts] will intensify. That's why there are currently many power struggles, [because] every group is trying to position itself." 393 Between 2011 and 2015, recurring electoral delays meant that every time elections would be announced, political actors would hire local armed bands, feeding into competition and friction over territorial control.

During my field research in the summer of 2014, the organization of long delayed legislative elections and the beginning of the presidential campaign monopolized most discussions. Postponed since 2011, legislative and municipal elections were planned for October 2014. ${ }^{394}$ Many local stakeholders expected an increase in violence as elections approached and competition between political candidates became more acute. They attributed clashes between gangs to frictions between groups sponsored by politicians to

\footnotetext{
${ }^{391}$ U.S. Overseas Security Advisory Council, "Haiti 2016 Crime \& Safety Report” (Washington, D.C.: U.S. Department of State, Bureau of Diplomatic Security, March 1, 2016), 2, https://www.osac.gov/pages/ContentReportDetails .aspx?cid=19193.

${ }^{392}$ Schuberth, "A Transformation from Political to Criminal Violence?"

${ }^{393}$ Interview conducted by Moritz Schuberth with MINUSTAH official, Port-au-Prince, 28 October 2013. See Ibid., 179.

${ }^{394}$ Elizabeth Gonzales, “2014 Election Blog: Haiti’s October Legislative Elections in Doubt," Americas Society/Council of the Americas, July 15, 2014, http://www .as-coa.org/blogs/2014-election-blog-haitisoctober-legislative-elections-doubt.
} 
secure territorial control. ${ }^{395}$ Several events that occurred over that period support this claim and illustrate the capacity of local gangs to dictate public order at the local level.

In the market of Croix-des-Bossales, violence ramped up through the summer. ${ }^{396}$ The number of homicides and robberies had increased and most people who would raise the topic said that crime was the result of hostilities between two local gangs for the control of the market. ${ }^{397}$ Local politicians were arming gangs to capture control over the market and its revenue, which led to attacks on local merchants and an increase in thefts and robberies at night. According to people I met in the market in August during a visit with MINUSTAH military troops and members of the civil society, the PNH was hardly visible, and the lack of state presence provoked fear among the population. ${ }^{398}$

During the same period, the zone of Martissant was also affected by competition between local armed groups. ${ }^{399}$ Interestingly enough, one of the main gangs in Martissant at the time was named Tet Kale, which is also the name of Martelly's political party. According to the executive director of the Lakou Lapè organisation, which has been active in Martissant for years, violence in the zone was due to political competition: "territorial control has been one of the main issues at stake between bases in Martissant. [...] There is an established system that allows people to fund these groups to control

\footnotetext{
${ }^{395}$ Commission Episcopale Nationale Justice et Paix, "Violence Dans La Zone Métropolitaine de Port-AuPrince" (Port-au-Prince: Commission Episcopale Nationale Justice et Paix, March 10, 2015), 3 and 13.

${ }^{396}$ Baptiste, "Marché de La Croix-Des-Bossales, Spirale de Terreur"; Visite de Sandra HONORE a Cite Soleil / Marché de La Croix Des Bossales, 2014, https://www.youtube.com/watch?v=t8qbL2up3HY\&feature=youtube_gdata_player.

${ }^{397}$ Interview with the head of programs, Viva Rio Haiti, Port-au-Prince, July 2014.

${ }^{398}$ Interview with a program director, Viva Rio Haiti, Port-au-Prince, August 2014.

${ }^{399}$ Radio Kiskeya, "Grand-Ravine : Le Chef de Gang Doy Junior Assassiné, Trois Mois Après Son Prédécesseur « Ti Kenkenn »," Radio Kiskeya, October 19, 2014, http://www.radiokiskeya.com/spip.php?article10245; Danio Darius, "Les Bandits Sèment La Terreur À Martissant," Le Nouvelliste, June 25, 2014, http://lenouvelliste.com/lenouvelliste/article/132718/Lesbandits-sement-la-terreur-a-Martissant.
} 
territory. If I pay this group, and I pay it well, [...] I know that they will allow for my name to be in the ballot boxes and I could even manage to make sure that there is no other name in the ballot boxes."

Finally, in a report on violence in Cité Soleil in October 2015, RNDDH describes how over the years in Cité Soleil, competition between political actors turned into a fight for the control of the commune, using a wide range of strategies from electoral promises to the distribution of weapons and money to local gangs: "today, gangs proliferate in Cité Soleil, making this commune a dangerous place due to the perpetration of acts of violence particularly during struggles for [political] hegemony." ${ }^{401}$

The examples given here are certainly extreme and are not representative of the entire country, or even of Port-au-Prince as a whole. However, they illustrate how, on the one hand, non-state armed actors continue to play a key role in security and public order in popular neighbourhoods of Port-au-Prince, and how, on the other hand, the line between the state and the non-state is not always clear. In sum, from 2011 to 2015, non-state informal public ordering remained common and a complex network of more or less covert gateways linked formal and informal power structures despite the continuous presence of MINUSTAH, the reinforcement of the PNH, and Martelly's pledge against organised crime.

Overall, the POR in Haiti remained pluralist during Martelly's presidency. SSR failed to address not only the entire regime and its highly complex nature, but also the state security system as a whole. As a result, a reinforced but still fragile police force remained isolated, unsupported by the rest of the judicial system that remained mostly ineffective.

\footnotetext{
${ }^{400}$ Interview with the executive director, Lakou Lapè, Port-au-Prince, August 2014.

${ }^{401}$ RNDDH, "Rapport Sur Les Événements Survenus À Cité Soleil Le 16 Octobre 2015.”
} 
MINUSTAH was still necessary to maintaining order in Port-au-Prince. Informal public ordering by state and non-state actors continued to prevail and likely constituted the main source of public order and security for most Haitians. As a result, the POR remained highly volatile and vulnerable to disruption of all sorts.

\subsection{Resulting level of public order, 2011-2015}

In this case more than in any other covered in this dissertation, a lot of factors influenced the level of public order. Accounts of safety and security for that period vary widely and conflicting narratives are common, making for a rather complex assessment of the security situation. For instance, during the summer of 2014, I witnessed tensions between the MINUSTAH's police and military components over divergent assessments of the security situation. For the police commissioner, the PNH was now capable of progressively taking complete charge of public order and security provision in a relatively stable environment. In contrast, the force commander considered the security situation too fragile to reduce the number of UN troops and their role in the management of public order. The U.S. provided a similar assessment; the State Department's Bureau of Diplomatic Security opens its 2016 report on the crime and safety situation in Haiti with the following statement: "[c]rime statistics are woefully underreported by the Haitian National Police (HNP), and reports indicating that Haiti is statistically safer than other countries in the Caribbean are inaccurate. ${ }^{{ }^{402}}$ Yet, qualitative accounts of safety and security by Haitians suggest that the situation was not so dire, as security did not constitute the main concern of Haitians.

\subsubsection{Numbers and statistics}

${ }^{402}$ U.S. Overseas Security Advisory Council, "Haiti 2016 Crime \& Safety Report." 
Limited data availability also limits our capacity to draw a clear portrait of the level of public order in Haiti between 2011 and 2015. Nonetheless, what data are available suggest that the security situation in Haiti and especially Port-au-Prince was volatile during that period. According to numbers gathered by JMAC, body count ${ }^{403}$ varied widely from one month to the other, and variation was clearly driven by the West Department where is located Port-au-Prince. Indeed, other sources consider that 70 percent of homicides perpetrated in 2015 occurred in Port-au-Prince. ${ }^{404}$ Also according to MINUSTAH numbers presented in table 4, body count increased over that period, with a slight decrease in 2013. Regarding kidnappings, their occurrence increased from 2010 to 2012 (between 150 and 200 each year) in comparison to the level of $2009 \cdot{ }^{405}$ Kidnappings then declined in 2013 and 2014 (76 and 30 kidnappings respectively).

Table 4 Annual body count, 2007-2015

\begin{tabular}{|l|c|c|c|c|c|c|c|c|c|}
\hline Year & 2007 & 2008 & 2009 & 2010 & 2011 & 2012 & 2013 & 2014 & 2015 \\
\hline Body count & 486 & 498 & 598 & 677 & 914 & 1033 & 817 & 1084 & 1017 \\
\hline
\end{tabular}

Source: JMAC, MINUSTAH

It is important to note two things when considering these data. First, as noted by the US State department and as discussed in the methodological chapter, crime is likely widely underreported and statistics are more useful to understand trends than absolute levels. For instance, in a trimestral report, Pax Christi, the International Catholic Peace Movement, states: "the exact number of victims is hard to account for, since the bodies of

\footnotetext{
${ }^{403}$ JMAC collects body count data rather than homicide data. See discussion in the methodological chapter, section 4.3.2.3.

${ }^{404}$ Ibid.

${ }^{405}$ JMAC kidnappings data available with the author.
} 
people killed are often buried by gangs without any further do." ${ }^{406}$ Over and over again, UNPol officers described to me how they would accompany the PNH to a crime scene only to find pools of blood, but no corpse. Bodies would be thrown in the sea, burned under piles of tires, or left to be eaten by roaming pigs. Yet, these practices did not only concern violent deaths. In areas where the PNH presence was scattered at best, people would burry the dead without reporting them to the authorities.

Second and in contrast, we cannot ignore the possibility that the quality of data collection increased over the years, as fewer resources were monopolized by the response to the earthquake and MINUSTAH became better at gathering data. Such an improvement would likely result in higher crime numbers. Additionally, the International Crisis Group notes that increased reports of violence to the PNH may suggest greater confidence in the institution. Nonetheless, "it also shows that crime and violence remain serious citizen concerns that potentially can damage governance and economic recovery. ${ }^{407}$

Overall, data only allow us to conclude that the level of public order produced by the regime between 2010 and 2015 was volatile and subject to disruption. Furthermore, if weaknesses in data collection support the idea that crime and violence are underreported, it is difficult to assess the extent of unreported data. JMAC still estimates it can accounts for 85 percent of violent crime perpetrated in the country, present a more optimistic perspective.

\footnotetext{
${ }^{406}$ Commission Episcopale Nationale Justice et Paix, "Violence Dans La Zone Métropolitaine de Port-AuPrince," 13.

${ }^{407}$ International Crisis Group, "Keeping Haiti Safe: Police Reform," 1-2.
} 
Dismissing any regional comparison might also be a going step too far. For 2012, the last year data for Haiti are made available by UNODC, Haiti presents a homicides rate of 10 per 100,000 population, which is well below the regional average of 21.94. In comparison, Dominican Republic, Haiti’s neighbour, presents a homicide rate of 22.3 and Jamaica witnessed 39.8 murders per 100,000 people for the same year. ${ }^{408}$ Even if only one out of two homicides were reported in Haiti in 2012, the country's murder rate would remain well under the regional average. While caution is necessary when discussing available data for Haiti, dismissing any form of regional comparison is far fetched. Nonetheless, it certainly highlights how homicide as a measure of violence and security or lack thereof is insufficient to evaluate the level of public order produced by PORs in fragile states.

\subsubsection{Qualitative assessment}

Qualitative assessments of the security situation in Haiti between 2011 and 2015 shed new light on numbers and statistics. On the one hand, variation and volatility in homicide numbers is transposed to qualitative accounts of security. Violence is usually "confined to known hotspots, but sporadically spills over the broader metropolitan area of the capital." ${ }^{409}$ For instance, in 2012 , different reports suggested that insecurity was rising. ${ }^{410}$ In his open letter to Haitians, the outgoing UN Special Envoy for Human Rights warned that "in the security domain, the situation has worsened, the number of violent deaths by

\footnotetext{
${ }^{408}$ UNODC, "Intentional Homicide, Count and Rate per 100,000 Population (2000-2013)" (United Nations Office in Drugs and Crime, May 18, 2016).

${ }^{409}$ International Crisis Group, "Keeping Haiti Safe: Police Reform,” 2.

${ }^{410}$ Kolbe and Muggah, "The Economic Costs of Violent Crime in Urban Haiti: Results from Monthly Household Surveys, August 2011-July 2012."
} 
gunshot wounds and stabbing is impressive, and fear has returned." ${ }^{\text {"11 }}$ The Government of Haiti, in the first report on the implementation of the PNH Development Plan, also recognized that the feeling of insecurity was tangible at the end of 2012 following the assassination of PNH officers and a series of kidnappings. ${ }^{412}$

Yet, despite this volatile environment, security was not the main concern of the population. In 2014 , only 4.5 percent of Haitians identified security as their main concern, the lowest percentage across the Americas. ${ }^{413}$ The perception of insecurity was more acute in Port-au-Prince than anywhere else in the country, but a majority a Haitians also considered that their neighbourhood was safer than others, and safer than in previous years. ${ }^{414}$

In sum, while homicide statistics suggest that the security situation in Haiti worsened between 2011 and 2015, a broader assessment rather attests of modest improvements. Despite a weak state security apparatus and the complexity of the POR, the regime managed to produce sufficient public order to prevent uncontrollable rises in violence and crime, notwithstanding significant variation in the level of public over time and across communities. Pluralism and the limited reach of the State explain in part why violent conflicts could tear apart a community while neighbouring zones remained relatively peaceful. It is also likely that the UN military presence played a key role in ensuring that the level of public order did not fall under a certain threshold. Nonetheless, the POR remained highly volatile and vulnerable to shocks and disruption, such as elections.

\footnotetext{
${ }^{411}$ Frost, "Haiti/Droits Humains: Lettre Ouverte de Michel Forst Aux Haïtiens !"

${ }^{412}$ Government of Haiti, "Premier Rapport de La Mise En Oeuvre Du Plan de Développement de La Police Nationale d'Haïti 2012-2016 (Septembre 2012-2016)” (Governement of Haiti, February 6, 2013), 5.

${ }^{413}$ Gélineau and Zechmeister, "La Culture Politique de La Démocratie En Haïti et Dans Les Amériques 2014: La Gouvernance Démocratique Au Fil Des 10 Ans Du Baromètre Des Amériques,” 157. ${ }^{414}$ Ibid., 158.
} 


\subsection{Conclusion}

From 2006 to 2009, all the conditions came together to support SSR and violence reduction in Haiti, which was reflected in a significant improvement in security, especially in Port-au-Prince. After the earthquake however, many of those conditions disappeared. First and foremost, the earthquake severely destabilised the POR and altered its structure, which had direct consequences on the level of public order. New actors emerged and old ones that had been neutralized through anti-gang operations returned to their community. At the same time, the earthquake hampered the State's limited capacities and reduced for some time MINUSTAH policing capabilities. On top of that, donors' priorities changed, in part due to the disasters and the emergency relief required.

Following the election of President Martelly, the priority of Haitian officials became development, without much consideration for security. ${ }^{415}$ Despite early commitment to improve the rule of law, little progress was accomplished in the reform of the judicial system. Haitian politics went from one crisis to another, unable to provide a stable political framework in which progress could be achieved and sustained. The momentum created by peace-building efforts between 2007 and 2009 had vanished.

As a result, Haiti remains a fragile state and its government does not successfully claim a monopoly over the means of violence, despite 12 years of intervention in the security sector. Public ordering continues to be a plural affair involving both state and non-state actors engaging in formal and informal activities, and state formal public ordering is still limited. Clientelism and patronage relations influence public ordering and might well undermine any effort to improve and formalize public order if they are not

\footnotetext{
${ }^{415}$ Interview with the deputy police commissioner, MINUSTAH, Port-au-Prince, July 2014.
} 
taken into consideration more systematically by those who design and implement security sector reform.

In this context, state-centric SSR is misguided and will not improve sustainably the level of public order since it does not take into consideration the entire spectrum of actors and mechanisms providing security and producing public order. Strategies adopted under Préval strongly suggest that addressing the role and the place of non-state actors in public ordering can improve the level of public order, prevent violence, and contribute significantly to the country's stability. However, these efforts have remained ad hoc, relying on donors' short-term funding and priorities, as well as political will. The change of strategy under Martelly has certainly contributed to the current volatility of public order in Haiti, and the fluctuating levels of violence. Without strong national political will and a comprehensive approach building on the entire POR, SSR is unlikely to succeed in the long run in Haiti and enable all Haitians to live in a safe and secure environment. 


\section{Chapter: El Salvador (2003-2005) - State Repression and Gang}

\section{Violence under Mano Dura}

Violence and repression shaped the recent history of El Salvador. Between 1980 and 1992, the civil war killed approximately 75,000 people, 85 percent of which died at the hand of state armed forces. Nonetheless, the end of the conflict in 1992 brought optimism to the country. The Chapultepec Peace Accord, negotiated under the auspices of the UN, built bridges between the government of El Salvador, led by the Alianza Nacionalista Republicana (ARENA), and the guerrilla, the Frente Farabundo Martí para la Liberacion Nacional (FMLN). For the main negotiator Alvaro de Sotto, the UN played a "ground-breaking role in El Salvador, the first case of the UN mediating the resolution of internal conflict between a government and an insurgent group, [where institutional reforms would outlast] initial stages of demobilisation of the insurgent army and the profound reforms and reduction of the armed forces and their subordination to the civilian authority." 416 The peace process prevented the relapse of the conflict and allowed for the integration of the guerrilla in the political life of the country. By the end of the 1990s, foreign commenters and experts considered the peace process in El Salvador and especially the police and military reforms as a clear success. ${ }^{417}$

\footnotetext{
${ }^{416}$ de Soto, "Foreword," xviii.

${ }^{417}$ See, for example, William Stanley, "Building New Police Forces in El Salvador and Guatemala: Learning and Counter-learning," International Peacekeeping 6, no. 4 (1999): 113-34, doi:10.1080/13533319908413801; Gino Costa, "The United Nations and Reform of the Police in El Salvador," International Peacekeeping 2, no. 3 (1995): 365-90, doi:10.1080/13533319508413567; Tommie Sue Montgomery, "Getting to Peace in El Salvador: The Roles of the United Nations Secretariat and ONUSAL," Journal of Interamerican Studies and World Affairs 37, no. 4 (December 1, 1995): 13972, doi:10.2307/166249.
} 
Yet, rising concerns for public security, crime, and violence quickly replaced the popular optimism that had characterized the direct aftermath of the war. ${ }^{418}$ From the mid1990s, graphic coverage of violent crime by the media, the resurgence of death squads, and the increased visibility of criminal gangs such as Mara Salvatrucha (MS-13) and Barrio 18 (La18) contributed to make security and crime the primary concern of the Salvadoran population. Furthermore, homicides skyrocketed in the direct aftermath of the war, reaching 139.1 homicides per 100,000 people in $1995 .{ }^{419}$ Numbers then started to decline, coincidentally with the deployment of the Policía Nacional Civil (PNC) across the country. Murders actually dropped by more than 50 percent between 1995 and 2000 . Nevertheless, despite those encouraging trends, homicide numbers remained extremely high, stalling at a level representing approximately five times the World Health Organization's (WHO) "epidemic" threshold. ${ }^{420}$ Indeed, while the conflict killed approximately 75,000 people, over 80,000 people died violently between 1992 and $2016 .^{421}$ For many Salvadorans, peace became worst than the war. ${ }^{422}$

\footnotetext{
${ }^{418}$ José Miguel Cruz, “The Peace Accords Ten Years Later: A Citizen's Perspective," in El Salvador's Democratic Transition Ten Years After the Peace Accord, ed. Cynthia Arnson (Washington, D.C.: Woodrow Wilson International Center for Scholar, 2003).

${ }^{419}$ Charles T. Call, "The Mugging of a Success Story: Justice and Security Reform in El Salvador," in Constructing Justice and Security after War, ed. Charles T. Call (Washington, DC: US Institute of Peace Press, 2007), 38; Cruz, "Violence, Citizen Insecurity, and Elite Maneuvering in El Salvador," 152. ${ }^{420}$ The World Health Organization considers a rate of 10 per 100,000 population as an epidemic. See Christine Wade, "El Salvador's Murder Epidemic and the Paradox of Peacebuilding Success," World Politics Review, January 25, 2016, http://www.worldpoliticsreview.com/articles/17762/el-salvador-smurder-epidemic-and-the-paradox-of-peacebuilding-success.

${ }^{421}$ The IUDOP estimates that 73,000 people were killed in El Salvador between 1992 and 2014. When we add the PNC homicide numbers for 2015 and 2016, the number of violent deaths since the end of the war goes beyond 80,000. See IUDOP, "La Situación de La Seguridad Y La Justicia 2009-2014: Entre Expectativas de Cambio, Mano Dura Militar Y Treguas Pandilleras," xix.

${ }^{422}$ In her book, Ellen Moodie explores the transformation of violence through narratives of daily life events and their implications for the democratization of the Salvadoran State. Ellen Moodie, El Salvador in the Aftermath of Peace: Crime, Uncertainty, and the Transition to Democracy, The Ethnography of Political Violence (Philadelphia: University of Pennsylvania Press, 2010).
} 
Hence, despite significant reforms in the security and justice sector, the state security apparatus showed unable to address sufficiently crime and violence in order to make Salvadorans feel safer. As Charles T. Call points out, "the crime wave underlies the most interesting paradox of El Salvador's police and justice reforms: international observers consider them as a success story, but Salvadorans do not." ${ }^{\text {"423 }}$ Indeed, contrary to the diagnostic posed by several experts in the late 1990s, the reform of the security institutions did not enable the Salvadoran State to re-establish its monopoly over the use of coercive force. Such a monopoly would have produced a high level of public order, and kept violence and crime relatively low. Instead, El Salvador continues to be characterized by a pluralist POR where non-state coercive actors manage to claim significant control over the means of violence and state institutions still rely to a certain extent on informal means to produce public order.

In the next two chapters, I look at the long-term consequences of incomplete post-war SSR in El Salvador. I argue that these reforms failed to acknowledge the transformation of the POR in the post-war years, and to address effectively informal public ordering by non-state coercive actors. More specifically, the State mostly ignored local gangs, thereafter called cliques, in peripheral communities. However, media increasingly portrayed local cliques as a public security issue. The gangs progressively became the ideal scapegoat to call on harsher security measures: they were mostly concentrated in marginalised areas and could easily be portrayed as dangerous criminals threatening law-

${ }^{423}$ Call, “The Mugging of a Success Story: Justice and Security Reform in El Salvador," 23. 
obeying, hard-working Salvadorans. ${ }^{424}$ By the early 2000s, gangs were painted in popular imagination as the main threat to El Salvador's security and stability.

In this chapter, I look at the consequences of Mano Dura policies (2003-2005) on the level of public order in El Salvador. In July 2003, President Flores announced the Mano Dura (Iron Fist) strategy. The State promised to hit hard on gangs and reclaim control over communities submitted to their yoke. In other words, Flores proposed to use police and military forces to expand state authority and eliminate non-state coercive actors with competing claims over the means of violence who were perceived as being highly disruptive. Mano Dura sought to reduce drastically crime and violence in time for the 2004 presidential elections. However, the plan backfired. From 2002 (47.3 homicides per 100,000 population) to 2005 (64.7 homicides per 100,000 population), the national homicide rate increased sharply.

I argue that despite attempts at expanding state authority under Mano Dura following incomplete SSR, the State was unable to eliminate competing coercive actors mostly due to a dysfunctional criminal justice system. In response, the gang locus switched from the local to the national level, and violence increased as local cliques expanded their territorial claims and intensified their extortion activities. State and non-state informal public ordering increased, as frustration from PNC officers and inside the Salvadoran population translated into extrajudicial violence.

I first discuss briefly public order during the civil war, the Chapultepec Peace Accords, and the reform of security institutions that followed. Second, I map out the pluralist POR that was shaped by the peace process and came to characterised El

\footnotetext{
${ }^{424}$ USAID, "USAID Central American and Mexico Gang Assessment” (USAID, April 2006), 49-50,
} http://pdf.usaid.gov/pdf_docs/Pnadg834.pdf. 
Salvador prior to Mano Dura. Third, I discuss how Mano Dura sought to expand state authority over the POR. Fourth, I turn to the distributive implications of Mano Dura and its disruptive consequences on public order, illustrated by higher levels of violence and a lesser level of public order. In the end, the resulting POR was less functional and more violent, a direct consequence of an ill-adapted state expansion strategy under Mano Dura.

\subsection{The Chapultepec Peace Accords and Post-war SSR}

\subsubsection{Wartime order}

Any civil war implies the breakdown of the State's monopoly on the use of coercive force, and the open contestation of state authority through violent means by organized armed groups. As a result, wartime PORs are pluralist. The situation was not different during the Salvadoran civil war. In El Salvador, the FMLN had managed to gain control over part of the national territory and implement local governance structures, providing services to the population in exchange for their support. ${ }^{425}$

In response, the State relied on both formal and informal means to oppose the guerrilla. The Salvadoran armed forces and their specialized battalions were involved in the massacre and torture of civilians. ${ }^{426}$ Non-state armed groups also formed to fight the communist rebellion. ${ }^{427}$ Often referred to as death squads, these groups were originally

\footnotetext{
${ }^{425}$ Wood, Insurgent Collective Action and Civil War in El Salvador; Mampilly, Rebel Rulers.

${ }^{426}$ The civil war in El Salvador was punctuated by the killing of prominent social activists and religious figures, including the Archbishop Oscar Arnulfo Romero on March 1980 and six Jesuit priest on the campus of the Universidad Centroamericana "José Simeón Cañas" in 1989. The armed forces and their specialised counter-insurgency battalions also massacred villages in search for intelligence on the FMLN and in reprisal for supporting the guerrilla movement. See, for example, Call, "Democratisation, War and State-Building," 831; William Stanley, The Protection Racket State: Elite Politics, Military Extortion, and Civil War in El Salvador (Philadelphia: Temple University Press, 1996); Mark Danner, The Massacre at El Mozote, 1 edition (New York: Vintage, 1994).

${ }^{427}$ UN Security Council, "From Madness to Hope: The 12-Year War in El Salvador: Report of the Commission on the Truth for El Salvador" (United Nations, 1993), 163, http://www.usip.org/sites/default/files/file/ElSalvador-Report.pdf.
} 
civilian organisations independent from the State in regard to their structure, funding, and control. However, police and military serving officers "gradually seized control of the death squads for personal gain or to promote certain ideological or political objectives." 428 While some death squads remained independent from the State, statelinked groups operated mostly out of the police forces and the intelligence services. ${ }^{429}$ Hence, a complex constellation of actors characterized El Salvador during the civil war.

\subsubsection{The Chapultepec Peace Accords}

The overall objective of the peace agreement was "to end the armed conflict by political means as speedily as possible, promote the democratization of the country, guarantee unrestricted respect for human rights and reunify Salvadorian society."430 During the peace negotiations, the reform of the armed forces and the creation of a new independent civilian police force became the basis on which the Chapultepec Peace Accords would be established. The vast majority of the killings had occurred at the hands of the security forces or state-sponsored groups. As a matter of fact, the Commission on the Truth for El Salvador received more than 22,000 complaints regarding acts of violence committed against civilians during the war. ${ }^{431}$ According to its report, "armed forces personnel were accused in almost 60 per cent of complaints, members of the security forces in approximately 25 per cent, members of military escorts and civil defence units in approximately 20 per cent, and members of the death squads in more

\footnotetext{
428 Ibid.

${ }^{429}$ Ibid.

${ }^{430}$ Government of El Salvador and Frente Farabundo Martí para la Liberacíon Nacional, "El Salvador Peace Agreement (Chapultepec)" (Mexico, January 16, 1992), http://peacemaker.un.org/elsalvadorchapultepec92.

${ }^{431}$ Provided by the peace accords, The Truth Commission, composed of Belisario Betancur (chairman), Reinaldo Figueredo Planchart, and Thomas Buergenthal, was mandated to investigate "serious acts of violence that have occurred since 1980 and whose impact on society urgently demands that the public should know the truth." Ibid.
} 
than 10 per cent of cases. The complaints registered accused FMLN in approximately 5 per cent of cases." 432 The objective of the reforms was therefore to make sure that the conditions that had allowed such violations would be eliminated.

The peace also depended on the demobilisation of FMLN fighters and the integration of the guerrilla movement in the country's political system. Consequently, the FMLN became a political party, and some of its former combatants join the new police force. However, the early withdrawal of the FMLN fighters created authority gaps in many communities, ${ }^{433}$ offering significant opportunity for the emergence of new coercive actors where the State was still not projecting its authority and producing public order in a constant manner.

\subsubsection{Security sector reform}

El Salvador reformed its security institutions well before the elaboration of the SSR concept. Nonetheless, its reform process shares key similarities with the SSR framework as currently understood. It targeted the entire state security system and was coordinated at least in part with DDR efforts. These reforms also constituted the first explicit efforts in the post-cold Cold War era to transform security provision along principles of good governance, accountability, and local ownership, beyond traditional train-and-equip programs. While national actors mainly led reforms, the UN Observers Mission to El Salvador (ONUSAL) and bilateral partners supported the reform process through training and monitoring activities between 1992 and $1995 .{ }^{434}$

\footnotetext{
${ }^{432}$ UN Security Council, "From Madness to Hope: The 12-Year War in El Salvador: Report of the Commission on the Truth for El Salvador."

${ }^{433}$ Wood, "The Social Processes of Civil War."

${ }^{434}$ Costa, "The United Nations and Reform of the Police in El Salvador."
} 
Prior to the conflict, the armed force benefited from a privileged position giving them access to important resources in exchange for support and protection of national elites. By the end of the war, they could count on 60,000 personnel. ${ }^{435}$ The three existing police forces, the National Police, the Treasury Police, and the National Guard, were under the command of the Ministerio de la Defensa Nacional (Ministry of National Defence MDN). As noted above, they were involved in widespread human rights violations during the war. ${ }^{436}$ For its part, the judiciary was highly politicized and there was little distinction between the different branches of government. The Supreme Court of Justice was a powerful institution; its judges were closely associated to ARENA. Combined with the inquisitorial model of the justice system where judges would lead investigations, there was little place for fair, transparent, and evidence-based justice. ${ }^{437}$

Following the adoption of a new constitution derived from the peace agreement, the role of the military forces in domestic matters was significantly reduced. The institution was put under civilian oversight in order to promote transparency, democracy, and respect for human rights. Troop levels were also reduced by half (from 60,000 in 1992 to 28,800 in 2000) to fit the new mandate of the institution, "to defend the sovereignty of

\footnotetext{
${ }^{435}$ World Bank, “Armed Forces Personnel, Total I Data I Table,” World Development Indicators, 2015, http://data.worldbank.org/indicator/MS.MIL.TOTL.P1?page=3.

${ }^{436}$ Call, "Democratisation, War and State-Building"; Costa, "The United Nations and Reform of the Police in El Salvador."

${ }^{437}$ For a detailed discussion of the Salvadoran justice system, its reform, and its many challenges, see Margaret Popkin, Peace without Justice: Obstacles to Building the Rule Oflaw in El Salvador (University Park, Pa: Pennsylvania State University Press, 2000); Margaret Popkin, "Building the Rule of Law in PostWar El Salvador," in EL Salvador: Implementation of the Peace Accords, ed. Margarita S. Studemeister (Washington, D.C.: United States Institute of Peace, 2001), 10-19.
} 
the State and the integrity of its territory," and ensure its subordination to civilian political order and democratic principles. ${ }^{438}$

In parallel, a new independent civilian police force dedicated to public security was created to counter-balance the armed forces in the state security apparatus. The peace negotiation limited the number of former members of the armed forces and the guerrilla could who could join the new police service. Each group could make up only 20 percent of the PNC, ensuring that 60 percent of the new police force was composed of new recruits. An independent police academy, the Academia Nacional de Seguridad Pública (National Academy of Public Security - ANSP), was also put in place to ensure the training and the long-term professionalization of the police force. While the institutional transition was slower than expected in the years following the peace agreement, the PNC was deployed across the country in 1995. By 1999, the ANSP had trained 16,000 police officers, and the formation was entirely provided by Salvadoran instructors. ${ }^{439}$

The peace accord also included limited reforms in the justice sector, but there was significantly less appetite among political elites for a profound transformation of the justice system. ${ }^{440}$ Nonetheless, the Consejo Nacional de Justicia, in charge of nominating judges, was reinforced and given more autonomy, while the Supreme Court was progressively depoliticized. The new constitution also guaranteed funding to the judicial system to ensure its independence. ${ }^{441}$ Finally the nomination process for key positions in

\footnotetext{
${ }^{438}$ World Bank, “Armed Forces Personnel, Total I Data I Table”; Government of El Salvador and Frente Farabundo Martí para la Liberacíon Nacional, "El Salvador Peace Agreement (Chapultepec).”

${ }^{439}$ Stanley, "Building New Police Forces in El Salvador and Guatemala," 117.

${ }^{440}$ For a detailed discussion of early justice reform and its shortcomings, see Popkin, Peace without Justice.

${ }^{441}$ Charles T. Call, “Assessing El Salvador's Transition from Civil War to Peace," in Ending Civil Wars:

The Implementation of Peace Agreements, ed. Stephen J. Stedman, Donald S. Rothchild, and Elizabeth

Cousens (Boulder: Lynne Rienner Publishers, 2002), 554.
} 
the judicial sector was submitted to a two-thirds majority vote from the legislative assembly. $^{442}$

In sum, the reform of the security and justice sectors in El Salvador focused principally on the structure of the different institutions, their prerogatives, and their mandate. The objective was to re-establish the State's monopoly over the production of public order in accordance with good governance principles. It was assumed that, in combination to the end of the civil war, the process would establish a monist POR. However, there was little discussion of how the state institutions would adapt and respond to a rapidly changing domestic security context. The POR in the direct aftermath of the conflict presented some important challenges for SSR and public order more broadly. While the reforms included in the peace accords tackled some of the key problems that explained conflict outbreak, duration, and intensity, they did not foresee the consequences of the war and its end on the structure of the POR. Beyond the creation of a transitional police force from 1992 to 1995 , little attention was given to the fact that the security gap created by the DDR and SSR processes could actually create conditions conductive to the emerge of new coercive actors within the POR.

\subsection{The post-war Salvadoran public order regime}

There is strong evidence suggesting that the Salvadoran POR (table 5) remained pluralist despite formalisation efforts under SSR. Through the 1990s, the composition of the POR evolved. Some coercive actors repositioned themselves while other emerged or progressively disappeared. The State did not managed to re-establish its monopoly on the use of coercive force, notwithstanding the disbandment of the FMLN and the creation of

${ }^{442}$ Popkin, "Building the Rule of Law in Post-War El Salvador," 15. 
the PNC. Gangs progressively gained in importance and influence in peripheral communities where the State did not provide a sufficient level of public order. Furthermore, Salvadorans who felt unsafe and had the means to do so turned to private security firms for protection. Hence, multiple coercive actors continued to produce public order in post-conflict El Salvador.

Table 5 The post-war Salvadoran public order regime, 1992-2002

\begin{tabular}{|l|l|l|}
\hline & Informal Public Ordering & Formal Public Ordering \\
\hline Non-state Actors & Gangs & Private security firms \\
\hline State Actors & Death squads & $\begin{array}{l}\text { Police forces } \\
\text { Armed forces } \\
\text { Intelligence services } \\
\text { Justice system }\end{array}$ \\
\hline
\end{tabular}

\subsubsection{State public ordering}

\subsubsection{Formal public ordering}

The objective of SSR in El Salvador was to put in check the military and develop an approach to security and justice oriented towards service provision in a transparent and accountable manner respectful of human rights. With regard to the police forces, the PNC could count on approximately 16,000 police agents deployed throughout the country by 2000. ${ }^{443}$ There were approximately 255 police personnel per 100,000 population in El

${ }^{443}$ UNODC, “The Eighth United Nations Survey on Crime Trends and the Operations of Criminal Justice Systems (2001 - 2002)" (UNODC, March 31, 2005), https://www.unodc.org/unodc/en/data-andanalysis/Eighth-United-Nations-Survey-on-Crime-Trends-and-the-Operations-of-Criminal-JusticeSystems.html. 
Salvador in 2001-2002. ${ }^{444}$ High crime rates and public perception of insecurity had incentivised the Sol Calderon administration (1994-1999) to focus on the deployment and the development of police personnel across the country. ${ }^{445}$ Popular demands for swift results led to a prioritization of the PNC's quantitative needs to the detriment of qualitative considerations. Little attention was given to internal control mechanisms, criminal investigations capacities, and institutional development planning ${ }^{446}$ If the initial objective of the reform process was to create a community-oriented police service in white shirts and kepis, PNC officers wore black uniforms and combat boots by $2000 .{ }^{447}$

The emphasis on numbers and the pressure to address insecurity undermined the fight against impunity that was central to the peace process and the reform of the security and justice institutions. First, elements suspected of wartime crimes managed to remain in position in the military force, or were incorporated in the new police service. In its report, the UN-supervised Truth Commission named members of the armed forces, the judiciary, and the public service who were involved in the perpetration or the cover-up of serious acts of violence during the war. The Commission recommended their immediate dismissal and barred their future participation in "any activity related to public security and national defence." ${ }^{\$ 48}$ The report also recommended significant judicial reforms before undertaking any prosecution for war crimes and the immediate removal of the entire

\footnotetext{
${ }^{444}$ Ibid.

${ }^{445}$ Cruz, "The Peace Accords Ten Years Later: A Citizen's Perspective."

${ }^{446}$ Edgardo Alberto Amaya, "Security Policies in El Salvador, 1992-2002," in Public Security and Police Reform in the Americas, ed. John Bailey and Lucía Dammert (Pittsburg: University of Pittsburgh Press, 2006).

${ }^{447}$ Interview with the director of the ANSP, San Salvador, July 2013.

${ }^{448}$ UN Security Council, "From Madness to Hope: The 12-Year War in El Salvador: Report of the Commission on the Truth for El Salvador," 166.
} 
Supreme Court. ${ }^{449}$ The ARENA government, led by Alfredo Cristiani, reacted negatively and swiftly. Less than a week after the presentation of the Truth Commission's report, the legislative assembly adopted an amnesty law preventing the prosecution of any military officer other than those who had already been purged by a national ad hoc commission. ${ }^{450}$ As a result, members of the security forces who had directly participated or ordered the perpetration of war crimes remained in position and were never prosecuted.

Second, pressure for results led to the integration in the new police service of elements of the disbanded security force without proper vetting. The entire Unidad Ejecutiva Antinarcotráfico (anti-narcotic unit - UEA) and special investigation teams from the disbanded police forces were directly transferred to the PNC, without going through the vetting and training channels put in place following the peace accords. Their members were only vetted after important pressure from ONUSAL, but no measures were taken against officers from those units who had been involved in human rights violations during the war. ${ }^{451}$ Furthermore, with the support of President Cristiani and the United States, the armed forces pushed for the appointment of military officers in key positions inside the PNC. For instance, the first Deputy Director of Operations was an army captain with experience in anti-narcotics. While his experience helped structure and organise the PNC in its early days, "he contributed to undermining the new civilian police doctrine and impose a military code of discipline. [...] The most serious threat to the new police force, however, was his attempt to command and control it through UEA

\footnotetext{
${ }^{449}$ Ibid., 167.

${ }^{450}$ El Salvador, "General Amnesty Law for the Consolidation of Peace," Pub. L. No. Legislative Decree 486 (1993); Popkin, "Building the Rule of Law in Post-War El Salvador," 11.

${ }^{451}$ Costa, "The United Nations and Reform of the Police in El Salvador."
} 
military personnel who had been transferred irregularly into the PNC." 452 Those elements were later accused of contributing to political bias, favouritism, and corruption inside the police force. Indeed, members of the UEA and the special investigation unit were promoted illegally once they joined the PNC, despite the fact that they did not meet the requirements. ${ }^{453}$ These irregular transfers affected the PNC's commanding structure. By 2002, it became evident that the promotion system favoured former military officers. Of 18 commissioners, eight were former members of the armed forces, six were civilians, and four originated from the FMLN. ${ }^{454}$

Third, concerns for a swift reduction in violent crime after 1995 undermined the prospect for judicial reforms. Early on, members of the executive branch resisted to a deep transformation of the Salvadoran justice system. Following the adoption of new criminal, procedural, and sentencing codes in 1998, the then Minister of Public Security, Hugo Barrera, stated that the new codes were "the principal security problem as they [gave] exaggerated protection to criminals. ${ }^{, 455}$ In other words, guarantee of due process was perceived as a threat to security. Resistance to judicial reforms also undermined the independence of judges. A 2002 survey conducted by the Red Centroamericana de Jueces, Fiscales y Defensores por la Democratizacion de la Justicia revealed that 60.8 percent of the surveyed judges felt subject at least somewhat to pressure from the executive branch. ${ }^{456}$ Political influence over the judiciary affected the interpretation and

452 Ibid., 373.

${ }^{453}$ Ibid.

${ }^{454}$ Call, "Democratisation, War and State-Building," 838-39.

${ }^{455}$ Popkin, "Building the Rule of Law in Post-War El Salvador," 17.

${ }^{456}$ FESPAD, CEPES, and Red Centroamericana de Jueces, Fiscales y Defensores por la Democratizacionde la Justicia, "Informe Para La Audiencia Sobre La Independencia Judicial En Centroamerica" (report prepared for the Inter-American Commission on Human Rights, 2004), 7. 
the application of the law, witness protection measures, and judges' immunity from criminal prosecution. ${ }^{457}$

Overall, right wing political elites and decision-makers perceived SSR as an actual threat to the safeguard of public order and security. As a result of that resistance, and in combination to shortcomings in the development of the PNC, SSR did not manage to completely reform the state security and justice apparatus. These shortcomings led experts to argue that El Salvador is a prime example of how formal institutional reforms do not necessarily lead to change in culture and practices. ${ }^{458}$ Interestingly enough, despite the government's announced efforts toward violence and crime control, the security and justice sector remained unable to deal adequately with offenders. Through the 1990s, less than 10 percent of homicides actually led to conviction and prosecution. ${ }^{459}$ Impunity demonstrates the incapacity of the State to produce a sufficient level of public order to deal adequately with crime, despite a reduction in homicides (see figure 1).

\subsubsection{Informal public ordering}

Partial reforms of the armed forces, the police, and the justice system prevented a complete formalization of state public ordering. Resistance early on to fight impunity and improve transparency, as well as complacency towards human rights violations permitted the persistence of informal public ordering by state actors. ${ }^{460}$ The participation of

\footnotetext{
${ }^{457}$ Laura Pedraza Fariña, Spring Miller, and James Cavallaro, No Place to Hide: Gang, State, and Clandestine Violence in El Salvador, Human Rights Program Practice Series (Cambridge, Mass: Harvard University Press, 2010), 19-20.

${ }^{458}$ Call, "Democratisation, War and State-Building."

${ }^{459}$ Edgardo A. Amaya Cóbar, "Quince Años De Reforma Policial En El Salvador : Avances Y Desafíos," Urvio, Revista Latinoamericana de Seguridad Publica, no. 2 (2007): 132.

${ }^{460}$ The absence of and resistance to a reconciliation process contributed to the perpetuation of impunity in the post-war years. Interview with a program coordinator for second-chance project, Catholic Relief Services, San Salvador, May 2015.
} 
members of the security forces to death squads and cleansing groups, as well as extrajudicial violence perpetrated by state officials embodied state informal public ordering through the 1990s.

Evidence suggests that state-linked death squads continued to conduct political assassinations in relative impunity in the post-war years. In December 1993, President Cristiani authorised the creation of a joint commission sponsored by the UNDP to investigate the persistence of death squads with political motives. Looking at a series of incidents following the end of conflict, the report concluded that while police officers and other members of the state security apparatus participated in death squads' activities, the government was not actively involved. ${ }^{461}$ It also included a confidential annex, listing members of the state security forces involved in death squads' activities. During the press conference following the publication of the report, Diego García Sayán, a member of the joint commission and the director of ONUSAL's Human Rights Divisions, stressed that the structures of the death squads in post-war years were different than those active during the civil war. ${ }^{462}$ These new groups adopted operational patterns similar to organised and ordinary crime.

Despite the work of the joint commission, death squads continued to be active in the second half of the 1990s. In 1996, Amnesty International published a report denouncing the re-emergence of death squads driven by political and social motives. ${ }^{463}$ For Jaime Martinez, current director of the ANSP, death squads' motivation mutated from war-time

\footnotetext{
${ }^{461}$ AP-Reuter, "Informe Sobre Escuadrones de La Muerte En El Salvador," Eltiempo.com, July 29, 1994, http://www.eltiempo.com/archivo/documento/MAM-183566.

${ }^{462}$ Ibid.

${ }^{463}$ Amnesty International, "El Salvador: The Spectre of Death Squads" (Amnesty International, December 1996).
} 
political objectives to social cleansing motives. Yet, post-war death squads were also involved in the assassination of former leaders of the guerrilla. ${ }^{464}$

The most famous case is probably the Sombra Negra (Black Shadow) which murdered 21 people in the city of San Miguel in 1994 and 1995, including both gang members and political opponents. Members included local businessmen, PNC officers, and the head of the PNC delegation for San Miguel, César Valdemar Flores Murillo. While their arrest was widely publicized, they were found not guilty due to a lack of evidence. The prosecutors on the case received death threats prior to and during the trial, and the police agent who acted as the whistleblower had to flee the country. ${ }^{465}$ Actually, several informants told me that whistleblowers inside the PNC who denounced illegal practices and abuses were often forced to leave the country. In contrast, César Valdemar Flores Murillo became the Deputy Director General of the PNC in January $2016 .{ }^{466}$

Besides, despite the reform process and the creation of PNC, on-duty members of the security apparatus remained involved in human rights violations and extrajudicial violence throughout the 1990s. According to a $2000 \mathrm{UN}$ report, "[the PNC] never succeeded in establishing themselves as guarantors of transparent police procedures nor of the application of appropriate discipline." ${ }^{467}$ The same year, the PNC undertook successive purges following a series of severe incidents (kidnappings, crime rackets, and extrajudicial killings) involving police officers. The legislature, which comprised for the

\footnotetext{
${ }^{464}$ Interview with the director of the ANSP, Santa Tecla, July 2013.

${ }^{465}$ Lawrence Michael Ladutke, "Expression for and against the Vigilante Death Squad Sombra Negra," Southwestern Journal of Law and Trade in the Americas 8 (2002 2001): 283; Amnesty International, "El Salvador: The Spectre of Death Squads."

${ }^{466}$ elsalvador.com, “¿Quiénes Son Los Nuevos Funcionarios de Gobierno?,” Http://Www.elsalvador.com/, January 22, 2016, http://www.elsalvador.com/articulo/nacional/quienes-son-los-nuevos-funcionariosgobierno-99428.

${ }^{467}$ Report cited by Charles T. Call (2003).
} 
first time a significant number of representatives from the FMLN following the 1998 legislative elections, granted special powers to the PNC director and a presidential commission was created. The commission enquiry led to the removal of 1,215 police officers, in addition to 1,485 officers through regular internal mechanisms, less than a decade after the creation of the PNC. ${ }^{468}$ Hence, while the PNC could count on an effective of approximately 16,000 in 2000 , the purge led to the removal of 2,700 agents, almost 17 percent of the PNC personnel.

All in all, while the reform process managed to create a new civilian police force of significant strength and reduce the role of the military in public security, SSR did not completely formalize state public ordering. While the State gained relative weight inside the POR in the post-war years with the integration of the FMLN in the government, its control over the means of violence did not expand to a monopoly of formal state public ordering.

\subsubsection{Non-state public ordering}

Two key non-state actors shaped the post-war Salvadoran POR. On the one hand, street gangs gained power and influence in the 1990s in low-income urban communities. On the other hand, private security companies grew in size through the decade, responding to the demand for security of wealthy Salvadorans who felt poorly protected by state security institutions.

\subsubsection{Street gangs}

${ }^{468}$ Call, "Democratisation, War and State-Building," 844. 
Street gangs have existed in El Salvador for decades. Experts traced their origins back to the $1960 \mathrm{~s} .{ }^{469}$ During the war, gangs corresponded to small groups of teenagers in San Salvador' lower-class neighbourhoods and other urban centers who controlled their turf through the use of violence. ${ }^{470}$ On the one hand, the war had undermined local mechanisms of governance, ${ }^{411}$ creating space for local cliques to form and progressively establish turfs they could control. On the other hand, according to Thomas Bruneau, "these gangs were contained through the same mechanisms that the authoritarian regime used to suppress political dissent and disorder: intense, often violent, repression.."472

Once the war was over, the momentary security vacuum created by the demobilisation of FMLN fighters, the reform of the state security forces, and the lack of economic opportunity offered favourable conditions for gang proliferation. The National Guard and the Treasury Police were immediately demobilised and the military forces were confined to their barracks under UN supervision. Only the 6,000 members of National Police remained to patrol the country, supervised by ONUSAL. ${ }^{473}$ According to Gino Costa, former political advisor to the chief of ONUSAL, "many organized gangs appeared in the cities and the country-side, becoming the chief source of public insecurity. Despite government rhetoric, little was done to tackle them, because in the effort to create the new police force, the immediate creation of expert detective units was

\footnotetext{
${ }^{469}$ Wolf, "Street Gangs of El Salvador"; Cruz, "Global Gangs in El Salvador: Maras and the Politics of Violence," 3.

${ }^{470}$ José Miguel Cruz, Street Gangs in El Salvador, UCA Editores (San Salvador, El Salvador, 2007), 1319; cited by Thomas C. Bruneau, "Pandillas and Security in Central America," Latin American Research Review 49, no. 2 (2014): 156, doi:10.1353/lar.2014.0022.

${ }^{471}$ See Wood, "The Social Processes of Civil War."

${ }^{472}$ Bruneau, "Pandillas and Security in Central America," 157.

${ }^{473}$ Stanley, "Building New Police Forces in El Salvador and Guatemala," 118.
} 
not given its due." ${ }^{474} \mathrm{He}$ adds: "a high number of demobilized soldiers, policemen, and combatants swell the ranks of the unemployed and maladapted, increasing unrest and insecurity." ${ }^{475}$ Early studies ${ }^{476}$ on Salvadoran street gangs focus primarily on socioeconomic conditions that contributed to the popularity of the gangs in low-income neighbourhoods, as well as the kind of illegal activities they engaged in: "gang members spent much of their time hanging out, partying and taking drugs, fighting their rivals, and committing robberies." ${ }^{, 47}$

Street gangs, often referred to as maras, ${ }^{478}$ became a public security phenomenon in the second half of the 1990s. After 1995, increased attention in mass media changed the focus towards their role in crime and violence. Graphic media coverage of violence crime and emphasis on the case of specific gang members who had usually committed

${ }^{474}$ Gino Costa, "Demilitarizing Public Security: Lessons from El Salvador," in EL Salvador: Implementation of the Peace Accords, ed. Margarita S. Studemeister (Washington, D.C.: United States Institute of Peace, 2001), 24.

475 Ibid.

${ }^{476}$ Gang started to attract researchers' attention in the late 1990s, mostly through a research program at the Universidad Centroamericana (UCA) based in the country's capital. Marcela Smutt and Lisette Jenny Miranda's study on gangs in El Salvador is often referred to as the first research on the topic. Marcela Smutt and Jenny Lisette Miranda, El Fénomeno de Las Pandillas En El Salvador (San Salvador, El Salvador: UNICEF-FLACSO, 1998); José Miguel Cruz, "Pandillas Y Capital Social," in Estudios Centroamericanos (San Salvador, El Salvador: Universidad Centroamericana, 2001), 1099-1118; José Miguel Cruz and Nelson Portillo, Solidaridad Y Violencia En Pas Pandillas Del Gran San Salvador: Mas Alla de La Vida Loca (San Salvador, El Salvador: UCA Editores, 1998); Sandra Argueta et al., “Diagnostico Sobre Los Grupos Llamados 'Maras' En San Salvador: Factores Psicosociales Que Prevalecen En Los Jovenes Que Los Integran"” (Bachelor's thesis, Universidad Centroamericana "José Simeon Canas" de El Salvador, 1991).

${ }^{477}$ Wolf, "Street Gangs of El Salvador," 44-45; Argueta et al., "Diagnostico Sobre Los Grupos Llamados 'Maras' En San Salvador: Factores Psicosociales Que Prevalecen En Los Jovenes Que Los Integran"."

478 "Clique", "pandilla," and "mara" are all terms used to describe street gangs in El Salvador. While the meaning of those terms varies across time and space, "clique" usually refers to a small group who is affiliated to a larger organisation, but who remains associated to a specific turf. A clique can control a block, a neighbourhood, or a community, for instance. "Pandilla" is a general term used in Spanish to refer to a gang. A "pandillero" is a gang member. Finally, the meaning and connotation of "mara" varies a lot, although it usually refers directly to the MS-13 (La Mara Salvatrucha) and La18 over other gangs. At the time of my fieldwork, "mara" had a negative connotation and gang members themselves would use the term in a pejorative way. As such, throughout this project, I use "gang" when I refer to the general phenomenon or criminalized young bands, and "clique" when discussing locally based groups claiming control over specific spaces. 
gruesome murders transformed gangs into a threat to public security. ${ }^{479}$ As described by Ellen Moodie, media coverage would present first and foremost the police narrative, focussing on the suspect's offences. ${ }^{480}$ Suspects would be put in front of the cameras, usually hiding their face with their shirt. "Only gang members defied this pattern, glaring at the nation." ${ }^{\circ 81}$

By 2000, the PNC estimated that there were between 10,000 and 20,000 gang members in the country, mostly concentrated in urban zones. ${ }^{482}$ While gangs were mostly arranged as cliques organised around the protection of their local turf, their degree of organisation increased progressively through the decade as different cliques started to affiliate themselves to the MS-13 and La18. ${ }^{483}$ The increasing prevalence of the MS-13 and La18 in El Salvador was directly linked to change in U.S. immigration policies after 1995. Salvadorans who had fled the war created the MS-13 in Los Angeles in the early 1980s. Later on, the gang allied itself with the Mexican Mafia prison gang who controlled cross-border drug trade. La18 was also born in the streets of Los Angeles, bringing together Central American migrants. MS-13 and La18 gang became rivals as turf competition for drug distribution intensified in the late $1980 \mathrm{~s} .{ }^{484}$ By the end of the $1990 \mathrm{~s}$, most cliques through El Salvador were loosely associated to one of those gangs or the other.

\footnotetext{
${ }^{479}$ Interview with a local investigative journalist, San Salvador, September 2013.

${ }^{480}$ See introduction chapter in Moodie, El Salvador in the Aftermath of Peace, 1-17.

${ }^{481}$ Ibid., 6.

${ }^{482}$ Cruz, "Pandillas Y Capital Social."

${ }^{483}$ Cruz and Portillo, Solidaridad Y Violencia En Pas Pandillas Del Gran San Salvador: Mas Alla de La Vida Loca, 199.

${ }^{484}$ Bruneau, "Pandillas and Security in Central America," 157.
} 
Three main factors contributed to the increased prevalence of street gangs in El Salvador through the 1990s. First, despite the peace process, politics and security remained mostly driven by and for elites, leaving out most of the population. Peripheral communities won very little from the years of war and the following peace. As a consequence, at the end of the conflict, gangs had an important power of attraction in many communities for unemployed and uneducated youth, offering solidarity, friendship, identity, and prestige. ${ }^{485}$ As gang membership and control over communities expanded, power, social visibility, and access to drugs and money became equally or even more important factors in explaining gang membership and recruitment. ${ }^{486}$

Second, change in U.S. immigration policy contributed to growing gang membership from the mid-1990s. ${ }^{487}$ The armed conflict displaced a million of Salvadorans and 700,000 had migrated to the United States by $1990 .^{488}$ The end of the Cold War and the progressive termination of civil conflicts in Central America changed U.S. foreign policy priorities, with consequences for the superpower's immigration policies. The 1995 Illegal Immigration Reform and Immigrant Responsibility Act extended the definition of aggravated felony to include 28 separate offenses beyond murder, drug, and weapon trafficking. ${ }^{489}$ Furthermore, any alien serving a sentence of more than a year was now

\footnotetext{
${ }^{485}$ Wolf, "Street Gangs of El Salvador"; Maria L. Santacruz Giralt and Alberto Concha-Eastman, Barrios Adentro: La Solaridad Violenta de Las Pandillas (San Salvador, El Salvador: Instituto Universitario de Opinion Publica (UCA), 2001).

${ }^{486}$ Wolf, "Street Gangs of El Salvador"; Cruz, "Global Gangs in El Salvador: Maras and the Politics of Violence."

${ }^{487}$ Wolf, "Street Gangs of El Salvador"; Elana Zilberg, "Fools Banished from the Kingdom: Remapping Geographies of Gang Violence between the Americas (Los Angeles and San Salvador)," American Quarterly 56, no. 3 (September 1, 2004): 759-79.

${ }^{488}$ Moodie, El Salvador in the Aftermath of Peace, 1; USAID, "USAID Central American and Mexico Gang Assessment," 45.

${ }^{489}$ Thale and Falkenburger, "Youth Gangs in Central America. Issues on Human Rights, Effective Policing, and Prevention," 3-4; Nestor Rodríguez and Jacqueline Maria Hagan, "Fractured Families and
} 
subject to deportation after completing their full prison term. Finally, the new definition became retroactive, making legal permanent residents who had completed their prison sentence deportable. From 1996 to 1997, the number of criminal deportees increased from 36,967 to $50,165 .^{490}$ In the case of Salvadoran deportees, 1,491 criminal aliens were sent back to El Salvador in 1997, in comparison to 1034 in 1996, and 956 in 1995. The number of non-criminal deportees also increased, from 944 in 1995 to 1,148 in 1996, and 2,552 in $1997 .{ }^{491}$ From that point forward, a constant flow of deportees arrived at the airport of San Salvador, most of them having very little ties to their country of origin and barely speaking Spanish. While there is no hard evidence to evaluate the number of gangrelated deportees from 1994, there is a general understanding among experts that many of the younger individuals with U.S. criminal records who landed in El Salvador after 1995 had links with Los Angeles' Latino street gangs. ${ }^{492}$ They brought with them gang knowledge, influence, and culture, walking into low-income neighbourhoods on the outskirt of the main cities. In these barrios, local cliques often represented the only or the most visible social structure to belong to. Local Salvadoran gang culture quickly adapted to and assimilated the Californian gang lifestyle. ${ }^{493}$

Third, the government decision in the late 1990s to segregate imprisoned gang members based on their affiliation reinforced the MS-13 and the La18. Douglas Moreno,

Communities: Effects of Immigration Reform in Texas, Mexico, and El Salvador," Latino Studies 2, no. 3 (December 27, 2004): 329-30, doi:10.1057/palgrave.1st.8600094; Nancy Morawetz, "Understanding the Impact of the 1996 Deportation Laws and the Limited Scope of Proposed Reforms," Harvard Law Review 113, no. 8 (2000): 1936-62, doi:10.2307/1342314.

${ }^{490}$ Statistics from the Immigration and Naturalization Office, presented in Margaret Taylor and Alexander Aleinikoff, "Deportation of Criminal Aliens: A Geopolitical Perspective" (Washington, D.C.: Inter-

American Dialogue, June 1998).

491 Ibid.

492 Thale and Falkenburger, "Youth Gangs in Central America. Issues on Human Rights, Effective Policing, and Prevention."

${ }^{493}$ Bruneau, "Pandillas and Security in Central America," 158. 
former director of the prison system under Francisco Flores and vice-minister of public security under Mauricio Funes, acknowledged that prison segregation worsened the gang issue in El Salvador in the late 1990s. ${ }^{494}$ Imprisonment based on affiliation rather than location or level of dangerousness enabled cliques to develop ties that were later maintained outside. Furthermore, prison segregation polarized gangs based on their affiliation: "[before] we could meet together in groups, they proposed to make groups together and do activities together [...] there were killings inside but it wasn't like people could not encounter each other. After the separation of the prisons, [it] consolidated identity for those thousands of people and that consolidation of identity increased that of the other as the enemy."495

These three elements contributed to the increasing prevalence of gangs in El Salvador through the 1990s. By the end of the decade, cliques successfully claimed some control over certain communities and neighbourhoods. Nonetheless, they faced little opposition from the State, despite increasing media coverage.

\subsubsection{Private security firms}

Private security firms grew in importance after the war. While there were only a limited number of private security firms in the direct aftermath of the conflict, the number of companies grew exponentially over 10 years, reaching between 265 and 295 firms in 2001 according to different sources. ${ }^{496}$ The number of private security agents also

\footnotetext{
${ }^{494}$ Interview with Douglas Moreno, Ilopango, September 2013.

${ }^{495}$ Interview with a local researcher, FESPAD/Interpeace, San Salvador, September 2013.

${ }^{496}$ Lucia Dammert, "Seguridad Privada: Repuesta a Las Necesidades de Seguridad Publica En Conglomerados Urbanos?" (Organizacion de los Estados Americanos, March 2008); Licide Michelle Melara Minero, "Los Servicios de Seguridad Privada En El Salvador," Estudios Centroamericanos, no. 636 (October 2001): 907-32.
} 
increased from approximately 6,000 in 1996 to almost 20,000 in $2001 .{ }^{497}$ By the turn of the $21^{\text {st }}$ century, there were actually more private security agents than police officers in the country. In response to that growth, the government adopted legislation in 1996 and 2001 regulating private security activities, including the participation of members of state security forces in their activities. As a commercial service, private security became increasingly popular with the middle and the upper class. From doormen and guards outside residential and commercial complexes to drivers and bodyguards, private security firms provided security for people who were able to pay for their service and felt unprotected by the State.

\subsubsection{Overall level of public order}

Through the 1990s, the Salvadoran POR proved unable to produce a sufficient level of public order to make Salvadorans feel safe. Despite steady reduction in homicide numbers until 2001, the PNC was unable to address the growing popular perception of insecurity.

\footnotetext{
${ }^{497}$ Dammert, "Seguridad Privada: Repuesta a Las Necesidades de Seguridad Publica En Conglomerados
} Urbanos?," 22 . 
Figure 1 National homicide rate, El Salvador, 1992-2008

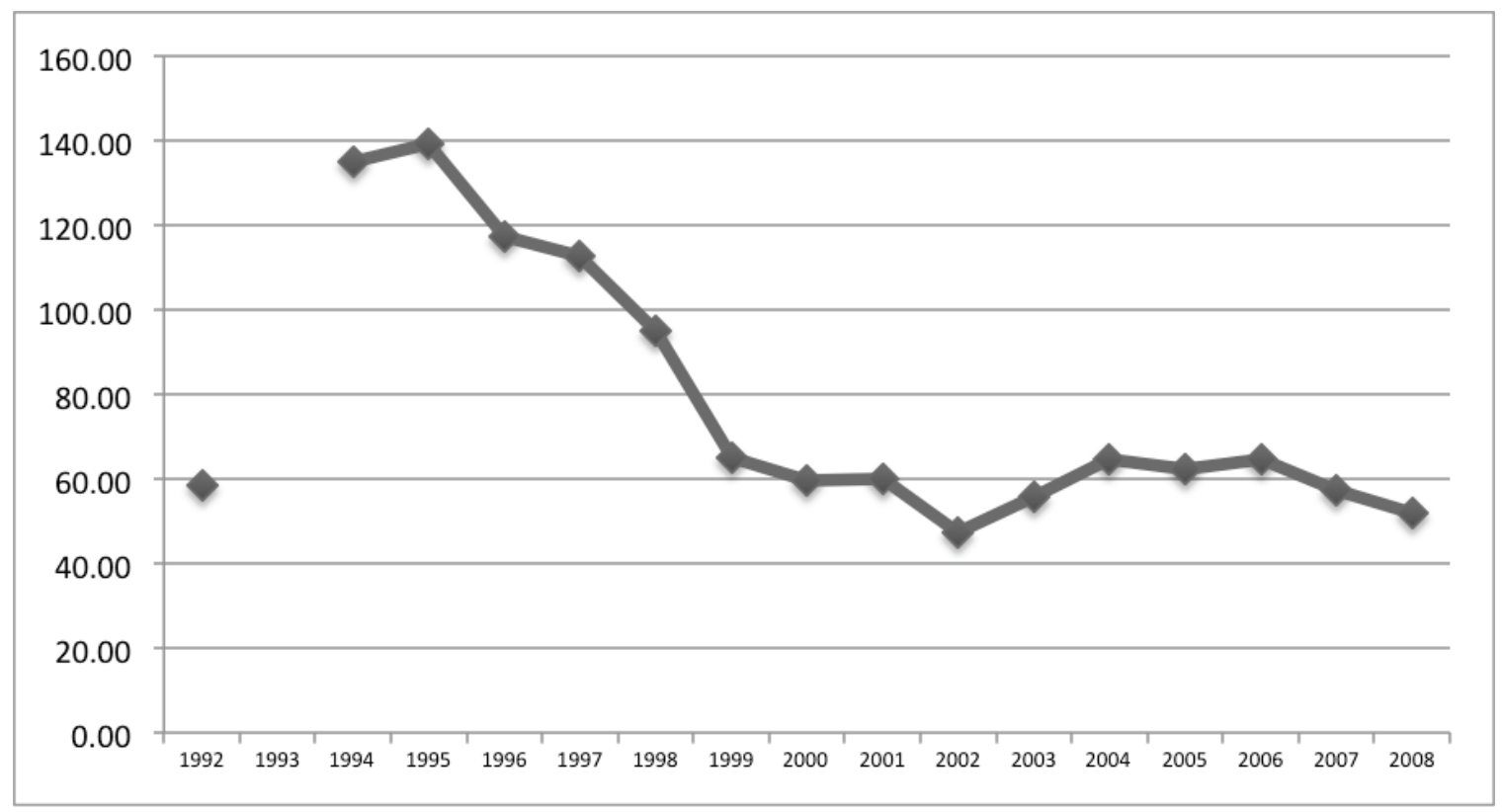

Source: Fiscalía General de la Republica (1992, 1994); Policía Nacional Civil (1995-2008).

There was an important disjunction between the evolution of homicides and how the population perceived public security. Based on data gathered through opinion surveys by the IUDOP, José Miguel Cruz shows that in 1994, 15.7 percent of people surveyed considered that fighting crime should be the priority of the next government. ${ }^{498}$ In 1999 , that percentage had risen to 44.7 percent, well in front of any other issue. ${ }^{499}$ Furthermore, while numbers show a decline in homicides from 1995, more than half of the population surveyed considered that crime was increasing every year between 1996 and 2000. That perception decreased consistently from 1996 (85.0 percent) to 2001 (42.3 percent), there was nonetheless a striking gap between numbers and perception. It is true that homicides do not capture the full spectrum of crime that may have contributed to public perception of insecurity. Nevertheless, data gathered by the IUDOP show that between 1994 and

${ }^{498}$ Cruz, “The Peace Accords Ten Years Later: A Citizen's Perspective,” 30.

${ }^{499}$ The second most important issue in 1999 was "eradicating poverty," with a percentage of 20.7. See Ibid. 
2000 , victimization percentage of those surveyed declined from 39.5 percent to 16.1 percent. ${ }^{500}$ Yet, by 2000, despite the sustainability of the peace and the presence of a new civilian police force with significant strength, Salvadorans felt unsafe. For many people, peace had become worse than war. ${ }^{501}$

Fear and perceived insecurity had important consequences on the best approach to tackle insecurity in the eyes of Salvadorans. In 1996, a public opinion survey revealed that almost half of the respondents considered that "people have the right to take justice in their own hands because the government does not provide security and justice. ${ }^{, 502}$ The inability of the State's security institutions to deal with high levels of crime and violence led to calls from the electorate for repressive and authoritarian crime-fighting measures,${ }^{503}$ putting severe pressure on the Salvadoran State and its security institutions.

This pressure shaped the evolution of newly reformed state security institutions, their capacity to provide security, and their response to crime and violence. While discussions on SSR in El Salvador are often limited to the institutional reforms that took place in the direct aftermath of the civil war, I consider SSR to be a long-term transformative process. The actual institutional recast is only a first step towards the complete transformation of security and justice provision.

How the State responded to crime and violence from 2000 was strongly influenced by the reforms that took place in the 1990s and their shortcomings. Post-war reforms did

\footnotetext{
${ }^{500}$ Data presented in Amaya, "Security Policies in El Salvador, 1992-2002," 137.

${ }^{501}$ See Ellen Moodie's work about narratives of crime and violence that shaped post-war El Salvador. Moodie, El Salvador in the Aftermath of Peace.

${ }^{502}$ Popkin, "Building the Rule of Law in Post-War El Salvador," 1.

${ }^{503}$ See Alisha C. Holland, "Right on Crime?: Conservative Party Politics and Mano Dura Policies in El Salvador," Latin American Research Review 48, no. 1 (2013): 44-67, doi:10.1353/lar.2013.0009; Verónica de la Torre and Alberto Martín Alvarez, "Violencia, Estado de Derecho Y Políticas Punitivas En América Central," Perfiles Latinoamericanos 19, no. 37 (June 2011): 33-50.
} 
address some of the key concerns of the war: the lack of civilian oversight, authoritarianism, widespread human rights violation by state actors, and cronyism between the armed forces and political elites. However, the reform did not provide the PNC and the rest of the state apparatus with the right tools to adapt and face a changing security environment where the space left vacant by the guerrilla movement and other war-time actors was progressively filled by local gangs, private security companies, and transformed deaths squads.

\subsection{Mano Dura: state expansion through repression}

The academic literature has discussed at length Mano Dura (Iron Fist) as a crimefighting strategy in El Salvador and elsewhere in Central America. ${ }^{504}$ However, the analytical framework proposed here sheds new light on the consequences of attempts at State expansion in a pluralist POR where there are already powerful non-state actors with strong incentives to claim some control over the means of violence and public ordering.

My core argument is that through Mano Dura, the Salvadoran State sought to expand its authority over the POR and eliminate non-state actors considered undesirable. However, the lack of a well-planned and properly resourced strategy prevented the State from successfully expanding its control over the means of violence in spaces where street gangs were particularly active. State security institutions relied on both formal and informal public ordering mechanisms to target street gangs. Consequently, Mano Dura had important distributive implications for local cliques, who relied increasingly on

\footnotetext{
${ }^{504}$ See, for example, Thomas Bruneau, Lucía Dammert, and Elizabeth Skinner, Maras: Gang Violence and Security in Central America (Austin: University of Texas Press, 2011); Fariña, Miller, and Cavallaro, No Place to Hide; Mo Hume, "Mano Dura: El Salvador Responds to Gangs," Development in Practice 17, no. 6 (2007): 739-51; Geoff Thale, "Las Pandillas Juveniles Centroamericanas Y La Repuestas de 'Mano Dura," Quorum, no. 16 (2006): 51-61; Thale and Falkenburger, "Youth Gangs in Central America. Issues on Human Rights, Effective Policing, and Prevention."
} 
extortion and drug distribution as a main source of income. The State's intervention disrupted gangs' claims over the means of violence, which then sought to reinforce and expand their territorial claims to intensify revenue from extortion and other rent-seeking activities. As a result, the level of public order in the Salvadoran POR decreased importantly, as illustrated by the reverse trend in the national homicide rate from 2003.

Figure 2 National homicide rate, EI Salvador, 2000-2007

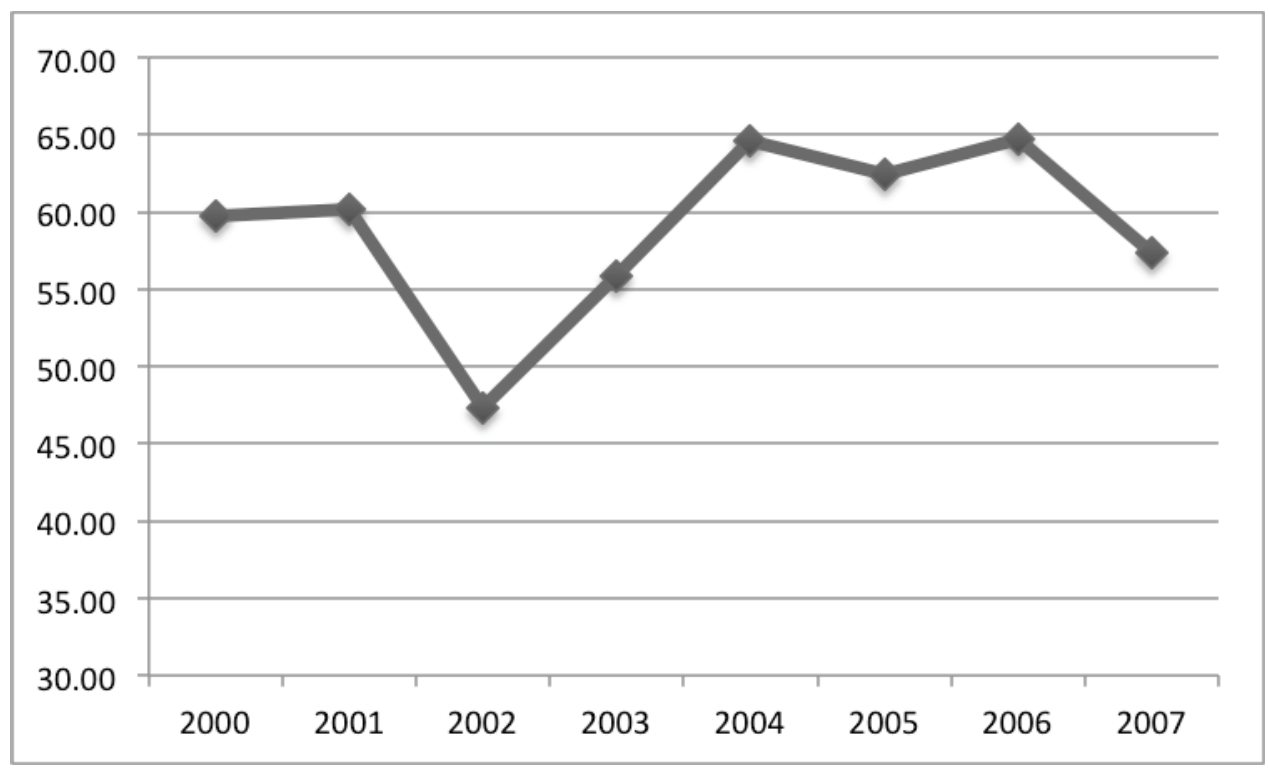

Source: Policía Nacional Civil

I first describe the Mano Dura measures adopted by Francisco Flores' government in the summer of 2003 and highlight how it sought to expand State's authority over the regime. The objective was not to establish a monopoly of the State over the formal use of violence, but rather to get rid of some non-state actors who were portrayed as the main source of insecurity in the country. I then discuss the consequences of Mano Dura on the structure of the POR, and the resulting level of public order.

\subsubsection{Mano Dura: a state expansion strategy}

In an official message transmitted on national television and radio on July 23, 2003, president Francisco Flores announced the operation Mano Dura. He stated: 
Across the country criminal gangs called maras have taken possession of an enormous quantity of neighbourhoods and communities to commit numerous and terrible crimes. This does not only threaten the neighbours in these territories of the maras but the whole country. There are more armed mareros than police and military personnel together, and thus they represent a threat for all Salvadorans. [...] Today, the 23 of July, I have instructed the Policía Nacional Civil and the armed forces to rescue jointly those territories and put behind bars the leaders of those gangs. [...] This is the moment. In this battle against crime we will use all legitimate means, including some exceptional measures recognized by the constitution. [...] These gangs assassinate on average 100 persons each month. [...] These criminal organisations have taken hostage entire communities. They control theses territories and charge war taxes to their inhabitants. ${ }^{505}$

In his message to the nation, Flores highlighted the territorial control of gangs and the economic activities deriving from their ability to successfully claim such control. The implied objective of the Salvadoran State under Mano Dura was to expand its authority through force in order to reclaim control over those means of violence and eliminate disruptive actors.

The Congress adopted in October 2003 the Ley Anti Maras (Anti-Maras Act - LAM I) for an initial period of six months. ${ }^{506}$ LAM I allowed the Salvadoran Government to

\footnotetext{
${ }^{505}$ Francisco Flores, "Mensaje Emitido En Cadena de Radio Y Telivision Po El Presidente de La Republica, Francisco Flores, Durante El Anuncio de La Operacion 'Mano Dura' contra Las Pandillas" (San Salvador, El Salvador, July 23, 2003).

${ }^{506}$ Decreto [Decree] No. 158/2003, Ley Anti-Maras [Anti-Gangs Act] (2003), available at http://www.copades.com.sv/uploaded/content/category/leyes/LEY\%20ANTI\%20MARAS.pdf
} 
use military personnel in anti-gang operations, expanding the role of the armed forces in public security matters and increasing the State's capacity to use violence inside the POR. LAM I also criminalized gang membership, allowed the prosecution of juveniles as adults, and provided for the imposition of fines against individuals found wandering without identity papers.

LAM I was the first of a series of legislations that gave the State the legal basis to crack down on gangs and prosecute their members. ${ }^{507}$ It also coincided with the beginning of the presidential campaign leading to the March 2004 election. The bill was heavily criticized by local and international human rights organisations for violating the Constitution, the spirit of the peace accords, and international treaties. ${ }^{508}$ Nonetheless, President Flores made several public statements defying judges who would refuse to apply LAM I due to constitutional issues: "judges who say they cannot apply the law are siding with the criminal" and "we will fight until we overcome all obstacles thrown up by politicians and judges who are protecting these criminals." ${ }^{509}$ Presidential statements such as these quickly politicised the debate on crime-fighting policies, prevention any constructive discussion within the government and with the civil society. ${ }^{510}$ Nonetheless, LAM I received strong popular support, leading to the election in March 2004 of Antonio Saca, the presidential candidate for ARENA and successor of Francisco Flores.

\footnotetext{
${ }^{507}$ For a detailed discussion of gang-related legislation adopted under Mano Dura and Super Mano Dura, see Fariña, Miller, and Cavallaro, No Place to Hide, 108-31.

${ }^{508}$ Fariña, Miller, and Cavallaro provide the summary of several NGO reports criticizing plans Mano Dura and Super Mano Dura. Fariña, Miller, and Cavallaro, No Place to Hide; see also Amnesty International, "El Salvador: Open Letter on the Anti-Maras Act" (Amnesty International, December 2003).

${ }^{509}$ Excerpts from Salvadoran newspapers' articles from October 2003 cited in Amnesty International, "El Salvador: Open Letter on the Anti-Maras Act."

${ }^{510}$ For a detailed discussion of the politicization of LAM I, see Fariña, Miller, and Cavallaro, No Place to Hide, 20-23.
} 
The Supreme Court declared LAM I unconstitutional on April 1, 2004. ${ }^{511}$ The next day, the Congress adopted a new decree, the Ley Para el Combate de las Actividades Delincuenciales de Grupos o Asociaciones Ilícitas Especiales (Law to Combat Delinquent Activities of Special Illicit Groups or Associations - LAM II), for a 90-day period. ${ }^{512}$ LAM II essentially included the same provisions as LAM I and was deemed unconstitutional by members of the judiciary. Upon expiration, LAM II was not renewed. Instead, on August 30, 2004, newly elected president Antonio Saca proposed a new plan: Super Mano Dura. Super Mano Dura revived most of the elements of LAM I and LAM II, but, contrary to Mano Dura, the new plan included some prevention and reintegration components to rally political opposition. Mano Amiga (Friendly Hand) included prevention programs for youth at risk, while Mano Extendida (Extended Hand) targeted former gang members through rehabilitation efforts. ${ }^{513}$ These initiatives remained mostly rhetorical, however. ${ }^{514}$ They received only 20 percent of the government funding, with 80 percent of the available funds were directed to law enforcement. ${ }^{515}$

From 2003 to 2005, under plans Mano Dura (LAM I and LAM II) and Super Mano Dura, state security actors, often police-military joint task forces, would enter marginalised communities suspected of strong gang presence and arrest systematically any alleged gang member. Young men with tattoos were more often than not

\footnotetext{
${ }^{511}$ Sala de ley Constitucional de la Corte Suprema de Justicia [Constitutional Chamber of the Supreme Court of Justice] (Dec. 52-2003/56-2003/57-2003) at Falla 16 ; IV , 3, B (April 1, 2004).

${ }^{512}$ Decreto [Decree] No. 305/2004, Ley Para el Combate de las Actividades Delincuenciales de Grupos o Asociaciones Ilícitas Especiales [Law to Combat Delinquent Activities of Special Illicit Groups or Associations - LAM II] (

${ }^{513}$ Norma C. Gutiérrez, "El Salvador: Gang Violence" (Washington, D.C.: U.S. Law Library of Congress, December 2012).

${ }^{514}$ Sonja Wolf, "Mano Dura: Gang Suppression in El Salvador," Sustainable Security, March 1, 2011, https://sustainablesecurity .org/2011/03/01/mano-dura-gang-suppression-in-el-salvador/.

${ }^{515}$ USAID, "USAID Central American and Mexico Gang Assessment," 54.
} 
indiscriminately targeted. According to the former sub-director of the PNC, Commissioner Pedro Gonzalez, the objective of those large swipes was to convince other gang members to find something better to do, persuading them that gang membership was no longer a profitable and/or beneficial activity. ${ }^{516}$ Over the course of two years, from July 2003 and to July 2005, 30,934 alleged gang members were arrested, the wide majority only charged with gang membership by the FGR.$^{517}$ Between July 2003 and August 2004, Mano Dura led to 19,275 arrests, according to PNC numbers. ${ }^{518}$ Almost 13,000 more were apprehended under Super Mano Dura. ${ }^{519}$

\subsubsection{Problems with Mano Dura ${ }^{520}$}

Under Mano Dura, repression directed toward gangs, undesirable coercive actors, was the key strategy to expand state authority through the POR. However, early advocates of the plan later recognized that Mano Dura was ineffective. René Figueroa, former Minister of Public Security under President Antonio Saca, stated in an interview that if Mano Dura was essential to address crime and violence, the PNC did not have the necessary resources to deliver its mandate. There was little international funding to support the developing police force at that time, and the support of the armed forces was

\footnotetext{
${ }^{516}$ Edward Gutiérrez, "PNC Anuncia Caza de 309 Líderes de Clicas,” El Diario de Hoy, October 24, 2003, http://archivo.elsalvador.com/noticias/2003/10/24/nacional/nacio3.html.

${ }^{517}$ According to Cruz, the same individuals were arrested several times, which is not taken into consideration in the number provided above José Miguel Cruz, "Government Responses and the Dark Side of Gang Suppression in Central America," in Maras: Gang Violence and Security in Central America, ed. Thomas Bruneau, Lucía Dammert, and Elizabeth Skinner (Austin: University of Texas Press, 2011), 143; Fariña, Miller, and Cavallaro, No Place to Hide, 21.

${ }^{518}$ Carlos Garcia, "Tracing the History of Failed Gang Policies in US, Northern Triangle," Insight Crime, December 3, 2015, http://www.insightcrime.org/news-analysis/tracing-the-history-of-failed-gang-policiesin-us-northern-triangle.

519 Ibid.

${ }^{520}$ Hereinafter, Mano Dura refers to LAM I, LAM II, and the plan Super Mano Dura.
} 
insufficient. $^{521}$ For Figueroa, in other words, the problem was a lack of resources, undermining the capacity of the State to eliminate gangs in the POR.

Indeed, the State's promise to increase pressure on gangs did not translate in an injection of resources throughout the criminal justice system. Equipment shortages, such as vehicles, fuel, and radios, severely limited the PNC's ability to deter and respond effectively to crime, conduct investigation, and gather evidence. ${ }^{522}$ The situation was not better further down the criminal justice chain. The FGR, the courts, and the prisons system did not have the proper resources to face such a flow of arrests. Most arrests were based on gang membership, and the FGR usually had no evidence that other crimes had been committed. Due to constitutional issues, judges refused to apply contested provisions making gang membership a punishable offence. Individuals would then be released, only to be arrested again shortly after. ${ }^{523}$ Of the 19,275 people arrested in the first year of the Mano Dura, 95 percent were released in court due to the debated constitutionality of the law and judges' refusal to hear those cases.$^{524}$

Attacks by seniors governments officials on the judiciary posed serious threats to the rule of law. Judges felt pressured by the political branch to apply Mano Dura. To circumvent resistance from the courts to apply the consecutive measures composing Mano Dura, the Flores and Saca administrations resorted to influencing the judges'

\footnotetext{
${ }^{521}$ Interview with René Figueroa, former minister of public security, San Salvador, June 2015.

${ }^{522}$ U.S. Overseas Security Advisory Council, "El Salvador: 2006 Crime and Safety Report" (Washington, D.C.: U.S. Department of State, Bureau of Diplomatic Security, October 4, 2006).

${ }^{523}$ The refusal of the Attorney General Office (Fiscalía General de La República) to prosecute alleged gang members due to the lack of evidence actually created tensions between the different components of the security and justice sector. See E. A. Amaya Cobar and O. E. Feusier Alaya, "Relación Entre La Fiscalía General de La República Y La Policía Nacional Civil En El Marco de La Investigación Criminal" (San Salvador, El Salvador: FESPAD, 2005).

${ }^{524}$ Amaya Cóbar, "Quince Años De Reforma Policial En El Salvador : Avances Y Desafíos," 138; FESPAD and CEPES, "Informe Anual Sobre Justicia Penal Juvenil El Salvador 2004” (FESPAD, 2005), http://www.wola.org/sites/default/files/downloadable/Citizen\%20Security/past/IPJ2004.pdf.
} 
nomination and promotion processes, threatening judges who would refuse to apply antigang legislation, and creating special courts to process gang members. ${ }^{525}$

In cases where charges were brought, the right to a fair trial was often hampered by political pressure on the judiciary and the lack of due process during the procedures. Fariña and her colleagues cite the Director of the Victim and Witness Protection Program: "the prosecutors would consider their job done when they find a witness." Little effort was put on triangulating witness testimonies with additional evidence. As a result, there was an incentive for individuals to testify to obtain someone's conviction, while, at the same time, witnesses became increasingly targeted since getting rid of them meant destroying evidence.

Table 6 Prison population, EI Salvador

\begin{tabular}{|l|l|l|}
\hline Year & Prison Population Total & Prison Population Rate \\
\hline 2000 & 7,754 & 130 \\
\hline 2002 & 10,907 & 181 \\
\hline 2004 & 12,073 & 199 \\
\hline 2006 & 14,771 & 242 \\
\hline
\end{tabular}

Source: World Prison Brief

As a direct result of Mano Dura, prison population increased sharply, well beyond the system capacity of 8,000 inmates (table 6) ${ }^{527}$ Between 2002 and 2004 , the number of underage inmates more than doubled, passing from 1,526 to 3,258 according to PNC statistics. ${ }^{528}$ While these numbers are small in comparison to prison population elsewhere, the Salvadoran prison system was one of the most overcrowded in the region and gang

\footnotetext{
${ }^{525}$ See Fariña, Miller, and Cavallaro, No Place to Hide, 18-21.

${ }^{526}$ Interview with Mauricio Rodríguez, Director del Programa de Proteccion de Victimas y Testigos, San Salvador, 22 January, 2009, reported in Ibid., 121.

${ }^{527}$ FESPAD and CEPES, "Informe Anual Sobre Justicia Penal Juvenil El Salvador 2004,” 35.

${ }^{528}$ Ibid.
} 
members composed an important part of its population. ${ }^{529}$ Due to the lack of resources and overpopulation, incarceration conditions were despicable and violence behind bars was common. For instance, in March 2004, 31 inmates died, most of them after being stabbed. Two prison guards were later charged in that case for "homicide, attempted homicide, illegal association and allowing forbidden materials (which were used in the murders) to be brought into the prison." 530

Finally, few resources were assigned to increasing sustainably the State's presence in marginalized communities where cliques had managed to impose themselves. In a climate of economic stagnation, most resources were directed towards punctual repression for government officials to show publically that they were actively fighting crime and insecurity. Short-term political gains outweighed long term social and economic costs. Despite the fact that Super Mano Dura included a prevention and reinsertion component, the Mano Amiga, René Figueroa suggested that it was the responsibility of international donors to fund violence prevention activities in the context of limited state resources. ${ }^{531}$

\subsection{Consequences of Mano Dura on the public order regime}

Mano Dura had unforeseen consequences on the structure of the POR and the level of public order it produced. Ill-adapted strategy to expand state authority over the regime and supress undesirable non-state coercive actors actually disrupted existing public ordering mechanisms and reduced the resulting level of public order produced by the POR, illustrated by a rise in homicides and heavier reliance on violence to impose order.

\footnotetext{
${ }^{529}$ USAID, "USAID Central American and Mexico Gang Assessment," 52.

${ }^{530}$ Amnesty International, “Amnesty International Report 2005 - El Salvador,” May 25, 2005, http://www.refworld .org/docid/429b27f67.html.

${ }^{531}$ Interview with René Figueroa, former minister of public security, San Salvador, June 2015.
} 
Mano Dura intensified informal public ordering by state and non-state actors, justifying the use of extrajudicial violence by state institutions and death squads on the one hand, and the reinforcement of gangs' claims over the means of violence on the other hand. State repression led to the intensification of gangs' extortion activities, which increased competition between rival cliques for the control of extortion and drug distribution markets. Ultimately, Mano Dura had the exact opposite effect to the one that was announced: violence and crime increased sharply as illustrated by the national homicide rate which rose from 47.34 in 2002 to 64.66 in 2006 (see figure 2).

\subsubsection{State public ordering}

Adopting a strong repressive rhetoric, the State flexed its muscles in order to eliminate competing coercive actors who were portrayed as the main cause of insecurity. Yet, insufficient resources and the lack of a coherent strategy through the criminal justice chain prevented the State to sustainably expand its claim over the POR and suppress gangs. Resistance from the judiciary to apply legislation considered unconstitutional generated strong pressure from the executive on judges and ultimately led to the establishment of specialised tribunals chaired by political appointees to prosecute individuals arrested through large anti-gang operations. Mano Dura also provided fertile grounds for informal public ordering by state actors. The measures adopted by the Salvadoran government "promote[d] discretionary crimes, constrict[ed] due process rights, and involve[d] the military in policing." ${ }^{532}$ It blurred the lines between police and

\footnotetext{
${ }^{532}$ Holland, "Right on Crime?," 46.
} 
military functions, increased the arbitrary authority of the PNC, and fostered a climate of tolerance for abuses and extrajudicial violence..$^{533}$

\subsubsection{Formal public ordering}

Selective state policing in communities with strong gang presence was a staple of Mano Dura. Security provision and protection by the State's security institutions only concerned the "good, hard working Salvadorans." 334 Gangs and people living in gangrelated communities came to only know the PNC as a repressive tool. For instance, LAM I and LAM II authorized profiling based on physical appearance. In the early 2000s, gangs relied heavily on tattoos to show their affiliation. Over time however, since tattoos made them more vulnerable to arrest, gang leaders started giving orders prohibiting new visible tattoos. Hence, distinguishing between gang members and other youth became increasingly difficult. The release of the vast majority of individuals arrested under Mano Dura suggests that the PNC would arrest indiscriminately young males in high-risk communities without much concern for actual involvement in criminal activities other than gang membership. Under Super Mano Dura alone, 10,000 of the 14,000 individuals arrested were released without charges. ${ }^{535}$

In addition to being indiscriminately targeted by the PNC, poor young males would often not benefit from the protection of the police. Based on interviews conducted with a

\footnotetext{
${ }^{533}$ Thale, "Las Pandillas Juveniles Centroamericanas Y La Repuestas de 'Mano Dura."”

${ }^{534}$ During my time conducting field research in El Salvador, I had numerous conversations with Salvadorans of different socio-economic backgrounds referring to themselves and their community as hardworking, law-abiding citizens. They would then often refer to gang members as opportunistic and lazy individuals who were not part of the Salvadoran society.

${ }^{535}$ Clare Ribando Seelke, "Gangs in Central America," CRS Report for Congress (Washington, DC: Congress Research Service, January 3, 2011), 11.
} 
17 years-old inmate in the juvenile detention centre of Ilobosco, Fariña and her coauthors recount:

The youth, the oldest male in his family, increasingly became a target for [La18] members, who harassed him, threatened him, and stole from him when he left his house. According to the version told [...] by the adolescent, instead of providing protection to the adolescent or his family, police in the area regularly stopped him and searched the boy, and sometimes arrested him on illicit association charges. ${ }^{536}$

This excerpt describes how the teenager was cut between two fires. On one side, while the boy was not a member of a gang, PNC officers constantly targeted him. At the same time, the local clique would use coercion against him to assert their authority and collect rent. This anecdote suggests that, under Mano Dura, some groups were victimized by both state and non-state actors, resulting in an increase in the relative weight of informal public ordering inside the regime and a lower level of public order.

\subsubsection{Informal public ordering}

When it comes to state informal public ordering, organisations from the civil society, including the Salvadoran Catholic Church, raised important concerns about death squads targeting gang members. ${ }^{537}$ Following the implementation of Mano Dura, there were reports by media and civil society organisations of extrajudicial killings conducted by PNC officers. Testimonies suggest that, under Mano Dura, PNC officers could kill

\footnotetext{
${ }^{536}$ Fariña, Miller, and Cavallaro, No Place to Hide, 159.

${ }^{537}$ Sam Savage, "El Salvador Death Squads Targeting Criminals: Church,” Reuters, June 15, 2006, http://www.redorbit.com/news/international/539971/el_salvador_death_squads_targeting_criminals_church 1.
} 
alleged gang members without many consequences. For instance, according to 2006 documents from the National Human Rights Ombudswoman, witnesses reported that two police officers shot in the back an alleged gang member. The case was later dropped because witnesses refused to testify following the preliminary investigation. ${ }^{538}$ Other reports attest that police officers showed up to a funeral gathering and summarily executed gang members ${ }^{539} \mathrm{All}$ in all, there is a shared understanding among experts that, under Mano Dura, extrajudicial violence against gangs was encouraged or at least tolerated..$^{540}$

\subsubsection{Non-state public ordering}

Mano Dura operations sought to supress gangs and their influence on Salvadoran communities. Yet, the Iron Fist approach actually had the opposite effect on the POR: it ultimately reinforced gangs and increased pluralism. Furthermore, the incapacity of the State to provide security to the population only accelerated the proliferation of private security firms and death squads unrelated to state security institutions. As a result, public order and security became increasingly a private affair, where citizens able to pay for their own security would hire security guards or support in one way or another vigilante groups, while poor Salvadorans would be caught in the crossfire between the State, the gangs, and vigilante groups.

\subsubsection{Gangs}

\footnotetext{
${ }^{538}$ Fariña, Miller, and Cavallaro, No Place to Hide, 184.

${ }^{539}$ Ibid.

${ }^{540}$ Holland, "Right on Crime?"; Cruz, "Government Responses and the Dark Side of Gang Suppression in Central America"; Wolf, "Street Gangs of El Salvador"; Thale, "Las Pandillas Juveniles Centroamericanas Y La Repuestas de "Mano Dura."
} 
The constant flow of gang members going through detention centres shifted the locus of gang structure from local communities toward national prisons. As a result, local cliques became increasingly linked to one another and started coordinating their activities. Prison segregation discussed earlier only intensified this phenomenon. ${ }^{541}$ Interviews conducted in 2005 by a USAID assessment team with infiltrated PNC officers revealed that cliques would meet periodically with national-level leadership to plan criminal actions for the entire gang. ${ }^{542}$ High imprisonment rate also facilitated recruitment; gangs recruited youth who were mistakenly incarcerated on charges of gang membership.

Furthermore, poor prison conditions meant that cliques had to provide for the wellbeing of their incarcerated members and their family. Hence, as the number of gang members imprisoned increased, pressure on cliques to provide for their members also rose. Advocacy groups, such as OPERA ${ }^{543}$ in the prison of Cohutepeque, were created to defend the rights of inmates and denounced conditions of incarceration, with more or less results. According to one of the former coordinators of the program, the objective was "to plant the seed of non-violent protest to present official demands through the right channels." ${ }^{544}$

\footnotetext{
${ }^{541}$ Interview with Douglas Moreno, Ilopango, September 2013.

${ }^{542}$ USAID, "USAID Central American and Mexico Gang Assessment," 45.

${ }^{543}$ OPERA has since evolved. Some stakeholders met in El Salvador argued that OPERA has been completely co-opted by the gangs. The same is said about other organisations originally created to represent retired gang members and advocate for reinsertion, such as Homies Unidos. There is nonetheless a clear incentive for proponent of the hard line against gangs to delegitimise those initiatives.

${ }^{544}$ Interview with a program coordinator for second-chance project, Catholic Relief Services, San Salvador, May 30, 2015.
} 
Despite these efforts, rising imprisonment rates contributed to the expansion and the intensification of extortion rackets, the main source of income for Salvadoran gangs. ${ }^{545}$ Intensifying illegal activities meant a heavier reliance on violence, at least at first to reaffirm and expand gangs' claim over extorted communities and contested turfs. Competition for territorial control fed the growing war opposing the MS-13 and La18, which had disastrous consequences for El Salvador crime rates. In 2006, according to the OSAC Crime and Safety Report, "gang shootings of bus drivers and bus free takers [was becoming] a daily occurrence." ${ }^{, 56}$ Interestingly enough, some cliques also established small formal businesses where their capacity to use coercion enabled them to compete unfairly against other local businesses, such as bus companies.$^{547}$

Finally, Mano Dura had disruptive consequences on communities, targeting systematically young men who had very few economic opportunities to start with and widening the gap between those close to the gangs and the rest of the population. In Ilopango, a municipality of the greater San Salvador, Mano Dura coincided with the closure of multinationals' factories, which were the main employers in the municipality. The lack of employment in the formal economy further reinforced local cliques and illegal markets. By 2006, the PNC estimated gang membership across the country at $16,000$, but estimates from different sources vary widely (from 10,000 to 40,000$).{ }^{548}$ In

\footnotetext{
${ }^{545}$ Interview with José Miguel Cruz cited in USAID, "USAID Central American and Mexico Gang Assessment," 53; Wim Savenije and Chris van der Borgh, "Anti-Gang Policies and Gang Responses in the Northern Triangle," The Broker - Connecting Worlds of Knowledge, accessed March 7, 2016, http://www .thebrokeronline.eu/Articles/Anti-gang-policies-and-gang-responses-in-the-Northern-Triangle. ${ }^{546}$ U.S. Overseas Security Advisory Council, "El Salvador: 2006 Crime and Safety Report."

${ }^{547}$ Steven C. Boraz and Thomas Bruneau, "Are the Maras Overwhelming Governments in Central America?," Military Review, no. November-December (2006): 39.

${ }^{548}$ U.S. Overseas Security Advisory Council, "El Salvador: 2006 Crime and Safety Report.”
} 
sum, repressive measures and extra-legal violence by the State only contributed to increase gang membership, their level of organisation, and their reliance on violence..$^{549}$

\subsubsection{Vigilante groups}

Following the implementation of Mano Dura, testimonies suggest that homicides committed by social cleansing groups increased sharply. As discussed above, some of these groups appeared to be linked to the PNC and the armed forces, while others were not related to state institutions. In any case, these groups supplemented incomplete formal public ordering provided by state security institutions in marginalised communities. A 2004 survey reveals that almost 20 percent of the participants considered that taking justice in their own hands was necessary to ensure their safety and security. Jeannette Aguilar, director of the IUDOP, argues: "there is increased evidence of social cleansing. Faced with a state that is incapable of guaranteeing citizen security, these groups come into play. There is an increase in the last several years of homicides of gang members, committed not just by other gang members." ${ }^{550}$ Going even further, José Miguel Cruz contends that Mano Dura provided the "ideological and rhetorical support" for vigilante groups and death squads. ${ }^{551}$

The phenomenon was so serious that some international and domestic human rights organizations attributed the increase in homicides from 2002 to 2005 in large part to

\footnotetext{
${ }^{549}$ See, for example, Cruz, "Government Responses and the Dark Side of Gang Suppression in Central America"; José Miguel Cruz, "Criminal Violence and Democratization in Central America: The Survival of the Violent State," Latin American Politics and Society 53, no. 4 (2011): 1-33.

${ }^{550}$ Interview with Jeannette Aguilar, director, IUDOP, San Salvador, August 24, 2006, reported in Fariña, Miller, and Cavallaro, No Place to Hide, 201.

${ }^{551}$ Interview with José Miguel Cruz, then director of the IUDOP, San Salvador, March 31, 2006, reported in Fariña, Miller, and Cavallaro, No Place to Hide; see also Cruz, "Government Responses and the Dark Side of Gang Suppression in Central America."
} 
death squads. ${ }^{552}$ In a 2004 report, the Fundación de Estudios para la Aplicación del Derecho (Study Foundation for the Application of the Law - FESPAD) describes how killings perpetrated by death squads usually followed the same patterns: people were shot at gun point in the head, usually by masked individuals from a motorcycle or a vehicle, and their body was left in public places, on the side of the road, or in creeks. ${ }^{53}$ Specific, verifiable anecdotes are however difficult to come by, and people were not inclined to discuss those matters on the record during interviews.

Independently of the size of the phenomenon, the sole notion of active vigilante groups suggests that formal state security provision was limited and unable to actually address sources of insecurity and disorder. As a consequence, informal groups took into their own hands to produce public order, targeting individuals and groups perceived as disruptive and dangerous. The involvement of state coercive actors in informal public ordering through death squads further suggests that state formal public ordering was not sufficient enough to produce a relatively high level of public order, and that using informal means was perceived as a necessary complement for some active members of the security forces.

\subsubsection{Private security firms}

Private security firms continued to play an important role in public ordering after the implementation of Mano Dura in 2003. In the same survey revealing that one out of five

\footnotetext{
${ }^{552}$ See Fariña, Miller, and Cavallaro, No Place to Hide, 201-2; Savage, "El Salvador Death Squads Targeting Criminals: Church"; Thale and Falkenburger, "Youth Gangs in Central America. Issues on Human Rights, Effective Policing, and Prevention"; Thale, "Las Pandillas Juveniles Centroamericanas Y La Repuestas de 'Mano Dura'"; FESPAD and CEPES, "Informe Anual Sobre Justicia Penal Juvenil El Salvador 2004."

${ }^{553}$ José Miguel Cruz and Maria L. Santacruz Giralt, "La Victimización Y La Percepción de Seguridad En El Salvador En 2004” (Ministerio de Gobernacion, Républica de El Salvador; Program de las Naciones Unidas para el Desarollo, April 2005), 4.
} 
Salvadorans considered that taking justice into their own hands was the best way to ensure their security, 45.5 percent of participants agreed that hiring private security was necessary to their security. ${ }^{554}$ According to the executive director of the Asociación de Distribuidores de El Salvador (Association of Distributors of El Salvador), the PNC did little to protect small businesses, which were forced to limit their hours of operation or stay close due to the lack of security: "the PNC has the information [about crime and extortion], but they do nothing with it." 555 According to a 2005 World Bank survey on the investment climate in the country, "micro- and small firms reported that gangs were responsible for 46 percent and 37 percent, respectively, of the crime committed against them."

In sum, despite the fact that Mano Dura sought to expand state authority inside the POR and eliminate undesirable non-state coercive actors, pluralism inside the regime only increased in the years that followed the implementation of the Iron Fist strategy. Gangs managed to expand their control on the means of violence, extrajudicial violence committed by death squads and vigilante groups reappeared, and private security firms remained a key source of security for many Salvadorans. As a result, state public ordering became relatively less prevalent in the Salvadoran POR.

\subsection{Overall level of public order}

Sate expansion under Mano Dura backfired. Not only did it increase pluralism, but Mano Dura also led to a reduction of the overall level of public order produced by the regime. Violence rose sharply. National homicides increased from approximately 47 to

\footnotetext{
554 Ibid.

${ }^{555}$ Interview with Lic. Sonia Jule de Rivera, Executive Director, Asociación de Distribuidores de El Salvador, San Salvador, June 2015.

${ }^{556}$ USAID, "USAID Central American and Mexico Gang Assessment," 48.
} 
65 homicides per 100,000 people between 2003 and 2005. The Salvadoran government attributed the increase in homicides and the overall decline in the level of public order to gangs. In a presidential address in December 2005, President Antonio Saca stated that gangs were responsible for disorder in the streets of the country and more than 50 percent of murders perpetrated that year. ${ }^{557}$ For the same year, the PNC attributed 55 to 65 percent of homicides to gang violence. ${ }^{558}$ However, other sources have provided more modest estimates for 2005, considering that only 13.4 percent of homicides and 20 percent of all types of crime could be attributed with certainty to gangs. ${ }^{559}$

Qualitative assessment suggests that the level of public order was reduced in part because of non-state actors' higher reliance on violence. On the one hand, gangs used coercion to defend their turf and intensify their extortion networks. Furthermore, considering jails' limited resources, segregation based on gang affiliation, and the constant flow of detainees, prisons became national headquarters for the gangs, enabling local and regional leaders to coordinate and share information. Hence, repressive policies adopted by the successive ARENA governments only worsened the problem. On the other hand, the incapacity of the State to actually deal with gangs as well as tolerance for extrajudicial violence and impunity had an enabling effect on informal public ordering activities by death squads and vigilante groups, some actually linked to state security institutions.

\footnotetext{
${ }^{557}$ Hume, "Mano Dura," 741.

${ }^{558}$ U.S. Overseas Security Advisory Council, "El Salvador: 2006 Crime and Safety Report."

${ }^{559}$ FESPAD, "Informe Annual Sobre Justicia Penal El Salvador 2005" (San Salvador, El Salvador: FESPAD, 2006); de la Torre and Alvarez, "Violencia, Estado de Derecho Y Políticas Punitivas En América Central," 36-37.
} 
Despite Mano Dura's clear lack of results, Presidents Flores and Saca maintained the hard line against gangs. Not enough repression was perceived as the problem, rather than conflict within the judicial system about the constitutionality of Mano Dura, lack of resources throughout the criminal justice chain, and a prison system reinforcing gangs. Mano Dura strategy and rhetoric did not increase the sense of security within the population. Indeed, according to a survey conducted in 2004 , almost 50 percent of the participants consider that the PNC was very unlikely to capture criminals, making Salvadorans likely to turn to other coercive actors for security.

$* * *$

In conclusion, state expansion under Mano Dura had disruptive consequences for the production of public order in the Salvadoran POR. Despite reforms put in place after the war to ensure that state security institutions could produce public order and ensure the security of Salvadorans in accordance with good governance principles, the State never managed to successfully claim or get close to a monopoly on the use of coercive force inside the Salvadoran POR. After ignoring gangs through the 1990s, state security institutions proved incapable of eliminating competing coercive actors through repression between 2003 and 2005 .

Contrary to expectations, Mano Dura policies increased pluralism inside the Salvadoran POR, reducing the overall level of public order produced by the regime. Gangs became more cohesive and organised, relying more heavily on violence to assert their authority and claim control over the means of violence. Where the State did not manage to eliminate gangs through formal means, death squads and vigilante groups 
emerged, only destabilizing further the regime. As a result, violence increased throughout the POR and the overall level of public order declined.

Mano Dura illustrates how ill adapted repressive strategies to expand the State's claims on the means of violence can actually backfire. In the Salvadoran POR, non-state actors had clear incentives to assert their authority and use violence in order to control individuals' behaviours. Gangs did so to expand their extortion rackets, while death squads filled the space left vacant by the State to counter-act against gangs' violence and perceived disruption. El Salvador shows how expanding claims over the means of violence in a pluralist POR is a risky endeavour that can have important consequences for the long-term stability of the regime, as well as for the development of security institutions in line with current SSR principles and objectives. 


\section{Chapter: El Salvador (2009-2014) - Failed Reforms and Violence}

\section{Management under Mauricio Funes}

20 years after the battle of San Salvador that forced a negotiated solution to the civil war, the FMLN led by Mauricio Funes won the 2009 presidential election. Walking into the presidential house, Funes faced a country profoundly marked by violence and crime. That year, the national homicide rate reached 70 homicides per 100,000 people. In response to the dire security situation, the first FMLN government presented a new public security policy, which included institutional reforms. Hence, more than 15 years after the signature of the peace accord, SSR remained a priority of the Salvadoran government and a mean to improve security in the country. However, despite the new policy introduced by the FMLN, results were slow to show. Homicide rates remained at similar levels through 2010 (64.7) and 2011 (69.2). ${ }^{560}$ Yet, in March 2012, they dropped abruptly, from 14 to six homicides a day. ${ }^{561}$ The online newspaper El Faro soon revealed that the Mara Salvatrucha and the Barrio 18 gangs had brokered a truce, halting violence. ${ }^{562}$ While the role of the government in the process was unclear at first, information revealed in the following months that the State had played an active role in the process. ${ }^{563}$

In this chapter, I argue that the failure of the Funes administration to implement reforms and reduce crime and violence led the State to facilitate the establishment of a

\footnotetext{
${ }^{560}$ UNODC, “Intentional Homicide, Count and Rate per 100,000 Population (1995 - 2011)."

${ }^{561}$ José Miguel Cruz and Angélica Durán-Martínez, "Hiding Violence to Deal with the State Criminal Pacts in El Salvador and Medellin,” Journal of Peace Research, February 22, 2016, 22343315626239, doi:10.1177/0022343315626239.

${ }^{562}$ Martínez et al., "Gobierno Negoció Con Pandillas Reducción de Homicidios."

${ }^{563}$ Carlos Martinez and José Luis Sanz, "La Nueva Verdad Sobre La Tregua Entre Pandillas," Elfaro.net, September 11, 2012, http://www.salanegra.elfaro.net/es/201209/cronicas/9612/La-nueva-verdad-sobre-laTregua-entre-pandillas.htm; Cruz and Durán-Martínez, "Hiding Violence to Deal with the State Criminal Pacts in El Salvador and Medellin."
} 
truce between the country's two most important gangs. SSR, traditionally conceived as a key process to reduce armed crime and violence, ${ }^{564}$ became part of the solution to address violent non-state actors and increase the relative weight of formal state institutions in the Salvadoran POR. Yet, reforming state security institutions in a context of constant public security crisis proved to be impossible. The truce became a way for participants and supporters to reduce violence and stabilise the POR. By bringing to the table non-state coercive actors and altering the incentive structure faced by gangs, the process increased the level of public order produced by the POR.

As demonstrated in the previous chapter, the post-war Salvadoran POR war resolutely pluralist. Through the country, state and non-state coercive actors produced public order through formal and informal means. Recent policy and academic research support this argument and highlight how complex the situation continued to be. ${ }^{565}$ State security institutions act formally and informally, as illustrated by recurring extrajudicial violence. Death squads have attracted the attention of medias and civil society periodically, and private security contractors are part of the daily landscape. Organized crime related to money laundering, as well as human and drug trafficking, has been increasingly pointed at as a destabilizing factor in the country. Nonetheless, in this chapter, I focus specifically on two coercive actors, the State and the gangs, as they are the main driving forces when

\footnotetext{
${ }^{564}$ OECD-DAC, The OECD DAC Handbook on Security System Reform (SSR): Supporting Security and Justice.

${ }^{565}$ See, for example, Sarah Kinosian, Angelika Albaladejo, and Lisa Haugaard, "El Salvador's Violence: No Easy Way Out" (Security Assistance Monitor, August 2016); Daugherty, "Uniformed Men Massacre Alleged Gang Members in El Salvador"; Bruneau, "Pandillas and Security in Central America"; Douglas Farah, "Organized Crime in El Salvador: The Homegrown and Transnational Dimensions," Working Paper Series on Organized Crime in Central America (Latin American Program, Woodrow Wilson International Center for Scholars, February 2011); Ministerio de Justicia y Seguridad Publica, "Política Nacional de Justicia, Seguridad Publica Y Convivencia” (El Salvador, 2012), http://www .aecid.org.sv/wpcontent/uploads/2014/01/Poli\%C2\%B4tica-Nacional-de-Justicia21.pdf?82a9e7.
} 
it comes to violence in the country. The impact of other forms of organized crime on violence is minimal compared to gangs, as discussed elsewhere. ${ }^{566}$

I first discuss the evolution of security policies and public order in the country following the election of Mauricio Funes at the head of the FMLN in 2009. Despite a new public strategy promoting institutional reforms, prevention, and reinsertion, state security institutions remained highly repressive and homicides reached new summits. Second, I describe the pluralist POR that characterized El Salvador from 2009 to March 2012. The State was relying more heavily on the armed forces alongside the Policía Nacional Civil to impose order and fight criminal violence, while the gangs used violence and coercion to reaffirm their authority and push back against the State. Third, I turn to the truce, describing how the ceasefire was first negotiated in early 2012 and then maintained through the following months. In early 2013, the second phase of the truce was implemented through the establishment of municipalities free of violence. However, beginning in May 2013, the truce progressively deteriorated. Fourth, I discuss how the truce reduced violence inside the POR. On the one hand, it created opportunities for the State to expand its authority in peripheral communities and develop new practices in lines with the reforms included in the 2009 public security policy. On the other hand, it formalized to a certain extent gangs' claims over the production of public order in the regime and limited their ability to use violence indiscriminately. Yet, the presidential campaign and the political costs associated to supporting the truce derailed the process. The truce collapsed when it became clear that the State would no longer support the deal.

\subsection{Public security and SSR under the FMLN, 2009-2012}

\footnotetext{
${ }^{566}$ See, for instance: Farah, "Organized Crime in El Salvador: The Homegrown and Transnational Dimensions."
} 


\subsubsection{Homicides in post-Mano Dura El Salvador}

As discussed in the previous chapter, Mano Dura had little positive impact on armed crime and violence in El Salvador in the early 2000s. Homicides numbers remained high after 2005, despite a modest decline from 2006 to 2008. Homicides increased again sharply in 2009 , reaching more than 70 murders per 100,000 people. Those numbers remained extremely high until March 2012. The national homicide rate dropped by approximately 40 percent in 2012 and 2013, coinciding with the gang truce. The reduction in murders lasted until 2014, when the national rate rose to levels similar to the pre-truce period.

Figure 3 National homicide rate, EI Salvador, 2005-2014

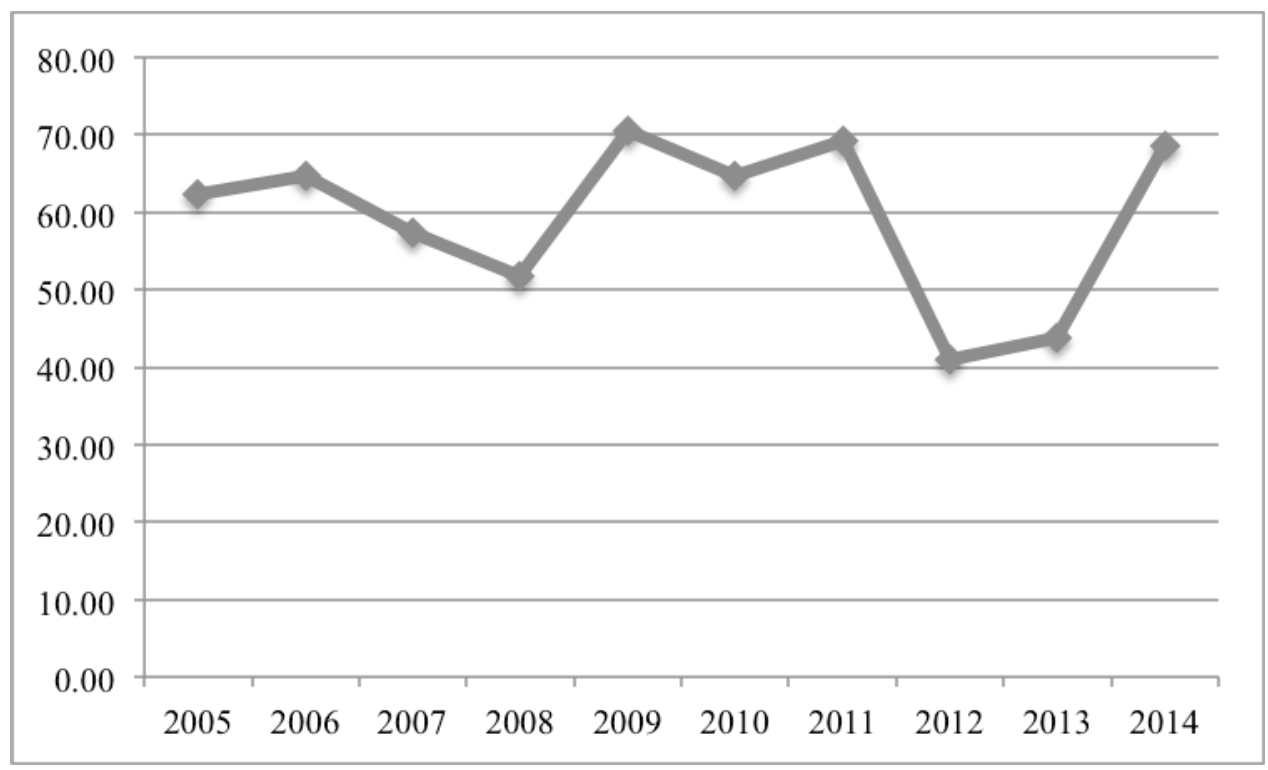

Source: Policía Nacional Civil

According to the Ministerio de Justicia y Seguridad Publica (Ministry of Justice and Public Security - MJSP), 75 to 80 percent of homicides from 2005 to 2008 were the 
result of firearm wounds. ${ }^{567}$ Violence also targeted specific groups within the population. More than 50 percent of people killed every year between 2008 and 2011 were between 15 and 29 years old. ${ }^{568}$ Of that number, over 90 percent were men. Hence, while homicides in El Salvador reached epidemic levels, armed violence did not have an indiscriminate effect on the Salvadoran population. Victims of homicide were mostly young males, the same group forming the vast majority of gangs' membership.

\subsubsection{5-2008: early efforts towards prevention}

The failure of Mano Dura policies created space in the public debate and the policymaking process for questions of reform, prevention, and reintegration. Mano Amiga (Friendly Hand) and Mano Extendida (Extended Hand) were first steps in that direction. After 2005, many donors, including USAID, UNDP, and the Inter-American Development Bank (IDB), funded community-oriented programs targeting youth at risk in low-income communities. ${ }^{569}$ Most of these programs appeared to have a positive impact locally. According to an evaluation report on USAID's community-based crime and violence prevention approach in Central America, surveys conducted in communities

targeted by these programs found that residents were less victimized and felt safer. ${ }^{570}$ However, the positive impact of these programs at the local level failed to be transposed

\footnotetext{
${ }^{567}$ Ministerio de Justicia y Seguridad Publica, "Política Nacional de Justicia, Seguridad Publica Y Convivencia," 7.

${ }^{568}$ Ibid., 69.

${ }^{569}$ As pointed out by a senior ministerial advisor from the MJSP, repression "generated the rejection of gangs as a concept." Hence, most donors would refuse to engage directly with gang members, funding prevention rather than rehabilitation programs. However, preventing gang members to participate to these initiatives has hardly been feasible. Interview with a ministerial advisor, Ministry of Justice and Public Security, San Salvador, July 2013.

${ }^{570}$ Susan Berk-Seligson et al., "Impact Evaluation of USAID's Community-Based Crime and Violence Prevention Approach in Central America: Regional Report for El Salvador, Guatemala, Honduras and Panama" (Nashville TN: Latin American Public Opinion Project/Vanderbilt University, October 2014), 4.
} 
to the national level, and there was little emphasis on prevention and reintegration in the public debate.

\subsubsection{Renewed SSR efforts under Funes}

\subsubsection{A new public security policy}

In 2009, many observers expected a move toward more progressive public security policies following the election of Funes. Prior to its election, the FMLN had put in place a consultation process to elaborate a new public security policy in collaboration with nongovernmental and civil society organisations. ${ }^{571}$ Between October 2007 and December 2008 , the party organized 32 thematic roundtables at the community level to get a better sense of the priorities of the population and to set a security agenda answering those expectations. These consultations informed the redaction of the Politica Nacional de Justicia, Seguridad Publica y Convivencia (National Policy for Justice, Public Security, and Coexistence - PNJSPC). The new policy included five core pillars around which the State would structure its intervention in the security sector: crime control and repression, social prevention of violence and crime, rehabilitation and reinsertion, victim support, as well as institutional and legal reforms. ${ }^{572}$

The PNJSPC poses a severe verdict on the condition of the security and justice sector at the end of the 2000s. First, it emphasizes how chronic institutional weakness continued to characterize the State's security and justice sector. The document identifies some key issues such as the lack of continuity and sustainability in the elaboration and the

\footnotetext{
${ }^{571}$ Interview with the coordinator for the program on citizen security and criminal justice, FESPAD, San Salvador, September 2013.

${ }^{572}$ Ministerio de Justicia y Seguridad Publica, "Política Nacional de Justicia, Seguridad Publica Y Convivencia."
} 
implementation of public policies, the manipulation and perversion of national institutions to fulfill objectives outside of their mandate, the lack of transparency and coordination between actors, and deficits in service provision towards the most vulnerable segments of the population. ${ }^{573}$ The document also denounces how insecurity and violence had traditionally been treated as a one-dimensional phenomenon, leading to reactive and unsophisticated policies that required significant financial resources without any strategic planning. Overall, the document argues that previous reforms were uncoordinated and lacked coherence, pointing to the 43 reform processes and 400 resulting modifications that targeted the 1998 Penal Code in only 10 years. ${ }^{574}$

Regarding the PNC specifically, the new strategy argues that, because of the lack of a structured and articulated policy guiding the MJSP, political actors had instrumentalised and manipulated the police force to achieve ends different than those established legally. ${ }^{575}$ The document identifies other key issues with the PNC: the lack of popular confidence in the police force leading to a deficit in credibility, the increasing disorganization of the PNC and its incapacity to adapt to social demands for security, lack of personnel and incentive to pursue a police career, the politicization of the institution, the weakness of disciplinary mechanisms, especially at the executive level, as well as the weakening of the delegation as a territorial reference and its disconnection from the community.

Finally, the PNJSPC denounces how impunity still prevailed in the criminal justice system at the end of the 2000s, despite previous judicial reforms. Indeed, only 4 percent

\footnotetext{
${ }^{573}$ Ibid., 15.

574 Ibid.

${ }^{575}$ Ibid., 19.
} 
of all cases of homicides led to a verdict, and approximately 85 percent of homicide cases were archived without trial. ${ }^{576}$ These appalling numbers suggest important flaws in terms of investigative capacities and expertise, coordination problems along the criminal justice chain, and potential lack of interest in pursuing criminal cases. Nonetheless, impunity did not translate into low levels of incarceration. In its diagnostic of the security institutions, the PNJSPC also states that the Salvadoran prison system was one in which "it is easy to enter and spend much time, but with few exit possibilities. ${ }^{, 577}$ Over time, imprisonment as the main answer to crime fostered prison overpopulation, conflicts in penitentiaries, and the transformation of prisons in operational centers overseeing crime outside their walls ${ }^{578}$ By 2008 , the prison population had reached 18,814 inmates $(321 / 100,000)$, for a capacity of $8,227.579$

In response to the diagnostic the FMLN posed on the state security sector, the PNJSPC proposes to strengthen security governance, promote a greater access to justice and alternative conflict resolution means, and ensure compliance with norms and rules. Most of the proposed reforms focused on institutional structures and capabilities. The Funes administration claimed that these reforms, in coordination with the other pillars, would make El Salvador a safer country.

\subsubsection{Reform implementation}

\footnotetext{
${ }^{576}$ Ibid., 20.

${ }^{577}$ Ibid., 22.

${ }^{578}$ Ibid.

${ }^{579}$ Bureau of Democracy, Human Rights, and Labour, "El Salvador: 2008 Country Report on Human Rights Practices” (Washington, D.C.: U.S. Department of State, February 25, 2009), http://www.state.gov/j/drl/rls/hrrpt/2008/wha/119159.htm.
} 
There were some clear efforts early under Funes to respond to the diagnostic posed by the PNJSPC about the state of the security sector. The police academy and the PNC started to pivot toward a community policing approach. In 2009, Funes named Jaime Edwin Martínez as the new director of the ANSP. ${ }^{580}$ At the time, Martínez was a wellknown lawyer in public security and human rights circles in El Salvador. Prior to his nomination, he founded and directed from 1993 to 2005 the Centro de Estudios Penales de El Salvador (Centre for Criminal Studies - CEPES), a component of FESPAD. He was also the coordinator of the Supreme Court's juvenile justice unit from 2005 to 2009. Hence, Martínez brought to the police academy a vision and an experience in line with the government's stated priorities: prevention, reinsertion, and a community-oriented approach to policing and justice.

The ANSP curriculum moved from training based on military principles to a strong emphasis on community policing and citizen security. According to the ANSP's head of studies division, 18,000 police had been trained in accordance with the community policing principles by 2013. Developing a new policing culture and related practices represented an important challenge, however. It produced a generational clash, but the ANSP official suggested that the police force increasingly recognized that interventions by new recruits were sometimes more effective than those conducted by seasoned policemen. $^{581}$

\footnotetext{
${ }^{580}$ Martínez is a well-known lawyer in public security and human rights circles in El Salvador. Prior to his nomination, he founded and directed from 1993 to 2005 the Centro de Estudios Penales de El Salvador (Centre for Criminal Studies - CEPES), a component of FESPAD. From 2005 to 2009, he was the coordinator of the Supreme Court's juvenile justice unit.

${ }^{581}$ Interview with the Head of the Studies Division, ANSP, Comalapa, July 2013.
} 
In February 2010, the PNC adopted a five-year institutional strategic plan with two main objectives: develop a community policing doctrine promoting citizen participation, and restructure the PNC's to improve patrols and crime investigation. The plan raised a long list of weaknesses that allegedly hampered the PNC capacity to provide security, control crime, and address violence; it included technical issues (lack of standardized databases, infrastructures, and training) institutional problems (fragmented organization, little police investigation and intelligence capacities, limited operational budget, poor planning, and deficient performance evaluation), and weaknesses linked to personnel (lack of incentives, constant transfer, no career ladder for administrative staff, no retirement system, and loss of human capital). ${ }^{582}$

\subsubsection{The persistence of reactive and repressive strategies, 2009-2011}

Despite efforts by the FMLN to propose a new approach to public security and implement reforms, these changes did not eliminate the tendency of the Salvadoran State to rely on the armed forces as "the ultimate guarantor of public order." ${ }^{583}$ Repression and other "traditional patterns of state security provision" persisted despite change of government ${ }^{584}$ Facing a mounting public security crisis, the government quickly returned to reactive strategies and so-called "exceptional" measures that had become increasingly frequent in the last decade.

\footnotetext{
${ }^{582}$ PNC, "Plan Estratégico Institutional 2009-2014: Seguridad Y Tranquilidad, Con Participacion Social" (Policia Nacional Civil de El Salvador, February 2010), http://www.transparencia.pnc.gob.sv/portal/page/portal/transparencia/OIR/Mecanismo_participacion_ciuda dana/PEI_2009_-_2014.pdf; RESDAL, "El Salvador," in Public Security Index: Central America (Buenos Aires, 2013), 55, http://www.resdal.org/ing/libro-seg-2013/el-salvador-index-2013-ing.pdf.

${ }^{583}$ Susan Hoppert-Flämig, "A Salvadoran Turnaround? The FMLN's Response to Citizen Security Needs," in Repensando La Seguridad Desde Una Perspective Democatica Y de Derechos Humanos (54 International Congress of Americanists, Vienna, 2012), 1, http://www.academia.edu/2092714/A_Salvadoran_Turnaround_The_FMLNs_Response_to_Citizen_Securi ty_Needs. ${ }^{584}$ Ibid.
} 
In October 2009, Funes adopted a presidential decree to expand the role of the armed forces in public security. ${ }^{585}$ The decree authorized the conduct of joint patrols between the PNC and the armed forces in highly violent communities across the country. In practice however, the armed forces often patrolled alone. ${ }^{586}$ The government ordered the purge of prison personnel and the establishment of a new training program following on allegations of endemic corruption; in the meantime, the State chose to respond to the lack of prison personnel by deploying the armed forces in penitentiaries. In May 2010, the legislative assembly adopted another decree authorizing the deployment of 1,500 military personnel in the prison system. ${ }^{587}$

Gangs strongly reacted to the adoption of those decrees and public discussions surrounding the adoption of new anti-gang legislation. In the first half of 2010, at least 77 bus drivers were murdered. ${ }^{588}$ In June 2010 , La18 conducted an attack against a microbus in a municipality of the greater San Salvador, Mejicanos. The gang burned down the bus and its occupants. 17 people were killed, and 10 were severely injured. ${ }^{589}$ The night before, also in Mejicanos, the local gang opened fire on another bus, killing three people. The violence of those actions struck the public imagination, but they were

\footnotetext{
${ }^{585}$ Decreto No. 70/2009 de la Casa Presidencial, 30 October 2009. Available at : http://www.copades.com.sv/uploaded/content/article/1843872210.pdf

${ }^{586}$ Hoppert-Flämig, "A Salvadoran Turnaround?," 6.

${ }^{587}$ Decreto No. 371/2010 de la Asemblea Legislativa, 27 May 2010. Available at : http://www.diariooficial.gob.sv/diarios/do-2010/06-junio/17-06-2010.pdf

${ }^{588}$ Sonja Wolf, "Public Security Challenges for El Salvador's First Leftist Government," NACLA Report on the Americas, July 7, 2010, http://nacla.org/news/public-security-challenges-el-salvador\%E2\%80\%99sfirst-leftist-government.

${ }^{589}$ Ibid.; Diego Murcia, “15 Pasajeros Muertos En Ataque a Microbuses En Mejicanos,” Elfaro.net, February 21, 2010, http://www .elfaro.net/es/201006/noticias/1967/15-pasajeros-muertos-en-ataque-amicrobuses-en-Mejicanos.htm.
} 
not isolated incidents. Violence increased in most municipalities of the metropolitan zone of San Salvador in June, and again in August 2010. ${ }^{590}$

In September 2010, under pressure from the public and the ARENA opposition, the government adopted the Ley de Proscripción de Maras, Pandillas, Agrupaciones, Asociaciones y Organizaciones de Naturaleza Criminal (Maras, Gangs, Groups, Associations and Organizations Of Criminal Nature Prohibition Act - LPM). ${ }^{591}$ The new legislation criminalized gang membership and introduced more severe penalties. Furthermore, the government refused to engage in any dialogue with imprisoned gang members and their family, despite requests presented through advocacy groups such as FESPAD. ${ }^{592}$

Despite the hard line against gangs, the government and especially Manuel Melgar, the Minister of Public Security, faced strong criticisms in regards to their incapacity to control crime and violence in the country. Mounting pressure against the government led to the resignation of Melgar in November 2011. Funes then reshuffled his security cabinet. He named David Munguía Payés, a retired general who was Minister of National Defence, as the new Minister of Public Security. Eduardo Linares was then forced to resign as the head of the Organismo de Inteligencia del Estado (State Intelligence

\footnotetext{
${ }^{590}$ Observatorio metropolitano para la prevencion de la violencia, "Analisis de Delitos En El AMSS 2010" (Observatorio metropolitano para la prevencion de la violencia, 2011).

${ }^{591}$ Decreto No. 458/2010 de la Asamblea Legislativa, Ley de Proscripción de Maras, Pandillas, Agrupaciones, Asociaciones y Organizaciones de Naturaleza Criminal, 10 September 2010. Available at http://www .asamblea.gob.sv/eparlamento/indice-legislativo/buscador-de-documentos-legislativos/ley-deproscripcion-de-maras-pandillas-agrupaciones-asociaciones-y-organizaciones-de-naturaleza-criminal ${ }^{592}$ Interview with the with the coordinator for the program on citizen security and criminal justice, FESPAD, San Salvador, September 2013. Also see Hoppert-Flämig, “A Salvadoran Turnaround?,” 6.
} 
Agency - OIE). Distrusted by the president, Linares was replaced by Ricardo Perdomo and Colonel Simón Molina Montoya, both close to Munguía Payés. ${ }^{593}$

In January 2012, the president named Francisco Salinas, the Deputy Minister of National Defence and another retired general, as the new director of the police force. Upon his nomination, Salinas made important changes inside the PNC leadership, naming Commissioner Howard Cotto as the deputy director of public security. Commissioner Hugo García Funes, was put in charge of the Western region, the stronghold of the Texis Cartel, despite being investigated internally for links with drug traffickers. ${ }^{594}$ Zaira Navas, Inspector General of the PNC, was forced to resign. These changes pushed aside individuals close to the traditional structure of the FMLN, suggesting tensions between the party and the president. ${ }^{595}$ Even more interestingly, the overhaul put in place individuals long associated to Munguía Payés. Upon his nomination, the new minister of public security promised to reduce homicides by 30 percent in the first 12 months of his appointment. ${ }^{596}$

In sum, the FMLN government of Mauricio Funes promoted a new approach to security and justice in El Salvador after its election in March 2009. However, early discussions of reforms were quickly put aside in the face of mounting popular and political pressure to address violence and crime in the country. ${ }^{597}$ Reactive decisions took

\footnotetext{
${ }^{593}$ Sonja Wolf, "Policing Crime in El Salvador," NACLA Report on the Americas 45, no. 1 (2012): $43-54$. 594 Ibid.

${ }^{595}$ Mauricio Funes, journalist turned politician, was selected as the FMLN presidential candidate as a way to moderate the image of the party and appeal to a broader electorate. He represented a departure form the heavy ideological baggage of the party. However, through his term, tensions between the party and Funes became visible, as they did not share the same vision on many policy matters, including security.

${ }^{596}$ Gabriel Labrador and José Luis Sanz, "Viceministro de Seguridad, Henry Campos, Renuncia Al Cargo," Elfaro.net, January 31, 2012, http://www .elfaro.net/es/201201/noticias/7422/Viceministro-de-SeguridadHenry-Campos-renuncia-al-cargo.htm.

${ }^{597}$ Hoppert-Flämig, “A Salvadoran Turnaround?,” 6.
} 
precedence over a more progressive public security agenda. Yet, despite a series of repressive measures, homicides remained extremely high through the first half of Funes' mandate, reaching almost 65 and 70 homicides per 100,000 in 2010 and 2011 respectively, and suggesting a lower level of public order in the national POR.

\subsection{The Salvadoran public order regime, 2009-2011}

Until 2012, the Salvadoran POR (table 7) remained similar to the post-Mano Dura regime presented in the previous chapter. The State faced powerful non-state actors able and willing to use harsh violence against state security forces and the Salvadoran population to reaffirm their authority and power over their turf. Furthermore, the ineffectiveness of state formal public ordering only justified in the eyes of many recourse to informal means, from human rights abuses and corruption to extrajudicial violence.

Table 7 Public order regime, El Salvador, 2009-2011

\begin{tabular}{|l|l|l|}
\hline & Informal Public Ordering & Formal Public Ordering \\
\hline Non-state Actors & Gangs & \\
\hline State Actors & $\begin{array}{l}\text { Extrajudicial violence and } \\
\text { human rights abuses by the } \\
\text { police and military }\end{array}$ & $\begin{array}{l}\text { Police forces } \\
\text { Armed forces } \\
\text { Intelligence services } \\
\text { Justice system }\end{array}$ \\
\hline
\end{tabular}

\subsubsection{State public ordering}

\subsubsection{Formal public ordering}

\subsection{PNC}


Counting on 22,055 police agents, the PNC had 3.54 police officers per 1,000 inhabitants in 2012, in line with international standards. ${ }^{598}$ However, these numbers appeared insufficient to curb violence and control crime. As discussed earlier, reforms were implemented to transform the PNC culture and practices, but results were disappointing and remained localized. I discussed at length this transformation in the training provided by the ANSP with public security experts and representatives of the civil society. Overall, the new curriculum was well received by the trainees, suggesting that "the cadets of the police academy in the last three, four years are going to be a [...] different generation of police agents. ${ }^{, 599}$ However, some experts had serious doubts about learning sustainability and feared that once new recruits were deployed with older officers, former practices would prevail. Indeed, police officers often felt that "citizen security [was restricting] public security." ${ }^{600}$

Inside the PNC itself, there was significant resistance at the leadership level to community policing, a key element of the new approach. ${ }^{601}$ Many police officers considered community policing as an activity rather than as a philosophy. As a result, there was not momentum to support the diffusion of community policing principles through the institution. Some divisions were willing to adopt these principles while other refused to do so ${ }^{602} \mathrm{As}$ a result, prevention and community policing would depend on who managed the police delegation. Some territorial delegations, such as the delegation for Soyapango and Ilopango in the greater San Salvador, were particularly opposed to

\footnotetext{
598 The RESDAL report presents the PNC numbers. RESDAL, "El Salvador," 55.

${ }^{599}$ Interview with the Head of the Studies Division, ANSP, Comalapa, July 2013.

${ }^{600}$ Interview with the Head of the Studies Division, ANSP, Comalapa, July 2013.

${ }^{601}$ Interview with an employee of the Citizen Security and Criminal Justice Program, FESPAD, San Salvador, September 2013.

${ }^{602}$ Interview with the Head of the Studies Division, ANSP, Comalapa, July 2013.
} 
community policing, opting for a repressive approach sometimes problematic with regards to human rights. ${ }^{603}$ In other delegations, community-policing units were formed, but they did not have an assigned budget to support outreach activities, limiting their ability to have a significant impact on police-community relations. ${ }^{604}$ When it comes to specialized units, such as the anti-gang task force, their members received the training but they did not apply the community policing philosophy in their intervention. They captured and intimidated, a vision only reinforced by joint patrols and operations with military personnel.

\subsection{Armed forces}

From 2009, despite the reforms proposed by the FMLN during the electoral campaign, El Salvador witnessed a militarization of public security in the name of crime and violence control. Between 2008 and 2009 alone, the number of military personnel involved in public security surged by 330 percent. Then, from 2009 to 2010 , their participation increased again by 40 percent. ${ }^{605}$ Considering that the armed forces had a strength of approximately 33,000 during that period, it signifies that 20 percent of the armed forces were assigned to public security. The participation of military troops in public security declined in 2012, once the gang truce was brokered, but increased again drastically after the deal collapse.

\footnotetext{
${ }^{603}$ Interview with the coordinator for the program on citizen security and criminal justice, FESPAD, San Salvador, September 2013.

${ }^{604}$ Field research notes, San Salvador, June 2015.

${ }^{605}$ IUDOP, “La Situación de La Seguridad Y La Justicia 2009-2014: Entre Expectativas de Cambio, Mano Dura Militar Y Treguas Pandilleras," xxx.
} 
Table 8 Military personnel involved in public security, 2008-2014

\begin{tabular}{|l|l|l|l|l|l|l|l|}
\hline Year & 2008 & 2009 & 2010 & 2011 & 2012 & 2013 & 2014 \\
\hline $\begin{array}{l}\text { Military } \\
\text { personnel }\end{array}$ & 1,975 & 6,500 & 8,200 & 8,200 & 6,300 & 6,200 & 11,200 \\
\hline
\end{tabular}

Source: Ministerio de Defensa Nacional (2008-2012), Presidencia de la Republica (2013 and 2014).

Resource increase also affected the MDN's budget. Between 2009 and 2011, the

defence budget assigned to the support to public security went from US\$10,575,000 to

US\$23,713,772, which represents an increase of 124 percent. ${ }^{606}$ In parallel, the overall defense budget went from approximately US\$ 115 millions in 2009 to almost US\$ 146 millions in 2011 (current US\$). ${ }^{607}$ The security budget for that period also increased from US\$ 322 millions to US\$ 379 millions. As pointed out by RESDAL in the 2012 Public Security Index: "although in overall terms the percentage of security spending in GDP has a fairly stable curve over the past decade, the security budget has grown proportionally more than double that of the State budget." 608

Besides, the nomination of former members of the armed forces in positions overseeing civilian security institutions reinforced the perception that the armed forces were increasingly involved in the management of public security and domestic matters. For many experts from the human rights community and the traditional base of the FMLN, these nominations challenged the spirit of the constitution and the peace accords, which actively sought to limit the interference of the military institution in domestic

\footnotetext{
${ }^{606}$ Ibid., 93.

${ }^{607}$ See RESDAL, "El Salvador,” 52.

${ }^{608}$ Ibid.
} 
affairs, and presented a threat to the progress made through the democratization process. ${ }^{609}$

\subsection{Penitentiaries}

According to Susan Hoppert-Flämig, "corruption among staff, overpopulation and the large-scale coordination of extortions by inmates [brought] the prison system near to a collapse." ${ }^{610}$ The recurrent revolts of imprisoned gang members with lethal consequences also fuelled the public impression that the State was not in control of the prisons ${ }^{611}$ In response to these issues and as pointed out earlier, the legislative assembly authorized the deployment of 1,500 military personnel in some of the most dangerous prisons of the country to deal with corruption, to curb violence, and eliminate illicit activities inside the penitentiaries. ${ }^{612}$ The presence of military personnel in prisons did re-establish order, but it also opened the door to abuses, which I describe later on.

In sum, despite initial efforts to address issues within the security and justice sector and adopt a more progressive approach to security provision, the State quickly returned to reactive and repressive policies to respond to armed crime and violence. The reorganization of the security cabinet around individuals close to Munguía Payés and sometimes at odd with the FMLN suggests that there was likely little political will on the part of Funes and his cabinet to implement the reforms elaborated by the party prior to the 2009 election.

\footnotetext{
${ }^{609}$ Interview with the director, IUDOP, San Salvador, June 2015. See also the discussion by Mike Allison, "A Changing of the Guard in El Salvador," Al Jazeera, November 29, 2001, http://www .aljazeera.com/indepth/opinion/2011/11/20111128111359866466.html.

${ }^{610}$ Hoppert-Flämig, “A Salvadoran Turnaround?,” 7.

${ }^{611}$ Ibid.

${ }^{612}$ Decreto No. 371/2010 de la Asemblea Legislativa, 27 May 2010. Available at : http://www.diariooficial.gob.sv/diarios/do-2010/06-junio/17-06-2010.pdf
} 


\subsubsection{Informal public ordering}

The militarization of the security and justice sector and the early abandonment of the PNJSPC facilitated the persistence of state informal public ordering. The constant security crisis and the implementation of harsh security measures allowed for human rights abuses and extrajudicial violence against gang members and people associated to them. According to the Procuraduría para la Defensa de los Derechos Humanos (Ombudsman Office for the Defence of Human Rights - PDDH), the number of complaints for human rights violations against members of the armed forces increased significantly from 2009 to 2012 . While 57 complaints were filled in 2009 , it rose to 215 in 2010,373 in 2011 , and 237 in $2012 .^{613}$

In the penitentiaries, the new military leadership adopted new rules overseeing visits, opening the way to abuses. For example, it was decided that visitors should dress in white to visit inmates in prison to facilitate their identification. This rule applied not only to regular clothes, but also to female underwear. As a consequence, it promoted the stigmatisation of gangs' families in the street and in public transportations, and facilitated sexual abuses against female visitors during body search prior to entering prison facilities. ${ }^{614}$ Indeed, in 2010, the Inter-American Commission on Human Rights reported abusive and arbitrary search of female visitors and inmates by military personnel:

It was reported that the searches done of women who come to visit inmates have included inappropriate vaginal and anal searches. These are applied in general to all women, without distinction, including pregnant women and senior citizens,

\footnotetext{
${ }^{613}$ IUDOP, “La Situación de La Seguridad Y La Justicia 2009-2014: Entre Expectativas de Cambio, Mano Dura Militar Y Treguas Pandilleras," 95.

${ }^{614}$ Interview with the coordinator for the program on citizen security and criminal justice, FESPAD, San Salvador, September 2013.
} 
and refusing to submit to such searches results in that family member's being denied permission to visit. ${ }^{615}$

Abuses of force and power were not limited to the prisons, however. According to IUDOP's report on the public security situation in 2009-2014: "Members of the PNC are also repeatedly accused of human rights, physical integrity, and freedom violations, especially against residents of vulnerable areas. However, [...] the police do it in a more covert way, while the members of the armed forces commit abuses openly." ${ }^{16}$ Despite the severe diagnosis posed by the FMLN in its public security policy, weak internal control mechanisms and political interference continued to foster impunity. The Inspectoría General de la Policía Nacional Civil (The PNC General Inspectorate IGPNC) remained under-resourced and vulnerable to political interference. In an interview, a senior advisor from the MJSP stated: "the most recent attempts at cleaning the ranks or the police, undertaken by the general inspector Saira Navas, were blocked politically and there was no criminal charge follow-up. [...] There is a political network that is interested in maintaining certain patterns of weakness within the police." ${ }^{\prime 617}$ This is illustrated by the nomination of Commissioner García Funes in a key leadership position despite the fact that he was under investigation for criminal activities. Thus, while some formal control mechanisms were in place through the Inspectorate General of the PNC and the PDDH to deal with abuses and other violations committed by members of the PNC, there seemed to be little political will inside the organization and within the State to

\footnotetext{
${ }^{615}$ Inter-American Commission on Human Rights, "Preliminary Observations in the Visit to El Salvador by the Office of the Rapporteur on the Rights of Persons Deprived of Liberty. Annex to Press Release 104/10" (Organization of American States, October 20, 2010), 4, http://www .cidh.oas.org/Comunicados/English/2010/ANNEX\%20104-10.pdf.
} 
ensure that internal control was effective. Consequently, tolerance for abusive behaviours and impunity contributed to the endurance of state informal public ordering.

\subsubsection{Non-state public ordering}

\subsubsection{Street gangs}

\subsection{Local turf and influence over public order}

In 2011, the PNC evaluated the number of gang members in the country at $28,130 .^{618}$ As a point of comparison, there were 12,500 gang members with criminal records in 2008 according again to the PNC. ${ }^{619}$ It is important to put these numbers in perspective however, as gang membership estimates tend to vary drastically over time and based on different sources. Indeed, as pointed out in the previous chapter, estimates in 2006 varied from 10,000 to $40,000{ }^{620}$ While these numbers include incarcerated members and those with criminal records, they do not account for individuals who support or cooperate with gangs. ${ }^{621}$ Nonetheless, it is safe to assume that gangs remained a significant actor in the Salvadoran POR, both in terms of number and influence on public ordering.

\footnotetext{
${ }^{616}$ IUDOP, “La Situación de La Seguridad y La Justicia 2009-2014: Entre Expectativas de Cambio, Mano Dura Militar Y Treguas Pandilleras," 96.

${ }^{617}$ Interview with a ministerial advisor, Ministry of Justice and Public Security, San Salvador, July 2013.

${ }^{618}$ Douglas Gonzalez, “28 Mil 130 Pandilleros Registra La Policía En El 2011,” Periódico Digital La Página, December 21, 2011, http://www .lapagina.com.sv/nacionales/60115/2011/12/21/28-mil-130pandilleros-registra-la-policia-en-el-2011.

${ }^{619}$ Ministerio de Justicia y Seguridad Publica, "Política Nacional de Justicia, Seguridad Publica Y Convivencia," 17.

${ }^{620}$ U.S. Overseas Security Advisory Council, "El Salvador: 2006 Crime and Safety Report.”

${ }^{621}$ It is important to note that gangs are covert, turf-oriented organizations that are loosely structured despite a national leadership. Local cliques are composed of core members, both leaders and foot soldiers, who commit most of the violence. Other individuals revolve around core members, starting with messengers and sentinels, then their girlfriends and families, and finally individuals living in communities where cliques are based and concentrate most of their activities. In response to repression and the criminalization of gang membership under Mano Dura, gangs changed how they dressed and stopped bearing visible tattoos: "today it is difficult to know who is a gang member and who is not. [This transformation] allows gangs to engage in other activities that are much more difficult to witness and
} 
During the first years of the Funes administration, gangs continued to rely mostly on extortion as a source of revenue. Maintaining protection rackets and extortion justified the need for local cliques to use violence to protect their turf and enforce specific rules regulating communities. Most people I interviewed agreed that gangs had some form of territorial control and/or influence over certain neighbourhoods and sectors of activity, such as public transportation. The extent of their control and how it manifested itself varied over time and space. Yet, as pointed out by a program coordinator for UNDP, their control was not total. It was rather based on their capacity to use violence to enforce specific rules. The certainty with which these rules were imposed affected their position as sources of authority: "they have to make sure they can enforce [these rules]. Their enforcement is based on the [...] application of their own internal rules, which is [...] the threat of violence." ${ }^{622}$

Cliques used violence to assert territorial claims against rival and impose their authority over the local population. An investigative journalist explained different patterns when asked whether gangs have authority over communities: "[some gangs] use terrible violence against their community and have even managed to banish some of its inhabitants, for example in the case of Lourdes. [...] In Lourdes, gang members are not all from the community, they come [from elsewhere]." ${ }^{623}$ Elsewhere, violence tends to be lower, especially when cliques' claims are established and recognized. For example, in the community of Montreal in Mejicanos: "[gang members] were born and raised in the

access." Interview with project coordinator - democratic governance and security, UNDP, San Salvador, July 2013.

${ }^{622}$ Interview with a project coordinator - democratic governance and security, United Nations Development Program, San Salvador, July 2013.

${ }^{623}$ Interview with an investigative journalist, San Salvador, September 2013. 
community, or at least the leaders. [Some] gang members are from elsewhere but they submitted themselves to [...] the leaders. [...] [The clique] merged with the community to such a degree that they now work together." ${ }^{624}$

These anecdotes suggest that when gangs would enter a community, they would rely more heavily on violence to establish a new order. Once that order was recognized, constant coercion became less necessary. Ultimately, once it is well-established "a clique does not bother people who live in its territory, people know them, they are immersed; gangs bother people from territories [controlled by rival cliques]. ${ }^{625}$

Inside their turf, rules enforced by cliques targeted specific activities, such as businesses, as well as access and free circulation in communities they controlled. Local cliques often dictated where and if community members could attend school, which bus they could take, and where they could run their daily errands. For instance, I was told that in Ilopango, people living in MS-13 turfs would shop for groceries at the Super Selectos, while those living in La18 territory would go to La Despensa de Don Juan, now Maxi Despensa. Trespassing those rules could have deadly consequences. Again in Ilopango, teenagers attending the professional school disappeared and were allegedly murdered by the MS-13 in 2009 and 2010. The school is located in the community of Santa Lucia, which was then controlled by a MS-13 clique. According to the director of the school, these students were not gang members per se, but they lived in communities controlled by the La18 and were therefore associated to a rival clique. ${ }^{626}$ By going to school in a

\footnotetext{
${ }^{624}$ Interview with an investigative journalist, San Salvador, September 2013.

${ }^{625}$ Interview with the school director, Instituto Santa Lucia, Ilopango, September 2013.

${ }^{626}$ Interview with the school director, Instituto Santa Lucia, Ilopango, September 2013.
} 
MS-13 turf, these teenagers trespassed the authority of the local gang and were therefore punished for doing so.

Yet, if local gang control was certainly extensive, it was in no way total. Cliques managed relations with different actors present in the communities, from the PNC and other state agencies to local government, community leaders, NGOs, and even foreign donors. Nonetheless, powerful cliques could influence who access their turf, including the PNC:

There are communities in the country where gangs have a presence that intimidates the population and [...] the police. I am not saying that the police cannot enter these communities; these are not free territories or territories controlled exclusively by the gangs. These are communities where the police have to enter well armed and with great care because the gangs have operations there. The gangs do not confront directly the police, they only face the police in situations where they were caught committing a crime. ${ }^{627}$

In another interview, a senior advisor from the MJSP described how cliques can limit the State's access to certain communities: "The Health Minister has denounced how her ministry cannot implement a vaccination plan because gangs would not allow government employees to enter certain places. ${ }^{628}$ Similarly, a UNDP project coordinator described how the gangs affected the implementation of a housing project in a community with a strong La18 presence: "[w]hen we entered the community, we were constantly under the permanent curfew of the gang. This community was a stronghold of La18." In other cases, NGOs negotiated their entry through local stakeholders who are

\footnotetext{
${ }^{627}$ Interview with a consultant on violence reduction and prevention for USAID, San Salvador, July 2013.

${ }^{628}$ Interview with a ministerial advisor, Ministry of Justice and Public Security, San Salvador, July 2013.
} 
trusted by the local clique. In Ilopango, FESPAD entered communities controlled by rival cliques through community leaders who acted as gatekeepers. ${ }^{629}$ Hence, cliques can influence who access communities and how they do so, affecting service provision and development initiatives. During my fieldwork, I would also wait to obtain the direct authorization of gang leaders or the support of community leaders before entering certain neighbourhoods. NGO workers well aware of local dynamics and trusted by gang member also helped me navigate the sometimes complex power structures of these communities.

All in all, gangs continued to exert control over local communities, shaping the daily life of people living in their turf through coercion or its threat. Repression under Funes influenced the conduct of gangs' activities and their use of violence, but like Mano Dura, it did produce the expected result: a reduction in crime and violence.

\subsection{Consequences of state repression on gangs' activities}

New repressive measures implemented by the Funes administration had three main consequences on gangs' behaviours. First, it reshaped how gangs would conduct extortion. Second, gangs relied more heavily on extreme and coordinated violence as a signalling tool against Salvadoran state authorities. Third, constant repressive presence in low-income popular neighbourhoods of the country's main urban cities contributed to a migratory movement of some cliques towards the countryside.

\footnotetext{
${ }^{629}$ Interview with an employee of the Citizen Security and Criminal Justice Program, FESPAD, September 2013.
} 
In the second half of the 2000s, prison came to play a key role in the administration of extortion activities and protection rackets. ${ }^{630}$ Extortion was managed through cellphones from behind bars, until the reinforcement of penitentiary security measures in $2009 .{ }^{631}$ As a consequence, extortion practices evolved. Aspiring members, often very young, started presenting extortion threats in person. ${ }^{632}$ Based on discussions with Salvadoran business owners, members of the local clique would show up to their business and asked for $l a$ renta, a fixed amount to be paid on a regular basis. In some cases, there was space for negotiation, while in other cases, refusal to comply would be met by threats of violence and their execution. As pointed out by Sonja Wolf, by 2011, "shopkeepers, market vendors, teachers, and sex workers operating in gang territories all need[ed] to make regular payments, but public transport companies [were] particularly affected., ${ }^{963}$

Besides, evidence suggests that the MS-13 and La18 used coercion and violence to signal their influence and power. The gruesome attacks against buses in June 2010 described earlier are key examples of signals sent by gangs to the government in response to the adoption of repressive measures. Over the same period, the MS-13 and the La18 also demonstrated they could join efforts to oppose the Salvadoran government. In

\footnotetext{
${ }^{630}$ Sonja Wolf, "The Maras - an Escalating Problem in El Salvador," Latin American Bureau, January 24, 2012, http://lab.org.uk/the-maras-an-escalating-problem-in-el-salvador; Marroquín, "Pandillas Cambian Forma de Extorsionar a Sus Víctimas," El Diario de Hoy, December 15, 2011, $\mathrm{http} / /$ archivo.elsalvador. com $/ \mathrm{mwedh} / \mathrm{aspnet} / \mathrm{chkDispositivo}$. aspx ?idart=6475206\&idcat=47859\&t=nota\& $\mathrm{m}=$ aHR0cDovL2FyY2hpdm8uZW xzYWx2YWRvci5jb20vbXdlZGgvbm90YS9ub3RhX2NvbXBsZXRhL mFzcD9pZENhdD00Nzg1OSZpZEFydD02NDc1MjA2\&sin=NOWEBCACHE.

${ }^{631}$ Wolf, "The Maras - an Escalating Problem in El Salvador."

${ }^{632}$ Gonzalez, "28 Mil 130 Pandilleros Registra La Policía En El 2011."

${ }^{633}$ Wolf, "The Maras - an Escalating Problem in El Salvador."
} 
September 2010, they organized “a three-day strike that paralyzed El Salvador's transport system in response to new [anti-gang] legislation., ${ }^{634}$

Finally, in response to an increased repressive state presence in urban communities where gangs were particularly active, some cliques started moving to the countryside in areas where the State was less present, or at least less disruptive: "crime does not stop, it runs. ${ }^{" 635}$ Yet, moving to new communities meant that cliques would use violence to affirm their authority over their new turf, and sometimes forcing entire families to abandon their home. ${ }^{636}$ Following the patterns described above, cliques entering new communities tended to rely heavily on violence to affirm their control, establish new rules, and implement new protection rackets. Consequently, families were sometimes forced to move out of their home and leave their community ${ }^{637}$

In sum, through the first years of Funes presidency and until the 2012 truce, gangs remained significant coercive actors in the Salvadoran POR. Maintaining income from extortion meant using violence to enforce specific rules that would dictate the daily of the peoples. In some communities, the clique's authority was recognized enough to reduce the necessity to use violence. Yet, their capacity to use violence remained their primary mean through which they asserted their authority, protected and expanded their turfs, and opposed the State's security institutions and legislative process. Gangs' coercive power, the Salvadoran State's enduring reliance on reactive and repressive strategies to oppose

\footnotetext{
${ }^{634}$ Bruneau, "Pandillas and Security in Central America," 160-61; Ribando Seelke, "Gangs in Central America," 5.

${ }^{635}$ Interview with a state modernization specialist, Inter-American Development Bank, San Salvador, June 2013.

${ }^{636}$ IUDOP, "La Situación de La Seguridad Y La Justicia 2009-2014: Entre Expectativas de Cambio, Mano Dura Militar Y Treguas Pandilleras," 12.

${ }^{637}$ Cristian Meléndez, "Pandilleros Provocan Que Familias Dejen Colonia," La Prensa Gráfica, June 21, 2013, http://www.laprensagrafica.com/pandilleros-provocan--que-familias-dejen-colonia.
} 
them, and their consequences on public order fed a vicious circle where confrontation only created more violence.

\subsubsection{Overall level of public order}

From 2009 to the March 2012 truce, the Salvadoran POR produced a low level of public order, as suggested by the increase in the homicide rate (figure 3). Despite initial efforts by the FMLN to design a new strategy towards public security and crime control, high homicides rates, popular perception of state ineffectiveness, and violent upsurges caused by the gangs justified a returned towards reactive and repressive strategies. In a context of constant public security crisis, institutional reforms, prevention, and community policing were put aside. A direct causation cannot be established between repression and violence since the increase in the national homicide rate occurred prior to the deployment of military personnel to support public security. However, the militarization of public security through 2009 and 2010 did not have the expected effect on public order; homicide numbers remained at similar levels through 2010 and 2011.

Repression by the State created important tensions between its security institutions and the gangs who were able to claim some control over the production of public order inside the POR. Gangs reacted strongly to repression, flexing muscle when necessary. Extortion being highly dependent on turf control, strong repression in one community would only pushed gangs to strike back or to move toward spaces where the State was less present. Establishing new territorial control as a result would translate in a higher reliance on violence to impose new rules that had consequences for the people living in

those spaces. In other words, gangs responded to repression through territorial expansion and migration, change in extortion strategy, and more violence. 
Nonetheless, the State's response to gangs and the gruesome situation in the prisons of the country was popular with Salvadorans. According to the 2011 Latinobarómetro, 35 percent of surveyed Salvadorans had a lot or some confidence in the PNC between 2009 and $2011 .^{638}$ In comparison, more than 55 percent of Salvadorans had a lot or some confidence in the armed forces over the same period. ${ }^{639}$ NGOs workers reported that people often felt safer with the military presence, ${ }^{640}$ which can be intriguing considering that the military forces and paramilitary organizations were the main perpetrators of violence against civilians during the civil war. ${ }^{641}$ Yet, "citizens tend to distinguish the military's past abuses against innocent civilians from today's harsh treatment of suspected criminals." ${ }^{642}$ Given that the PNC was perceived as weak and ineffective, in addition to being distrusted by the population, the involvement of the armed forces in public security matters was considered a step in the right direction.

In sum, the momentum created for institutional reforms with the election of the FMLN in 2009 was quickly lost. Some limited reforms were initiated inside the prison system, the ANSP, and the PNC. However, pressure for immediate results and rising homicide rates provoked a return to repression, despite the previous failure of Mano Dura measures. As under previous administrations, short term political gains were preferred to a long-term strategy based on prevention and more respectful of human rights. Pressures to address crime diverted the Funes administration from its initial reform platform,

\footnotetext{
${ }^{638}$ Corporación Latinobarómetro, “Latinobarómetro 2011” (Corporación Latinobarómetro, 2011).

${ }^{639}$ Ibid.

${ }^{640}$ Interview with an employee of the Citizen Security and Criminal Justice Program, FESPAD, September 2013.

${ }^{641}$ UN Security Council, "From Madness to Hope: The 12-Year War in El Salvador: Report of the Commission on the Truth for El Salvador."

${ }^{642}$ Wolf, "Policing Crime in El Salvador."
} 
justifying the perpetuation of reactive policies, impunity, chronic institutional weakness, and the lack of oversight on the activities of security institutions. Reforming institutions under fire quickly became impossible, as calls for crime reduction were the only driving force in the security cabinet.

\subsection{The gang truce: reducing violence to stabilize the POR}

In March 2012, homicides dropped abruptly to levels unseen since the end of the civil war. Days later, El Faro, the online investigative newspaper, reported that the MS-13 and La18 gangs had brokered a truce with the help of Raúl Mijango, former congressman and guerrilla fighter, and Monsigor Fabio Colindres, the head bishop of the Salvadoran armed forces. ${ }^{643}$ The effect on homicides was immediate. The national murder rate dropped by approximately 50 percent overnight and remained at that level for approximately 15 months. Homicides began to increase again in the summer of 2013, but they only reached pre-truce levels after the presidential election of March 2014. In 2011, the national homicide rate was 70.1 per 100,000 population. In comparison, in 2012 and 2013, the national murder rate dropped to 41.2 and 39.4, according to the PNC. Figures 4 and 5 show the impact of the truce on monthly and annual homicide numbers.

${ }^{643}$ Martínez et al., "Gobierno Negoció Con Pandillas Reducción de Homicidios.” 
Figure 4 Monthly homicide numbers, El Salvador, 2011/11-2014/12

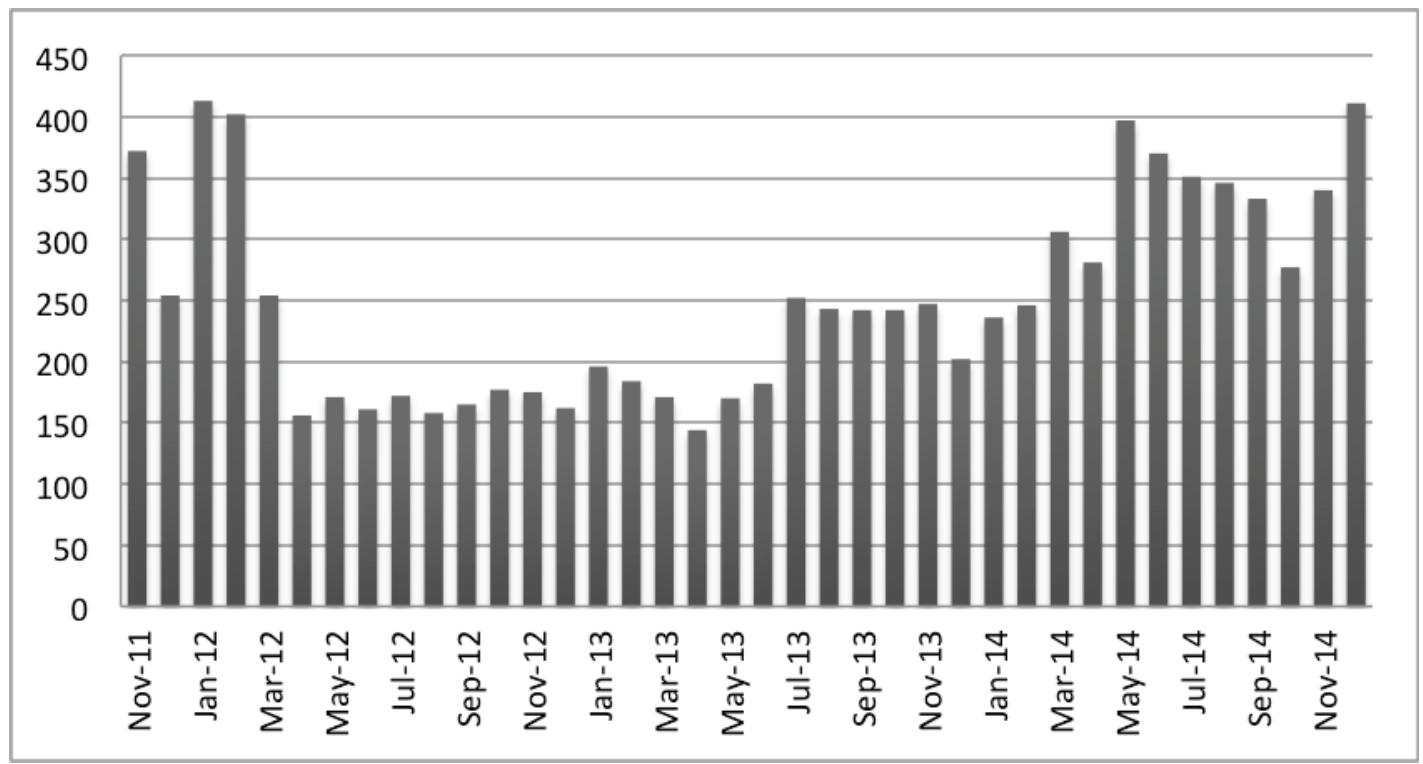

Source: Policía Nacional Civil.

Figure 5 Annual homicide numbers, El Salvador, 2009-2014

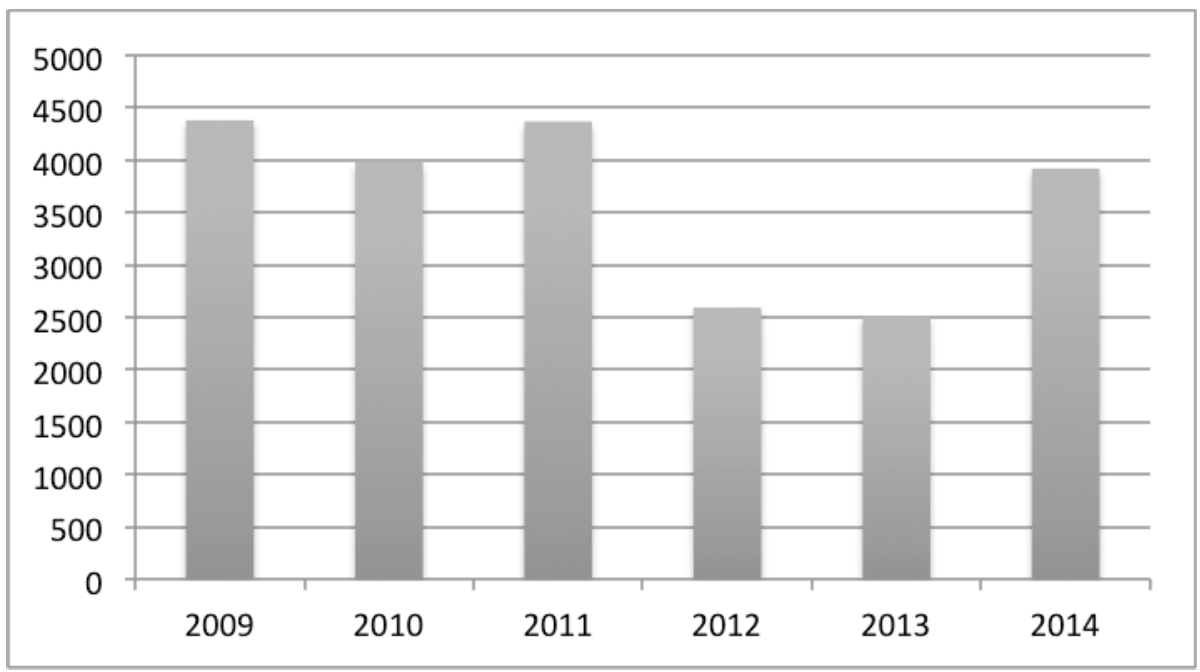

Source: Policía Nacional Civil

In this section, I discuss the process that led to the deal and the role of the State in the conclusion of the truce, the content of the agreement, and how it unfolded in the months that followed. The rest of the chapter will then describe the impact of the truce on the structure of the POR and the resulting level of public order.

\subsubsection{Negotiating and maintaining the ceasefire}




\subsubsection{The gang truce}

Evidence of early dialogue between state authorities and incarcerated gang members can be traced back to Saca's presidency. As prison population grew, gangs started to organize themselves in penitentiaries to formulate demands about their living conditions. For instance, in 2005, thousands of inmates launched a hunger strike to protest against torture, food shortages, and limits over family visits. ${ }^{644}$ In 2009, the MS-13 and the La18 organized joint protests in different prisons across the country and with their family members to demand better incarceration conditions. ${ }^{645}$ The action demonstrated their ability to coordinate, advance a common agenda, and present a united front against the State. ${ }^{646}$

On the State's side, the idea of a dialogue with imprisoned gang leaders to reduce homicides came early under the Funes government. According to Steven Dudley, codirector of Insight Crime, the Funes administration approached religious figures known to work closely with the gangs to establish a conversation and test the waters about a potential truce ${ }^{647}$ However, popular and political pressure for harsh response to gang violence quickly pushed aside the idea of dialogue in favour of repression. The idea of a truce remerged when the government concluded that reactive policies prioritizing repression would not reduce violence. The constant crisis provoked by ramping homicides and gangs' demonstration of force posed an important challenge for the

\footnotetext{
${ }^{644}$ Freedom House, “Country Report: El Salvador 2008,” Freedom House, 2008, https://freedomhouse.org/report/freedom-world/2008/el-salvador.

${ }^{645}$ Freedom House, “Country Report 2010: El Salvador,” Freedom House, 2010, https://freedomhouse.org/report/freedom-world/2010/el-salvador.

${ }^{646}$ Interview with a researcher, FESPAD/Interpeace, San Salvador, September 2013.

${ }^{647}$ Steven Dudley, "The El Salvador Gang Truce and the Church: What Was the Role of the Catholic Church?," CLALS Working Papers Series (Washington, D.C.: Center for Latin American \& Latino Studies, May 5, 2013), 13.
} 
implementation of the FMLN's public security strategy. Constantly under fire, state security institutions were unable to tackle violence and carry out other more progressive aspects of the PNJSPC, including institutional reforms. Change in leadership in the security cabinet realigned the State's strategy: Munguía Payés promised in November 2011 to reduce homicides by 30 percent within a year. Homicide reduction became the core objective of the government, a prerequisite for the implementation of the PNJSPC.

Discussions with gang leaders in the high-security prison of Zacatecoluca appear to have begun sometimes in 2011, led by Raúl Mijango, long-term consultant for Munguía Payés. ${ }^{648}$ Mijango later affirmed that he only sought to talk with gang leaders in January 2012, following a plan established with the minister ${ }^{649}$ The Catholic Church was brought into the process later on. The involvement of Monsignor Fabio Colindres, head bishop of the armed forces and also a close acquaintance of the new minister, sought first and foremost to legitimize the truce in the eyes of the most conservative groups in the Salvadoran society. ${ }^{650}$ However, his participation created tensions within the Salvadoran clergy, as some of its most influential members did not support the idea of a gang truce. ${ }^{651}$ Despite the involvement of two negotiators closed to Munguía Payés, the role of the State in the process was initially unclear. As weeks and months passed by however, it became more and more evident that the State had facilitated the conclusion of the accord. ${ }^{652}$ The State played a key role in providing bargaining chips against a reduction in

\footnotetext{
${ }^{648}$ Interview with an investigative journalist, San Salvador, September 2013. See also Ibid., 11.

${ }^{649}$ Martinez and Sanz, "La Nueva Verdad Sobre La Tregua Entre Pandillas."

${ }^{650}$ Ibid.

${ }^{651}$ For a detailed discussion of the Church's role in the truce, see Dudley, "The El Salvador Gang Truce and the Church: What Was the Role of the Catholic Church?"

${ }^{652}$ In May 2016, the new Attorney General Douglas Meléndez ordered the arrest of over 20 current and former state officials, including the main negotiator Raul Mijango, who face charges of illicit association for participating in the truce process. Alberto Arce, "El Salvador Throws Out Gang Truce and Officials
} 
homicides perpetrated by the country's two main gangs. ${ }^{653}$ In exchange, the State agreed to move 30 gang leaders from Zacatecoluca to regular jails, increase visiting rights for family members, and provide access to televisions. ${ }^{654}$ Furthermore, military personnel were withdrawn from all prisons, without any prior consultation with prison management. ${ }^{655}$ Hence, reduction in homicides came in exchange for improved detention conditions for gangs.

Immediately following the transfer of gang leaders, local cliques received the order to stop killings. These orders were respected, since gang members feared punishment. ${ }^{656}$ Homicides dropped by more than 50 percent the day following the beginning of the truce, ${ }^{657}$ and the reduction was maintained over the following months. Despite early discussions the truce was never expanded to include a suspension of extortion activities. $^{658}$

\subsubsection{The second phase: the peace zones}

Who Put It in Place," The New York Times, May 20, 2016, http://www.nytimes.com/2016/05/21/world/americas/el-salvador-throws-out-gang-truce-and-officials-whoput-it-in-place.html.

${ }^{653}$ Martinez and Sanz, "La Nueva Verdad Sobre La Tregua Entre Pandillas”; Cruz and Durán-Martínez, "Hiding Violence to Deal with the State Criminal Pacts in El Salvador and Medellin."

${ }^{654}$ Randal C. Archibold, "In El Salvador, Violence Falls Amid a Gang Truce," The New York Times, August 27, 2012, http://www.nytimes.com/2012/08/28/world/americas/in-el-salvador-gang-truce-bringstenuous-peace.html; José Sanz and Carlos Martinez, "Exviceministro de Seguridad Negoció En Persona Con Líderes Pandilleros," El Faro, July 27, 2013, http://www.salanegra.elfaro.net/es/201307/cronicas/12785/.

${ }^{655}$ According to an interview conducted by Susan Hoppert-Flämig, the director of one of the largest penitentiaries was informed about the decision only two days before the military force withdrew. See Hoppert-Flämig, "A Salvadoran Turnaround?," 7.

${ }^{656}$ Martínez et al., "Gobierno Negoció Con Pandillas Reducción de Homicidios.” ${ }^{657}$ Ibid.

${ }^{658}$ Dudley, "The El Salvador Gang Truce and the Church: What Was the Role of the Catholic Church?”; Jessica Ávalos and Ricardo Flores, "Gobierno Facilita a Iglesia Negociación Por Extorsiones," La Prensa Gráfica, April 12, 2012, http://www .laprensagrafica.com/el-salvador/judicial/257650-gobierno-facilita-aiglesia-negociacion-por-extorsiones.html. 
On November 22, 2012, Munguía Payés held a press conference to assess his first year as Minister of Public Security and highlight how he had respected his promise to reduce homicides ${ }^{659}$ During the same press conference, standing next to PNC officials, the mediator Raúl Mijango announced the second phase of the truce: the establishment of municipalities free of violence. ${ }^{600}$ Inside these peace zones, gangs would hand in their weapons and commit to a zero crime policy, including homicides, extortion, and kidnappings, while the PNC would cease to conduct large-scale and overnight anti-gang operations. ${ }^{661}$ Social and economic reintegration plans would also be put in place for gang members to open up economic and social alternatives to crime.

Negotiations surrounding the creation of the first peace zone in Ilopango - a municipality of the metropolitan zone of San Salvador - started in November 2012. Mijango and Douglas Moreno, then vice-Minister of Public Security in charge of violence prevention, were directly involved in Ilopango's talks with gang spokesmen and local representatives. Mungia Payés himself signed the peace accord, alongside the MS13 and La18 leaders for Ilopango. ${ }^{662}$ The dialogue between the MJSP, the local government, and the gangs lasted beyond the signature of the initial agreement in January 2013. For instance, in April, Moreno sat down with the spokesmen of the MS-13 and

\footnotetext{
${ }^{659}$ Carmen Rodriguez and Israel Serrano, "Municipios Santuarios" definirán Segunda Fase de Tregua Entre Pandillas," Diario digital de noticias de El Salvador, La Pagina, (November 23, 2012), http://www.lapagina.com.sv/nacionales/74210/2012/11/23/Municipios-santuarios-definiran-segunda-fasede-tregua-entre-pandillas.

${ }^{660}$ Ibid.

${ }^{661}$ Hannah Stone, "Next Phase of Salvador Gang Truce: Peace Zones," Insight Crime, November 23, 2012, http://www.insightcrime.org/news-briefs/next-phase-salvador-gang-truce-peace-zones.

${ }^{662}$ Gloria Morán, "Pandilleros de Ilopango Firman Acta Por La Paz," ContraPunto Diario El Salvador, January 22, 2013, http://www.contrapunto.com.sv/archivo2016/violencia/pandilleros-de-ilopango-firmanacta-por-la-paz.
} 
La18 in Ilopango to obtain the gangs' authorization for public sanitary and education services to access communities they controlled. ${ }^{663}$

\subsubsection{The role of the State}

Despite the involvement of members of his government described above, President Funes never fully revealed the extent of the role his administration played in brokering and sustaining the truce. He initially denied any involvement of his administration and even refused to acknowledge the effect of the deal on homicides. However, as results lasted over months, he gradually recognized its impact on homicides. In 2013, he stated: "the truce is not a government strategy; it was signed between the gangs and what the government did was to facilitate the truce based on its results." ${ }^{964}$ Tensions between different components of the security cabinet likely contributed to this position. In April 2013, the Attorney General, Luis Martinez, publically qualified the truce as "hypocritical," revealing that gang members continued to extort and kill the Salvadoran population, including in peace zones ${ }^{665}$ During a trip to the U.S. to promote the results of the truce with donors, Funes responded that he could hardly see how the truce was hypocritical since it had resulted in a significant reduction of homicides nation-wide. ${ }^{666} \mathrm{In}$ May 2013, Funes announced a series of social and economic reinsertion programs. During the press conference, he stated that his government needed to answer gangs'

\footnotetext{
${ }^{663}$ Sanz and Martinez, "Exviceministro de Seguridad Negoció En Persona Con Líderes Pandilleros."

${ }^{664}$ CNN Español, "Mauricio Funes: 'Tregua de Las Maras Entró En Crisis, Pero No Se Ha Roto,"” CNNEspañol.com, December 9, 2013, http://cnnespanol.cnn.com/2013/12/09/mauricio-funes-tregua-de-lasmaras-entro-en-crisis-pero-no-se-ha-roto/.

${ }^{665}$ Jessel Santos, “Fiscal: La Tregua Es Una 'negociación Hipócrita,’” La Prensa Gráfica, April 18, 2013 , http://www.laprensagrafica.com/fiscal--la-tregua-es-una--negociacion-hipocrita- .

${ }^{666}$ Lopez, "Funes Responde Al Fiscal General Que Llamó 'hipócrita’ el Pacto Entre Maras En El Salvador."
} 
demands to ensure the sustainability of the truce. ${ }^{67}$ Nonetheless, Funes rejected systematically any accusation that its government was negotiating with gang members.

The truce lost its momentum in May 2013 after a change of guard in the security cabinet. Munguía Payés and Salinas, the PNC director, were forced to resign after the constitutional chamber of the Supreme Court ruled that their nomination violated the spirit of the constitution, as former members of the armed forces cannot hold civilian positions in government. ${ }^{668} \mathrm{~A}$ few weeks later, vice-minister Moreno also resigned, days before his wife filed a complaint for domestic violence. ${ }^{669}$ Funes named Ricardo Perdomo as Minister of Public Security. During his first press conference, he claimed that the truce was not a strategy of the government, but rather a social phenomenon. ${ }^{670}$ Departing from his predecessor who had made homicide reduction his priority, Perdomo announced that he would tackle extortion and target cliques who were associated to narco traffic. These changes also coincided with the beginning of the presidential campaign. None of the political party supported the truce process. The FMLN distanced itself from Funes, and ARENA adopted "there is no truce with crime" $" 671$ as it main slogan. From the summer of 2013, homicide numbers started to rise again.

In the next section, through the discussion of the resulting POR, I illustrate how the truce managed to improve the level of public order produced by the regime, despite its

\footnotetext{
${ }^{667}$ Carlos Martinez, “Gobierno Da Un Paso Para Asumir Responsabilidad Sobre La Tregua,” El Faro, April 22, 2013, http://www .elfaro.net/es/201304/noticias/11796/.

${ }^{668}$ Gloria Flores, “Munguía Payés Califica de ‘humillante’ Resolución de CSJ," La Prensa Gráfica, May 21, 2013, http://www.laprensagrafica.com/munguia-payes-califica-de--humillante--resolucion-de-csj.

${ }^{669}$ Jessel Santos and Gabriela Melara, "Douglas Moreno Ante Juez Por Violencia Intrafamiliar," La Prensa Gráfica, June 10, 2013, http://www.laprensagrafica.com/douglas-moreno-ante-juez-por-violenciaintrafamiliar.

${ }^{670}$ Jessel Santos, "Nuevo Ministro de Seguridad Desliga a Gobierno de Tregua," La Prensa Gráfica, May 30, 2013, http://www.laprensagrafica.com/nuevo-ministro-de-seguridad-desliga-a-gobierno-de-tregua. 671 "No hay tregua con la deliquencia"
} 
pluralism. I also highlight how tensions within the government and between the State's central authorities and local governments proved to be a destabilizing force in the POR.

\subsection{Resulting public order regime}

The truce had a significant impact on the structure of the Salvadoran POR and the level of public order it produced. The implementation of the deal required the initial retraction of the State's presence in the regime, mainly in prisons and peace zones. For the gangs, the truce formalised to a certain degree their authority and recognized their ability to dictate behaviours through coercion. By establishing relatively clear rules for coercive actors, the process reduced disruption caused by confrontations between coercive actors, state and non-state. The truce fell apart when it was clear that the government would no longer support the process and fulfill its side of the deal.

\subsubsection{State public ordering}

\subsubsection{Formal public ordering}

The truce implied the momentary contraction of state coercive actors inside the POR and the abandonment of repressive strategies. Immediately following the conclusion of the deal, the armed forces withdrew from prisons. Then, in November 2012, the truce mediators asked without success for the repeal of the Gang Prohibition Act. ${ }^{672}$ In the months that followed, Munguía Payés also ordered the cancellation of large police operations against gangs. ${ }^{673}$ Finally, during the negotiations surrounding the

\footnotetext{
${ }^{672}$ James Bargent, "El Salvador Truce Mediators Call for Repeal of Anti-Gang Law," Insight Crime, November 28, 2012, http://www.insightcrime.org/news-briefs/el-salvador-gang-truce-mediators-repealanti-gang-law.

${ }^{673}$ James Bargent, "Ex-Minister Accused of Interfering in El Salvador Anti-Gang Ops," Insight Crime, June 28, 2013, http://www.insightcrime.org/news-briefs/ex-minister-accused-of-interfering-in-anti-gangops-in-el-salvador; Suchit Chávez, "FGR Acusa a Exministro de Seguridad de Entorpecer Captura de
} 
implementation of the second phase of the truce, it was agreed that local police delegations would not longer conduct large anti-gang swipes in municipalities free of violence.

Yet, the withdrawal of the State's repressive means did not meant the complete removal of the State. According to the ANSP's head of studies, "[the truce enabled] the police to penetrate certain sectors without playing the role of the bad guy. Discussions already show that in municipalities free of violence where gangs do not commit crime, the community police can start to work and identify needs." ${ }^{974}$ Furthermore, during my field research, I was able to notice the participation of Ilopango's police chief in the management of the peace zone in Ilopango, where he would participate to events and meetings alongside the gangs' spokesmen, the mayor, community leaders, and religious figures.

This was true not only for the police, but also for other sectors of the State that could not previously enter some communities controlled by gangs. Indeed, after the implementation of the peace accords in Ilopango, a series of employment and reinsertion programs were put in place in communities with high gang presence: hen farms, bakeries, and metal workshops. Funded by the central government and international donors, these initiatives were key to ensuring the sustainability of local peace processes. However, promised funds by the MJSP often did not turn into concrete budgets and programs. ${ }^{675} \mathrm{In}$ the case of Ilopango, I was able to witness that reinsertion projects were limited and only

Pandilleros," La Prensa Gráfica, June 27, 2013, http://www.laprensagrafica.com/fgr-acusa-a-exministrode-seguridad-de-entorpecer-captura-de-pandilleros.

${ }^{674}$ Interview with the Head of the Studies Division, ANSP, Comalapa, July 2013.

${ }^{675}$ Jessel Santos and Ricardo Flores, "Sin Claridad Fondos Para 'santuarios,"” La Prensa Gráfica, January 22, 2013, http://www.laprensagrafica.com/sin-claridad-fondos-para--santuarios- . 
involved a few dozen of gang members in a municipalities where estimates of gang membership vary between several hundreds to several thousands. For instance, in the case of the hen farm, workers told me the farm employed approximately 20 people from the MS-13, in addition to a couple of women from the community who would pluck the chicken before selling them to local shops.

After the dismissal of Munguía Payés in May 2013, tensions between the different components of the state security apparatus became increasingly visible and police operations against gangs increased. According to a MJSP senior advisor, the Ministry tried to create conditions that foster employment and development at the community level, but the PNC would come in and stop projects, destroying the trust built between the State and local stakeholders ${ }^{676} \mathrm{He}$ added: "the truce, since it is not an official political process with control mechanisms, allows for these distortions. ${ }^{9677}$ To illustrate this point, in May 2013, anti-gangs units arrested several La18 members while they were working in a steel workshop, a reinsertion project in the community of Novena Etapa in Ilopango. ${ }^{678}$ The clique leader was arrested as well, and the project closed shortly after. The NGO who ran this project denounced the arrests to the MJSP, claiming that these teenagers were part of a reinsertion project. They were told that "[the police is not from the delegation, they are from the elite troops. Often, the [local police] chiefs do no know what is going to happen, nor is the mayor is expecting those interventions." ${ }^{979}$

\footnotetext{
${ }^{676}$ Interview with a ministerial advisor, Ministry of Justice and Public Security, San Salvador, July 2013.

${ }^{677} \mathrm{Id}$.

${ }^{678}$ Author's field research notes, May 2013.

${ }^{679}$ Interview with an employee of the Citizen Security and Criminal Justice Program, FESPAD, September 2013.
} 
Similarly, in September 2013 and in the context of an international conference on the truce organised in San Salvador, some of the peace zones organised visits for foreign donors in their municipalities. OAS and EU representatives visited Ilopango, where the MS-13 and La18 had both organized events to showcase the results of the local peace process. Accompanying the delegation, I observed that while the La18 event was relatively low-key, the MS-13 brought in gang members from around the country by bus, and some members of the senior national leadership were also present. As the presentation by the MS-13 unveiled, more and more members of the PNC anti-gang unit appeared. As soon as foreign officials left the event, hooded policemen stopped a young gang member, provoking anger and panic among the couple of hundreds of gang members present. Cliques ran away through small alleys, like schools of fish, to leave by bus. The PNC stopped those buses as they left Ilopango, controlling everybody in them. These actions had been carried out by the central command of the PNC, without any knowledge of the local police or Ilopango's mayor, as I was later able to confirm. ${ }^{680}$

\subsubsection{Informal public ordering}

There are few reports attesting of widespread informal public ordering carried out by state security forces during the truce. However, a recent investigation by the Attorney General's Office for corruption and arm trafficking during the truce suggest that there were more to the truce than what has been made public. The State may have provided financial and material incentives to the gangs to maintain the truce after it was initially brokered. Elias Hernandez, the mayor of Apopa, one of the peace zones, is accused of

\footnotetext{
${ }^{680}$ Interview with the mayor of Ilopango, Ilopango, September 2013.
} 
having paid off gang leaders in his municipality, up to $\$ 5,000$ to $\$ 10,000$ per individual, to prevent killings. He is also said to have covered costs associated with gas, phone, and funerals for gangs. ${ }^{681}$ According to a religious leader close to the negotiation process in one of the peace zones, "[gangs] are now immune to the law, the political authorities use them in exchange for money or gifts, but they continue to extort, to win." ${ }^{982}$

Munguía Payés was also put under investigation regarding arm trafficking in early 2014, shortly after the end of the truce. ${ }^{683}$ In April 2014, the head of the PNC, Rigoberto Pleités, announced that gang members had attacked police officers on patrol in the municipality of Quezaltepeque, using military tactics and heavy weaponry. ${ }^{684} \mathrm{He}$ claimed that this attack had required some form of military training and that those weapons were only used by the armed forces.

Those elements point to a lack of transparency in the truce process and suggest that there was more to the deal than the information made public. It implies that the State, or actors in positions of power inside it, used covert means to keep the truce in place. Paying off gangs and providing them weapons and training may have contributed to the stabilization of the POR and to the level of order it produced during the truce, but it also reinforced gangs, which backfired once the deal failed.

\subsubsection{Non-state public ordering}

\subsubsection{Street gangs}

\footnotetext{
${ }^{681}$ Suchit Chavez, "Moreno: tregua Fue Politica de Estado de Funes,” La Prensa Gráfica, June 17, 2016.

${ }^{682}$ Interview with a religious leader, Ilopango, September 2013.

${ }^{683}$ Seth Robbins, “El Salvador's Military: Arms Dealer to the Maras?," Insight Crime, June 16, 2014, http://www.insightcrime.org/news-analysis/el-salvadors-military-arms-dealer-to-the-maras.

${ }^{684}$ Jessel Santos and Marcos Salguero, "PNC: Pandillas Con Tácticas Militares," La Prensa Gráfica, April

8, 2014, http://www.laprensagrafica.com/2014/04/08/pnc-pandillas-con-tacticas-militares.
} 
The consensus among most experts and participants interviewed during and after the truce is that the process reinforced the gangs' organisational structure and formalised their authority inside the POR. First, the truce facilitated vertical command and control by sending leaders back to regular prisons from where they could more easily oversee actions of cliques across the country. The fact that homicides stopped overnight in March 2012 strongly supports the idea that the incarcerated leadership can control cliques on the streets.

Furthermore, similarly to traditional agreements between warring factions, the truce fixed territorial lines. In a context where the State was no longer targeting them constantly through large anti-gangs operations, it enabled gangs to consolidate their territorial control and move more freely: "The truce is only a façade because the only thing that has been accomplished is that [gangs] have grown, they move freely." ${ }^{685}$ Similarly, practitioners in charge of development programs in communities with high gang presence and where peace zones were established considered that gangs could now move and recruit members more easily: "where there was no gang before the truce, they are now present," ${ }^{686}$ and "they move freely, recruiting youth." 687

Second, the truce formalised to some degree gangs' authority, especially in the peace zones, as they joined negotiation processes with state and state-sponsored actors. This dialogue enabled the MS-13 and La18 to articulate their demands and present a clear agenda. According to an IDB official, "this tregua is giving [the gangs] a lot of political legitimacy [...] they are perceived like a local authority [...] the problem is that their

\footnotetext{
${ }^{685}$ Interview with a religious leader, Ilopango, September 2013.

${ }^{686}$ Interview with the coordinator for the program on citizen security and criminal justice, FESPAD, San Salvador, September 2013.

${ }^{687}$ Interview with a religious leader, Ilopango, September 2013.
} 
local authority is becoming a national authority and a political authority." ${ }^{688}$ For instance, after the truce showed signs of weakness in the summer of 2013 and following the visit of foreign donors to peace zones described earlier, the MS-13 and the La18, with other gangs not officially part to the truce, presented a press release in which they offered their support to any presidential candidate who would support the truce and the local peace processes, highlighting their political weight. ${ }^{689}$ According to the PNC, gang membership reached 60,000 during the truce. ${ }^{690}$ When I was conducting field research, the word on the street was that when considering the number of people associated or collaborating with gangs, the number climbs to 600,000 , in a country of 6 millions.

Following the implementation of peace zones, gangs managed to influence who would benefit from development initiatives. USAID funded the development of local youth community centers, the rehabilitation of public spaces, and vocation training programs such as the Programa de Apoyo Temporal al Ingreso (Temporary Access Support Program - PATI). USAID worked with the MJSP and municipal authorities to implement these projects. Through its local partners, USAID also worked with religious figures, community leaders, and the civil society, but refused to work directly with gangs due to their criminal nature. PATI was developed and implemented in 2013 in six municipalities free of violence as part of the truce process. The program's objective was to provide additional income - US\$100 per month - to vulnerable households to get

\footnotetext{
${ }^{688}$ Interview with a state modernization specialist, Inter-American Development Bank, San Salvador, June 2013.

${ }^{689}$ The original press release is no longer available online. However, a transcription is available at: Roberto Valencia, "Decimocuarto Comunicado de Las Pandillas," Crónicas Guanacas, September 20, 2013, http://cronicasguanacas.blogspot.com/2013/09/decimocuerto-comunicado-de-las-pandillas.html.

${ }^{690}$ William Meléndez, "La Cifra Que Nos Sale Es 60,000 Pandilleros En La Mitad de Municipios," La Prensa Gráfica, May 1, 2012, http://www.laprensagrafica.com/el-salvador/judicial/260717-la-cifra-quenos-sale-es-60000-pandilleros-en-la-mitad-de-municipios.html.
} 
vocational training and gain access to the job market. The program was initially supposed to target youth at risk and single mothers. However, during its implementation in certain municipalities, bargaining between the municipal authorities, gang leaders who were participating in local peace processes, and other community representatives (police commanders, religious figures, community leaders) enabled gang members to benefit from the program. In April 2013, Douglas Moreno, then vice-Minister of Public Security, announced that the program would target 400 persons in Ilopango, including 200 gang members - 100 from each gang. However, once PATI was implemented, all participating households were related to local cliques, and the program funded directly 750 gang members. ${ }^{691}$ Cliques leaders even approved and signed off the finalised list of participants. National newspapers quickly uncovered that PATI was funding local gang members. ${ }^{692}$ As a result of gang participation, USAID shut down the program in September 2013. An employee of the USAID's country office indicated in an interview that PATI was a complete failure, specifically because the gangs had recuperated it to their own profit. ${ }^{693}$

This is not unique to USAID, however. An expert from the IDB states that violence prevention programs "are not intended to work for the gangs; they are intended to work for the youth and guys that are almost gang members." ${ }^{\prime 694}$ However, donors cannot always supervise or limit who access local projects. As pointed out by a senior researcher from

${ }^{691}$ Cristian Meléndez, “750 Pandilleros Dentro Del Programa PATI,” La Prensa Grafica, July 22, 2013, http://www.laprensagrafica.com/750-pandilleros-dentro-del-programa-pati.

${ }^{692}$ El Faro, "Editorial: PATI Para Pandilleros," Elfaro.net, August 26, 2013, http://www .elfaro.net/es/201308/opinion/13096/.

${ }^{693}$ Interview with a program coordinator, USAID, San Salvador, June 3, 2015.

${ }^{694}$ Interview with a state modernization specialist, Inter-American Development Bank, San Salvador, June 2013. 
the Fundación Salvadoreña para El Desarrollo Economico y Social (Salvadoran Foundation for Economic and Social Development - FUSADES), a lot of programs are considered preventive, but they included gang members. ${ }^{695}$ These programs called themselves "preventive" to get funding, but they cannot stop gang members from participating to their activities. Segregating gang members, considering their number and their influence in at-risk communities targeted, is hardly feasible.

A local researcher however considered that the formalization of their authority created responsibilities for the gangs, and limited their capacity to use violence indiscriminately. ${ }^{696}$ For instance, the community of Las Cañas was deemed the most dangerous community in Ilopango. Divided between rival cliques of the MS-13 and La18, access to services such as the school and the mill was limited to people living in the turf of the clique controlling these installations. The only school in the community was situated in MS-13 turf, and parents of children living in the La18 territory would refuse to send their kids to school, fearing that they would be mistaken for members of the rival clique. Once the peace process was established, rival cliques met with some of the school instructors to discuss access to the school for all the children living in Las Cañas. ${ }^{697}$ The agreement was made public, announced by the local cliques' leaders to the population. They guaranteed that access would be granted to all, and that if any problem occurred, they would deal with it personally. Yet, fewer children than expected initially

\footnotetext{
695 Interview with a senior researcher, FUSADES, May 2015.

${ }^{696}$ Interview with a researcher, FESPAD/Interpeace, San Salvador, September 2013.

${ }^{697}$ Carlos Martínez and José Luis Sanz, “III. Democráticos Homies,” Elfaro.net, April 7, 2014, http://www.salanegra.elfaro.net/es/201404/cronicas/15198/III-Democráticos-homies.htm.
} 
went back to school, which may well be a sign trust that towards rival cliques and the deal remained low. ${ }^{698}$

Nonetheless, another example shows how the process provided rules that enabled trust building between parties. In September 2013, while I was conducting research in Ilopango, five members of La18 were killed in broad daylight in the municipality. ${ }^{699}$ The MS-13 and La18 spokesmen were sitting in a meeting in the mayor's office when the killings occurred. The MS-13 denied immediately any implication in the murders, and La18 rejected the hypothesis of MS-13 responsibility. In communities controlled by the MS-13, many inhabitants shared with me rumours of retaliation in the days that followed the assassinations. Parents refused to send their children to school and avoided public spaces. Yet, no reprisal against the MS-13 occurred. ${ }^{700}$ Prior to the local peace process, those murders would have likely started a retaliation war between the rival cliques.

In sum, the truce strengthened the relative position of the gangs in the POR, as the process formalized to some extent their authority. In peace zones especially, gangs gained prestige, influence, and visibility, standing next to state officials and local members of the PNC. Furthermore, the truce reduced turf wars between cliques, as violence and homicides were the main ways through which competition occurred. In some communities, it is safe to say that the local peace processes created channels of communication between clique leaders, local authorities, and the population to peacefully manage and resolve conflict.

\subsubsection{Overall level of public order}

\footnotetext{
${ }^{698}$ Martinez, "Ilopango Contra Su Sombra."

${ }^{699}$ Carlos Martinez and José Luis Sanz, “Tiembla La Tregua En Ilopango,” El Faro, September 7, 2013, http://www.elfaro.net/es/201309/noticias/13231/.

${ }^{700}$ Author's field research notes, September 2013.
} 
The gang truce improved the level of public order in the Salvadoran POR. The immediate and sustained reduction in homicides over 15 months certainly had a positive impact on the daily life of Salvadorans, especially in low-income neighbourhoods with high gang presence. However, the truce did not address all forms of crime. First, the truce was criticized first and foremost because it did not target extortion, the main source of revenue for gangs. As noted earlier, there was some discussion to expand the truce to extortion in the early days of the process. ${ }^{701}$ However, gangs refused to include these activities in the deal unless alternative sources of income were made available. ${ }^{702}$ Once those programs were put in place, the State had lost interest in the process, with coming elections.

Furthermore, the number of disappearances reported to the police increased sharply during the truce. According to the PNC Intelligence Center, the number of reported disappearances rose every year starting in 2009. In 2012, reported disappearances reached 1,682 . This number than dropped to 1,140 , but remained higher than during the first three years of the Funes administration. ${ }^{703}$ Some experts have argued that an increased number of disappearances could explain part of the decline in the homicide count, an argument supported by the discovery of mass graves in different municipalities across the country. ${ }^{704}$ However, the lack of robust data on the cause of disappearances and

\footnotetext{
701 Ávalos and Flores, "Gobierno Facilita a Iglesia Negociación Por Extorsiones."

${ }^{702}$ Miriam Wells, “'Rising Extortion' Signals Trouble For El Salvador's Gang Truce,” Insight Crime, March 18, 2013, http://www.insightcrime.org/news-briefs/rising-extortions-trouble-salvador-gang-truce. ${ }^{703}$ Data from the PNC's Centro de Inteligencia Policial (Police Intelligence Center) presented in IUDOP, "La Situación de La Seguridad Y La Justicia 2009-2014: Entre Expectativas de Cambio, Mano Dura Militar Y Treguas Pandilleras," 24.

${ }^{704}$ Steven Dudley, "Mass Graves Burying the Truth about El Salvador Gang Truce," Insight Crime, January 1, 2014, http://www.insightcrime.org/news-analysis/homicides-mass-graves-and-truth-about-el-salvadorgang-truce.
} 
limited investigation in most cases makes it difficult to assume that most disappearances were unreported homicides.

Finally, if the truce reduced homicides and improved the daily life of people in the peace zones, reducing violence and facilitating to some extent movements between rival territories, such successes failed to impress national public opinion. Days before the first anniversary of the truce, a survey by La Prensa Gráfica, one of the country's top newspapers, revealed that 55 percent of Salvadorans had a negative opinion of the process, and only one out of three Salvadorans recognized the truce had some benefits, despite the clear reduction in homicides. ${ }^{705}$ There was little support for reinsertion $(6.6$ percent), attesting of the gangs' bad public image ${ }^{706}$ However and interestingly enough, according to Latino Barómetro, the percentage of people who considered crime and public security the most important problem in El Salvador dropped during the truce. ${ }^{707}$ In 2011, 40 percent of respondents considered that crime and public security were the most pressing issue facing the government. In 2013, that percentage dropped to 20 percent and increased sharply in 2015 to 42.5 percent, once the truce was over.

Overall, the truce did improve the level of public order in the POR by reducing armed confrontation between coercive actors and by formalising to some degree the gangs' authority. However, lack of transparency regarding what was actually put on the table and the role of the State in the process undermined its sustainability over time. When it became clear that supporting the truce would involve significant political costs, all

\footnotetext{
${ }^{705}$ Edwin Segura, “Tregua, Entre Dudas,” La Prensa Gráfica, March 7, 2013, http://www.laprensagrafica.com/Tregua--entre-dudas.

${ }^{706}$ Ibid.

${ }^{707}$ Latinobarómetro, "Problema Más Importante En El País, El Salvador 2004-2015,” Latinobarómetro Database, 2015, http://www.latinobarometro.org/latOnline.jsp.
} 
presidential candidates walked away from the process. Following the election of the FMLN candidate Salvador Sanchez Céren, March 2014 was the most violent month in the previous two years and confirmed the end of the truce.

\subsection{Conclusion}

The FMLN came to power in 2009 with a new public security strategy that emphasized the necessity to reform security institution to improve their effectiveness, accountability, and transparency. The policy also proposed a more comprehensive approach to public security, combining prevention, repression, and reinsertion. However, the arrival of Funes in power also coincided with a peak in homicides that generated strong demands for an assertive response from the political opposition and the Salvadoran population. As a result, Funes and his government adopted a series of reactive measures, going against their initial strategy. Repression proved once more to be an unfit strategy to reduce crime and violence.

The truce embodied a complete change in strategy under the new minister Munguía Payés. Transforming security institutions was not possible under crisis; hence, solving the crisis became the priority. The truce stabilised the POR and revealed the relative importance of state and non-state coercive actors in the production of public order. It highlighted the gangs' authority in communities across the country and their ability to influence violence and public order. Furthermore, while the process first relied on the end of large-scale operations against gangs and therefore a withdrawal of the State, it later created opportunity for the State to expand its authority in the POR, especially in spaces previously largely controlled by non-state coercive actors. Finally, the truce demonstrates 
that negotiated agreements between coercive actors can help manage violence and produce a higher level of public order in a pluralist POR.

While reforms in the security sector are often seen as a way to reduce armed crime and violence, violence reduction became here a prerequisite for reforms. By controlling violence in the regime, the truce presented a key opportunity for the State to implement long-overdue reforms in the security sector. However, lack of transparency, uncertainty surrounding the promises that were made on each side of the table, and the electoral calendar all undermined the sustainability of the process. As a result, by the end of the truce, the gangs were stronger than ever. Once the deal collapsed, cliques were able to intensify extortion and use military weapons and tactics against state security institutions. Nonetheless, in former peace zones, violence remained lower than in other communities with high gang presence. ${ }^{708}$

\footnotetext{
${ }^{708}$ Roberto Valencia, “La Tregua Redefinío El Mapa de Asesinatos En El Salvador,” El Faro, March 9, 2015, http://www.salanegra.elfaro.net/es/201503/cronicas/16490/La-Tregua-redefini\%C3\%B3-el-mapa-deasesinatos-de-El-Salvador.htm.
} 


\section{Chapter: Making Sense of SSR in Fragile States - The Contribution}

\section{of the Public Order Regime Framework}

Security sector reform emerged in the 1990s as a promising concept, bringing together concerns for state security and the safety of its citizenry. Donors rapidly reached a consensus on the importance of SSR to promote an effective, democratic, and wellgoverned security sector, enabling security and development. This consensus resulted in the elaboration of detailed policy frameworks and blueprints to guide operations in fragile states and post-conflict settings. Yet, evidence suggests that SSR too often failed to fulfill its core objectives: make people feel safer, while controlling crime and violence.

Why is it so? The policy and the academic literature have offered a wide range of explanations detailed in chapter one, from lack of resources, commitment problems, and coordination issues, to deficit in local ownership and lack of understanding for the political economy of fragile states and post-conflict societies. Yet, these arguments fall short explaining why, despite 10 years of international presence, Haiti seems to be stuck in a volatile suboptimal equilibrium where positive security and stability seem elusive; and why, despite strong, capable security institutions, El Salvador is unable to reduce crime and violence, and looks each day a little bit more like a country at war against its own citizenry.

In this dissertation, I have argued that SSR often fails to control violence and improve public order because it usually only targets the State's formal security and justice institutions. By remaining state-centric, SSR only addresses part of the public order regimes of fragile states, which are composed of multiple state and non-state coercive actors that produce public order through more or less formal means. By expanding the 
State's capacity to claim control over the means of violence without much concern for the rest of the POR, SSR disrupts the existing regime and is unlikely to improve public order. In fact, when non-state actors have a strong incentive to maintain some control over the means of violence inside the regime, SSR is likely to lead to tensions and create conflicts. As a result, state-centric SSR can contribute to, rather than address, insecurity and violence.

In this concluding chapter, I first provide a summary of the case studies and their key findings. I highlight how conceiving fragile states as pluralist public order regimes, and thus considering the complete set of mechanisms through which security is managed in these polities, helps to better understand how SSR affects public order, and how different strategies toward non-state actors and informal public ordering can mitigate the disruptive impact of these reforms. Third, I draw some policy implications, highlighting the need for a more pragmatic approach to SSR in contexts where state security institutions only constitute one provider of security and order among many others, and proposing an incremental approach to increase the sustainability of security sector reform. I conclude by discussing future avenues of research to test more systematically the propositions at the core of this project.

\subsection{Making sense of SSR in fragile states: Haiti and EI Salvador}

SSR fell short of its promises in Haiti and El Salvador. In each country, the reform process ultimately did not deliver the promised stability, security, and justice. Nonetheless, in both cases, SSR strategies varied over time, and some approaches have been more successful than others at mitigating disruption and violence, providing insights on how SSR negative impact on public order can be reduced. 


\subsubsection{Haiti}

When MINUSTAH deployed to Haiti in 2004 to stabilize the country after four years of deep polarization and growing instability under President Aristide, the State lacked virtually any capacity and authority. State security forces were only one element of a complex constellation of armed actors who used coercion to advance more or less private interests, resulting in a highly volatile and dysfunctional public order regime. The UN and other international donors conceived SSR, one of MINUSTAH's main priorities, as the key strategy through which the State would extend its authority through Haiti. Stabilizing the country was conceived as an essential prerequisite to these reforms, and thus became a concurrent priority for international stakeholders and the government of René Préval, elected in early 2006. Consequently, while reform plans targeting the national police and the justice sector were designed and adopted, Préval introduced the "disarm or die" strategy to deal with disruptive armed groups in Port-au-Prince. If the name of the strategy suggests a narrowly confrontational approach, non-state armed actors were in fact offered a choice: they could join local peace-building programs, or they would be forcefully disarmed and neutralized. In other words, under this mixed strategy, disruptive coercive actors engaging in informal public ordering could decide to take part in the formalisation process targeting local authority and governance, or they risked being eliminated from the POR. Following the implementation of that strategy, which directly engaged non-state armed groups, the security situation improved significantly in Port-au-Prince and its surroundings between 2007 and 2009. The relative capacity of state institutions to provide formal public ordering and security increased, and the influence of disruptive non-state actors and informal public ordering was reduced. 
Yet, the January 2010 earthquake derailed this advance, destabilizing the regime and reducing the level of public order it produced as a result. The natural disaster undermined formal public ordering and enabled non-state actors to play a larger role in public ordering, especially in poor neighbourhoods of Port-au-Prince. A progressive return to normalcy allowed for the organisation of presidential elections in late 2010. Once elected and behind a commitment to the reinforcement of the rule of law, the new president Michel Martelly refused to engage formally with non-state coercive actors, despite the fact that they continued to have a significant impact on public order in Port-au-Prince. Indeed, notwithstanding sustained efforts towards the reinforcement of the national police, informal public ordering continued to prevail in the regime and local armed groups were often associated to political patrons. Consequently, the security situation remained highly volatile during Martelly's presidency, and violence tended to increase during electoral periods.

\subsubsection{EI Salvador}

In El Salvador, the end of the armed conflict in 1992 paved the way to significant reforms targeting the State's security and justice sector, and allowed for the integration of the FMLN in the political life of the country. SSR significantly reduced the strength and the influence of the armed forces on domestic politics, allowed for the creation of a civilian police service, and slowly increased the independence of the justice system. Yet, changes in the structure of the post-war POR, spaces left vacant by the demobilisation of the guerrilla and state security forces, and lack of social and economic reforms created room for the emergence of new coercive actors in marginalised communities across the country. By the end of the 1990s, gangs were active in most major Salvadoran cities, 
exerting some control over marginalised communities to capture rent from extortion and drug distribution activities. While popular concerns toward public security increased through the 1990s and the media portrayed gangs as the main source of crime and violence, the Calderón Sol administration (1994-1999) did little to tackle the problem. Hence, despite the fact that post-war SSR had increased the capacity and to some extent the level of professionalism of state security institutions, the reforms did not manage to impose the State's monopoly over the POR. Nonetheless, the turn of the century saw a steady decline in homicide and victimization numbers.

Notwithstanding that drop in the levels of violence, president Francisco Flores announced in July 2003 the operation Mano Dura to reclaim control over communities oppressed by gangs. Yet, despite repressive police and military operations that led to the apprehension of thousands of alleged gang members, successive Mano Dura measures did not manage to reduce crime and gangs' prevalence in low-income communities. Indeed, weaknesses along the criminal justice chain, resulting in large part from incomplete SSR in the 1990s, undermined the State's strategy and created an environment conductive to informal state public ordering, leading to extrajudicial violence and human rights abuses. Furthermore, the government's strategy forced gangs to intensify extortion activities, which then contributed to turf wars between rival cliques. Mano Dura, in sum, backfired: homicide rates increased significantly between 2003 and 2005, reversing the last 10-year trend and making El Salvador one of the most violent countries worldwide.

The incapacity of the successive ARENA governments to deal with crime and violence contributed to the election of the first FMLN government in 2009. During the 
electoral campaign, the FMLN proposed a new public security strategy, based on violence prevention, reinsertion, and institutional reforms. Yet, within its first six months in power, the Funes administration backtracked and increased the role of the military forces in public security. Popular pressure for repressive actions against gangs provoked a return to reactive crime-control strategies and opened the door to extrajudicial violence by state actors. In response to state repression, gangs used intense violence to resist government pressure and reassert their claims in the country's POR.

In March 2012 however, homicides dropped abruptly, as a result of a state-brokered truce between the MS-13 and La18. Over the following months, the deal endured and created opportunities for the State to enter communities and provide services to the population in spaces where it was previously too dangerous to do so. In early 2013 , the creation of peace zones through dialogue between local stakeholders - gangs, politicians, police officers, local leaders, and so on - further contributed to the formalization of gangs' authority in the POR. If gangs became arguably more powerful, their ability to use violence was also constricted. Yet, once it became clear that none of the candidates to the 2014 presidential elections would support the truce due to its unpopularity with the electorate, the deal fell apart and violence rose again.

\subsubsection{The main findings and their implications for the proposed theory}

The effect of SSR on public order regimes in Haiti and El Salvador varies based on the strategy chosen to deal with non-state coercive actors and informal public ordering. In Haiti, the mixed strategy adopted under Préval, combined to more classic reforms targeting state institutions, stabilized the POR and had a positive impact on the level of order it produced. It formalized to some degree local public ordering and eliminated 
disruptive non-state actors. As a result, the streets of Port-au-Prince were safer, and it created space for local and international peace-building and development initiatives.

In El Salvador, the 2012-2013 gang truce succeeded where all previous approaches failed: reducing homicides. While SSR is usually conceived as a prerequisite for crime and violence control, in El Salvador, controlling violence became necessary to implement reforms, to develop new policing approaches and practices, and to formalize public ordering. By stopping violence, the truce stabilised the POR, and created space to renegotiate claims over the means of violence in spaces dominated by gang's public ordering. If some commentators considered that negotiating with criminals was unacceptable ${ }^{709}$ it nonetheless improved to some extend the daily life of some of the most vulnerable Salvadorans, reduced disruption due to constant conflict between coercive actors, and created a window of opportunity to increase the relative weight of formal public ordering in the Salvadoran POR.

In the two other cases however, the refusal of state officials to engage with non-state actors and address informal public order showed the limits of state-centric SSR. When powerful coercive actors had strong incentives to enforce public order and claim control over the means of violence in the POR, state-centric SSR undermined security and

\footnotetext{
${ }^{709}$ Alberto Arce, "El Salvador Throws Out Gang Truce and Officials Who Put It in Place," The New York Times, May 20, 2016, http://www.nytimes.com/2016/05/21/world/americas/el-salvador-throws-out-gangtruce-and-officials-who-put-it-in-place.html; Steven Dudley, “The El Salvador Gang Truce and the Church: What Was the Role of the Catholic Church?," CLALS Working Papers Series (Washington, D.C.: Center for Latin American \& Latino Studies, May 5, 2013); Steven Dudley and Elyssa Pachico, "El Salvador's Gang Truce: Positives and Negatives" (Insight Crime, June 2013); Jessel Santos, "Nuevo Ministro de Seguridad Desliga a Gobierno de Tregua," La Prensa Gráfica, May 30, 2013, http://www.laprensagrafica.com/nuevo-ministro-de-seguridad-desliga-a-gobierno-de-tregua; Jessel Santos, "Fiscal: La Tregua Es Una 'negociación Hipócrita,"” La Prensa Gráfica, April 18, 2013, http://www.laprensagrafica.com/fiscal--la-tregua-es-una--negociacion-hipocrita-; Marco Aleman, "Farsa la tregua en El Salvador," La Opinión, September 7, 2012, http://www.laopinion.com/2012/09/07/farsa-latregua-en-el-salvador/.
} 
stability. In Haiti under Martelly, the state-centric SSR strategy only targeted a fraction of the POR, while local armed groups continued to have strong incentives to impose themselves locally. The predominance of informality in popular neighbourhoods of Portau-Prince and the limited formal state presence sometimes created tensions when the police and MINUSTAH tried to provide formal public order. Other times, the lack of effective formal state presence enabled non-state actors to compete openly for the control of economic assets such as public markets. Focussing solely on state security institutions did not result in a higher level of public order, despite the strong international presence.

In El Salvador under Mano Dura, the State proved incapable of eliminating disruptive non-state coercive actors due in part to a dysfunctional criminal justice system that allowed for informal state public ordering exhibiting the limits of the post-war SSR process. Instead, repression backfired, forcing gangs to intensify their extortive activities and weakening the State's relative control on the means of violence in the POR. This case suggests that eliminating competing coercive actors and establishing the State's monopoly on public order might be more complicated than first envisioned.

All things considered, the four case studies demonstrate the relevance and the utility of the public order regime framework to make sense more systematically of the public security landscape in hybrid polities. The empirical analysis presented in chapter five to eight strongly supports the notion that security and public order are not the sole purview of the State in fragile settings. Indeed, state and non-state actors produce public order through both formal and informal means where they have an incentive to do so. Like nonstate actors, the State only engages in public ordering when it has an incentive to do so, resulting often in an incomplete public order regime. The POR framework constitutes an 
analytical tool that makes it possible to systematically map out relations of power and authority in a given context, ultimately facilitating comparison and contrast. It also helps to understand gap in security provision, as well as informal arrangements that often seem counterintuitive to outsiders and invisible to those who live under them because they are to a large extent taken for granted, "naturalised."

Furthermore, results from the empirical analysis support the intuition behind this project: SSR, as currently conceived, is unlikely to make people safer. On the one hand, the impact of state-centric SSR is likely to be limited and short-lived since it only addresses a limited portion of the POR. The disruptive potential of SSR increases when the reform process threatens the interests of coercive actors who have a strong incentive to maintain existing arrangements. In these cases, SSR is unlikely to improve public order and will likely backfire. While SSR is a disruptive process, taking into consideration the entire public ordering landscape in the implementation of these reforms can help mitigate its potential negative impact on public order and may actually increase the capacity of these reform to control armed crime and violence.

All in all, conceiving fragile states as public order regimes helps better understand the consequences of increasing state capacity in contexts where multiple actors claim control over the means of violence. It also provides important insights about how international donors and stakeholders can maximise the impact of assistance programs to the security sector of fragile states. The next section identifies some key policy implications deriving from this enquiry.

\subsection{Policy implications for SSR in fragile states}


Some important policy implications for security sector reform and broader statebuilding interventions can be drawn from this project. Reconsidering the rationale behind the state-building paradigm, I have come to question whether objectives and benchmarks fixed for SSR are in any way realistic. Indeed, reforms aiming at creating a monist POR or even just ensuring that the State control the largest share of violence is a difficult, costly, and likely long-term endeavour. Like other researchers, I call for a more pragmatic approach to these reforms, not based on the Weberian ideal-type, but rather anchored in a finer understanding of the complex composition of governance structures in hybrid polities. ${ }^{710}$ Rethinking what constitutes SSR success and tempering western expectations about this process is an essential first step.

First, as discussed early in this dissertation, SSR is usually conceived as a series of reforms that seek to transform how security and justice is provided to the population in accordance with good governance principles, including transparency, accountability, and respect for human rights. Both the $\mathrm{UN}$ and the OECD recognize to some extent the necessity to develop a people-centred approach, making sure that SSR enables state institutions to control violent crime and violence, making people safer. In fragile states, the provision of security and public order is never a State's monopoly. Yet, SSR tends to assume that it is necessarily done better by the formal activities of state institutions,

\footnotetext{
${ }^{710}$ Research presenting some variations of this argument includes Peter Albrecht, "Building on What Works: Local Actors and Service Delivery in Fragile Situations," in Handbook of International Security and Development, ed. Paul Jackson (Cheltenham, UK ; Northampton, MA, USA: Edward Elgar Pub, 2015), 279-93; Ursula C. Schroeder and Fairlie Chappuis, "New Perspectives on Security Sector Reform: The Role of Local Agency and Domestic Politics," International Peacekeeping 21, no. 2 (March 15, 2014): 133-48, doi:10.1080/13533312.2014.910401; Sabine Mannitz, "From Paternalism to Facilitation: SSR Shortcomings and the Potential of Social Anthropological Perspectives," International Peacekeeping 21, no. 2 (March 15, 2014): 269-85, doi:10.1080/13533312.2014.910403; Eric Scheye, "Realism and Pragmatism in Security Sector Development," United States Institute of Peace Special Report (Washington, D.C.: United States Institute of Peace (USIP), October 2010).
} 
ignoring the actual and potential role of non-state actors and the informal actions of state agents. When these programs do consider the informal and the non-state, they are usually conceived as something that must be eliminated, even though in fragile settings, informal public ordering and non-state actors often represent sources of security provision and public order that the State rarely has the capacity to replace.

The experience of USAID in Ilopango in 2013 and of the Haiti Stabilization Initiative in Cité Soleil, in 2007-2009, illustrates how it is not always possible to ignore or exclude non-state coercive actors. Yet, when external actors engage with non-state actors and informal governance, it is usually done in an ad hoc and often covert manner, without much reflection about the consequences of these interactions or a strategic and long-term view of the role of such engagement in consolidating a functional POR. If the objective of SSR is first and foremost to improve the security and the wellbeing of the population, a more open and less normative perspective not narrowly anchored in western norms of good governance might be necessary. Replacing the normative requirement of SSR by a more pragmatic approach that considers potential disruption and the actual capacity of different actors to claim control over the means of violence and to provide security to the population might be a more promising avenue toward stability and security, and a less costly one as well. It might also help those organisations and agencies on the ground who struggle to implement effective solutions as a result of the poor fit of western guidelines in complex, non-western environments.

Nonetheless, SSR strategies based on a thorough assessment of the structure of the public order regime do not necessarily mean a complete rejection of the goal of establishing the State's monopoly over the POR. In fact, it opens the way to the 
elaboration of incremental SSR strategies where the impact of increased state capacity on the regime is taken into consideration, mitigating disruption and conflict. At the same time, directly addressing the role and place of non-state actors in the SSR process can help formalise their authority and constrain their use of violence. Eliminating particularly disruptive coercive actors might be necessary, but getting rid of non-state public ordering does not need to be the default strategy. As illustrated in the cases of the "disarm or die" strategy in Haiti or the gang truce in El Salvador, it is possible to constrict and formalize non-state coercive actors in ways that contribute to higher levels of public order and further reforms.

Finally, SSR is not a linear process. It remains vulnerable to external shocks, such as the January 2010 earthquake in Haiti or abrupt political changes following elections. Consequently, SSR is more likely to produce desirable outcomes if it remains anchored in a regular assessment of the environment of intervention guided by the POR framework. Incremental objectives based on a pragmatic assessment of capacities, interests, and competing claims within the POR are more likely to bear positive results. Furthermore, making sure that programming is aligned with local needs and incentives is more important than ensuring that reforms check all the criteria provided by international frameworks and guidelines. Otherwise, SSR is likely to produce little result or may well contribute to instability and insecurity.

This last point highlights how any SSR program is dependent on the political appetite of local elites. The refusal of state officials to engage formally with non-state coercive actors, as in Haiti under Martelly and in El Salvador under Mano Dura measures, can prevent SSR endeavours from addressing directly the entire POR. In these cases, external 
actors can try to alter the incentive structure faced by rulers, while engaging with the rest of the POR through local development and peace-building programs. Nonetheless, if the State is not on board with a broad reform process, prospects for SSR will remain low.

All in all, future SSR endeavours are more likely to reach their objectives if they take into consideration the entire public ordering landscape of fragile states and their potential impact on the balance of power between coercive actors. Incremental strategies might also be more promising than tabula rasa approaches that have shown very little success since the beginning of the $21^{\text {st }}$ century.

\subsection{The next steps}

This project is a plausibility probe that intended to verify whether the proposed hypotheses warrant more systematic testing. Based on the results obtained, I consider that the POR framework and its implications for SSR in fragile states are promising enough to justify further enquiry. A structured comparison based on additional case studies constitutes a logical next step to test and further refine the proposed hypotheses.

Another interesting line of enquiry is the motivations of coercive actors. For both state and non-state actors, public ordering is a costly activity that is justified by benefits deriving from rent-seeking activities. In the case of non-state actors, rent-seeking activities discussed in the case studies include extortion, protection rackets, and drug distribution. For state actors, the cases suggest that incentives to produce public order are closely linked to political gains and survival. In both cases, exploring in more depth the sources of motivations for state and non-state actors would contribute to understand violence and instability in fragile states that are not at war. 
Finally and perhaps most significantly, the POR framework offers analytical power and relevance beyond SSR. It helps better understand relations of power in contexts where the State cohabits with other coercive actors, at the national and subnational levels. It constitutes a framework of analysis that systematically integrates concepts such as twilight institutions, governance beyond statehood, and legal pluralism. Hence, the analytical power and policy relevance of the public order regime concept paves the way to a new body of research to better understand authority, coercion, and violence, where narrowly Weberian perspectives fail to account for complex realities. Rather than asking what should ultimately be, the POR framework helps us better understand what is, what should be the first step of any intervention endeavour in fragile states.

$* * *$ 
Appendices 


\section{Appendix A Abbreviations and Acronyms}

ANSP Academia Nacional de Seguridad Pública

(National Academy of Public Security)

ARENA Alianza Nacionalista Republicana

CEPES Centro de Estudios Penales de El Salvador

(Centre for Criminal Studies)

CNDDR Commission nationale pour le désarmement, la démantèlement et la reinsertion

(National commission for disarmament, demobilisation, and reinsertion)

CNG Conseil National de Gouvernement

(Government National Council)

CSPN Conseil Supérieur de la Police Nationale

(High Council of the National Police)

CVR Community Violence Reduction Unit

DCPJ Direction centrale de la police judiciaire

(Central Directorate of the Judicial Police)

DDR Disarmament, demobilisation, and reintegration

DFID United Kingdom's Department for International Development

DPKO United Nations’ Department of Peace Keeping Operations

FAd'H Forces Armées d'Haïti

(Haiti Armed Forces)

FESPAD Fundación de Estudios para la Aplicación del Derecho

(Research Foundation for the Application of the Law)

FGR Fiscal General de la República

(Attorney General's Office)

FMLN Frente Farabundo Martí para la Liberacíon Nacional

FPU Formed police unit

FUSADES Fundación Salvadoreña para El Desarrollo Economico y Social (Salvadoran Foundation for Economic and Social Development) 


$\begin{array}{ll}\text { GDP } & \text { Gross Domestic Product } \\ \text { HSI } & \text { Haiti Stabilization Initiative } \\ \text { IDB } & \text { Inter-American Development Bank } \\ \text { IGPNC } & \begin{array}{l}\text { Inspectoría General de la Policía Nacional Civil } \\ \text { (The PNC General Inspectorate) }\end{array} \\ \text { IML } & \begin{array}{l}\text { Instituto de Medicina Legal } \\ \text { (Institute of Forensic Medecine) }\end{array} \\ \text { IUDOP } & \begin{array}{l}\text { Instituto Universitario de Opinión Publica } \\ \text { (University Institute of Public Opinion) }\end{array} \\ \text { JMAC } & \text { Joint Mission Analysis Centre } \\ \text { LAM I } & \begin{array}{l}\text { Ley Anti Maras } \\ \text { (Anti-Maras Act) }\end{array} \\ \text { LAM II } & \begin{array}{l}\text { Ley Para el Combate de las Actividades Delincuenciales de Grupos o } \\ \text { Asociaciones Ilícitas Especiales } \\ \text { (Law to Combat Delinquent Activities of Special Illicit Groups or }\end{array} \\ & \text { Associations) } \\ \text { Barrio 18/18 }\end{array}$


OECD-DAC Development Assistance Committee of the Organisation for Economic Co-operation and Development

OIE Organismo de Inteligencia del Estado

(State Intelligence Agency)

ONUSAL United Nations Observers Mission to El Salvador

PATI Programa de Apoyo Temporal al Ingreso

(Temporary Access Support Program)

PDDH Procuraduría para la Defensa de los Derechos Humanos

(Ombudsman Office for the Defence of Human Rights)

PNC Policía Nacional Civil

(National Civilian Police)

PNH Police Nationale Haïtienne

(Haitian National Police)

PNJSPC Política Nacional de Justicia, Seguridad Publica y Convivencia (National

Policy for Justice, Public Security, and Coexistence)

POR Public order regime

RDC-ML Rassemblement congolais pour la démocratie - Mouvement de liberation

RNDDH Réseau National de défense des droits de l'homme

(National Human Rights Defense Network)

SRSG Special Representative of the Secretary General

SSR Security sector reform

UEA Unidad Ejecutiva Antinarcotráfico

(anti-narcotic unit)

UN United Nations

UNDP United Nations Development Programme

UNMIH United Nations Mission in Haiti

UNPol United Nations International Police Officer

UNODC United Nations Office on Drugs and Crime 
UNSC United Nations Security Council

USAID United States Agency for International Development

WHO World Health Organization 


\section{References}

Abbott, Elizabeth. Haiti: A Shattered Nation. New York ; London: Overlook Duckworth, 2011.

Albrecht, Peter. "Building on What Works: Local Actors and Service Delivery in Fragile Situations." In Handbook of International Security and Development, edited by Paul Jackson, 279-93. Cheltenham, UK ; Northampton, MA, USA: Edward Elgar Pub, 2015.

Albrecht, Peter, and Helene Maria Kyed. "Local Actors in Security and Justice Programming." In Handbook of International Security and Development, edited by Paul Jackson, 248-62. Cheltenham, UK ; Northampton, MA, USA: Edward Elgar Pub, 2015.

Aleman, Marco. "Farsa la tregua en El Salvador.” La Opinión, September 7, 2012. http://www.laopinion.com/2012/09/07/farsa-la-tregua-en-el-salvador/.

Allison, Mike. “A Changing of the Guard in El Salvador.” Al Jazeera, November 29, 2001.

http://www.aljazeera.com/indepth/opinion/2011/11/20111128111359866466.html

Alphonse, Roberson. "Croix-Des-Bossales et Martissant, Comme Des Volcans En Activité." Le Nouvelliste. February 18, 2016.

http://lenouvelliste.com/lenouvelliste/article/155702/Croix-des-Bossales-etMartissant-comme-des-volcans-en-activite.

Alston, Lee J. "The Development of Property Rights on Frontiers: Endowments, Norms, and Politics." The Journal of Economic History 72, no. 3 (September 1, 2012): 741-70.

Amaya Cobar, E. A., and O. E. Feusier Alaya. "Relación Entre La Fiscalía General de La República Y La Policía Nacional Civil En El Marco de La Investigación Criminal." San Salvador, El Salvador: FESPAD, 2005.

Amaya Cóbar, Edgardo A. "Quince Años De Reforma Policial En El Salvador : Avances Y Desafíos." Urvio, Revista Latinoamericana de Seguridad Publica, no. 2 (2007): 127-44.

Amaya, Edgardo Alberto. "Security Policies in El Salvador, 1992-2002." In Public Security and Police Reform in the Americas, edited by John Bailey and Lucía Dammert. Pittsburg: University of Pittsburgh Press, 2006.

Amnesty International. “Amnesty International Report 2005 - El Salvador,” May 25, 2005. http://www.refworld.org/docid/429b27f67.html.

- - _. "El Salvador: Open Letter on the Anti-Maras Act." Amnesty International, December 2003.

- - . "El Salvador: The Spectre of Death Squads." Amnesty International, December 1996. 
- - - "Facts and Figures - Haiti: Displaced People Still Leave in Despair Four Years after Devastating Earthquake," January 9, 2014.

http://reliefweb.int/sites/reliefweb.int/files/resources/Displaced\%20people\%20stil $1 \% 20$ leave $\% 20 \mathrm{in} \% 20$ despair\%20four\%20years\%20after\%20devastating\%20arth quake.pdf.

- - - "Haiti: Breaking the Cycle of Violence: A Last Chance for Haiti?" Amnesty International, June 21, 2004. http://www.refworld .org/docid/42ae98630.html.

- - - . "Haiti: Human Rights Challenges Facing the New Government." Amnesty International, April 19, 2001. http://www.refworld.org/docid/3c29def0e.html.

- - - "Report 2001: Haiti." Report 2001, June 1, 2001. http://www.refworld.org/docid/3b1de37710.html.

Andersen, Louise Riis. "Security Sector Reform and the Dilemmas of Liberal Peacebuilding." DIIS Working Paper. Copenhagen. Denmark: Danish Institute for International Studies, 2011.

- - - "When Security Is Found Beyond the State: Suggestions for a Revised Approach to Security Reform in Fragile States." Forum for Development Studies 33, no. 2 (2006): 305-24.

Anderson, John Lee. "Aftershocks: Haiti Since the Earthquake." The New Yorker, February 1, 2016. http://www.newyorker.com/magazine/2016/02/01/aftershocksletter-from-haiti-jon-lee-anderson.

Andreas, Peter. "Symbiosis Between Peace Operations and Illicit Business in Bosnia." International Peacekeeping 16, no. 1 (January 26, 2009): 33-46. doi:10.1080/13533310802485518.

AP-Reuter. "Informe Sobre Escuadrones de La Muerte En El Salvador." Eltiempo.com, July 29, 1994. http://www.eltiempo.com/archivo/documento/MAM-183566.

Arana, Ana. "How the Street Gangs Took Central America." Foreign Affairs 84, no. 3 (June 5, 2005): 98-110.

Arce, Alberto. "El Salvador Throws Out Gang Truce and Officials Who Put It in Place." The New York Times, May 20, 2016. http://www.nytimes.com/2016/05/21/world/americas/el-salvador-throws-outgang-truce-and-officials-who-put-it-in-place.html.

Archibold, Randal C. "In El Salvador, Violence Falls Amid a Gang Truce." The New York Times, August 27, 2012.

http://www.nytimes.com/2012/08/28/world/americas/in-el-salvador-gang-trucebrings-tenuous-peace.html.

Argueta, Sandra, Gisela Caminos, Margarita Mancia, and Maria de los Angeles Salgado. "Diagnostico Sobre Los Grupos Llamados 'Maras' En San Salvador: Factores Psicosociales Que Prevalecen En Los Jovenes Que Los Integran".” Bachelor's thesis, Universidad Centroamericana “José Simeon Canas" de El Salvador, 1991. 
Arias, Enrique Desmond. Drugs and Democracy in Rio de Janeiro: Trafficking, Social Networks, and Public Security. Chapel Hill: University of North Carolina Press, 2006.

Ariosto, David. "Violence Grips Haiti after Contested Elections." Al Jazeera America, November 12, 2015. http://america.aljazeera.com/articles/2015/11/12/violencegrips-haiti-after-contested-elections.html.

Arjona, Ana. "Wartime Institutions A Research Agenda." Journal of Conflict Resolution, September 23, 2014, 22002714547904. doi:10.1177/0022002714547904.

Autesserre, Séverine. Peaceland: Conflict Resolution and the Everyday Politics of International Intervention. Cambridge University Press, 2014.

- - - "Trouble in Peaceland." Foreign Policy, October 6, 2015. https://foreignpolicy.com/2015/10/06/trouble-in-peaceland-united-nations-congodevelopment/.

Ávalos, Jessica, and Ricardo Flores. "Gobierno Facilita a Iglesia Negociación Por Extorsiones.” La Prensa Gráfica. April 12, 2012. http://www.laprensagrafica.com/el-salvador/judicial/257650-gobierno-facilita-aiglesia-negociacion-por-extorsiones.html.

Axworthy, Lloyd. "Human Security and Global Governance: Putting People First." Global Governance 7, no. 1 (2001): 19-23.

Baker, Bruce. "Justice and Security Architecture in Africa: The Plans, the Bricks, the Purse and the Builder." Journal of Legal Pluralism and Unofficial Law 63 (2011): 25-48.

- - . Multi-Choice Policing in Africa. Uppsala: Nordiska Afrikainstitutet, 2008.

- - - . "The Future Is Non-State." In The Future of Security Sector Reform, edited by Mark Sedra, Centre for International Governance Innovation., 208-28. Waterloo (On), 2010.

Baptiste, Juno Jean. "Marché de La Croix-Des-Bossales, Spirale de Terreur." Le Nouvelliste, August 22, 2014. http://lenouvelliste.com/lenouvelliste/article/134641/Marche-de-la-Croix-desBossales-spirale-de-terreur.html.

Baranyi, Stephen, and Yves Sainsiné. "Le Développement de La PNH, La Sécurité Publique et l'État de Droit En Haïti." Université d'État d'Haïti, Université d'Ottawa, Agence universitaire de la Francophonie, May 15, 2015. https://sciencessociales.uottawa.ca/developpement-internationalmondialisation/nouvelles/professeur-agrege-stephen-baranyi-professeur-yvessinsine-luniversite-detat-dhaiti-ont.

Bargent, James. "El Salvador Truce Mediators Call for Repeal of Anti-Gang Law." Insight Crime, November 28, 2012. http://www.insightcrime.org/news-briefs/elsalvador-gang-truce-mediators-repeal-anti-gang-law. 
- - - "Ex-Minister Accused of Interfering in El Salvador Anti-Gang Ops." Insight Crime, June 28, 2013. http://www.insightcrime.org/news-briefs/ex-ministeraccused-of-interfering-in-anti-gang-ops-in-el-salvador.

Bates, Robert H. When Things Fell Apart: State Failure in Late-Century Africa. Cambridge Studies in Comparative Politics. New York: Cambridge University Press, 2008.

BBC Monitoring. "Haiti: Aristide Visits Police, Supports Summary Action And 'zero Tolerance,"” June 21, 2001. http://faculty.webster.edu/corbetre/haitiarchive/msg08197.html.

Becker, David C. "Gangs, Netwar, and the 'Community Counterinsurgency' in Haiti." Prism 2, no. 3 (2011): 137-54.

Becker, David C., and Robert Grossman-Vermaas. "Metrics for the Haiti Stabilization Initiative." PRISM 2, no. 2 (2011): 145-58.

Beidas, Sandra, Colin Granderson, and Rachel Neild. "Justice and Security Reform after Intervention: Haiti." In Constructing Justice And Security After War, edited by Charles Call, 69-112. Washington, DC: US Institute of Peace Press, 2007.

Bender, Bryan. "Haiti Violence Is Seen as Worsening." Boston Globe. October 23, 2004.

Bendix, Daniel, and Ruth Stanley. "Deconstructing Local Ownership of Security Sector Reform: A Review of the Literature." African Security Review 17, no. 2 (2008): 93-104.

Bercovith, Daniella. "Less Guns, More Peace in Haiti." Comunidade Segura, August 31, 2007. http://www.comunidadesegura.org.br/fr/node/36554?q=en/node/36020.

Berdal, Mats, and Dominik Zaum, eds. Political Economy of Statebuilding; Power after Peace. Routledge. Routledge Studies in Intervention and Statebuilding. London; New York, 2013.

Berg, Louis-Alexandre. "Guns, Laws and Politics: The Political Foundations of Rule of Law and Security Sector Reform." Hague Journal on the Rule of Law 4, no. Special Issue 01 (2012): 4-30. doi:10.1017/S1876404512000024.

- - - "Young but Not Alone; Youth Organizations and the Local Politics of Security Provision." In Policing and the Politics of Order-Making, edited by Peter Albrecht and Helene Maria Kyed, 159-77. London ; New York: Routledge, 2015.

Berk-Seligson, Susan, Diana Orcés, Georgina Pizzolitto, Mitchell A. Seligson, and Carole J. Wilson. "Impact Evaluation of USAID's Community-Based Crime and Violence Prevention Approach in Central America: Regional Report for El Salvador, Guatemala, Honduras and Panama." Nashville TN: Latin American Public Opinion Project/Vanderbilt University, October 2014.

Berthiaume, Lee. "Canadian Promise to Build Haitian Police Academy in Limbo." Ottawa Citizen. 2014 2014. http://ottawacitizen.com/news/politics/canadianpromise-to-build-haitian-police-academy-in-limbo. 
Bøås, Morten, and Liv Elin Torheim. "The Trouble in Mali-corruption, Collusion, Resistance.” Third World Quarterly 34, no. 7 (2013): 1279-92.

Boege, Volker, Anne Brown, Kevin Clements, and Anna Nolan. "On Hybrid Political Orders and Emerging States: State Formation in the Context of 'fragility.", Berghof Research Center for Constructive Conflict Management, 2008.

Boege, Volker, M. Anne Brown, and Kevin P. Clements. "Hybrid Political Orders, Not Fragile States." Peace Review 21, no. 1 (March 1, 2009): 13-21. doi:10.1080/10402650802689997.

Bohannon, John. "Counting the Dead in Afghanistan.” Science 331, no. 6022 (March 11, 2011): 1256-60. doi:10.1126/science.331.6022.1256.

Boraz, Steven C., and Thomas Bruneau. "Are the Maras Overwhelming Governments in Central America?” Military Review, no. November-December (2006): 36-40.

Boutros-Ghali, Boutros. "An Agenda for Peace." Report of the Secretary-General. New York: United Nations, June 17, 1992.

Brigety, Reuben, and Natalie Ondiak. "Haiti’s Changing Tide.” Washington, D.C.: Center for American Progrss, September 1, 2009. https://www.americanprogress.org/issues/security/report/2009/09/01/6650/haitischanging-tide/.

Bruneau, Thomas C. "Pandillas and Security in Central America." Latin American Research Review 49, no. 2 (2014): 152-72. doi:10.1353/lar.2014.0022.

Bruneau, Thomas, Lucía Dammert, and Elizabeth Skinner. Maras: Gang Violence and Security in Central America. Austin: University of Texas Press, 2011.

Brzoska, Michael. "Introduction: Criteria for Evaluating Post-Conflict Reconstruction and Security Sector Reform in Peace Support Operations." International Peacekeeping 13, no. 1 (2006): 1-13.

Bureau of Democracy, Human Rights, and Labour. "El Salvador: 2008 Country Report on Human Rights Practices." Washington, D.C.: U.S. Department of State, February 25, 2009. http://www.state.gov/j/drl/rls/hrrpt/2008/wha/119159.htm.

Buvinic, Mayra, and Andrew Morrison. “How Is Violence Measured?” Inter-American Development Bank, July 1, 1999. http://publications.iadb.org/handle/11319/5271.

Call, Charles T. “Assessing El Salvador's Transition from Civil War to Peace.” In Ending Civil Wars: The Implementation of Peace Agreements, edited by Stephen J.

Stedman, Donald S. Rothchild, and Elizabeth Cousens, 383-420. Boulder: Lynne Rienner Publishers, 2002.

- - - "Democratisation, War and State-Building: Constructing the Rule of Law in El Salvador.” Journal of Latin American Studies 35, no. 4 (2003): 827-62.

- _ _. "The Mugging of a Success Story: Justice and Security Reform in El Salvador." In Constructing Justice and Security after War, edited by Charles T. Call, 29-67. Washington, DC: US Institute of Peace Press, 2007. 
Call, Charles T., and Elizabeth Cousens. Ending Wars and Building Peace: Coping with Crisis. New York: International Peace Academy, 2007.

Call, Charles T., and Vanessa Wyeth. Building States to Build Peace. Boulder: Lynne Rienner Publishers, 2008.

Central Intelligence Agency. "Central America and Caribbean: Haiti." The World Factbook, November 3, 2016. https://www.cia.gov/library/publications/the-worldfactbook/geos/ha.html.

Chanaa, Jane. Security Sector Reform: Issues, Challenges and Prospects. London ; New York: Routledge, 2002.

Chávez, Suchit. "FGR Acusa a Exministro de Seguridad de Entorpecer Captura de Pandilleros." La Prensa Gráfica, June 27, 2013.

http://www.laprensagrafica.com/fgr-acusa-a-exministro-de-seguridad-deentorpecer-captura-de-pandilleros.

Chavez, Suchit. "Moreno:tregua Fue Politica de Estado de Funes." La Prensa Gráfica. June 17, 2016.

CIDA, DFAIT/START, and NCA. "Évaluation Conjointe De 'l'intervention de Viva Rio Dans La Zone de Bel Air' en Haït - Appuyée Par l’ACDI, Le MAECI/GTSR et NCA," May 3, 2011. http://www.vivario.org.br/wpcontent/themes/vivario/bibliotecaepesquisa/relatoriosdeavaliacao/evaluation_de_1 action_de_vivario/evaluation_intervention_de_vivario_a_bel_air_2011_fr.pdf.

Civic, Melanne A., and Michael Miklaucic, eds. Monopoly of Force : The Nexus of DDR and SSR. Washington, DC: National Defense University Press, 2011.

Clements, Kevin P., Volker Boege, Anne Brown, Wendy Foley, and Anna Nolan. "State Building Reconsidered: The Role of Hybridity in the Formation of Political Order." Political Science 59, no. 1 (June 1, 2007): 45-56.

CNN Español. "Mauricio Funes: 'Tregua de Las Maras Entró En Crisis, Pero No Se Ha Roto." CNNEspañol.com, December 9, 2013. http://cnnespanol.cnn.com/2013/12/09/mauricio-funes-tregua-de-las-maras-entroen-crisis-pero-no-se-ha-roto/.

Cockayne, James. "Winning Haiti's Protection Competition: Organized Crime and Peace Operations Past, Present and Future." International Peacekeeping 16, no. 1 (2009): 77-99. doi:http://dx.doi.org.proxy.library.carleton.ca/10.1080/13533310802485476.

Collier, Paul. "Haiti: From Natural Catastrophe to Economic Security. A Report for the Secretary-General of the United Nations," January 2009.

Commission Episcopale Nationale Justice et Paix. "Violence Dans La Zone Métropolitaine de Port-Au-Prince." Port-au-Prince: Commission Episcopale Nationale Justice et Paix, March 10, 2015.

Conseil Supérieur de la Police Nationale. "Bilan de La Mise En Oeuvre Du Plan De Développement de La Police Nationale d'Haïti 2012-2016 (Sur La Période de Septembr 2012 À Juin 2013).” Port-au-Prince, August 19, 2013. 
http://www.slideshare.net/laurentlamothe/plan-de-dveloppement-de-la-policenationale-dhati-20122016.

Corporación Latinobarómetro. “Latinobarómetro 2011.” Corporación Latinobarómetro, 2011.

Costa, Gino. "Demilitarizing Public Security: Lessons from El Salvador.” In EL Salvador: Implementation of the Peace Accords, edited by Margarita S. Studemeister, 20-26. Washington, D.C.: United States Institute of Peace, 2001.

- - - "The United Nations and Reform of the Police in El Salvador." International Peacekeeping 2, no. 3 (1995): 365-90. doi:10.1080/13533319508413567.

Craig, Paul. "Formal and Substantive Conceptions of the Rule of Law: An Analytical Framework.” Public Law, 1997, 467-487.

Cruz, José Miguel. "Criminal Violence and Democratization in Central America: The Survival of the Violent State." Latin American Politics and Society 53, no. 4 (2011): 1-33.

- - - "Global Gangs in El Salvador: Maras and the Politics of Violence." presented at the Global Gangs Workshop, Centre on Conflict, Development and Peacebuilding, Geneva, May 14, 2009.

- - _. "Government Responses and the Dark Side of Gang Suppression in Central America." In Maras: Gang Violence and Security in Central America, edited by Thomas Bruneau, Lucía Dammert, and Elizabeth Skinner, 137-57. Austin: University of Texas Press, 2011.

- - - "Pandillas Y Capital Social." In Estudios Centroamericanos, 1099-1118. San Salvador, El Salvador: Universidad Centroamericana, 2001.

- - - Street Gangs in El Salvador. UCA Editores. San Salvador, El Salvador, 2007.

- - _. "The Peace Accords Ten Years Later: A Citizen's Perspective.” In El Salvador's Democratic Transition Ten Years After the Peace Accord, edited by Cynthia Arnson. Washington, D.C.: Woodrow Wilson International Center for Scholar, 2003.

- - - "Violence, Citizen Insecurity, and Elite Maneuvering in El Salvador." In Public Security and Police Reform in the Americas, edited by John Bailey and Lucía Dammert. Pittsburg: University of Pittsburgh Press, 2006.

Cruz, José Miguel, and Angélica Durán-Martínez. "Hiding Violence to Deal with the State Criminal Pacts in El Salvador and Medellin." Journal of Peace Research, February 22, 2016, 22343315626239. doi:10.1177/0022343315626239.

Cruz, José Miguel, and Nelson Portillo. Solidaridad Y Violencia En Pas Pandillas Del Gran San Salvador: Mas Alla de La Vida Loca. San Salvador, El Salvador: UCA Editores, 1998.

Cruz, José Miguel, and Maria L. Santacruz Giralt. "La Victimización Y La Percepción de Seguridad En El Salvador En 2004.” Ministerio de Gobernacion, Républica de El Salvador; Program de las Naciones Unidas para el Desarollo, April 2005. 
Dammert, Lucia. "Seguridad Privada: Repuesta a Las Necesidades de Seguridad Publica En Conglomerados Urbanos?" Organizacion de los Estados Americanos, March 2008.

Danner, Mark. The Massacre at El Mozote. 1 edition. New York: Vintage, 1994.

Darius, Danio. “Anne Fuller Déplore Le Manque de Progrès En Haiti.” Le Nouvelliste. December 9, 2014. http://lenouvelliste.com/lenouvelliste/article/139076/AnneFuller-deplore-le-manque-de-progres-en-Haiti.

_ _ _ . "Les Bandits Sèment La Terreur À Martissant.” Le Nouvelliste. June 25, 2014. http://lenouvelliste.com/lenouvelliste/article/132718/Les-bandits-sement-laterreur-a-Martissant.

Daudelin, Jean. "Frontier Violence: Property Rights, Commons Management Costs and Distributional Conflicts.” Working paper, November 11, 2010.

Daugherty, Arron. "MS13 Launches Police Assassination Campaign in El Salvador." Insight Crime, April 9, 2015. http://www.insightcrime.org/news-briefs/ms13launches-police-assassination-campaign-el-salvador.

- - - . "Uniformed Men Massacre Alleged Gang Members in El Salvador." Insight Crime, May 11, 2015. http://www.insightcrime.org/news-briefs/uniformed-menmassacre-alleged-gang-members-el-salvador.

Davis, Diane E. "Non-State Armed Actors, New Imagined Communities, and Shifting Patterns of Sovereignty and Insecurity in the Modern World." Contemporary Security Policy 30, no. 2 (2009): 221-45.

Delva, Joseph Guyler, and Tom Brown. "Gangs Return to Haiti Slum after Quake Prison Break.” Reuters. January 17, 2010. http://www.reuters.com/article/2010/01/17/usquake-haiti-gangs-sb-idUSTRE60G0CO20100117.

Donais, Timothy. "Back to Square One: The Politics of Police Reform in Haiti." Civil Wars 7, no. 3 (2005): 270-87.

- - - "Haiti and the Dilemmas of Local Ownership." International Journal 64, no. 3 (2009): 753-73.

- - _ . "National Ownership and Post-Conflict Peace Building: From Principle to Practice." Policy Brief. Waterloo (On): Centre for International Governance Innovation, June 2014.

Donais, Timothy, and Amy C. Knorr. "Peacebuilding from below vs. the Liberal Peace: The Case of Haiti." Canadian Journal of Development Studies/Revue Canadienne d\&\#039;études Du Développement 34, no. 1 (2013): 54-69. doi:10.1080/02255189.2013.761130.

Dorn, A. Walter. "Intelligence-Led Peacekeeping: The United Nations Stabilization Mission in Haiti (MINUSTAH), 2006-07." Intelligence and National Security 24, no. 6 (2009): 805-35.

Dubois, Laurent. Haiti: The Aftershocks of History. 1st ed. New York: Henry Holt and Co, 2012. 
Dudley, Steven. "Mass Graves Burying the Truth about El Salvador Gang Truce." Insight Crime, January 1, 2014. http://www.insightcrime.org/news-analysis/homicidesmass-graves-and-truth-about-el-salvador-gang-truce.

- _ - "The El Salvador Gang Truce and the Church: What Was the Role of the Catholic Church?” CLALS Working Papers Series. Washington, D.C.: Center for Latin American \& Latino Studies, May 5, 2013.

Dudley, Steven, and Elyssa Pachico. "El Salvador's Gang Truce: Positives and Negatives.” Insight Crime, June 2013.

Dudouet, Véronique, Hans J. Giessmann, and Katrin Planta. "From Combatants to Peacebuilders: A Case for Inclusive, Participatory and Holistic Security Transitions." Policy Report. Berghof Foundation, 2012.

Dziedzic, Michael, and Robert M. Perito. "Haiti: Confronting the Gangs of Port-AuPrince." Special Report. Washington, D.C.: United States Institute of Peace (USIP), September 2008.

El Faro. "Editorial: PATI Para Pandilleros.” Elfaro.net. August 26, 2013. http://www .elfaro.net/es/201308/opinion/13096/.

El Salvador. General Amnesty Law for the Consolidation of Peace, Pub. L. No. Legislative Decree 486 (1993).

elsalvador.com. “QQuiénes Son Los Nuevos Funcionarios de Gobierno?” Http://Www.elsalvador.com/, January 22, 2016. http://www.elsalvador.com/articulo/nacional/quienes-son-los-nuevosfuncionarios-gobierno-99428.

Engler, Yves, and Anthony Fenton. Canada in Haiti: Waging War on the Poor Majority. Halifax: Fernwood Publishing, 2005.

Farah, Douglas. "Organized Crime in El Salvador: The Homegrown and Transnational Dimensions.” Working Paper Series on Organized Crime in Central America. Latin American Program, Woodrow Wilson International Center for Scholars, February 2011.

- - _ "The Transformation of El Salvador's Gangs into Political Actors." Center for Strategic and International Studies, June 21, 2012.

Fariña, Laura Pedraza, Spring Miller, and James Cavallaro. No Place to Hide: Gang, State, and Clandestine Violence in El Salvador. Human Rights Program Practice Series. Cambridge, Mass: Harvard University Press, 2010.

Fatton Jr., Robert. “Citizenship and Democratization in Haiti.” In The Future of Liberal Democracy, edited by Robert Fatton Jr. and R. K. Ramazani, 203-24. New York: Palgrave Macmillan, 2004.

Fatton, Robert. Haiti's Predatory Republic: The Unending Transition to Democracy. Boulder, Co: Lynne Rienner Publishers, 2002.

- - - . The Roots of Haitian Despotism. Boulder: Lynne Rienner Publishers, 2007. 
Felbab-Brown, Vanda. "Blood and Faith in Afghanistan: A June 2016 Update." Brookings, May 26, 2016. https://www.brookings.edu/research/blood-and-faithin-afghanistan-a-june-2016-update/.

- - - "Blood and Hope in Afghanistan: A June 2015 Update." The Brookings Institution, May 26, 2015. http://www.brookings.edu/research/papers/2015/05/26isis-taliban-afghanistan-felbabbrown.

FESPAD. "Informe Annual Sobre Justicia Penal El Salvador 2005." San Salvador, El Salvador: FESPAD, 2006.

FESPAD, and CEPES. "Informe Anual Sobre Justicia Penal Juvenil El Salvador 2004." FESPAD, 2005. http://www.wola.org/sites/default/files/downloadable/Citizen\%20Security/past/IP J2004.pdf.

FESPAD, CEPES, and Red Centroamericana de Jueces, Fiscales y Defensores por la Democratizacionde la Justicia. "Informe Para La Audiencia Sobre La Independencia Judicial En Centroamerica." report prepared for the InterAmerican Commission on Human Rights, 2004.

Fitzgerald, Paul, Rick Gold, Yve-François Pierre, and Bertrand Woldson. "Haiti Rule of Law Assessment. Final Report.” USAID, April 2015.

Fitzpatrick, D. "Evolution and Chaos in Property Right Systems: The Third World Tragedy of Contested Access." Yale LJ 115 (2005): 996.

Flores, Francisco. "Mensaje Emitido En Cadena de Radio Y Telivision Po El Presidente de La Republica, Francisco Flores, Durante El Anuncio de La Operacion 'Mano Dura' contra Las Pandillas.” San Salvador, El Salvador, July 23, 2003.

Flores, Gloria. "Munguía Payés Califica de 'humillante' Resolución de CSJ.” La Prensa Gráfica, May 21, 2013. http://www.laprensagrafica.com/munguia-payes-calificade--humillante--resolucion-de-csj.

Fluri, Philipp H., and V.G. Radetskiy. Security Sector Reform in Ukraine: Quo Vadis? DCAF. Geneva, 2010.

Foreign Affairs and International Trade Canada. "Summative Evaluation of START's Global Peace and Security Fund - Haiti." Ottawa: Foreign Affairs and International Trade Canada, April 2009.

Fortin, Isabelle. "Security Sector Reform in Haiti One Year after the Earthquake." SSR Issue Papers. Waterloo (On): Centre for International Governance Innovation, March 2011.

Fortin, Isabelle, and François-Pierre Pierre. "Haiti et La Réforme de La Police Nationale d'Haïti." Ottawa: The North-South Institute, December 2008.

Freedom House. “Country Report 2010: El Salvador.” Freedom House, 2010. https://freedomhouse.org/report/freedom-world/2010/el-salvador.

- - - . "Country Report: El Salvador 2008." Freedom House, 2008. https://freedomhouse.org/report/freedom-world/2008/el-salvador. 
- - - "Haiti. Freedom in the Wolrd 2013," 2013. https://freedomhouse.org/report/freedom-world/2013/haiti\#.VOC5bFPF9yR.

Frost, Michel. "Haiti/Droits Humains: Lettre Ouverte de Michel Forst Aux Haïtiens !" Canal Plus Haiti, March 27, 2013. http://www.canalplushaiti.net/haitidroitshumains-lettre-ouverte-de-michel-forst-aux-haitiens/.

Fukuyama, Francis. State-Building: Governance and World Order in the 21St Century. 1st ed. Ithaca: Cornell University Press, 2004.

Gagne, David. "El Salvador Gangs Take Credit for Homicide Drop During Romero's Beatification," May 28, 2015. http://www.insightcrime.org/news-briefs/elsalvador-gangs-take-credit-for-homicide-drop-during-romero-beatification.

Garcia, Carlos. "Tracing the History of Failed Gang Policies in US, Northern Triangle." Insight Crime, December 3, 2015. http://www insightcrime.org/newsanalysis/tracing-the-history-of-failed-gang-policies-in-us-northern-triangle.

Gélineau, François, and Elizabeth J. Zechmeister. "La Culture Politique de La Démocratie En Haïti et Dans Les Amériques 2014: La Gouvernance Démocratique Au Fil Des 10 Ans Du Baromètre Des Amériques.” LAPOP, Americas Barometer, Vanderbilt university, April 2016.

George, Alexander L., and Andrew Bennett. Case Studies and Theory Development in the Social Sciences. Cambridge: The MIT Press, 2005.

Gerring, John. Case Study Research: Principles and Practices. 1st ed. Cambridge ; New York: Cambridge University Press, 2007.

Gleditsch, Nils Petter. "Peace and Democracy." In Encyclopedia of Violence, Peace, and Conflict, edited by Lester Kurtz, 1:643-52, 1999.

Goldstein, Daniel M., and Enrique Desmond Arias. Violent Democracies in Latin America. Duke University Press, 2010.

Gonzales, Elizabeth. "2014 Election Blog: Haiti's October Legislative Elections in Doubt.” Americas Society/Council of the Americas, July 15, 2014. http://www.ascoa.org/blogs/2014-election-blog-haitis-october-legislative-elections-doubt.

Gonzalez, Douglas. “28 Mil 130 Pandilleros Registra La Policía En El 2011.” Periódico Digital La Página, December 21, 2011.

http://www.lapagina.com.sv/nacionales/60115/2011/12/21/28-mil-130pandilleros-registra-la-policia-en-el-2011.

Goodhand, Jonathan. "Corrupting or Consolidating the Peace? The Drugs Economy and Post-Conflict Peacebuilding in Afghanistan." International Peacekeeping 15, no. 3 (June 2008): 405-23.

Government of Canada. "Canadian Guidelines for Security System Reform.” Government of Canada, 2013.

Government of El Salvador, and Frente Farabundo Martí para la Liberacíon Nacional. "El Salvador Peace Agreement (Chapultepec).” Mexico, January 16, 1992. http://peacemaker.un.org/elsalvador-chapultepec92. 
Government of Haiti. "Haiti Earthquake PDNA: Assessment of Damage, Losses, General and Sectoral Needs." Governement of Haiti, March 24, 2010. http://www.gafspfund.org/sites/gafspfund.org/files/Documents/Haiti_PDNA.pdf.

_ — - Loi relative à la Police nationale, Pub. L. No. Monitor nº103 (1994). https://www.oas.org/juridico/MLA/fr/hti/fr_hti_mla_gen_police.html.

- - - . "Premier Rapport de La Mise En Oeuvre Du Plan de Développement de La Police Nationale d'Haïti 2012-2016 (Septembre 2012-2016)." Governement of Haiti, February 6, 2013.

Grabendorff, Wolf. "Limited Security Sector Reform in Colombia.” In Security Sector Reform in Challenging Environments, edited by Hans Born and Albrecht Schnabel, 69-86. Münster: LIT, 2009.

Gros, Jean-Germain. "Towards a Taxonomy of Failed States in the New World Order: Decaying Somalia, Liberia, Rwanda and Haiti." Third World Quarterly 17, no. 3 (September 1, 1996): 455-71.

Gutiérrez, Edward. "PNC Anuncia Caza de 309 Líderes de Clicas.” El Diario de Hoy, October 24, 2003. http://archivo.elsalvador.com/noticias/2003/10/24/nacional/nacio3.html.

Gutiérrez, Norma C. “El Salvador: Gang Violence.” Washington, D.C.: U.S. Law Library of Congress, December 2012.

Guyler Delva, Joseph, and Daniel Dieujuste. "La Nouvelle Force Militaire Haïtienne Maintenant Effective, Lance Ses Opérations." Haitian Caribbean News Network, February 13, 2014. http://hcnn.ht/fr/2014_01/aide_et_developpement/238/Lanouvelle-force-militaire-haïtienne-maintenant-effective-lance-ses-opérations.htm.

Halling, Matt, and Blaine Bookey. "Peacekeeping in Name Alone: Accountability for the United Nations in Haiti Comment." Hastings International and Comparative Law Review 31, no. 1 (2008): 461-86.

Hammond, Guy. "Saving Port-Au-Prince: United Nations Efforts To Protect Civilians In Haiti In 2006-2007.” Washington, D.C.: The Henry L. Stimson Center, June 2012. http://www.stimson.org/content/saving-port-au-prince-united-nationsefforts-protect-civilians-haiti-2006\%E2\%80\%932007.

Herbst, Jeffrey. States and Power in Africa. 1st ed. Princeton, N.J: Princeton University Press, 2000.

Holland, Alisha C. "Right on Crime?: Conservative Party Politics and Mano Dura Policies in El Salvador.” Latin American Research Review 48, no. 1 (2013): 4467. doi:10.1353/lar.2013.0009.

Hoppert-Flämig, Susan. "A Salvadoran Turnaround? The FMLN's Response to Citizen Security Needs." In Repensando La Seguridad Desde Una Perspective Democatica Y de Derechos Humanos. Vienna, 2012. http://www.academia.edu/2092714/A_Salvadoran_Turnaround_The_FMLNs_Res ponse_to_Citizen_Security_Needs. 
Horton, Lynn. "After the Earthquake: Gender Inequality and Transformation in PostDisaster Haiti." Gender \& Development 20, no. 2 (July 1, 2012): 295-308. doi:10.1080/13552074.2012.693284.

Human Rights Watch. "World Report 1994: Haiti," 1994. https://www.hrw.org/reports/1994/WR94/Americas-06.htm\#P330_164164.

Human Rights Watch, and Washington Office for Latin America. "Haiti: The Human Rights Record of the Haitian National Police." Human Rights Watch, January 1997.

Hume, Mo. "Mano Dura: El Salvador Responds to Gangs." Development in Practice 17, no. 6 (2007): 739-51.

Institute for Criminal Policy Research. "Haiti I World Prison Brief." World Prison Brief, 2015. http://www.prisonstudies.org/country/haiti.

Institute for Democracy and Electoral Assistance. "Vote Turnout Data for Haiti," October 5, 2011. http://www.idea.int/vt/countryview .cfm?CountryCode=HT.

Inter-American Commission on Human Rights. "Preliminary Observations in the Visit to El Salvador by the Office of the Rapporteur on the Rights of Persons Deprived of Liberty. Annex to Press Release 104/10." Organization of American States, October 20, 2010.

http://www.cidh.oas.org/Comunicados/English/2010/ANNEX\%20104-10.pdf.

International Crisis Group. “A New Chance for Haiti?” Latin America/Caribbean Report $\mathrm{N}^{\circ} 10$, November 18, 2004.

- - - "Haiti: Security and Reintegration of the State." Latin America/Caribbean Briefing. Port-au-Prince/Brussels, October 30, 2006.

- - _ . Keeping Haiti Safe: Justice Reform.” Latin America/Caribbean Briefing. Portau-Prince/Brussels: International Crisis Group, October 27, 2011.

- - _ "Keeping Haiti Safe: Police Reform.” Latin America/Caribbean Briefing. Portau-Prince/Brussels: International Crisis Group, September 8, 2011.

- - - "Reforming Haiti's Security Sector." Latin America/Caribbean Report N²8. New York: International Crisis Group, September 18, 2008.

- - - "Spoiling Security in Haiti." Latin America/Caribbean Briefing. Port-auPrince/Brussels: International Crisis Group, May 31, 2005. https://www .crisisgroup.org/latin-america-caribbean/haiti/spoiling-security-haiti.

- - - . "Towards a Post-MINUSTAH Haiti: Making an Effective Transition." Latin America/Caribbean Report $\mathrm{N}^{\circ} 44$. New York: International Crisis Group, August $2,2012$.

INURED. "Voices from the Shanties: A Post-Earthquake Rapid Assessment of Cité Soleil, Port-Au-Prince," March 2010. http://www.inured.org/uploads/2/5/2/6/25266591/voices_from_the_shanties.pdf. 
IUDOP. "La Situación de La Seguridad Y La Justicia 2009-2014: Entre Expectativas de Cambio, Mano Dura Militar Y Treguas Pandilleras." Instituto Universitario de Opinión Publica, Universidad Centroamericana “José Simeón Cañas.,” 2014.

Jackson, Paul, ed. Handbook of International Security and Development. Cheltenham, UK ; Northampton, MA, USA: Edward Elgar Pub, 2015.

- - - "Security Sector Reform and State Building." Third World Quarterly 32, no. 10 (2011): 1803-1822.

Jackson, Stephen. "Fortunes of War: The Coltan Trade in the Kivus." In Power, Livehood and Conflict: Case Studies in Political Economy Analysis for Humanitarian Action, edited by S. Collinson, Humanitarian Policy Group, Overseas Development Institute. London, 2003. http://www.refworld.org/docid/4a5b32c20.html.

Jaffe, Rivke. "The Hybrid State: Crime and Citizenship in Urban Jamaica." American Ethnologist 40, no. 4 (November 1, 2013): 734-48. doi:10.1111/amet.12051.

Kinosian, Sarah, Angelika Albaladejo, and Lisa Haugaard. "El Salvador's Violence: No Easy Way Out.” Security Assistance Monitor, August 2016.

Kivland, Chelsey L. "A Report on the Recent Changes in Perceptions of Security and Social Services in Bel Air, Haiti." Viva Rio Evaluation Project. Small Arms Survey, September 2009.

- - - . "Unmaking the State in 'Occupied' Haiti." PoLAR: Political and Legal Anthropology Review 35, no. 2 (November 1, 2012): 248-70. doi:10.1111/j.15552934.2012.01202.x.

Knight, M. "Security Sector Reform, Democracy, and the Social Contract: From Implicit to Explicit." Journal of Security Sector Management 7, no. 1 (2009): 20.

Kolbe, Athena R. "Revisiting Haiti's Gangs and Organized Violence.” Discussion Paper. Rio de Janeiro: Humanitarian Action in Situations other than War, May 2013.

Kolbe, Athena R, and Royce A Hutson. "Human Rights Abuse and Other Criminal Violations in Port-Au-Prince, Haiti: A Random Survey of Households." The Lancet 368, no. 9538 (2006): 864-73.

Kolbe, Athena R, Royce A Hutson, Harry Shannon, Eileen Trzcinski, Bart Miles, Naomi Levitz, Marie Puccio, Leah James, Jean Roger Noel, and Robert Muggah. "Mortality, Crime and Access to Basic Needs before and after the Haiti Earthquake: A Random Survey of Port-Au-Prince Households." Medicine, Conflict, and Survival 26, no. 4 (December 2010): 281-97.

Kolbe, Athena R., and Robert Muggah. "Securing the State: Haiti Before and After the Earthquake.” In Small Arms Survey 2011: State of Security, edited by Small Arms Survey, Small Arms Survey. Geneva, 2011.

- - - . "The Economic Costs of Violent Crime in Urban Haiti: Results from Monthly Household Surveys, August 2011-July 2012." Strategic Note. Rio de Janeiro: Igarapé Institute, September 2012. 
Kolbe, Athena R, Robert Muggah, Royce A Hutson, Leah James, Marie Puccio, Eileen Trzcinski, Harry Shannon, Naomi Levitz, and Roger Jean Noel. "Assessing Needs After the Quake: Preliminary Findings from a Randomized Survey of Port-AuPrince Households." University of Michigan/Small Arms Survey, April 2010.

Kovats-Bernat, J. Christopher. Sleeping Rough in Port-Au-Prince : An Ethnography of Street Children and Violence in Haiti. Gainesville, FL: University Press of Florida, 2006.

Kristi Samuels. Rule of Law Reform in Post-conflict Countries: Operational Initiatives and Lessons Learnt (2006).

Kyed, Helene Maria. "Legal Pluralism and International Development Interventions." Journal of Legal Pluralism and Unofficial Law 63 (2011): 1-23.

Labrador, Gabriel, and José Luis Sanz. "Viceministro de Seguridad, Henry Campos, Renuncia Al Cargo." Elfaro.net, January 31, 2012. http://www.elfaro.net/es/201201/noticias/7422/Viceministro-de-Seguridad-HenryCampos-renuncia-al-cargo.htm.

Ladutke, Lawrence Michael. "Expression for and against the Vigilante Death Squad Sombra Negra." Southwestern Journal of Law and Trade in the Americas 8 (2002 2001): 283.

Laguerre, Michel. "The Place of Voodoo in the Social Structure of Haiti." Caribbean Quarterly 19, no. 3 (September 1, 1973): 36-50.

Laguerre, Michel S. The Military and Society in Haiti. Knoxville: University of Tennessee Press, 1993.

Lake, David A., and Donald S. Rothchild. The International Spread of Ethnic Conflict: Fear, Diffusion, and Escalation. Princeton, N.J: Princeton University Press, 1998.

Latinobarómetro. "Problema Más Importante En El País, El Salvador 2004-2015." Latinobarómetro Database, 2015. http://www.latinobarometro.org/latOnline.jsp.

Leovy, Jill. Ghettoside: A True Story of Murder in America. New York: Spiegel \& Grau, 2015.

Levin, Mark, and Georgy Satarov. "Corruption and Institutions in Russia." European Journal of Political Economy 16, no. 1 (March 2000): 113-32. doi:10.1016/S0176-2680(99)00050-6.

Li, Geoffrey. "Private Security and Public Policing." Statistics Canada, March 12, 2009. http://www.statcan.gc.ca/pub/85-002-x/2008010/article/10730-eng.htm.

Libecap, Gary D. "Contracting for Mineral Rights." In Contracting for Property Rights, 29-50. Cambridge ; New York: Cambridge University Press, 1989.

Lopez, Juan Carlos. "Funes Responde Al Fiscal General Que Llamó 'hipócrita' el Pacto Entre Maras En El Salvador.” CNN Español, April 19, 2013. http://cnnespanol.cnn.com/2013/04/19/mauricio-funes-responde-al-fiscal-generalque-llamo-hipocrita-el-pacto-entre-pandillas-en-el-salvador/. 
Maguire, Robert. "Providing Justice in Haiti.” Peacebrief 122. Washington, D.C.: United States Institute of Peace (USIP), April 4, 2012.

Maguire, Robert, and Courtney McCreesh. "The Challenge of Keeping Haitians Safe." Peacebrief. Washington, D.C.: United States Institute of Peace (USIP), June 13, 2011.

Mampilly, Zachariah Cherian. Rebel Rulers: Insurgent Governance and Civilian Life during War. Ithaca, NY: Cornell University Press, 2011.

Mannitz, Sabine. "From Paternalism to Facilitation: SSR Shortcomings and the Potential of Social Anthropological Perspectives." International Peacekeeping 21, no. 2 (March 15, 2014): 269-85. doi:10.1080/13533312.2014.910403.

Marroquín. “Pandillas Cambian Forma de Extorsionar a Sus Víctimas.” El Diario de Hoy. December 15, 2011.

http://archivo.elsalvador.com/mwedh/aspnet/chkDispositivo.aspx?idart=6475206 \&idcat $=47859 \& \mathrm{t}=$ nota $\& \mathrm{~m}=\mathrm{aHR} 0 \mathrm{cDovL} 2 \mathrm{Fy} Y 2 \mathrm{hpdm} 8 \mathrm{uZWxzYWx} 2 \mathrm{YWRvci5jb2}$ 0vbXdlZGgvbm90YS9ub3RhX2NvbXBsZXRhLmFzcD9pZENhdD00Nzg1OSZ pZEFydD02NDc1MjA2\&sin=NOWEBCACHE.

Martelly, Michel. "Haiti: Now Open to Foreign Investors." The Huffington Post, February 8, 2012. http://www.huffingtonpost.ca/michel-martelly/haitiinvest_b_1260540.html.

Martinez, Carlos. "Gobierno Da Un Paso Para Asumir Responsabilidad Sobre La Tregua." El Faro. April 22, 2013. http://www .elfaro.net/es/201304/noticias/11796/.

- - - . "Ilopango Contra Su Sombra.” El Faro. March 18, 2013. http://www.salanegra.elfaro.net/es/201303/cronicas/11434/?st-full_text=1.

Martínez, Carlos, and José Luis Sanz. “III. Democráticos Homies.” Elfaro.net. April 7, 2014. http://www.salanegra.elfaro.net/es/201404/cronicas/15198/IIIDemocráticos-homies.htm.

Martinez, Carlos, and José Luis Sanz. "La Nueva Verdad Sobre La Tregua Entre Pandillas." Elfaro.net. September 11, 2012. http://www.salanegra.elfaro.net/es/201209/cronicas/9612/La-nueva-verdad-sobrela-Tregua-entre-pandillas.htm.

_- _. "Tiembla La Tregua En Ilopango.” El Faro. September 7, 2013. http://www .elfaro.net/es/201309/noticias/13231/.

Martínez, Oscar, Carlos Martínez, Sergio Arauz, and Efren Lemus. "Gobierno Negoció Con Pandillas Reducción de Homicidios.” El Faro. March 14, 2012. http://www.elfaro.net/es/201203/noticias/7985/.

Matalon, Lorne. "Haitian Police Chief Battles Widespread Corruption.” NPR.org. National Public Radio, January 10, 2006. http://www.npr.org/templates/story/story.php?storyId=5226454.

Mcleary, Paul. “More U.S. Troops Bound for Afghanistan, As Marines, Commandos, Arrive In Syria.” The Cable (Foreign Policy), March 9, 2017. 
https://foreignpolicy.com/2017/03/09/more-us-troops-afghanistan-marines-syriacommandos-iraq/.

Meagher, Kate. "The Strength of Weak States? Non-State Security Forces and Hybrid Governance in Africa." Development and Change 43, no. 5 (2012): 1073-1101. doi:10.1111/j.1467-7660.2012.01794.x.

Médecins sans frontières. "Violence, Mortality and Access to Health Care in Cité Soleil, Port-Au-Prince, Haiti. Results of an Epidemiological Survey." Médecins sans frontières, March 2008.

Melara Minero, Licide Michelle. "Los Servicios de Seguridad Privada En El Salvador." Estudios Centroamericanos, no. 636 (October 2001): 907-32.

Meléndez, Cristian. “750 Pandilleros Dentro Del Programa PATI.” La Prensa Grafica, July 22, 2013. http://www.laprensagrafica.com/750-pandilleros-dentro-delprograma-pati.

- - - . "Pandilleros Provocan Que Familias Dejen Colonia." La Prensa Gráfica. June 21, 2013. http://www .laprensagrafica.com/pandilleros-provocan--que-familiasdejen-colonia.

Meléndez, William. "La Cifra Que Nos Sale Es 60,000 Pandilleros En La Mitad de Municipios." La Prensa Gráfica. May 1, 2012. http://www.laprensagrafica.com/el-salvador/judicial/260717-la-cifra-que-nossale-es-60000-pandilleros-en-la-mitad-de-municipios.html.

Mendelson-Forman, Johanna. "Security Sector Reform in Haiti." International Peacekeeping 13, no. 1 (2006): 14-27.

Menkhaus, Ken. “State Failure and Ungoverned Space.” In Ending War, Consolidating Peace: Economic Perspectives, edited by Mats Berdal and Achim Wennmann, 50:171-88. Adelphi Series. New York: Routledge, 2010.

Merilus, Jean-Yves. "Rural Development: The Economic Potentials of Haiti's 'Lakou' System.” Focus on Geography 58, no. 1 (January 1, 2015): 36-45. doi:10.1111/foge.12047.

Ministerio de Justicia y Seguridad Publica. "Política Nacional de Justicia, Seguridad Publica Y Convivencia.” El Salvador, 2012. http://www .aecid.org.sv/wpcontent/uploads/2014/01/Poli\%C2\%B4tica-Nacional-de-Justicia21.pdf?82a9e7.

MINUSTAH. "État d'Avance de La Mise En Oeuvre Du Plan de Développement de La PNH 2012-2016 (Septembre 2012-Décembre 2013),” N.D.

Mobekk, E. "International Involvement in Restructuring and Creating Security Forces: The Case of Haiti" 12, no. 3 (September 1, 2001): 97-114.

Moe, Louise Wiuff. "Hybrid and 'Everyday' Political Ordering: Constructing and Contesting Legitimacy in Somaliland." Journal of Legal Pluralism and Unofficial Law, no. 63 (2011): 143-77. 
Montgomery, Tommie Sue. "Getting to Peace in El Salvador: The Roles of the United Nations Secretariat and ONUSAL." Journal of Interamerican Studies and World Affairs 37, no. 4 (December 1, 1995): 139-72. doi:10.2307/166249.

Moodie, Ellen. El Salvador in the Aftermath of Peace: Crime, Uncertainty, and the Transition to Democracy. The Ethnography of Political Violence. Philadelphia: University of Pennsylvania Press, 2010.

Morán, Gloria. "Pandilleros de Ilopango Firman Acta Por La Paz." ContraPunto Diario El Salvador. January 22, 2013. http://www.contrapunto.com.sv/archivo2016/violencia/pandilleros-de-ilopangofirman-acta-por-la-paz.

Morawetz, Nancy. "Understanding the Impact of the 1996 Deportation Laws and the Limited Scope of Proposed Reforms." Harvard Law Review 113, no. 8 (2000): 1936-62. doi:10.2307/1342314.

Muggah, Robert. "Securing Haiti’s Transition: Reviewing Human Insecurity and the Prospect for Disarmament, Demobilization, and Reintegraiton." Occasional Paper. Geneva: Small Arms Survey, October 2005.

- - - "The Effects of Stabilisation on Humanitarian Action in Haiti." Disasters 34 (2010): S444-63. doi:10.1111/j.1467-7717.2010.01205.x.

Muggah, Robert, and Athena R Kolbe. "In Haiti, Violence amid the Rubble." The Globe and Mail. March 5, 2012. http://www.theglobeandmail.com/commentary/in-haitiviolence-amid-the-rubble/article550656/.

Muggah, Robert, and Keith Krause. "Closing the Gap Between Peace Operations and Post-Conflict Insecurity: Towards a Violence Reduction Agenda." International Peacekeeping 16, no. 1 (2009): 136-50. doi:10.1080/13533310802485617.

Mukhopadhyay, Dipali. "Disguised Warlordism and Combatanthood in Balkh: The Persistence of Informal Power in the Formal Afghan State." Conflict, Security \& Development 9, no. 4 (December 2009): 535-64. doi:10.1080/14678800903345812.

- - - Warlords, Strongman Governors, and the State in Afghanistan. Cambridge: Cambridge University Press, 2014.

Murcia, Diego. "15 Pasajeros Muertos En Ataque a Microbuses En Mejicanos.” Elfaro.net, February 21, 2010. http://www .elfaro.net/es/201006/noticias/1967/15pasajeros-muertos-en-ataque-a-microbuses-en-Mejicanos.htm.

Nathan, Laurie. "No Ownership, No Commitment: Local Ownership of Security Sector Reform: A Guide for Donors.” United Kingdom: University of Birmingham, 2007.

"NATO and Afghanistan." North Atlantic Treaty Organization, May 7, 2015. http://www.nato.int/cps/en/natohq/topics_8189.htm.

North, Douglass C. "Institutions.” Journal of Economic Perspectives 5, no. 1 (1991): 97112. 
O’Brien, Jason. "Haiti Special Report: Corruption Means Many Prisoners Wait Years for Trials." Independent.ie, February 15, 2014. http://www.independent.ie/worldnews/americas/haiti-special-report-corruption-means-many-prisoners-wait-yearsfor-trials-30011805.html.

Observatorio metropolitano para la prevencion de la violencia. "Analisis de Delitos En El AMSS 2010." Observatorio metropolitano para la prevencion de la violencia, 2011.

Odell, John S. "Case Study Methods in International Political Economy." International Studies Perspectives 2, no. 2 (May 1, 2001): 161-76. doi:10.1111/15283577.00047.

OECD. Helping Prevent Violent Conflict. Paris: Organisation for Economic Co-operation and Development, 2001. http://www.oecdilibrary.org/content/book/9789264194786-en.

OECD-DAC. The OECD DAC Handbook on Security System Reform (SSR): Supporting Security and Justice. Paris: Organisation for Economic Co-operation and Development, 2007.

OECD-DAC, A. Security Sector Reform and Governance. DAC Guidelines and Reference Series. Paris: OECD Publishing, 2005.

Oxford English Dictionary. “Order, N.” OED Online. Oxford University Press, N.D.

Paris, Roland. At War's End: Building Peace After Civil Conflict. Cambridge, UK ; New York: Cambridge University Press, 2004.

Perito, Robert M. "Police in Peace and Stability Operations: Evolving US Policy and Practice." International Peacekeeping 15, no. 1 (2008): 51-66. doi:http://dx.doi.org.proxy.library.carleton.ca/10.1080/13533310701879910.

Pierre, Yves-François, and Isabelle Fortin. "La Réforme de La Police Nationale et La Construction Démocratique En Haïti" Revue canadienne d'études du développement, no. 1 (2011): 64-78.

PNC. "Plan Estratégico Institutional 2009-2014: Seguridad Y Tranquilidad, Con Participacion Social." Policia Nacional Civil de El Salvador, February 2010. http://www.transparencia.pnc.gob.sv/portal/page/portal/transparencia/OIR/Mecani smo_participacion_ciudadana/PEI_2009_-_2014.pdf.

Popkin, Margaret. "Building the Rule of Law in Post-War El Salvador." In EL Salvador: Implementation of the Peace Accords, edited by Margarita S. Studemeister, 1019. Washington, D.C.: United States Institute of Peace, 2001.

- - - . Peace without Justice: Obstacles to Building the Rule Oflaw in El Salvador. University Park, Pa: Pennsylvania State University Press, 2000.

Posen, Barry R. “The Security Dilemma and Ethnic Conflict.” Survival 35, no. 1 (1993): $27-47$. 
PRESIDENT PREVAL “DESARMEMENT OU LA MORT,” 2006.

https://www.youtube.com/watch?v=KM8ksNBHm1A\&feature=youtube_gdata_pl ayer.

Presto, Susan. "Sexual Assaults in Haitian Camps Prompt Security Enhancements." Voice of America, March 22, 2010. http://www.voanews.com/a/sexual-assaultsin-haitian-camps-prompt-security-enhancements-88857522/163847.html.

Radio Kiskeya. "Grand-Ravine : Le Chef de Gang Doy Junior Assassiné, Trois Mois Après Son Prédécesseur «Ti Kenkenn »." Radio Kiskeya, October 19, 2014. http://www.radiokiskeya.com/spip.php?article10245.

Reno, William. "Protectors and Predators: Why Is There a Difference among West African Militias?" In Fragile States and Insecure People? Violence, Security and Statehood in the Twenty-First Century, edited by Louise R. Andersen, Bjørn Møller, and Finn Stepputat. Palgrave Studies in Governance, Security and Development. New York: Palgrave MacMillan, 2007.

- - - . "Understanding Criminality in West African Conflicts." International Peacekeeping 16, no. 1 (February 1, 2009): 47-61. doi:10.1080/13533310802485542.

République d'Haïti. "5ème Rapport de Mise En Oeuvre Du Plan de Développement de La PNH 2012-2016.” Port-au-Prince, September 2015. http://www.slideshare.net/jaimevigil108/5eme-rapport-plan-de-developpementpnh-2012-2016-final.

RESDAL. "El Salvador." In Public Security Index: Central America, 44-65. Buenos Aires, 2013. http://www.resdal.org/ing/libro-seg-2013/el-salvador-index-2013ing.pdf.

Ribando Seelke, Clare. "Gangs in Central America." CRS Report for Congress. Washington, DC: Congress Research Service, January 3, 2011.

Ribeiro, Eduardo, Doriam Borges, and Ignacio Cano. "Calidad de Los Datos de Homicidio En América Latina." Laboratorio de Analisis de la Violencia Universidad do Estado do Rio de jANEIRO, 2015.

Risse, Thomas. Governance Without a State?: Policies and Politics in Areas of Limited Statehood. Columbia University Press, 2011.

RNDDH. "Illicit Drug Trafficking: The Government of Martelly/Lamothe Makes Every Effort to Protect Drug Traffickers close to Power," September 19, 2013. http://rnddh.org/content/uploads/2013/09/Rapport-Drogue-Sud-18-sep-2013AN.pdf.

- - - . "Rapport D'enquête Sur La Situation de Tension À l'Arcahaie." Port-au-Prince: RNDDH, October 14, 2015. http://rnddh.org/content/uploads/2015/10/8Arcahaie-14-octobre-20151.pdf.

- - - "Rapport Sur Les Événements Survenus À Cité Soleil Le 16 Octobre 2015." Port-au-Prince: RNDDH, November 20, 2015. http://rnddh.org/content/uploads/2015/11/9-Cit\%C3\%A9-Soleil-Nov-2015.pdf. 
Robbins, Seth. "El Salvador's Military: Arms Dealer to the Maras?” Insight Crime, June 16, 2014. http://www.insightcrime.org/news-analysis/el-salvadors-military-armsdealer-to-the-maras.

Robles, Frances. “Haitian Leader's Power Grows as Scandals Swirl.” The New York Times, March 16, 2015.

http://www.nytimes.com/2015/03/17/world/americas/haitian-president-tightensgrip-as-scandal-engulfs-circle-of-friends.html.

Rodgers, Dennis, and Robert Muggah. "Gangs as Non-State Armed Groups: The Central American Case.” Contemporary Security Policy 30, no. 2 (2009): 301-17.

Rodriguez, Carmen, and Israel Serrano. "Municipios Santuarios" definirán Segunda Fase de Tregua Entre Pandillas." Diario digital de noticias de El Salvador. La Pagina, November 23, 2012.

http://www.lapagina.com.sv/nacionales/74210/2012/11/23/Municipios-santuariosdefiniran-segunda-fase-de-tregua-entre-pandillas.

Rodríguez, Nestor, and Jacqueline Maria Hagan. "Fractured Families and Communities: Effects of Immigration Reform in Texas, Mexico, and El Salvador." Latino Studies 2, no. 3 (December 27, 2004): 328-51. doi:10.1057/palgrave.1st.8600094.

Rosenberg, Matthew, and Michael D. Shear. "In Reversal, Obama Says U.S. Soldiers Will Stay in Afghanistan to 2017." The New York Times, October 15, 2015. http://www.nytimes.com/2015/10/16/world/asia/obama-troop-withdrawalafghanistan.html.

Rotberg, Robert I. State Failure and State Weakness in a Time of Terror. Washington, DC: Brookings Institution Press, 2003.

- - - "The Failure and Collapse of Nation-States; Breakdown, Prevention and Repair.” In When States Fail: Causes and Consequences, edited by Robert I. Rotberg, 1-49. Princeton, N.J: Princeton University Press, 2004.

Russett, Bruce. Grasping the Democratic Peace: Principles for a Post-Cold War World. Princeton University Press, 1994.

Santacruz Giralt, Maria L., and Alberto Concha-Eastman. Barrios Adentro: La Solaridad Violenta de Las Pandillas. San Salvador, El Salvador: Instituto Universitario de Opinion Publica (UCA), 2001.

Santos, Jessel. "Fiscal: La Tregua Es Una 'negociación Hipócrita.'” La Prensa Gráfica. April 18, 2013. http://www.laprensagrafica.com/fiscal--la-tregua-es-una-negociacion-hipocrita-.

_ - - . "Nuevo Ministro de Seguridad Desliga a Gobierno de Tregua." La Prensa Gráfica, May 30, 2013. http://www.laprensagrafica.com/nuevo-ministro-deseguridad-desliga-a-gobierno-de-tregua.

Santos, Jessel, and Ricardo Flores. "Sin Claridad Fondos Para 'santuarios." La Prensa Gráfica, January 22, 2013. http://www.laprensagrafica.com/sin-claridad-fondospara--santuarios-. 
Santos, Jessel, and Gabriela Melara. "Douglas Moreno Ante Juez Por Violencia Intrafamiliar." La Prensa Gráfica. June 10, 2013.

http://www.laprensagrafica.com/douglas-moreno-ante-juez-por-violenciaintrafamiliar.

Santos, Jessel, and Marcos Salguero. "PNC: Pandillas Con Tácticas Militares.” La Prensa Gráfica, April 8, 2014. http://www.laprensagrafica.com/2014/04/08/pncpandillas-con-tacticas-militares.

Sanz, José, and Carlos Martinez. "Exviceministro de Seguridad Negoció En Persona Con Líderes Pandilleros.” El Faro, July 27, 2013. http://www.salanegra.elfaro.net/es/201307/cronicas/12785/.

Savage, Sam. "El Salvador Death Squads Targeting Criminals: Church.” Reuters. June $15,2006$.

http://www.redorbit.com/news/international/539971/el_salvador_death_squads_ta rgeting_criminals_church/.

Savenije, Wim, and Chris van der Borgh. "Anti-Gang Policies and Gang Responses in the Northern Triangle." The Broker - Connecting Worlds of Knowledge. Accessed March 7, 2016. http://www .thebrokeronline.eu/Articles/Anti-gang-policies-andgang-responses-in-the-Northern-Triangle.

Scheye, Eric. "Realism and Pragmatism in Security Sector Development." United States Institute of Peace Special Report. Washington, D.C.: United States Institute of Peace (USIP), October 2010.

Scheye, Eric, and Gordon Peake. "Unknotting Local Ownership.” In After Intervention: Public Security Management in Post-Conflit Societies. From Intervention to Sustainable Local Ownership, edited by Anja H. Ebnöther and Philipp H. Fluri. Vienna: National Defense Academy and Bureau for Security Policy, 2005.

Schnabel, Albrecht, and Albert Born. "Security Sector Reform: Narrowing the Gap between Theory and Practice." SSR Paper. Geneva: The Geneva Centre for the Democratic Control of Armed Forces (DCAF), 2011.

Schroeder, Ursula C., and Fairlie Chappuis. "New Perspectives on Security Sector Reform: The Role of Local Agency and Domestic Politics." International Peacekeeping 21, no. 2 (March 15, 2014): 133-48. doi:10.1080/13533312.2014.910401.

Schroeder, Ursula C., Fairlie Chappuis, and Deniz Kocak. "Security Sector Reform and the Emergence of Hybrid Security Governance.” International Peacekeeping 21, no. 2 (March 15, 2014): 214-30. doi:10.1080/13533312.2014.910405.

Schuberth, Moritz. "A Transformation from Political to Criminal Violence? Politics, Organised Crime and the Shifting Functions of Haiti's Urban Armed Groups." Conflict, Security \& Development 15, no. 2 (March 15, 2015): 169-96. doi:10.1080/14678802.2015.1030950. 
- - - " "Growing the Grassroots or Backing Bandits? Dilemmas of Donor Support for Haiti's (UN)Civil Society." Journal of Peacebuilding \& Development 11, no. 1 (January 2, 2016): 93-98. doi:10.1080/15423166.2016.1146565.

Sedra, Mark. "Security Sector Reform in Afghanistan and Iraq: Exposing a Concept in Crisis." Journal of Peacebuilding \& Development 3, no. 2 (2007): 7-23.

- - - "Towards Second Generation Security Sector Reform." In The Future of Security Sector Reform, edited by Mark Sedra, Centre for International Governance Innovation., 102-16. Waterloo (On), 2010.

Segura, Edwin. "El Salvador Con Más Homicidios En C. A.” La Prensa Gráfica. January 3, 2016. http://www.laprensagrafica.com/2016/01/03/el-salvador-con-mashomicidios-en-c-a.

- - - “"Tregua, Entre Dudas.” La Prensa Gráfica. March 7, 2013. http://www.laprensagrafica.com/Tregua--entre-dudas.

Semple, Kirk. "Haiti's Struggle to Restore the Rule of Law." Haiti Democratic Project, March 30, 2004.

Sénat, Jean Daniel. "Le Présumé Chef de Gang Gabriel Jean Pierre Appréhendé À Cité Soleil." Le Nouvelliste, September 4, 2014.

http://lenouvelliste.com/lenouvelliste/article/135390/Le-presume-chef-de-gangGabriel-Jean-Pierre-apprehende-a-Cite-Soleil.html.

Skaperdas, Stergios. "The Political Economy of Organized Crime: Providing Protection When the State Does Not." Economics of Governance 2, no. 3 (November 2001): 173-202. doi:10.1007/PL00011026.

Skarbek, David. The Social Order of the Underworld: How Prison Gangs Govern the American Penal System. 1 edition. Oxford: Oxford University Press, 2014.

Smutt, Marcela, and Jenny Lisette Miranda. El Fénomeno de Las Pandillas En El Salvador. San Salvador, El Salvador: UNICEF-FLACSO, 1998.

Soto, Alvaro de. "Foreword." In Political Economy of Statebuilding; Power after Peace, edited by Mats Berdal and Dominik Zaum, Routledge., xvii-xx. Routledge Studies in Intervention and Statebuilding. London ; New York, 2012.

Stanley, William. "Building New Police Forces in El Salvador and Guatemala: Learning and Counter-learning." International Peacekeeping 6, no. 4 (1999): 113-34. doi:10.1080/13533319908413801.

- - - . The Protection Racket State: Elite Politics, Military Extortion, and Civil War in El Salvador. Philadelphia: Temple University Press, 1996.

Stedman, Brooke. "Security After the Quake? Addressing Violence and Rape in Haiti." Peacebrief. Washington, D.C.: United States Institute of Peace (USIP), January 7 , 2011. https://www.usip.org/sites/default/files/PB73-

Security_After_the_Quake.pdf. 
Stone, Hannah. "Next Phase of Salvador Gang Truce: Peace Zones." Insight Crime, November 23, 2012. http://www.insightcrime.org/news-briefs/next-phasesalvador-gang-truce-peace-zones.

Taft-Morales, Maureen. "Haiti Under President Martelly: Current Conditions and Congressional Concerns.” Washington, D.C.: Congress Research Service, December 23, 2015.

- - - ."Haiti's National Elections: Issues, Concerns, and Outcome." CRS Report for Congress. Washington, D.C.: Congress Research Service, July 18, 2011.

Tahani, Mustafa. "Insecurity through Security Sector Reform." Ethnographic Papers. School of Oriental and African Studies, June 2015.

Taylor, Margaret, and Alexander Aleinikoff. "Deportation of Criminal Aliens: A Geopolitical Perspective.” Washington, D.C.: Inter-American Dialogue, June 1998

Thale, Geoff. "Las Pandillas Juveniles Centroamericanas Y La Repuestas de 'Mano Dura."” Quorum, no. 16 (2006): 51-61.

Thale, Geoff, and Elsa Falkenburger. "Youth Gangs in Central America. Issues on Human Rights, Effective Policing, and Prevention.” WOLA Special Report. Washington, DC: Washington Office on Latin America, November 2006.

The World Bank. "Haiti: WBG Report Calls for New Social Contract to Promote Opportunities for All.” Text/HTML. World Bank, September 22, 2015. http://www.worldbank.org/en/news/press-release/2015/09/22/haiti-wbg-reportcalls-for-new-social-contract-to-promote-opportunities-for-all.

Thurber, Ches. "Militias as Sociopolitical Movements: Lessons from Iraq's Armed Shia Groups." Small Wars \& Insurgencies 25, no. 5-6 (September 3, 2014): 900-923.

Tilly, Charles. Coercion, Capital and European States: AD 990 - 1992. Revised. Hoboken, N.J.: Wiley-Blackwell, 1992.

Torre, Verónica de la, and Alberto Martín Alvarez. "Violencia, Estado de Derecho Y Políticas Punitivas En América Central." Perfiles Latinoamericanos 19, no. 37 (June 2011): 33-50.

Tsai, Lily L. "Friends or Foes? Nonstate Public Goods Providers and Local State Authorities in Nondemocratic and Transitional Systems." Studies in Comparative International Development 46, no. 1 (January 20, 2011): 46-69. doi:10.1007/s12116-010-9078-4.

UN DPKO. The United Nations SSR Perspective. New York: United Nations, 2012.

UN Security Council. "From Madness to Hope: The 12-Year War in El Salvador: Report of the Commission on the Truth for El Salvador." United Nations, 1993. http://www.usip.org/sites/default/files/file/ElSalvador-Report.pdf.

- - - . "Interim Report of the Secretary-General on the United Nations Stabilization Mission in Haiti (August 2004).” New York: United Nations, August 30, 2004. http://www.un.org/en/ga/search/view_doc.asp?symbol=S/2004/698. 
- - - "Report of the Secretary-General on the United Nations Stabilization Mission in Haiti (August 2008).” New York: United Nations, August 27, 2008.

- - - . "Report of the Secretary-General on the United Nations Stabilization Mission in Haiti (August 2016).” New York: United Nations, August 31, 2016.

- - - . "Report of the Secretary-General on the United Nations Stabilization Mission in Haiti (February 2010).” New York: United Nations, February 22, 2010.

- - - . "Report of the Secretary-General on the United Nations Stabilization Mission in Haiti (March 2008).” New York: United Nations, March 26, 2008.

- - - . "Report of the Secretary-General on the United Nations Stabilization Mission in Haiti (May 2005).” New York: United Nations, May 13, 2005. http://www.un.org/en/ga/search/view_doc.asp?symbol=S/2005/313.

- - - . "Report of the Secretary-General on the United Nations Stabilization Mission in Haiti (November 2004).” New York: United Nations, November 18, 2004. http://www.un.org/en/ga/search/view_doc.asp?symbol=S/2004/908.

- - - . "Report of the Secretary-General on the United Nations Stabilization Mission in Haiti (September 2009).” New York: United Nations, September 1, 2009. http://www.un.org/en/ga/search/view_doc.asp?symbol=S/2009/439.

- - - . "Report of the Secretary-General Ton the United Nations Stabilization Mission in Haiti (August 2007).” New York: United Nations, August 22, 2007.

- - . "Resolution 940." New York: United Nations, July 31, 1994.

- - -. "Resolution 1529." New York: United Nations, February 29, 2004.

- - - . "Resolution 1542." New York: United Nations, April 30, 2004.

- - - . "Resolution 1608," June 22, 2005.

- - - "Resolution 1702.” New York: United Nations, July 15, 2006.

- - . "Resolution 1743." New York: United Nations, February 5, 2007.

- - - . "Resolution 1780." New York: United Nations, October 15, 2007.

- - - . "Resolution 1944." New York: United Nations, October 14, 2010.

UNDP. "Human Development Report 1994." Oxford University Press, 1994.

United Nations. "Report to the Secretary-General on the United Nations Stabilization Mission in Haiti (March 2014)." United Nations, March 7, 2014.

- - - . "Securing States and Societies: Strengthening the United Nations Comprehensive Support to Security Sector Reform." Report of the SecretaryGeneral A/69/970-S/2013/480. New York: United Nations, August 13, 2013.

United States Institute of Peace. "Public Order." United States Institute of Peace, N.D. http://www.usip.org/guiding-principles-stabilization-and-reconstruction-the-webversion/7-rule-law/public-order.

United States of America. "The National Security Strategy of the United States of America.” Washington, D.C.: The White House, September 2002. 
UNODC. "Intentional Homicide, Count and Rate per 100,000 Population (1995 - 2011)." United Nations Office in Drugs and Crime, 2013.

- - - "Intentional Homicide, Count and Rate per 100,000 Population (2000-2013)." United Nations Office in Drugs and Crime, May 18, 2016.

- - - . "Intentional Homicide Count and Rate per 100,000 Population, by Country/Territory (2000-2012)." United Nations Office on Drugs and Crime, 2013.

- - - " The Eighth United Nations Survey on Crime Trends and the Operations of Criminal Justice Systems (2001 - 2002).” UNODC, March 31, 2005. https://www.unodc.org/unodc/en/data-and-analysis/Eighth-United-NationsSurvey-on-Crime-Trends-and-the-Operations-of-Criminal-Justice-Systems.html.

U.S. Agency for International Development, U.S. Department of Defense, and U.S. Department of State. "Security Sector Reform.” United States, February 2009.

U.S. Department of Defense. "Country Reports on Human Rights Practices for 2009: Haiti." Report. 2009 Country Reports on Human Rights Practices. Washington, D.C.: Department Of State. The Office of Website Management, Bureau of Public Affairs., March 11, 2010. Haitil. http://www.state.gov/j/drl/rls/hrrpt/2009/wha/136116.htm.

U.S. Department of State. "Haiti 2011 Human Rights Report." Country Reports on Human Rights Practices for 2011. Washington, D.C., May 24, 2012. http://www.state.gov/j/drl/rls/hrrpt/2011/wha/186522.htm.

U.S. Department Of State. "Haiti 2015 Human Rights Report." Country Reports on Human Rights Practices for 2015. Washington, D.C.: U.S. Department of State, Bureau of Diplomatic Security, 2016.

http://www.state.gov/j/drl/rls/hrrpt/humanrightsreport/index.htm?year=2015\&dlid $=253021$.

U.S. Overseas Security Advisory Council. "El Salvador: 2006 Crime and Safety Report." Washington, D.C.: U.S. Department of State, Bureau of Diplomatic Security, October 4, 2006.

- - - . "Haiti 2016 Crime \& Safety Report." Washington, D.C.: U.S. Department of State, Bureau of Diplomatic Security, March 1, 2016. https://www.osac.gov/pages/ContentReportDetails.aspx?cid=19193.

USAID. “USAID Central American and Mexico Gang Assessment.” USAID, April 2006. http://pdf.usaid.gov/pdf_docs/Pnadg834.pdf.

Valencia, Roberto. "Decimocuarto Comunicado de Las Pandillas." Crónicas Guanacas, September 20, 2013.

http://cronicasguanacas.blogspot.com/2013/09/decimocuerto-comunicado-de-laspandillas.html.

- - - . "How El Salvador Handed Its Prisons to the Mara Street Gangs." Insight Crime, September 3, 2014. http://www insightcrime.org/news-analysis/how-el-salvadorhanded-its-prisons-to-the-gangs. 
- - - "La Tregua Redefinío El Mapa de Asesinatos En El Salvador." El Faro, March 9, 2015. http://www.salanegra.elfaro.net/es/201503/cronicas/16490/La-Treguaredefini\%C3\%B3-el-mapa-de-asesinatos-de-El-Salvador.htm.

Venkatesh, Sudhir. Off the Books: The Underground Economy of the Urban Poor. First Edition edition. Cambridge, MA: Harvard University Press, 2009.

Visite de Sandra HONORE a Cite Soleil / Marché de La Croix Des Bossales, 2014. https://www.youtube.com/watch?v=t8qbL2up3HY\&feature=youtube_gdata_play er.

Wade, Christine. "El Salvador's Murder Epidemic and the Paradox of Peacebuilding Success." World Politics Review, January 25, 2016. http://www.worldpoliticsreview.com/articles/17762/el-salvador-s-murderepidemic-and-the-paradox-of-peacebuilding-success.

Weber, Max. Economy and Society: An Outline of Interpretive Sociology. Berkeley: University of California Press, 1978.

Wells, Miriam. “'Rising Extortion' Signals Trouble For El Salvador's Gang Truce.” Insight Crime, March 18, 2013. http://www.insightcrime.org/news-briefs/risingextortions-trouble-salvador-gang-truce.

Wiharta, Sharon, Hassan Ahmad, Jean-Yves Haine, Josefina Löfgren, and Tim Randall. "Case Study: Flood and Tropical Storm Jeanne, Haiti, 2004." In The Effectiveness of Foreign Military Assets in Natural Disaster Response. Stockholm, Sweden: Stockholm International Peace Research Institute, 2008.

Winters, Cecilia Ann. "Institution Building in Haiti: An Assessment of the Interim Cooperation Framework 2004-2006." Journal of Human Development 9, no. 2 (July 1, 2008): 283-303. doi:10.1080/14649880802078827.

Wolf, Sonja. "Mano Dura: Gang Suppression in El Salvador." Sustainable Security, March 1, 2011. https://sustainablesecurity.org/2011/03/01/mano-dura-gangsuppression-in-el-salvador/.

- - - . "Policing Crime in El Salvador." NACLA Report on the Americas 45, no. 1 (2012): 43-54.

- - - "Public Security Challenges for El Salvador's First Leftist Government." NACLA Report on the Americas, July 7, 2010. http://nacla.org/news/publicsecurity-challenges-el-salvador\%E2\%80\%99s-first-leftist-government.

- - - "Street Gangs of El Salvador." In Maras: Gang Violence and Security in Central America, edited by Thomas Bruneau, Lucía Dammert, and Elizabeth Skinner, 4369. Austin: University of Texas Press, 2011.

- - - . "The Maras - an Escalating Problem in El Salvador." Latin American Bureau, January 24, 2012. http://lab.org.uk/the-maras-an-escalating-problem-in-elsalvador.

Wood, Elisabeth Jean. Insurgent Collective Action and Civil War in El Salvador. New York: Cambridge University Press, 2003. 
- - - "The Social Processes of Civil War: The Wartime Transformation of Social Networks." Annual Review of Political Science 11, no. 1 (June 2008): 539-61. doi:10.1146/annurev.polisci.8.082103.104832.

World Bank. "Armed Forces Personnel, Total I Data I Table." World Development Indicators, 2015. http://data.worldbank.org/indicator/MS.MIL.TOTL.P1?page=3.

Wörlein, Jan. "De La Militarisation de L'aide Humanitaire À La Humanitarization de La Sécurité. Le Nexus - Sécurité - Développement et Le Cas de La MINUSTAH En Haïti." Université de Montréal, 2015.

Zanotti, Laura. "Cacophonies of Aid, Failed State Building and NGOs in Haiti: Setting the Stage for Disaster, Envisioning the Future." Third World Quarterly 31, no. 5 (2010): 755-71.

Zilberg, Elana. "Fools Banished from the Kingdom: Remapping Geographies of Gang Violence between the Americas (Los Angeles and San Salvador)." American Quarterly 56, no. 3 (September 1, 2004): 759-79.

Zürcher, Christoph. "Conflict, State Fragility and Aid Effectiveness: Insights from Afghanistan." Conflict, Security \& Development 12, no. 5 (December 1, 2012): 461-80. doi:10.1080/14678802.2012.744180. 